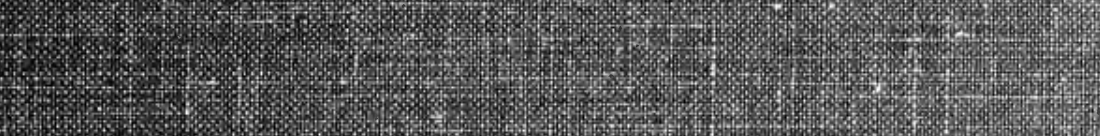

4.

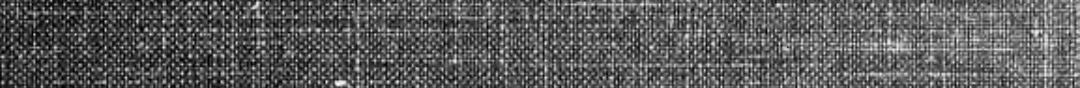

F.

(1)

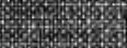

7.7.7.

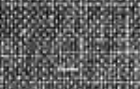

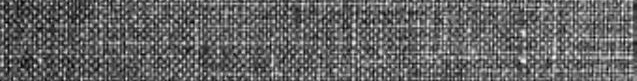

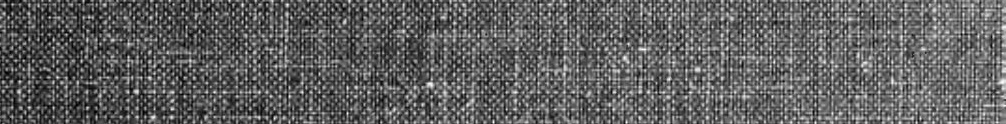

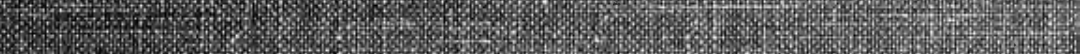

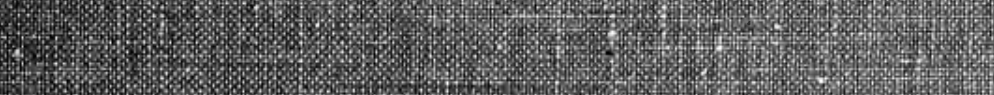

(5)

\begin{tabular}{|c|c|c|c|}
\hline &
\end{tabular}

F.

F

2.

(2)

\%

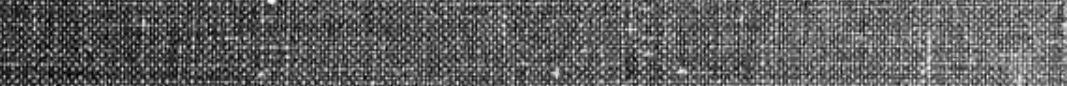
\begin{tabular}{|c|c|c|c|}
\hline & & &
\end{tabular}

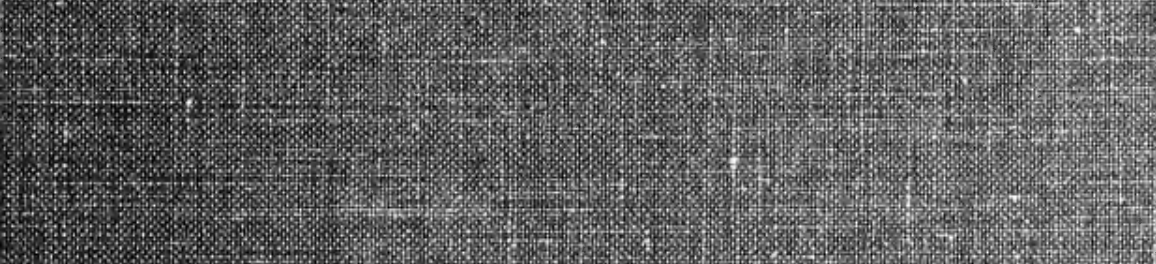

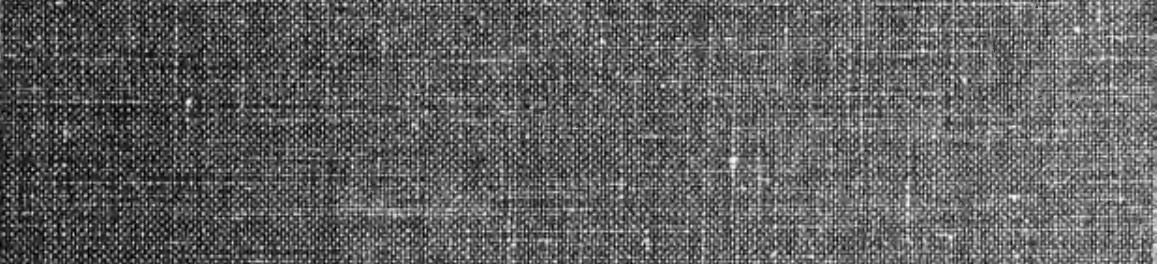

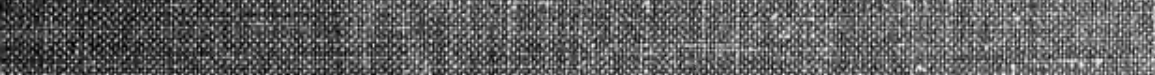

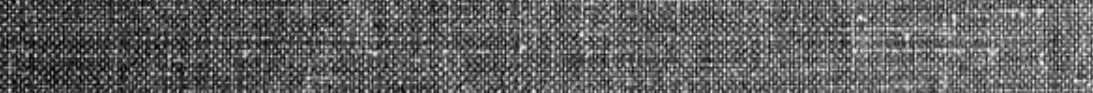

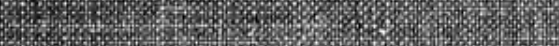




(f)
(1,

造盾:

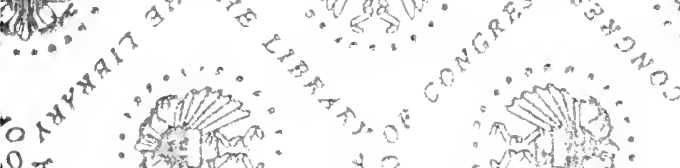

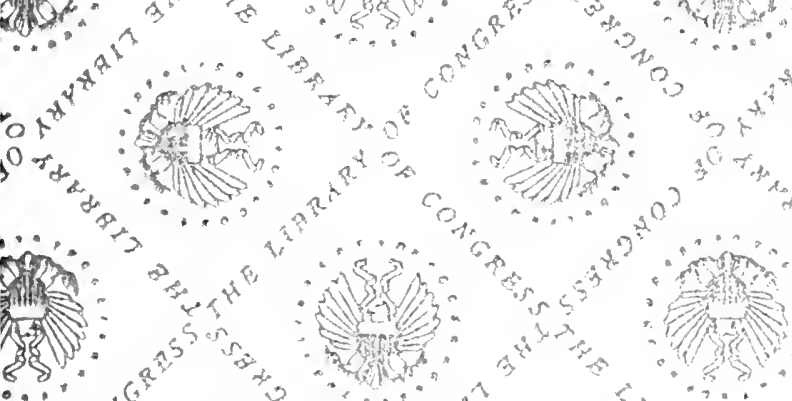

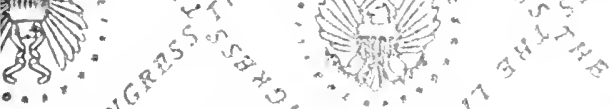

80
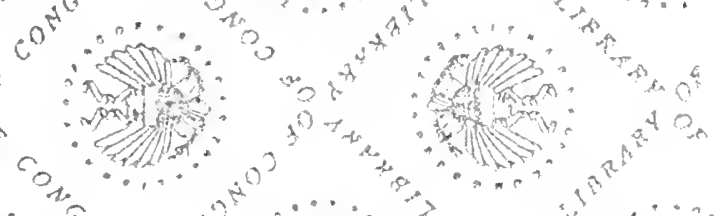

is

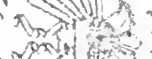

,

min

s.

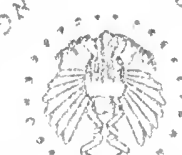

"...

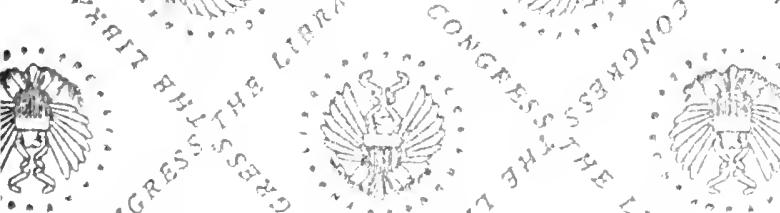

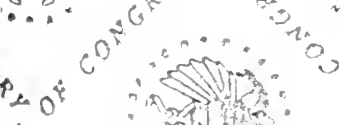

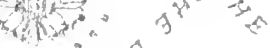

$7^{4} O_{+}$

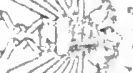

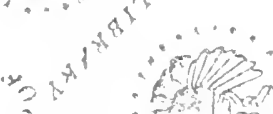

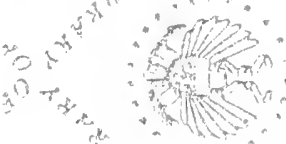

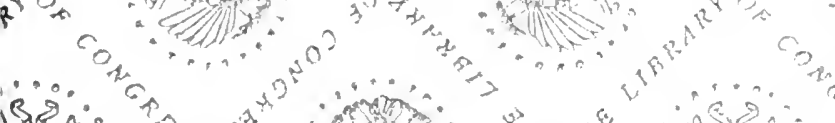

$\therefore$ isto $=$

- ntand 


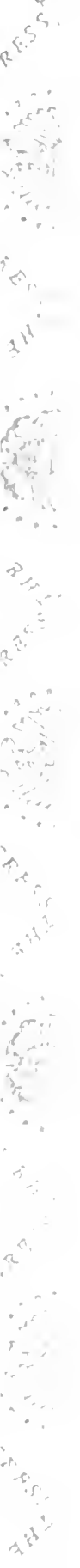



if 


\section{GEORGIA AS A PROPRIETARY PROVINCE}

THE EXECUTION OF A TRUST

BY

JAMES ROSS McCAIN, Ph.D.

Professor of American History

Agnes Scolt College

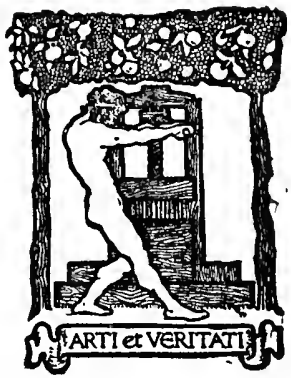

BOSTON: RICHARD G. BADGER TORONTO: THE COPP CLARK CO., LIMITED 
Copyright, 1917, by Richard G. Padger

All Rights Reserved

\section{OCT 101917}

Made in the United States of America

The Gorham Press, Boston, U.S. A.

$$
\begin{aligned}
& \text { (C) } 1:-3944 \\
& 52.06 \text { int }
\end{aligned}
$$




\section{PREFACE}

This work makes no attempt to tell the full story of Georgia under the Trustees. Stevens, Jones, and others have written the general history of the colony so fully that there is no need of repetition. Assuming a reasonable knowledge of this history on the part of the reader, the present study attempts to explain in some detail the institutional organization and development of the province. The subjects treated are those which have been practically neglected by the historians of the state. 'The study has of necessity been made almost exclusively from the original sources; and it is believed by the author that no information on this subject has been untouched. Many of the manuscript materials have never before been available for use by Georgia historians.

The first five chapters of this monograph were printed in 1914 under the title "The Executive in Proprietary Georgia" for presentation to Columbia University as a doctoral dissertation. 'The thorough revision of these chapters and the addition of so much new material make the present publication practically a new work.

Though particular mention can be made of only a few of those who have aided in the prosecution of this study, the author is decply grateful to all who have rendered him service in the matter. Foremost among those to whom gratitude is due, is Professor H. L. Osgood, of Columbia University, whose assistance and advice in gathering material and in organizing it have been invaluable. To Hon. Lucian 
Lamar Knight, Compiler of the Georgia State Records, I am indebted for his cordial aid in providing access to the manuscripts and other source materials in the Capitol. My father, Dr. J. I. McCain, of Erskine College, has been good enough to read the entire manuscript and make helpful suggestions. Finally my wife has given constant encouragement in every stage of the work, and she has rendered special service in the reading of the proof.

The Author.

Agnes Scott College,

Decatur, Georgia,

August 1, 1917. 


\section{CONTENTS}

\section{THE CREATION OF THE TRUST}

Motives for Settling Georgia . . . . . . . . . . . . 17

Relief of the poor . . . . . . . . . . . . . . . . 18

Promotion of English trade _. . . . . . . . . . . . . $\quad$. 19

Erection of barrier province against Spanish and Indians . . . 21

Petition for Establisiment of Corporation . . . . . . . . . 92

First report of the Board of Trade. . . . . . . . . . . . . $\quad 2 Q$

Its second report . . . . . . . . . . . . . . . . . . . . 23

Charter granted . . . . . . . . . . . . . . 24

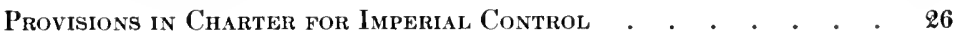

\section{THE PERSONNEL OF THE TRUSTEES}

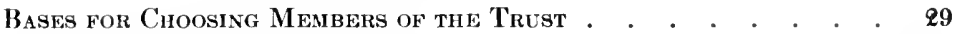

Interest in charitable work . . . . . . . . . . . . . . . . . $\quad$. 29

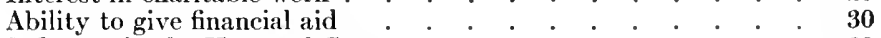

Influence in the House of Commons . . . . . . . . . . . $\quad$. 30

Tabulation of the Attendance of each Member of the Trust on its Meetings . . . . . . . . . . . . . . . . . . . . . 31

Table Silowing the Faithfulness of tile Members of the Common Council of the Trust in their Attendance . . . . . . . . . 35

Record of tile Committee Service of eaci Trustee . . . . . . 38

General Summary Showing the Most Faithful Members in all the Departients of Service . . . . . . . . . . . . . . . . 40

James Vernon: the Most Faitifful Trustee . . . . . . . . 41

John, Lord Viscount Perceval, Later Earl of Egmont . . . . 44

Henry L’Apostre . . . . . . . . . . . . . . . . . . 46

Rev. Samule Smith . . . . . . . . . . . . . . . 47

Thomas Tower . . . . . . . . . . . . . . . . . . . . . 48

Robert Hucks and John Laroche . . . . . . . . . . . . . 49

Rev. Stephen Hales - . . . . . . . . . . . . . . 50

Anthony Ashley Cooper, Fourth Earl of Suaftesbury . . . . 51 
Trustees Faithaul for Short Periods . . . . . . . . . . . 59

Diffeirences Among Members of tile Trust . . . . . . . . . . . $\quad 54$

Few of tile Trustees Rejlly Devoted to the Caise of Goligi $\quad 55$

A Siall Group of Them Worthy of Ilighest Praise . . . . . 56

\section{RELATION OF OGLETIORPE TO GEORGI}

Life of Ogletiorpe Prior to time Focnding of the Colony · • • 57

Did Ie Originate tie Plax of Settling Georgla? . . . . . 60

Activities in Preparing for tile Filest Fixpenition . . . . . . . 62

Motives for Accompanying tile Settlers to Georgia . . . . . 63

Authority in the New Province . . . . . . . . . . . . 64

Not by any means a governor . . . . . . . . . . . . . 64

An attorney with very limited powers . . . . . . . . 65

Labors in Getting tile Colony stateded . . . . . . . . . . 66

Selection of spot for the first town . . . . . . . . . . . . 66

Supervising the surveys and burldings . . . . . . . . . 67

Pacifying the Inrlians . . . . . . . . . . . . . 67

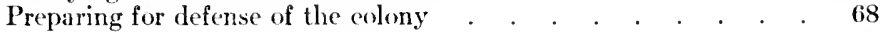

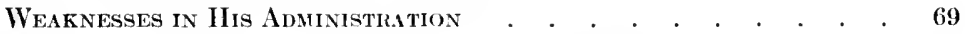

Oglethorpe's Reception on His Return to Exgland . . . . . 70

LAbors Wille in Exgland, 1734-1735 . . . . . . . . . . 71

Powers Still Linited on Second Trip to Georgis . . . . . . 72

New Labors in the Province . . . . . . . . . . . . . . . . 73

His Mistake in Locating Frederica . . . . . . . . . . 74

Intim.tion of Breaci with Trustees abott Expenditures . . $\quad 76$

Treaty witi tile Spanisil at St. Augustine . . . . . . . . . . 76

Second Visit to Exgland, 1736-1738 . . . . . . . . . . . . . . . 77

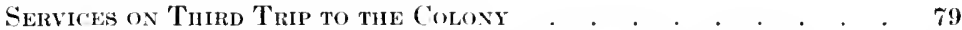

Probing the administration of Thomas Causton in Savannal . . 79

Visit to the Indians at Coweta . . . . . . . . . . 80

Gradual Withorawal of Authority from Oglethompe . • • . 80

Feeling Tilat a Regular Governor for the Colony simould Be Appointed .

Military Services of Ogilethorpe - Explaning Ilis Neglect of

Civil Affilits . . . . . . . . . . . . . 85

Invasion of Florida . . . . . . . . . . . . . . . . . . 86

Repelling the counter attack on Georgia . . . . . . . . . . 86

Promotion and return to England . . . . . . . . . . . 86 
PAGE

Indication of Lack of Harmony Between Oglethorpe and the

Trustees of Georgil

Seriods Disagreement over the Balancing of Trust Accounts . . 91

Summary of Achievements in Relations with Colony . . . . . . 92

Actuated by high motives _. • . • • • • • • • 92

Faihure in South Carolina differences . . . . . . . . . . 99

Mistaken judgment as to legislation . . . . . . . . . . . $\quad 94$

Great suceess in defense . . . . . . . . . • . . . . 94

Trustees themselves largely to blane for failures _ . . . . . $\quad 95$

A governor with large discretionary powers needed . . . . . 96

\section{ORGANIZATION AND AC'TIVITIES OF THE TRUST IN ENGLAND}

General Charter Provisions as to Powers of the Trustees 98

A Common Council to Execute Many of these Functions . . . 100

Provisions for membership . . . . . . . . . . . . . 100

Executive Officers for the General Corporation and for tile

Separation of Powers Between the Corporation and tile Council

Contrary to Expectition, the Counchl Meets less Frequently than the General Organization . . . . . . • . . • . 105

Regularity of Trust Meetings ․ . . . . . . . . . . . 106

The Annual Meeting and its Importance . . . . . . . . 109

Notable Decline of Interest in Attendance on Businegs . . 110

Committen Activities of tile General Corporation • • • . . 111

Work of Comattees in the Common Council . . . . . . . . 113

Struggle to Remain Independent of the Board of Trade • • . 116

Disputes with tile Commissioners of the Custons . • • • . . . 121

Relations witi tile Admiralty Board . • • • . • . . . 122

Long Struggle for Parliamentary Sitpport . • . . . . . . 123

Failure to get the colony in the budget . . . . . . . . 124

Walpole's threatening attitude . . . . • . • . • . . . 125

Efforts to provoke Parliamentary inquiry . * . . . . . . 128

New Ministry unfavorable to Georgia in 1742 . . . . . . . 129

Investigation of colony provoked by its enemies $\quad . \quad$. . . . $\quad$. 130

Trustees justified, but get no money . • • • • • • • . 131

Second decade of Trust less eventful in relation to Parliament . 132 
Proposal to Surrender the Trust to the Crown in 1752

\section{$V$ ORGANIZATION OF THE EXECUTIVE IN GEORGIA}

General Features of British Colonlal Government Fairly Uni-

Trustees Deliberately Depart from tilese Features $\quad . \quad . \quad . \quad 138$

Georgia Unique in its Provincind Organization * . . . . . 139

No Government Provided for Many Parts of tile Colony . . . 141

Local Models Still Followed in 1735 . . . . . . . . . . . 143

Individula Appointees of the Trustees for special Tasks do Most of TIIE EXecutive Work

Dissatisfaction both in England and in Georgia . . . . . . 147

Appointaent of a Secretary to be Resident in Colony . . . . 148

His instructions as to:

Military affairs . . . . . . . . . . . . . . . . . . . 149

Civil concerns . . . . . . . . . . . . . . . . . 150

Religious business . . . . . . . . . . . . . . 150

General matters . . . . . . . . . . . . . . . 151

Organization of the Province into Two Colinties, 1741 . . . . 153

A president and assistants for each county . . . . . . . 154

Nominal powers of the president . . . . . . . . . . 155

President and assistants organized as a Board also limited in power . . . . . . . . . . . 157

The County of Savannah the only one organized under the plan . 158

All Georgia Placed under a single Colonial Governaent for the

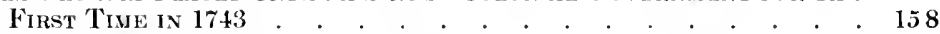

Salaries for all Offtcers notably Simal . . . . . . . . 159

Gradual Increase of Power for the Georgla Officlals . . . . $16_{1}$

Sone Leading Officials in Georgin Affilrs under the Trustees . 162

'Thomas Causton . . . . . . . . . . . . . 163

Henry Parker . . . . . . . . . . . . . . . 164

Thomas Christie . . . . . . . . . . . . . . . 166

Nohle Jones . . . . . . . . . . . . . . . . . . 166

William Stephens . . . . . . . . . . . . . . 167

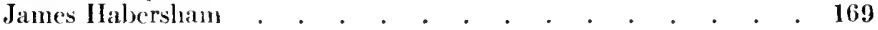

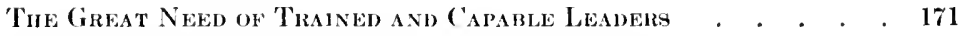

Truestees Partly to Blame for the Failitre of then RepresentATIVES 


\section{LEGISLATIVE HISTORY OF THE PROVINCE}

$1 \mathrm{AGE}$

Full Legislative Power for Twenty-one Years Vested in TrusTEES

The People of tile Colony Allowed no Volce in Making Laws . . 173

No Formal Laws or Rules Adopted for Several Years . . . . 174

Colony at First Controlled by Specific Directions from England for Each Emergency c. . . . . . . . . . . . . .

Three Important Laws Passed in 1735 - the Only Ones for Twenty

Summary of provisions of act regulating Indian trade . . . . 177

Details of the law forbidding the importation and use of rum . . 179

Law prohibiting the use of negro slaves in Georgia . . . . . 180

Other Legislation Suggested, but not Passed . . . . . . . 181

Regulations Controlling Land Tenures. . . . . . . . . 182

Acts Passed by Trustees, but Disapproved by the Board of Trade . 183

Attempts to Modify or Repeal other Acts also Blocked by tife BOARD OF TRADE . . . . . 184

The Weakness Resulting from so few Laws . . . . . . . 187

Dissatisfaction of tile People of Georgla Manifested bx Peti-

No Power Allowed tie Colonists even in Local Matters • . 189

Proposals of Trustees in 1750 to Call an Assembly to Act as an AdVTSORY Body for ONe YeAr ONLY 189

Recommendations as to local needs at Savannah . . . . . 192

Suggestions for improvements in colony as a whole . . . . . 193

Many of the Recommendations of the Assenbly Approved by Trusteres - • • 194

The Assembly Establisied as a Permanent Advisory Body . . . 195

Estrmate of Legislative Activities During the Proprietary Period 196

\section{THE JUDICIARY OF THE COLONY}

Full Judicial Power Granted the Trustees for Only TwentyONE YEARS

Town Court of Savannait Establisied in 1732 . . . . . . . . 199

Town Court for Frederica Establisiled in 1735 . . . . . . . 201

In 1741 Courts More Definitely Established by Counties . . . 203 
Savannah Court Given Appellate Jurisdiction over Whole ProvINCE IN 1743

Court of Frederica and Appelate Power of Savanni Court SusPENDED IN $\mathbf{1 7} 45$

Ffforts to Secure Admilty Courts for Colony Fitile • . . 205

Trustees Tihemselies Active in Judicial Matters . . . . . . 206

Appeal to Privy Council in Case of Joseph Watson . . . . . 209

Justice Usually not Well Admistered in Georgia . . . . . 919

No Lawyers Allowed in Colony . . . . . . . . . . . 213

Difficulty in Securing Fair Jitries . . . . . . . . . . . 215

Attempts of Grand Juries to Exercise too Mlou Power . . . 216

lrregular Methods of Procedtre . . . . . . . . . . . .

Personel of the Early Culrts at Savinnall . . . . . . . 218

Small Amognt of Judiclal Business at Flemerica . . . . . . gel

Salzburghers and Scotch llad Almost no Judiclal Organization. gga

Review uf Judichal Measures . . . . . . . . . . . . . . 285

\section{VHI THE I.ANI) SYSTEM OH GWORGIA}

Section One. Charter Provisionit and Eirly Reguldtons . . . 290

Restrictions on making grants . . . . . . . . . . . 207

Specific regulations of a typieal grant . . . . . . . . . . . 298

Inheritance to be by tail male . . . . . . . . . . . . . 229

No land to be granted in fee simple . . . . . . . . . . . . . 230

First published rules in 1735 . . . . . . . . . . . . . . . . . .

Regulations for adventurers paying their own way . . . . . . 233

Provisions severe in statement, but not in practice. . . . . 234

Section Tro. Struggle fon Better Lixd Regelations . . . . 235

Dissatisfaction pronomneed by 1733 . . . . . . . . . . 235

Concessions granted in 1739 . . . . . . . . . . . . . . . . 237

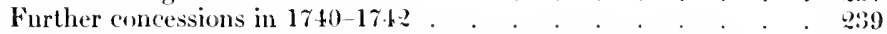

Iouse of Commons urges fee simple temure for adventurers . . Q 2

Law emborlying this advice lost in controvers with law officers of the Crown . . . . . . . . . . . . . . . . . . . . . . . .

All restrictions on land tenures removed in 17.50 . . . . . 243

Section Threc. Forfertures . . . . . . . . . . . . . 214

Many provisions for forfeiture . . . . . . . . . . . 24

Releases frequent . . . . . . . . . . . . . . \&48

Section Four. (Qutt Rents . . . . . . . . . . . . . . . . 249

Four shillings per hundred acres on charity lands . . . . . $\$ 49$

Adventurers charged various rents . . . . . . . . . 850 
Rules of 1735

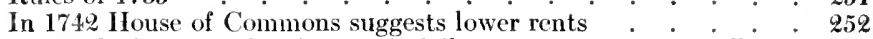

Acts reducing rents for the pcople fail to pass government officials 253

Carteret's interest in Georgia bought by the Crown in 1744 . . 254

No money collected in colony for rents during 1732-1752 . . . 255

Section Five. Macinnery of tiIe Land System . . . . . . . 256

Large trust deeds made to agents for subdivision among colonists going at the expense of the Trust . . . . . . . 257

Steps necessary to obtain a grant except on charity . . . . 258

Officials in Georgia begin to recommend grants . . . . . . 260

Surveyors called forth frequent complaints . . . . . . . . 261

Squatters rare in provinee . . . . . . . . . . . . 263

Section Six. The Size of Land Grants . . . . . . . . , 263

Who could obtain the maximum grant of 500 acres? $. \quad . \quad . \quad 264$

Fear of shortage of land expressed by Trustees . . . . . 265

Charity settlers to get 50 acres each . . . . . . . . . 267

Grants to servants and soldiers when their terms expire - . . 268

Table showing acreage of grants from 1732 to 1741 . . . . . . 269

Applications favorably received $1741-1752$. . . . . . . . . . . 269

Applications rcfused or postponed for the same period . . . . 270

Section Scven. Metiods of Laying Out Land Grants . . . . . 272

Settlements made in communities or towns . . . . . . . 272

Study of Savannah as a type . . . . . . . . . . . . . 272

Comparison and contrast with New England towns . . . . 273

Section Eight. Indian Grants to Trustees . . . . . . . . 275

Gradual extensions of white boundaries . . . . . . . . . 276

Confirmation of grants in 1739 at Coweta .5 .9 .276

Attempts of Bosomworth to get Indian reservations . . . . 278

General Sumary of Land Policy . . . . . . . . . . . 279

\section{EDUCATIONAL PROGRESS IN THE COLONY}

Religious and Secular Instruction . . . . . . . . . . 280

Chrtstopher Ortman at Ebenezer . . . . . . . . . . . 281

Darien and Augusta Left Without Educational Facilities . . . 282

Few Results at Frederica . . . . . . . . . . . . . . . . 283

John Burnside's Petition to Start a "Writing School" at SavanNAH IN 1735 . . . . . . . . . . . . . . . . . . 284

The Indian School Irene 1735 . . . . . . . . . . . . . 284

Delamotte Organizes First Day School in Savannah 1736 . . . 286

Bethesda Orphan Home and School . . . . . . . . . . 287

Whitefield and Habersham co-operate in founding it . . . . 288

Whiteficld's campaign for funds . . . . . . . . 288

Daily program of work at the institution . . . . . . . $\quad . \quad 292$ 
Interruption of work due to Spanish invision . . . . . . 293

Trustees severely reprove Habersham … . . . . . . . . 294

Diffieulties in raising money for the support of work . . . 295

First Free School in Savannah . . . . . . . . . . . . . 297

Peter Joubert an Ineffective Teacher . . . . . . . . . . 299

Edward IIolt Chosen as a Permanent Teacher 1749 . . . . . . 300

Savandah Schools Suspended . . . . . . . . . . . . 301

Summary of Results . . . . . . . . . . . . . . . 302

\section{$\mathrm{X}$ RELIGIOUS HISTORY OF FARLY GEORGIA}

Missionary Societies in Great Britain Dofng Work in tie Colony 303

Relation of the Bishop of London to Georgia . . . . . . . 306

Trustees Composed of botil Dissenters and Members of the EstabLished Church . . . . . . . . . . . . . . . . 308

Worship of Established Church Only ONe to Be Supported by tue Trustees Themselves . . . . . . . . . . . . . . . 309

Rev. Henry Herbert a Temporary Supply at Savannah . . . . 309

Rev. Samuel Quincy Unsuccessful in Most Respects . . . . . 310

Rev. Joiln Wesley at Savannail as Church of England Priest • . 311

Ilis love affair . . . . . . . . . . . . . . . 312

Proseeution by William Williamson . . . . . . . . . . . . 313

Difficulty in getting trial . . . . . . . . . . . . . . 315

Leaves eolony . . . . . . . . . . . . . . . . 315

Unhappy Experiences of Rev. Charles Wesley at Frederica . . 316

Work of Rev. George Whitefield . . . . . . . . . . . 317

Interest aroused in orphanage . . . . . . . . . . . . . . . . . 318

Resigns pastorate at Savannah $\quad . \quad$. . . . . . . . . . . 319

Pastoral Work of Rev. William Norris . . . . . . . . . 320

Rev. Christopher Orton . . . . . . . . . . . . . . 322

Rev. Thomas Bosomworth, the Worst Troeblemaken in the Colony 322

Long and Fruitful Labors of Rev. Bartholomew Zovberbuher . 324

Mission at Augutsta under Rev. Jonathan Copp . . . . . . 326

Chaplains of the Reginent . . . . . . . . . . . . . 327

Presbyterhan Work in the Colony . . . . . . . . . . 328

Moraviax Settlements Only Temporary . . . , , , . . . 329 
Jewish Organization in Province . . . . . . . . . . . . 332

Salzburgher Settlements ANd Work . . . . . . . . . . . . 333

Settlement at Ebenezer .

Work of Rev. John Martin Bolzius and assistants . . . . . 335

Reasons for the success of their work . . . . . . . . . 336

Expenditures of Trustees for Religious Work . . . . . . 337

Church Buildings in Georgia . . . . . . . . . . . 338

Summary of Religious Work in the Province . . . . . . . . 341

BIBLIOGRAPHY . . . . . . . . . . . . . . . . 343

INDEX . . . . . . . . . . . . . . . . . . 351 

GEORGIA AS A PROPRIETARY PROVINCE:

THE EXECU'TION OF A TRUST 



\title{
Georgia as a Proprietary Province: the Execution of a Trust
}

\author{
CHAPTER I \\ THE CREATION OF THE TRUST
}

THE charter creating a corporation to establish the 1 province of Georgia was granted in 1732. It had been more than a hundred years since a corporation for colonizing purposes had been organized in England; and it had been more than fifty years since a colony had been established by English people in America. The wild dreams of untold wealth in America that stimulated colonization in the early part of the seventeenth century had long before been dissipated; religious persecution in England was not so severe that any sect or creed felt it necessary to seek an asylum in the new world; the experience of the proprietors in Carolina had proved that colonization was not financially profitable. All the motives which had inspired the founding of the other colonies seemed to be lacking. What, then, were the causes leading to the establishment of the thirteenth English colony within the present limits of the United States?

The charter itself states with sufficient clearness the three principal objects of the province. These were (1) the relief of poor subjects who through misfortune and want of employment were reduced to great necessity; (2) the in- 
crease of the trade, navigation, and wealth of the realm; and (3) the establishment of a barrier for the defence of South Carolina and the provinces further north against the ravages of the Indians. ${ }^{1}$ It is not necessary to give any extensive account of the reasons for pressing these purposes at that particular time, nor is it worth while to pursue in detail the methods by which it was proposed that the province should accomplish its objects. A few general statements, such as were set forth at that time by the sponsors of the movement, will indicate in outline the plans for the colony.

It was not the purpose of the founders of Georgia to relieve indiscriminately the poor, but rather those of reputable families and of liberal, or at least easy, education. There were multitudes of the poor; according to the writers of the time, four thousand per year were committed to prison for debt alone in the one city of London." Very many of the victims belonged to the class that the new colony was intended to relieve. Some of them had been undone by guardians, some by lawsuits, some by accidents of commerce, some by stocks and bubbles, and some by suretyships; but they all suffered alike, being either a burden to their friends or objects of harsh treatment at the hands of jailers. It was thought that such people might aid themselves and at the same time develop a new province which might be useful in many ways. ${ }^{3}$ Arguments both from the humanitarian and from the economic viewpoints were urged in favor of the project; but the larger part of the stress was put on the economic basis for the effort. For instance, figures were

${ }^{1}$ Colonial Records of Georgia (Cited as C. R.) I: 11.

${ }^{2}$ Reasons for Establishing, Georgia Historical Collections (Cited as G. H. C.) I: 216.

${ }^{3}$ New and Accurate Account, G. H. C. I: 56. 
brought forward to show that it took two thousand pounds to support a hundred families in London, while families of the class that would be sent to Georgia could earn only one thousand pounds; so that their support entailed a loss of a thousand pounds per year on the public. It was estimated that in Georgia these liundred families ought to earn six thousand pounds, clearing four thousand pounds with which to buy English merchandise. ${ }^{*}$ While the economic arguments received the most stress before the public, it was probably the humanitarian motives that gave the first impulse to the plan for starting the colony. So far as it can be ascertained, the movement took definite shape immediately after certain prison investigations that revealed the wretchedness and cruelty suffered by those who were imprisoned for debt. The sequence of time is suggestive of the probable relations of cause and effect between the investigation of the misery and the efforts to relieve it. This probability is strengthened by the fact that several members of the investigating committee, notably James Oglethorpe, were prominently interested in founding the now colony.

The project of founding Georgia came in the midst of the Walpole era. During this period, nearly all of England's energies were directed to the expansion of her trade and the development of manufactures. The idea that the balance of trade must be favorable to a nation in order to be profitable was generally accepted without question; and there was an increasing desire to have the colonies produce raw materials for the manufactories of the realm. In view of these facts, it is not strange that much stress was laid on the possibilities of Georgia for increasing the trade and wealth of England. It was pointed out that France, Spain

\footnotetext{
${ }^{4} \mathrm{New}$ and $\Lambda$ ccurate $\Lambda$ ccount, G. H. C. I: 6?.
} 
and Portugal were promoting and enlarging settlements abroad with unusual industry and success; but it was thought that none of these would compare with Georgia in natural resources.

Since the silkworm mulber'y was indigenous to the province, and since a good quality of silk had already been produced in South Carolina, it was confidently believed that the finest quality of raw silk could readily be produced in Georgia, and it was estimated that the five hundred thousand pounds per annum lost in the balance of trade in this article could be saved. Moreover, the raw material sent from Georgia to England would give employment the whole year round to twenty thousand persons who would be required for its manufacture. It was even hoped that Georgia might enable England to become an exporter of silk, since both land and nulberry leaves would be free in the new colony, and since the cost of production would thus be cheaper than in competing countries."

Georgia was also thought especially adapted to the raising of flax, hemp, and potash, of which products England annually imported from Russia alone the value of more than one hundred and fifty thousand pounds. All this could be saved, it was urged, in the balance of trade by importation from the new colony. Furthermore, the importation from Russia was largely of manufactured goods, while that of the raw goods from Georgia would again encourage home manufactures and so employ more workers. 'Thus help could reach as many poor people who remained in England as actually went over to settle in America.

Since the new colony would be in about the same latitude as Madeira, the proper care and application would result in producing wine in sufficient quantities for both the

${ }^{\circ}$ Reasons for Establishing, G. H. C. I : 210. 
plantations and the realm. Besides the products specified in detail, it was thought that indigo, cochineal, dyeing woods, and drugs of various kinds could be produced in the province. None of these products would compete with those of the realm or of the other plantations; and none would require very severe labor, for which the indigent people of the cities would not be fitted. ${ }^{6}$ The various arguments for the founding of the colony form an excellent commentary on the whole policy of England regarding her commercial and industrial relations to her colonies.

The idea of establishing a barrier province for the protection of South Carolina and the northern provinces arose from the many troubles that had been coming from time to time on the frontiers, especially along the Savannah River. There had been wars with the Spanish in 1686 and in 17031706 ; and the terrible Yemassee war occurred in 1715 . In 1727 the Yemassees were once again threatening to go on the warpath. Numerous frontier defences had been maintained from time to time; but the principal one, Fort King George, on the Altamaha, had been burned in 1726; and so there was no adequate defence from that quarter for South Carolina. ${ }^{7}$ It was thought that Georgia would be a protection because of the rapid growth that was expected of it and also because the people were to be arranged in towns or settlements in the nature of garrisons. As South Carolina was weakened from the standpoint of defence by her slave population, it was expected that negroes would be forbidden in the new settlement.

Actuated by these principal objects, though with others of less import also in mind, the little group of persons interested in the enterprise memorialized the Privy Council for

- Ibid., 212.

${ }^{7}$ Smith 171, 208-209. 
the privilege of carrying on the work. 'The petition set forth the willingness of the petitioners to raise the money neessary to relieve the poor and to transport them to their new homes. In fact they were willing to take entire charge of the founding and support of the province. They requested a grant of land to the south of the Savannah River in South Carolina, together with such powers as might be necessary to carry out the details of the scheme. They requested also the right to purchase and hold lands of inheritance in Great Britain to the value of a thousand pounds. The name suggested by them for the organization to be created was "The Corporation for Establishing Charitable Colonies in America." 'This memorial was presented on September 17, 1730; and it was immediately referred to a committee of the Council for investigation. ${ }^{8}$

As was usual in such cases, the committee of the Council referred the petition to the Lords Commissioners for 'Trade and Plantations, commonly called the Board of Trade, in order to get a report as to the legal questions that might be involved and as to the expediency of granting the petition. The petition was referred to the Board of Trade on November 23, 1730, and, after consulting the law officers of the Crown as to the legality of the charter, the Board made its first report within a month, on December 17, 1730. The unusual promptness with which the matter was decided indicates that there was a general unanimity of opinion in regard to the enterprise. 'The report approved the petition presented and recommended that the tract of land between the Savannah and Altamaha rivers with the islands adjacent, be granted to the petitioners in trust, an annual quitrent of four shillings per hundred acres being paid by the trustees for all the land which they should grant to

${ }^{8} \Lambda$ merica and West Indies (Cited A. W. I.) XXV:322. 
others. A register of all lands so granted must be kept. The tract of land mentioned, being entirely inhabited by Indians, was to be a separate colony. Though independent in its civil and military laws, its militia were to remain in the hands of the King and the dominion of the Crown was to prevail. Officers were to be chosen by the corporation composed of Trustees subject to the approval of his Majesty, and the corporation was to issue commissions under its common seal. Laws were to be made by the corporation and submitted to the King for approval. The person superintending the colony was to take over and receive instructions similar to those taken and received by the governors at the time. ${ }^{9}$

This report was not entirely satisfactory to the promoters of the enterprise, and a conference between them and the conmittee of the Privy Conncil was held on January $12,1731,{ }^{10}$ as a result of which the matter was again referred to the Board of Trade for further consideration. The founders of the colony desired larger powers than had been proposed in the report to Council, and on January 14 the Board reported a second time to the effect that there would be no inconvenience in granting the request of the petitioners. Accordingly, it was recommended that they be allowed to constitute courts of record and other courts under their common seal in the name of the King, and that they also for the period of twenty-one years have the power to appoint and displace all civil and military officers in the district. In addition, it was recommended that such general powers should be granted the petitioners as might "be

${ }^{9}$ Colonial Office (Cited C. O.) V: 401, S. C. Entry Book: 8.

10 The sources on which this work is based frequently use the "old style" of reckoning time; but the dates given herein correspond throughout to present usage in that respect. 
necessary for the support and defence of said colony." 11

On January 18, 1731, the committee of the Council agreed that the Attorney and Solicitor General should prepare a draft of a charter. 'Ten days later the report of the committee was approved by the Privy Council and a formal order was issued for the preparation of the charter by the law officers of the Crown. ${ }^{12}$

The draft of the charter was reported by the Attorney and Solicitor General on August 11, 1731, and the next day it was referred to the committee of the Privy Council for their final approval. In order to have the boundaries of the province determined with more accuracy, the Board of Trade was again asked for alvice; and it was not until January 19, 1732, that the committee finally agreed to lay the charter before the King for his approval. This was given by him in Council on January 2\%, 1732, and the Secretary of State was ordered to prepare a warrant for it to pass the Great Seal. This warrant was duly issued and signed, and on June 9,1732 , the final step in the issuance of the charter was completed with its passing the Great Seal. ${ }^{13}$

'The granting of such a charter was in a measure a reversion to type. It has been noted that more than a hundred years had elapsed since a corporation resident in England had been chartered for the purpose of colonization, but it was through corporations in the nature of trading companies that British colonization was first successfully achieved within the present limits of the United States. Virginia, the first of the colonies, was the proprietary province of a corporation just as was Georgia, the last of the thirteen to be settled. Only two other corporations had

${ }^{11}$ C. O. V : 401, S. C. Entry Book: 15.

${ }^{12} \Lambda$. W. I. XXV: 322.

${ }^{13}$ Ibid., 323. 
been formed for the purpose of colonizing America, and they, like the London company, were organized prior to 1630. Individual proprietorships had been established, and in the case of Carolina eight men had been associated for the purpose of founding a colony ; but apparently the interest in colonization had not been wide-spread enough in England from 1630 to 1730 to call for the organization of a company or corporation. The settlement of Georgia enlisted the interest and the aid of a larger number of people than that of any other English settlement.

Since the charter was granted fifty years later than that of any other British colony, it is interesting to note the effect of experiments with the colonies on the terms of the Georgia charter. Since the establishment of Pennsylvania in 1681, there had been marked efforts on the part of the British goverument to increase imperial control in America, and there was a strong tendency to substitute royal provinces for those of proprietary or corporate nature. ${ }^{14}$ In its first report, the Board of Trade showed several tendencies in this direction. The land was not granted outright to the petitioners, but they were to be tenants of so much as they might occupy, paying therefor to the King the rather heavy quitrent of four sbillings proclamation money per hundred acres. Careful registers were to be kept to ascertain the King's rights in the matter. Of greater importance, was the provision in the report requiring that officers be approved by the King, and that all laws be submitted to him for approval. Moreover, a great deal of imperial control was secured by the requirement that officials in the new colony must take and receive instructions such as were given to the royal governors in the American provinces.

As the charter was finally issued, there were numerous ${ }^{14}$ Osgood III : 23. 
provisions also for imperial control. The most renarkable one was that limiting the powers of government bestowed on the founders of Georgia to a period of twenty-one years. The petitioners had sought greater powers of appointing and removing officers and of establishing courts, and the request was granted only on the condition of this time limitation. Formal laws must be approved by the King, but regulations and orders to fit special occasions could be given without approval. The power of making laws was also limited to a period of twenty-one years, and no law could become effective until actually approved. Even in the matter of appointing officers, there were two restrictions in favor of royal control. 'The Crown reserved the right to appoint all those who should be chosen to collect the King's revenue. Moreover, the person appointed to be governor in the colony must have the approval of the $\mathrm{King}$, and must qualify himself properly by taking oaths and giving security to obey the acts of Parliament relating to trade and navigation and to obey instructions sent him pursuant to said acts. He was not bound, however, to obey general instructions. 'The supervision of the British government over the financial managcment of the colony was secured by the requirement that an ammual account of all moneys received and expended be presented in writing to two officials of the home government. It was further stipulated that from time to time accounts of the progress of the colony should be given to the secretaries of state and to the Board of Trade.

Having secured this charter which put them under the supervision of the Finglish government and yet gave them a considerable anount of freedom in moulding the plans for the colony, the petitioners at once proceeded with the enterprise. 'itheir efforts, extending over a period of twenty years, resulted in the establishment of the proprietary prov- 
ince of Georgia. The institutional development of this last English colony in America was peculiar in many respects, affording several points of contrast with that of the older colonies. It is impossible in a brief work to deal with all phases of this development; but it is here intended to treat in some detail a few of the problems which confronted the grantees of the charter of Georgia in the execution of the Trust which had been committed to them. 


\section{CHAPTER II}

THE PERSONNEL OF TIE TRUSTEES

THE clarter provided for a corporation to be known 1 as "The Trustees for Establishing the Colony of Georgia in America." The name had been changed so as to be more definite than that at first suggested by Oglethorpe to the Board of Trade, and it is not known who proposed the one finally adopted. Twenty-one men were designated by name as the original members of the corporation; but the membership was not limited to that number. The Trust was an open corporation like the London Company and the Massachusetts Bay Company, whereas the New England Council had been a closed corporation. The difference between the two kinds of companies was that open corporations could indefinitely increase their nembership, while closed ones maintained a definite number of members. It was a wise provision of the charter, since it allowed the Trustees to associate with them as many good and influential men as they might be able to interest in their enterprise. From the nature of the undertaking, it was not to be expected that many men would seek membership in the Trust; only those who were willing to do hard work without remuneration could be induced to join in carrying on the settling and support of the colony. In addition to the twenty-one Trustces named in the charter, fifty others were elected to office during the twenty years of the corporation's existence. 'Twenty-six of these were 
chosen during the first two years of the Trust, while the remaining twenty-four were scattered somewhat uniformly through the last eighteen years. This inequality of distribution in the adding of members is readily explained by the great amount of interest in the colony and enthusiasm for its development that were especially manifest during the years 1733 and 1734.

The Trustees named in the charter did not belong to any one profession or rank in society, though all were gentlemen. Interest in the charitable work proposed seems to have been the general basis of appointment. Five of the twenty-one members were ministers of the gospel, all of the Church of England. 'Ten were members of the House of Commons. Two held seats in the House of Lords. One was a commissioner of the excise, another was a philanthropist noted for his work in establishing and supporting hospitals, still another was clerk in the South Sea House, while the last was a country gentleman. None of the men were distinguished nobles or noted political leaders at the time, nor were they of such wealth that they would be able to carry on the work by their own financial contributions, in fact the records for the whole twenty years of the Trust show gifts from these twenty-one members of only about two hundred and twenty-five pounds. ${ }^{1}$

In the choice of members at the annual meeting of 1733 , it would seem that interest in the financial progress of the colony had weight. Of the seventeen Trustees chosen on that occasion, twelve had shown their personal interest either by making contributions in money or by securing commissions to solicit funds from others for the purposes of the charter. Of the five who do not appear to have been thus interested, one was a member of the House of Lords, three ${ }^{1}$ C. R. III: 1-208. 
of the House of Commons, and the last was a country gentleman.

If financial support was the basis of choice in 1733, it did not eontinue to be, for the next year nine 'Trustees were chosen, none of whom had contributed to the eolony or had tried to get others to do so, though six of them made contributions shortly after their election. Four of them were members of the House of Commons, one was of the House of Lords, another was a clergyman, still another was an eminent lawyer, while about the remaining two very little is known. 'The next 'Trustee, who was ehosen in 173\%, was undoubtedly selected on aceount of his great financial assistance. He had given a thousand pounds from a trust fund in his possession for the development of Georgia, this sum being mueh in excess of the combined contributions of all the other 'Trustees during the proprietary period.'

Between the years 1738 and 1743 inclusive there were elected thirteen members of the corporation, and all of these were members of Parliament. There hat been a strong tendency heretofore to choose members from those who could be useful in securing the support of Parliament, and as the support became more doubtful it is not surprising that members of the House of Commons would make the most acceptable Trustees.

Of the ten members chosen during the last decade of the 'Trust, six were members of Parliament, one a elergyman, another was Lord Mayor of London, still another was a merchant, while nothing is known of the remaining one. ${ }^{3}$

Of the seventy-one ${ }^{4}$ Trustees, eleven never qualified by 2 C. R. I : 273-275.

${ }^{3}$ Stevens I: 4.7-175.

${ }^{4} \mathrm{Jones}$, Stevens, and others give lists of seventy-two members of the 'lrust, but they overlook the faet that Robert Kendall, Esq., and Sir Robert Cater were two names for the same man. C. R. I: 28. 
attending a single meeting and seven others attended only three meetings or less, so that the active membership of the Trust was only fifty-three, and it must not be supposed that all of these did much work either in attending meetings or in looking after the details of the colony. In view of the large number who were indifferent, we can understand why the average attendance was so small at both corporation and Common Council meetings. For the purpose of our study, the activity of a man in Georgia affairs and his general usefulness to the Trust are of more importance than the facts of lis personal or private life. Some of those elected members of the corporation were in many respects very noted and influential men, and yet their participation in the business of the Trust was so slight that they do not merit individual attention in studying the personnel of the working members of the board. The following table will indicate those who were most diligent in attending to the duties which devolved on the members of the corporation:

ATTENDANCE OF MEMBERS ON THE MEETINGS OF THE TRUSTEES FOR ESTABIISHING THE COLONY OF GEORGIA

IN AMERICA, 1732-1752.

\begin{tabular}{|c|c|c|c|}
\hline Name & Chosen & $\begin{array}{l}\text { Meetings } \\
\text { attended }\end{array}$ & $\begin{array}{l}\text { Meetings } \\
\text { held } \\
\text { during } \\
\text { member- } \\
\text { ship }\end{array}$ \\
\hline $\begin{array}{l}\text { iscount Perceval. } \\
\text { rl of Egmont.) }\end{array}$ & - 1732 & 343 & 450 \\
\hline Digby, Esq.... & 1732 & 97 & 512 \\
\hline $\begin{array}{l}\text { nter, Esq....... } \\
\text { d Carpenter.) }\end{array}$ & 1732 & 70 & 463 \\
\hline rpe, Esq..... & 1732 & 147 & 512 \\
\hline cote, Esq..... & 1732 & 84 & 512 \\
\hline
\end{tabular}




\section{Name}

Thomas 'Towers, Esq....... 1732

Robert More, Esq.......... 1782

Robert Hucks, Esq. ........ 1732

Rogers Holland, Esq........ 1732

William Sloper, Esq........ 1732

Francis Eyles, Esq. . . . . . . . 1732

John Laroche, Esq. . . . . . . . . 1732

Hon. James Vernon, Esq. . . . . 1732

William Belitha, Esq....... 1732

Rev. Stephen Hales. D.D. . . . 1732

Rev. John Burton ......... 1732

Rev. Richard Bundy, D.D. . . . 1782

Rev. Arthur Bedford ...... 1739

Rev. Samuel Smith ........ 1732

Mr. Adan Anderson. . . . . . . 1732

Mr.' Thomas Coram . . . . . . . 1732

James Earl of Derby. . . . . . . 1733

Anthony Ashley Earl of Shaftes-

bury . . . . . . . . 1733

John Lord Viscount 'Tyrconnel. 1733

James Lord Viscount Limerick. 1733

James Lord D'Arey . . . . . . . . 1733

IIon. Richard Chandler, Esq. . 1733

Thomas Frederick, Esq. . . . . . 1733

I Ienry L'Apostre, Esq. . . . . . . 1733

William Heathcote, Esq. . . . . . 1733

(Later Sir Wm. Heathcote, Bart.)

Robert Kondall, Esq........ . 1733

(Later Sir Robert Cater.)
Meetings held during

Meetings attended

193

39

187

87

36

26

161

394

18

152

46

81

36

352

129

129

None membership

512 512 423

512 388 512 512 512 512 512 512 274 423 512 512 494 476

138

476

102

476

476

None

64

61

476

30

320

294

125

476

476

29

273 


\section{Name Chosen}

John Page, Esq.......... 1733

William Hanbury, Esq. . . . . . 1733

Erasmus Phillips, Esq....... 1733

(Later Sir E. Phillips, Bart.)

Christopher Towers, Esq..... 1733

Sir John Gonson, Knight. . . . . 1733

George Tyrer, Esq. . . . . . . 1733

John White, Esq. . . . . . . . 1733

Rev. Thomas Rundle, D.D.... 1734

(Later Lord Bishop of Londonderry.)

Hon. William Talbot, Esq..... 1734

(Later Lord Talbot.)

Richard Coope, Esq. ........ 1734

William Wollaston, Esq...... 1734

Hon. Robert Eyre, Esq...... 1734

Thomas Archer, Esq....... 1734

(Later Lord Archer.)

Henry Archer, Esq. . . . . . . . . 1734

Robert Tracy, Esq........ 1794

Francis Wollaston, Esq...... 1794

Sir Jacob Des Bouverie, Bart. . 1737

(Later Lord Viscount Folkstone.)

Sir Harry Gough, Bart...... 1738

Sir Roger Burgoyne, Bart. . . . 1738

Lord Sidney Beauclerk....... 1739

Hon. Henry Bathurst, Esq.... 1741

Hon. Philip Perceval, Esq..... 1741 John Frederick, Esq........ 1741

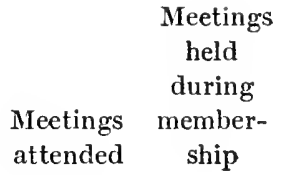

16

476

1476

$1 \quad 4 \% 6$

$23 \quad 476$

$6 \quad 476$

None $\quad 476$

$38 \quad 4 \% 6$

$4 \quad 272$

$8 \quad 412$

None 412

$2 \quad 412$

$63 \quad 412$

$39 \quad 412$

$62 \quad 412$

$57 \quad 412$

None 412

4.283

$10 \quad 238$

$1 \quad 238$

$19 \quad 101$

$8 \quad 165$

$33 \quad 116$

$10 \quad 165$ 
Nanie

Chosen

Meetings

Meetings held during attended membership

Hon. Alexander Hume Camp-

bell, Esq........... 1742

None

146

Sir John Barrington, Bart.... 1742

Samuel Tuffnell, Esq........ 1742

Henry Calthrope, Esq....... 1742

(Later Sir Henry Calthrope.)

John Phillips, Esq........ 1743

(Later Sir John Phillips, Bart.)

Velters Cornewall, Esq....... 1743

John Wright, Esq.......... 1743

Rev. Thomas Wilson, D.D.... 1745

Francis Cokayne, Esq....... 1747

Samuel Lloyd, Esq......... 1747

Hon. John Earl of Egmont.. 1749

Anthony Ewer, Esq........ 1749

Edward Hooper, Esq........ 1749

16

Sir John Cust, Bart. . . . . . . 1749

Slingsby Bethel, Esq....... 1749

Stephen Theodore Jansen, Esq. 1749

Richard Cavendish .........

None

None

In addition to the regular members listed above, there were chosen on March 19, 1747, two corresponding members of the Trust for the service of Salzburghers and other Germans who might be inclined to go to Georgia. These were Mr. Chretien Von Munch and Rev. Samuel Urlsperger of Augsburgh. They never attended any meetings of the Trust but they frequently gave information and advice through 
letters to the Trustees. ${ }^{5}$

Since the Common Council of the Trustees was a closed board with a limited membership and since it was necessary for it to have eight members present in order to do business, it was more important that those holding office in it be selected from active and interested persons than that such should be chosen for the corporation only. There were in all forty-eight members of the Common Council appointed or selected. Of this number, two never accepted the office to which they were elected, so that only forty-six actually took the oath which inaugurated them into service. Six members served during the whole period of proprietary control, and two others served from the completion of the first Council on March 15, 1733, to the end of the period. Since the duties of a Common Councilman were in many respects more arduous than those of an ordinary member of the corporation, it is worth while to tabulate the faithfulness of its members.

ATtendance OF THE MEMBERS OF THE COMMON COUNCIL ON its MEETINGs, 1732-1752

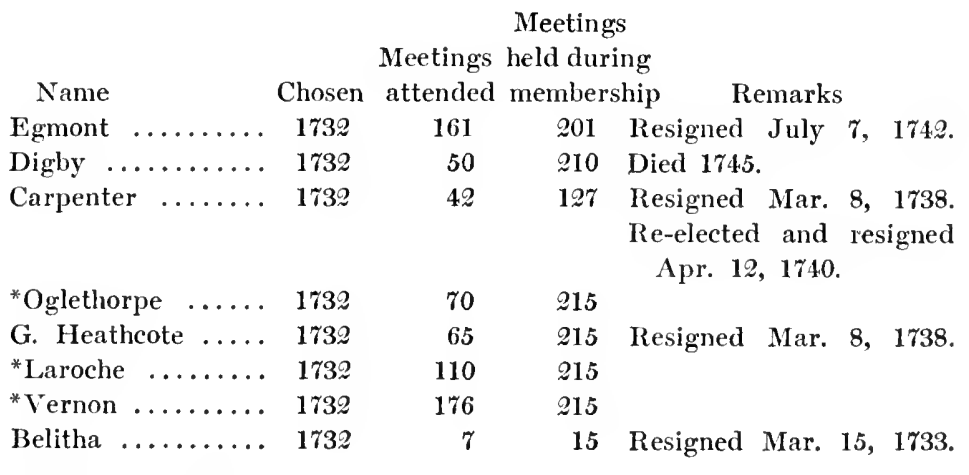

${ }^{5}$ C. R. I: 499. 


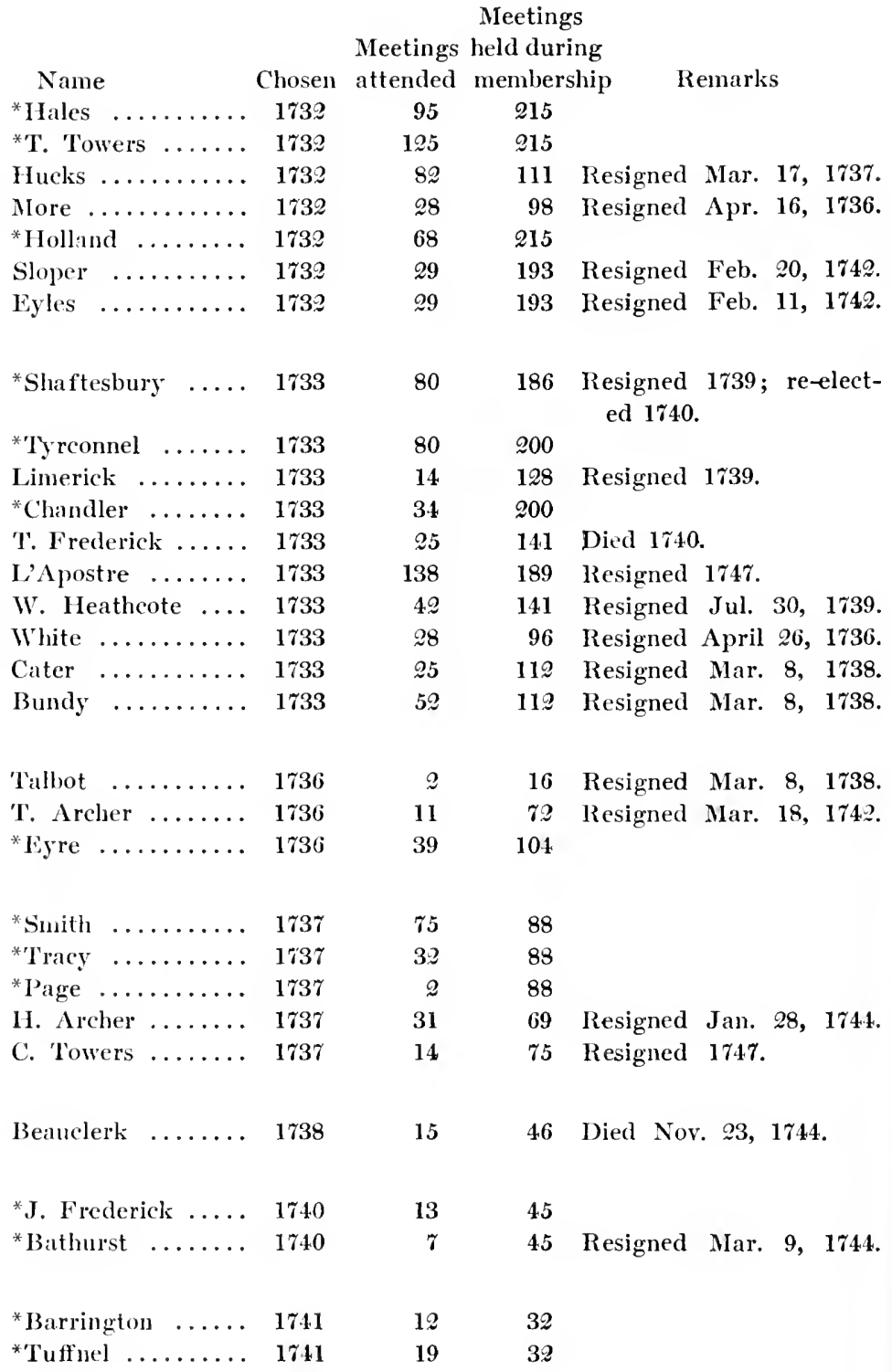




\section{Meetings \\ Meetings held during}

Name Chosen attended membership Remarks

${ }^{*}$ Phillips $\ldots \ldots \ldots .1742$

P. Perceval ..... 1743

${ }^{*}$ Cornewall $\ldots \ldots \ldots \quad 1743$

10

None

25

8 Died $174 \%$.

6

19

Bouverie ....... $1744 \quad$ None

${ }^{*}$ Wilson $\ldots \ldots \ldots \ldots \quad 1746$

${ }^{*}$ Lloyd ......... 1749

${ }^{*}$ Hooper ....... 1749

${ }^{*}$ Ewer $\ldots \ldots \ldots \ldots .1749$

*Cavendish

$6 \quad 13$

None

17 (Resigned ?)

13

$\begin{array}{ll}9 & 9 \\ 6 & 9 \\ 8 & 9\end{array}$

1 ?

* Those whose names are thus marked above formed the Common Council when the charter was surrendered in 1752. The minutes of the Trustees are not quite complete as to the changes made during the last few years and it is not certain when Cavendish was chosen to the Council or whether Bouverie ever resigned from the body or not.

Besides attending the meetings of the corporation and the Common Council, the more active Trustees frequently had duties to perform on some of the permanent or special committees which were so frequently employed by both bodies. Although service on the committees was very often assigned to any three or more of the members, it usually devolved on a very few persons who were willing to sacrifice their time for the good of the colony. The various journals and minutes which describe the work of the committees frequently fail to indicate the individuals who composed the conmittees, but sufficient information may be gleaned from them to show with reasonable accuracy the members both of the corporation and of the Common Council who were 
most prominent in this work. The general results are tabulated below:

COMMITTEE SERVICE OF THE CORPORATION AND OF THE COMMON COUNCIL OF TIE TRUSTEES FOR ESTABLISHING THE COLONY OF GEORGIA IN AMERICA

\begin{tabular}{|c|c|c|c|}
\hline Name & Corporation & Common Council & Total \\
\hline Vernon ........ & 47 & 95 & 142 \\
\hline Egmont ....... & 12 & 98 & 110 \\
\hline 'T. Towers......... & 26 & 74 & 100 \\
\hline L'Apostre ....... & 6 & 88 & 94 \\
\hline Laroche ....... & 11 & 51 & 62 \\
\hline Hucks ......... & 14 & 46 & 60 \\
\hline Hales ......... & 7 & 46 & 53 \\
\hline Oglethorpe ...... & 19 & 31 & 50 \\
\hline Shaftesbury ..... & 12 & 36 & 48 \\
\hline Eyre .......... & 6 & 40 & 46 \\
\hline Smith ......... & $\mathscr{2 0}$ & 23 & 43 \\
\hline Holland ....... & 4 & 33 & 37 \\
\hline Tyrconnel ........ & 6 & $\mathcal{2 Q}$ & 28 \\
\hline II. Archer ...... & 8 & 11 & 19 \\
\hline W. Heathcote .... & $\mathcal{2}$ & 17 & 19 \\
\hline G. Heathcote .... & 6 & 11 & 17 \\
\hline$\ldots \ldots \ldots \ldots$ & 1 & 17 & 18 \\
\hline Chandler ........ & 6 & 12 & 18 \\
\hline Tracy .......... & 3 & 14 & 17 \\
\hline Hooper . . . . . . . . & 6 & 8 & 14 \\
\hline J. Frederick . . . . . & $\mathscr{2}$ & 10 & 12 \\
\hline 'T. Frederick ..... & 3 & 7 & 10 \\
\hline Bundy ......... & 6 & 3 & 9 \\
\hline More ........... & 4 & 5 & 9 \\
\hline White ......... & $\mathscr{2}$ & 7 & 9 \\
\hline Bathurst ........ & 3 & 6 & 9 \\
\hline
\end{tabular}


Name

Lloyd .........

Ewer ..........

Cavendish

J. Phillips .......

Coram ...........

Wright $\ldots \ldots \ldots$

T. Archer ........

Wilson $\ldots . . . .$. .

Campbell .........

Page ............

Burton ..........

Anderson ....... 1

Bedford ......... 2

Carpenter ........ -

Sloper $\ldots \ldots \ldots \ldots$.

Eyles ......... -

Belitha ......... -

Cater ........... 3

Talbot ......... -

Limerick ........ -

Beauclerk ....... -

C. Tower........ -

Barrington ........

Tuffnel ..........
Common Council

9

8

5

4

- 6

3

5

3

$\mathcal{2}$

2

2

1

1

- $\quad 2$

3

4

8

7

11

1

1

3

3

3

1

1

3

4

8

7

14

1

1

3

3

3

1
Total

13

11

7

6

6

This table furnishes the clearest evidence possible that a very few men did the actual work of the Trust. So far as information is available, there were in all 1,162 reports for committee duty, and more than half of these were made by seven men. These seven seem to have had more to do with the constructive policy of the 'Trustees than all the other sixty-four members of the Trust combined; for the minutes 
of the Common Council and the journat of the Trustees make it evident that very much of their business consisted of hearing and approving the work of their committees. However, lest it give undue prominence to the committee work to select as the most prominent 'Trustees those who led in it, it will be best to combine in one table the various activities of those who ranked highest in all departments of service for the colony. The results are collated in the summary following:

THE LEADING WORKERS AMONG THE TRUSTEES IN EVERY DEPARTMENT OF SERVICE, 1\%32-1\%52

\begin{tabular}{|c|c|c|c|c|}
\hline Name & $\begin{array}{l}\text { Corporation } \\
\text { Meetings }\end{array}$ & $\begin{array}{c}\text { Council } \\
\text { Meetings }\end{array}$ & Committees & Total \\
\hline Vernon & . 394 & 176 & 142 & 712 \\
\hline Egmont ....... & 343 & 161 & 110 & 614 \\
\hline L'Apostre .... & 294 & 138 & 94 & $5 \mathcal{2} 6$ \\
\hline Smith ...... & 352 & 75 & 43 & $4 \% 0$ \\
\hline T. Towers .... & 193 & 125 & 100 & 418 \\
\hline Laroche ..... & 161 & 110 & 62 & 334 \\
\hline Hucks ....... & 187 & 82 & 60 & 329 \\
\hline Hales ... . . . . & 152 & 95 & 53 & 300 \\
\hline Oglethorpe .... & 147 & $\gamma 0$ & 50 & 267 \\
\hline Shaftesbury ... & 138 & 80 & 48 & 266 \\
\hline
\end{tabular}

Since these ten men by every test appear to have done the major part of the work in founding and supporting Georgia, it is highly important that they be studied in detail; while, on the other hand, it is not essential that those who contributed almost no service to Georgia should be discussed, however eminent and important they may have been in other fields.

It is remarkable that the name of James Vernon heads 
the list in every department of activity connected with the Trust. Not only was he first in attending the corporation, the Common Council, and committees, but he was the most consistent and regular worker among the Trustees. Several of the ten listed above were faithful and prompt when the enterprise was begun; but, as the hardships increased and as the task appeared to attract less enthusiasm and approval among the people generally, some of them became less regular in their attendance. Vernon maintained the good record with which he began his labors for Georgia, and during the last nine years of proprietary government he was absent from only four of the one hundred and fourteen meetings held by the corporation. At the meetings when he was absent, only routine business of slight importance was transacted, ${ }^{6}$ so that Vernon may be said to have participated in practically everything that was done after 1743. The attendance of other members of the corporation at these meetings varied greatly, and it was nearly always small, no other member being present at near all the meetings. One might infer from the situation that during much of the time Vernon was practically in charge of the work and that he called in others to confirm and make legal what he wished to do, though he was doubtless only leading and not entirely dominating corporation affairs. 'The part he played in the Common Council and in committees was similar to that he held in the corporation.

The general idea of his leadership during the second decade of the 'Trust is reinforced by the fact that during this period the policy for which he stood came more and more into practice. More earnestly than any other Trustee, so far as the records indicate, Vernon had advocated the plan of satisfying the colonists in Georgia and so induc-

${ }^{8}$ C. R. I: $533,536,575,576$. 
ing them actively to work in the development of the province. When they complained of the poor quality of their land, he urged repeatedly that they be given good land in proportion to the bad that they held, ${ }^{7}$ and he was willing that even the islands along the coast and in the rivers should be granted in order that the good land might be convenient for cultivation and development. When the inhabitants showed discontent on account of the strict land tenures and a lack of negroes, Vernon was inclined to yield to them in both respects." He also was the 'Trustee who suggested and urged strongly the need of a firm and orderly government in the colony which would please both the people and the home management of the province, and he outlined the form of govermment which was adopted to meet the needs of the occasion. $^{10}$ It is noticeable that in all records of debates and discussions among the 'Trustees, Vernon's opinions and arguments are given space, and his suggestions were evidently regarded as weighty by his companions. As the liberal treatment of the colonists in Georgia in the matters of land tenure, good lands, trade in rum, and the use of negroes was gradually adopted by the 'Trustees, it became evident that the policy thus advocated by him was wisest and best for the province.

Some of Vermon's best work was done in making it possible for the Salzburghers and other German Protestants to settle in Georgia. It was a help to the immigrants, and it was a valuable addition to Georgia to have them come. He was the correspondent of the Trustees in making the agreements under which they sailed; he interviewed the Society for

${ }^{7}$ C. R. V: $: 927-298$.

${ }^{8}$ Ibid., $25 \%$.

'Ibid., 3 iั8.

${ }^{10}$ Ibid., 412-413. 
Promoting Christian Knowledge and arranged with it to furnish the means for transporting the foreigners to Georgia, ${ }^{11}$ and he labored to make the colony a success after it had been established. In token of the appreciation which the foreigners felt for his labors, his name was given to the town of Vernonburgh which was largely settled by those whom he had befriended. Another work in which he was regularly engaged for the 'Trust was that of arranging with the Society for the Propagation of the Gospel in Foreign Parts for the support of missionaries appointed by the Trust to labor in the colony. He was also one of the most active supporters of Georgia in visiting the various executive departments of the British government in behalf of the province, and he was eloquent in his support of it. ${ }^{12}$

Vernon was himself a commissioner of the excise. He had earlier been an envoy to the King of Denmark, and he had been spoken of before he was twenty-five years of age as "a young gentleman who hath had a fine education, is master of abundance of learning, is very modest and sober." ${ }^{13}$ All of these traits of character and attainments he exhibited in his labors for the province of Georgia. He was a particular friend of General Oglethorpe, who said of him, "If there is a friend to be depended upon, he is one." 14 Vernon deserves to rank very near Oglethorpe in credit for the establishment and success of Georgia. The latter made more personal sacrifices for it; but Vernon worked with him in obtaining the charter, and he kept up his interest and efforts for the province after Oglethorpe and all the other founders had ceased to labor for it.

${ }^{11} \mathrm{C} . \mathrm{R}$. I: $77,137$.

${ }^{12} \mathrm{C} . \mathrm{R} . \mathrm{V}: 610$.

${ }^{13}$ Stevens I: 465.

${ }^{14}$ Wright 143-144, 165. 
Next to Vernon in activity for Georgia, was John, Lord Viscount Perceval, better known by his later title, the Earl of Egmont. He was the first president of the corporation and as such administered the oath of office to his fellow members of the Common Council. ${ }^{15}$ In almost all the lists of the 'Trustees occurring either in the charter or in the records of the Trust, his name stands at the top, for he was recognized as a leader among them. Had it not been for his resignation from the Common Council in 1742 and his death in 1748, he might have equalled or even surpassed Vernon in his attention to Georgia affairs, for they were almost equally prompt in service until 17.2, Egmont being perhaps a somewhat more dominant figure than Vernon. In spite of his gout and other physical handicaps, he took the lead in the affairs of Georgia, and he seemed to oceupy in England a position somewhat similar to that of Oglethorpe in America, being the person to whom others generally looked for suggestions and directions. To him were sent more letters and reports concerning the province than to any other 'Trustee, and he was formost in pressing the claims of the colony for help and support, knowing better than any other its circumstances and needs. ${ }^{\mathbf{1 6}}$

Like Vernon, the Earl of Egmont was inclined to be liberal toward the colonists; but he was more cautious in his policy. He opposed the giving of good lands for bad too hastily, urging that a more carcful study of the facts should be made. His attitude was that the colonists ought to make a good showing with what they had before they should be allowed their full requests. ${ }^{17} \mathrm{He}$ was also opposed to the use of negroes, either free or slave, in Georgia ; but his oppo-

${ }^{15} \mathrm{C} . \mathrm{R}$. I: 66.

${ }^{16} \mathrm{C}$. R. $V^{\gamma}: 636,639,641,271-273$, for example.

${ }^{17}$ Ibid., $227-228$. 
sition was not harsh and overbearing like that of some of the other Trustees. ${ }^{18}$ He strongly favored alterations in the land tenures so as to conform to the desires of the people of Georgia, giving as his reason for his position on the matter a desire to conciliate the settlers in every possible manner consistent with the purposes of the colony. ${ }^{19}$

Though raised to the rank of an earl under the Walpole administration, he occupied an independent position in politics. He discloses a good deal of animus against Walpole himself at various times, accusing him of deliberately falsifying in order to get the support of the Trustees. ${ }^{20}$ Egmont himself felt that it was best for him and for the other Trustees to make no alliance with either party, putting the interests of Georgia ahead of the success of any faction. ${ }^{21}$

Were his devotion to the colony not so manifest on many occasions, it might be questioned in view of the circumstances of his resignation. When Parliament refused a supply of money in the spring of 1742 , he spoke of throwing up the whole Trust because both the ministerial party and the minority in Parliament seemed to appreciate so little the labors of the Trustees. He did not meet with encouragement in the idea and he dropped it for the time. ${ }^{22}$ Later in the year, after Thomas Stephens had been reprimanded for attempting to asperse the charaeters of the 'Trustees, and after another effort on the part of the supporters of Georgia had failed, the Earl of Egmont in hasty indignation resigned his place as a member of the Common Council on July 7 , 1742. If any means of resigning from the corporation had been provided, he would likely have given it up also, for he ${ }^{18} \mathrm{C} . \mathrm{R} . \mathrm{V}: 378$.

${ }^{19}$ Ibid., 379 .

${ }^{20} \mathrm{Ibid}$., 34, 88, as examples.

${ }^{21}$ Ibid., 112.

${ }^{22}$ Ibid., 612. 
was thoroughly roused. His action was ill considered. His letter enclosing his resignation did not touch on what was the real seat of trouble, which was the hope of getting others also to resign and so forcing the government either to support Georgia or to give it up. ${ }^{23} \mathrm{He}$ failed in his purpose of getting others to follow his example; and it was well for the colony that he did so fail. If the charter had been surrendered at that time, it is most certain that Georgia would either have been surrendered to Spain or would have been joined to South Carolina, and in either case its independent character would have been lost. The reasons assigned in his letter of failing health and his physician's directions to rest would have been ample excuses for his resignation were it not that he himself gave a different interpretation of his own action.

The Earl of Egmont was disposed to judge harshly the motives and actions of his fellow Trustees, and he would have been very severe toward another acting as he did in that matter.

Egmont had had a somewhat distinguished career before he became comnected with Gcorgia. He had been Privy Councillor for Ireland. In 1715 he had been made Baron Perceval; and in 1722 he had been created Viscount. His advancement to the carldom was in 1733, his interest in Georgia possibly having some influence in his promotion. He was a Fellow of the Royal Society. Egmont was the author of several tracts or small books, most of which were concerned with the advantages of Georgia and the need of its support. ${ }^{24}$

Henry L'Apostre, the Trustee ranking third in faithful attendance on the duties of his office, seems to have been a ${ }^{23}$ C. R. V: 643-644.

${ }^{24}$ Ibid., 273-275; Stevens I: 463-464. 
man of much less force of character than either Vernon or Egmont. He was not a member of Parliament, and almost nothing is known of his private life. While he was regularly in his place at the meetings of corporation, Common Council, or committees, arguments or suggestions from him rarely appear in the proceedings, indicating that his influence was perhaps not very great among his fellow Trustees. His committee service was to a large extent connected with financial or banking affairs, ${ }^{25}$ and it might be inferred that he was experienced in such matters, but there is no corroborative evidence to support the inference. He did not share Vernon's view of conciliating the people of Georgia, but opposed humoring them as to either land tenures or negroes. ${ }^{26}$

Reverend Samuel Smith was a graduate of Magdalen College, Oxford, and he was the rector of All Hallows on the Wall. He was early impressed with possibilities for good in the Georgia enterprise, and he preached a sermon for the special purpose of recommending the charity. In consequence of this and other services, an application was made by the Trustees to the Right Honorable the Lord High Chancellor for some preferment in or near London to be given to the Reverend Mr. Smith "for the great Service he has been of to the 'Trust." 27 Like Mr. L'Apostre, he seems to have been more faithful in attending meetings than prominent in his participation in them. He aided Vernon in securing the interest of the Society for Promoting Christian Knowledge in the removing of the Salzburghers from Germany to Georgia; and he was active in all religious enterprises of the 'Trust. ${ }^{28}$

\footnotetext{
${ }^{25}$ C. R. II: 248; C. R. V: 707, as examples.

${ }^{28} \mathrm{C} . \mathrm{R} . \mathrm{V}: 378$.

${ }^{27} \mathrm{C} . \mathrm{R}$. II : 60 .

${ }^{28}$ C. R. I: 114, 209, as examples.
} 
Thomas 'Tower was one of Oglethorpe's closest friends among the 'Trustees, ${ }^{29}$ and they were in thorough accord as to many matters of importance in colonial affairs. Neither of them was willing to yield to the clamors of the Georgians for better land tenures, the exchange of bad lands for good, the traffic in rum, or the introduction of negroes. Tower had been on the committee which framed the regulations for the colonists, ${ }^{30}$ and he had satisfied himself that they were suitable and necessary; and he felt, as did Oglethorpe, that those complaining ought to be entirely disregarded unless they were improving their lots the best they could before making their complaints. Accordingly he opposed more than any other 'Trustee the various concessions that were made to the people. ${ }^{31}$

Tower was a good speaker in the House of Commons; 32 and he was a lawyer of ability. His legal services were the most valuable that he rendered to the Trustees. He was on nearly all committees that were appointed to prepare laws, draw up instructions for magistrates in Georgia, or to put papers into the proper legal form. ${ }^{33}$ In this respect he was perhaps the most active and able Trustee. He also served the Trust at times by interviewing Sir Robert Walpole to get his approval of measures desired by the friends of Georgia; in this capacity he was effective, but he was unwilling to do much service of the sort. In fact his close allegiance to the Walpole party greatly hampered him in his usefulness to the Georgia 'Trustees. In order to please this leader, Tower was willing to surrender Georgia to the

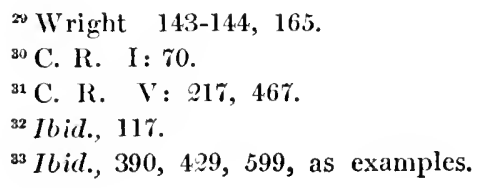


Spanish without a serious fight to retain it. ${ }^{34}$ To further please him, he undertook with another Trustee to defend the English title to Georgia, though the Trustees as a whole very strongly disapproved of the measure, thinking that it was a matter to be settled by the law officers of the Crown and fearing that an unsuccessful defence would be used as an excuse for giving up the province. ${ }^{35}$ Friendship for the Walpole party also led 'Tower to oppose any effort to make the corporation independent of politics; he did not wish the Trustees to petition Parliament for the protection of Georgia, and he frequently insisted that the demands for money be cut low enough to please the Lord Chancellor. It is not certain but it is probable that his refusal to speak for the colony in the House of Commons and his indifference on other occasions may be explained also on the basis of his political alignment. ${ }^{36}$

Hucks and Laroche were two other strong supporters of Walpole among the Trustees; and their general position on all matters of importance was that of Thomas Tower. Hucks was at first one of the most interested and faithful of the little group who were launching the enterprise of the new colony, but his political connections were a source of weakness to him as a Trustee, and his father thought that the brewing business in which they were engaged suffered because of his son's occupation with Georgia affairs. ${ }^{37}$ Accordingly he withdrew from the Common Council, and after a little time he seemed to lose all interest in the Trust, failing to uphold it in its efforts to get support from the House of Commons. ${ }^{38}$

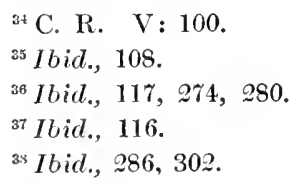


Though Laroche was a steady adherent of Walpole and on that account was not perhaps always as useful to the Trust as he could have been, he was ever ready to defend in the House of Commons both the province of Georgia and the management of it by the Trustees. ${ }^{39}$ His connection with Walpole was not an unmixed disadvantage, for he was a useful committeeman in securing the aid of Sir Robert. in many affairs in which Georgia was concerned. In regard to the policy to be pursued in the province, he inclined to a conciliatory attitude toward the inhabitants, as did Vernon and Egmont. ${ }^{* 0}$

One of the most eminent of the active Trustees was Reverend Stephen Hales, D. D., who was a charter member of the corporation and who was the only minister who continued faithful all through the years of proprietary control. He was a graduate of Bennet College, Cambridge, and he also was given the degree of doctor of divinity by the rival University of Oxford. In 1717 he was chosen a Fellow of the Royal Society, and in 1739 he won its gold medal for a scientific essay. At a later time he was elected a meniber of the Academy of Sciences in Paris. He was one of the foremost naturalists of his day and he was "pious, modest, indefatigable, and born for the discovery of truth." ${ }^{+1}$ Being closely associated with the royal family, he was offered preferment as preacher, but he retained his position because he thought he could render more service in it than if he accepted advancement.

In his duties as Trustee, he seems to have been interested chiefly in the charitable side of the enterprise. During the early years of the undertaking he was instrumental in secur-

${ }^{30}$ C. R. V.: 433, 444, 446, as examples.

${ }^{40}$ Ibid., 371 .

${ }^{4}$ Stevens I: $467-468$. 
ing many gifts for carrying on the work. He does not seem to have taken much part in the discussions or debates as to policies to be pursued, and his opinions on them are not eited in the records. He was interested with Vernon in the religious welfare of the people in Georgia, consulting the Society for the Propagation of the Gospel and aiding in the settlement of foreign Protestants in the province.

Concerning the work of James Oglethorpe as a Trustee, the following chapter gives ample information. Had he been as interested after 1743 as he was when the work was first begum, he would have ranked with Vernon and Egmont in his attendance, and his right to the first place among the Trustees could hardly have been questioned. As it is, the position of honor assigned him is based on his activities during the first decade of the Trust.

Anthony Ashley Cooper, fourth Earl of Shaftesbury, was one of the mainstays of the Trustees after the Earl of Egmont resigned from the Common Council. Shaftesbury seems to have acted always in perfect harmony with Vernon, and he was the latter's most frequent associate during the closing years of proprictary management. His service in the Common Council was not continuous. Elected in 1733, he served until the question of the convention with Spain was settled in Parliament in 1739. Being a member of the Minority at that time, he was greatly exasperated that so many of the members of the Common Council supported Walpole in the vote on the convention and he resigned in disgust his place on the Council. The resolution to resign was hastily reached, being brought about by the influence of Lord Limerick and other Minority leaders; and, while it was much resented by his fellow members who felt that they had a right to vote in Parliament as they pleased, the Trustees were disposed to overlook his rashness on account 
of his youth and the influence of older men. ${ }^{42}$

The next year through the influence of the Earl of Egmont, Shaftesbury was persuaded to return to the Common Council. He was warmly welcomed and his rejoining the body gave credit to the sinking fortunes of the 'Trustees; for, as one of them described him, he was a "nobleman of all amiable qualities and not one vice." 43 His high rank and known character made him useful in all committee service affecting the various departments of the government, and he was the leader in the negotiations which resulted in the British government's assuming the support and control of the province in $1752 .{ }^{44}$

Among the seventy-one Trustecs who were appointed or elected during the twenty years of the Trust, there were many men who were influential, interested and active during certain portions of the time, but who withdrew from the Common Council so soon, or were elected to office so late, that they did not exercise sufficient influence on the whole course of executive management to be ranked witl those whom we have been considering. A few of these ought to be mentioned. Among them Henry Archer was one of the most energetic and useful. Holding oflice in the C'ommon Council from 1734 to 1744 , he was concerned in all the legal and political problems of that stormy period of the Trust. He was allied with Thomas rower in politics but he was more independent than most of the Walpole group, frequently breaking from his chief in minor matters and nearly always defending the Trustees in the House of Commons." He served on nearly all the committees appointed

\footnotetext{
42 Stevens I: 13?-133.

${ }^{43}$ Ibid., 318, 325.

${ }^{44}$ C. R. I : 569 et seq.

${ }^{45} \mathrm{C} .1$ R. $V: 120,286$.
} 
to interview the Chancellor of the Exchequer, the Speaker, or other officials of both Walpole and Wilmington-Carteret ministries. ${ }^{46}$ During his term of office he probably also served oftener than any one else on committees to draw up laws or to determine the legal responsibility of the Trustees, being generally associated with Tower in this work.

George Heathcote, on account of failing health, was not so regular an attendant at the meetings as the others already mentioned, but he served apparently without pay as cashier or treasurer of the Trust until March 22, 1740. The duties of the office were not taxing but they required time and attention. It was customary to deposit about five hundred pounds at a time with the cashier with which to pay the minor expenses of the Trust. The larger amounts were paid by direct drafts on the Bank of England, signed by any five of the Common Council. Heathcote was dissatisfied with the policy of the Trustees in support of the Church of England in Georgia, ${ }^{47}$ but he was a good friend of the colony and of the Trustees after he ceased to be actively associated with them, defending them ably in Parliament on several occasions. ${ }^{48}$ He was an alderman of London, and in 1740 , the year he resigned from the position of cashier of the Trustees, he was elected Lord Mayor of London, but declined to serve. ${ }^{49}$

Sir William Heathcote was one of the few nembers of the Trust who, having resigned from the Common Council, continued to attend the meetings of the corporation. He was a man of recognized worth and good sense and he also had a large fortune; it was with regret that his fellow members

${ }^{46}$ C. R. V: 600, 607, as examples.

${ }^{47}$ Ibid., 116.

${ }^{48}$ Ibid., $994,444$.

${ }^{40}$ Stevens I: 464. 
of the Council gave him up. He resigned in 1739 and it was thought by Egmont that he was persuaded to this course by George Heathcote, Lord Limerick and other Minority members of Parliament who had already persuaded the Earl of Shaftesbury to withdraw. ${ }^{50}$ Heathcote in his letter of resignation professed great love for the colony, regretting that private affairs prevented his further service in the Council, and he did afterwards as an ordinary Trustee render service to the cause, being the only one to aid the members of the Common Council in transferring the responsibility of the Trustees to the Crown when the charter was surrendered. ${ }^{51}$

Very few of the Trustees who were not also members of the Common Council were regular in attending the meetings of the corporation. To this general rule, Adam Anderson was in a measure an exception. He was a clerk in the South Sca House, and he was afterwards an author of some note; but he seems to have been of comparatively little influence in the Georgia board, his faithful attendance being his principal merit.'

Three members elected to the 'Trust during its declining years deserve special mention. These were Samuel Lloyd, Edward Hooper, and Anthony Ewer, all of whom were of great assistance to Vernon and Shaftesbury in maintaining the work of the board at a time when some of its older friends were falling away.

On the whole, the Trustees were an able set of men. They represented well the leading political and religious beliefs of England, and they included persons of varied experience and occupations in life. Since they were thus varied in their personnel, it is not strange that there were among them ${ }^{50}$ C. R. V: 230.

${ }^{51}$ C. R. II : 506 . 
causes of misunderstanding and disputes. The most serious of the disagreements among the members of the Trust grew out of politics centering about the support of Walpole or opposition to him. We have seen that feeling over this matter caused the withdrawal of some members from the Common Council. Perhaps next in importanee to the political differences were those over religious matters. The large majority of the 'Trustees were members of the Church of England, and they were anxious that it prevail in Georgia; but there were also many Presbyterians and other nonconformists on the board, ${ }^{52}$ and these were disgusted with the resolution of the majority of the corporation to support a church establishment. Whether this difference caused the withdrawal of members or not, it produced a coolness among some of them. ${ }^{53}$

Less can be said of the self-sacrifice of the Georgia Trustees than of their ability. Of the seventy-one who were chosen, thirty-six seem to have contributed no money to the enterprise, and the whole sum contributed, according to their own accounts, was only about nine hundred pounds from their own resources. ${ }^{54}$ The test of contributing money is not final as to the interest a man may have in an enterprise, but when the undertaking is charitable in its aims and dependent on charity for its support, the amount given by the Trustecs may be some measure of the regard in which the colony was held by its managers. The attendance percentage of the whole body of Trustees on the meetings of the corporation was only 17 per cent. of what it might have been, as shown on pages 31-34 herein. It was the case 52 Wright 165.

${ }^{5}$ C. R. V: 116 .

${ }^{5-}$ Bouverie, one of the Trustees, gave $£ 1000$; but it was from a fund in his possession left for charity; it did not come out of his own resources. 
with many of the Trustees that as soon as their vanity was satisfied by their election to so honorable a body as the Georgia board they lost much of their interest in the work; and when affairs in the colony went badly and when debts began to accumulate, such members ceased entirely to act with their colleagues. It was only a small handful that stuck to their duty through fair weather and foul until the end. And yet who can blame the Trustees for quitting their task? No financial rewards awaited them, and little honor was attached to the office after the early years. The duties were arduous and the performance of them was greeted with criticism from the government at home and complaints from the colonists in Georgia.

The criticisms just made apply only to the whole body of seventy-one members. The self-sacrifice of the working members of the Trust-Oglethorpe, Vernon, Egmont, L'Apostre, Smith, Hales, Shaftesbury, and a few others like them-cannot be too highly praised. To these few may be applied the words used by a historian of Georgia in summing up the work of the whole body: "At every stage of progress and in every act, whether trivial or important, these trustees, capable and worthy, evinced a clear conception of duty, a patience of labor, a singleness of purpose, an unselfish dedication of time and energy, an integrity, and a rigid adherence to all that was pure, elevated and humanizing, which become quite conspicuous when their proceedings are minutely and intelligently scanned." 55

s Jones-Hist. of Ga. I: 443. 


\section{CHAP'TER III}

THE RELATION OF OGLETHORPE TO GEORGIA

NE of the interesting problems of the colonial history of Georgia is the relation and importance of James Oglethorpe to the settling and developing of the province. Was he the father of the enterprise? Was he responsible for the plans and rules under which it was attempted? What motives prompted him to accompany the colonists to America? Was his presence of real benefit to the colony? What were his legal powers in Georgia? What led to the later friction between him and the Trustees and to his withdrawal from participation in Georgia affairs? The answer to at least a portion of the questions may be found by examining the principal facts of his life and by following in order the various entries in the records of the 'Trustees regarding his activities under their directions.

No detailed account of Oglethorpe's life is necessary, and indeed the facts are not sufficiently established to warrant a full summary of his life before he went to Georgia. He was born on June 1, 1689. He matriculated at Corpus Christi College, Oxford, though the date of his entrance is in doubt, but he soon left his college work for service in the arny. In 1710 he was an ensign in the British army and served till the war ended in 1713. It was in this war of the Spanish Succession that he got his first contact with the Spanish, a contact which was to be hostile when renewed in America. Soon after the Treaty of Utrecht, he entered the 
service of Prince Eugene of Savoy, with whom he continued until 1718, when he returned to England. There is no definite information available as to the amount or the quality of the service rendered by Oglethorpe during the time he was connected with the army. Many conjectures have been made as to his attainments in military science and experience; but they are inferences from his later career rather than actual facts. ${ }^{1}$

On the death of his brother 'Theophilus, he inherited a considerable estate at Westbrook, and he settled down to what gave promise of being the ordinary life of an English gentleman. His manor was situated near Godalming in Surrey county and was sufficient to enable him to live in independence and comfort. Like so many of the country gentlemen of the period, he was a Tory in politics, though his later career indicates that he was not an extremist in his political faith. In 1729 he was chosen as one of the representatives in Parliament of the town of Hastemere, which was located in Surrey county not far from the Oglethorpe estate, and he continued in this relation until he was defeated in $1754 .^{2}$ His father and both his older brothers had formerly represented the same borough, and this was probably a help to him in gaining the position, but the fact that he held it so long indicates that he must have been satisfactory to his constituents.

Oglethorpe seems to have taken no active part in parliamentary affairs during the first six or seven years after his election. It was not until 1799 that he attracted any considerable attention. In that year he was made chairman of a committee of the House of Commons whose business it was to visit and report on the condition of the Fleet, Marshalsea,

1 Wright 5, 7.

${ }^{2}$ Ibid., 12, 373. 
and King's Bench prisons. The committee was composed of fourteen members, and it seems to have been appointed on the motion of Oglethorpe, who had learned something of prison conditions through a visit to one of his friends who was incarcerated for debt. It is not entirely clear that he inaugurated the movement, but as chairman of the committee he was active in the work and he presented to Parliament the results of the investigations. ${ }^{3}$ The first of these reports was submitted to the House on March 20, 1729, and the last was on May 11, 1730. With details of the reports we are not now concerned, but it is worth noting that the work seems to have been done with expedition and thoroughness. Bills were introduced by $\mathrm{Oglethorpe}$ to ameliorate the wretched conditions which the committee had found and to punish the worst offenders among the prison wardens. ${ }^{4}$

In other respects Oglethorpe began to show himself interested in the unfortunate or the oppressed. On January 13, 1732, he made a speech in the House of Commons in which he showed sympathy for the persecuted Protestants of Europe and expressed the wish that something might be done for their relief. ${ }^{5}$ He was also a member of the Society for the Propagation of the Gospel in Foreign Parts, and in addition he was on a council of fifty who looked after the support and education of exposed and deserted children. In "The Sailor's Advocate," he defended seamen against the worst evils of impressment. He ably advocated the petition of the Moravians for assistance, and he sustained a motion to relieve the poor of certain of their most burdensome taxes. ${ }^{6}$

${ }^{3}$ Cobbett VIII: 706 et seq.

${ }^{4}$ Ibid., 706-753, 803-826.

${ }^{5}$ Ibid., 875-876.

${ }^{6}$ Stevens I: 82-83. 
As to whether or not Oglethorpe first thought of or suggested the scheme of making the settlement of Georgia, the evidence is not sufficient for a definite decision. Original documentary evidence that he fathered the idea is lacking. "The Political State of Great Britain," a periodical of the day, in referring to the colony in August, 1732, soon after the charter was made public, mentions Viscount Perceval as "one of the principal Promoters of that Great and Generous Design." It makes no mention of Oglethorpe or other Trustees as being especially prominent in the work. "The Castle-Builders," a life of William Stephens, states that Thomas Coram and William Sloper, two of the original Trustees, "at first projected the colony." There is no apparent reason for falsifying in the matter; but the book is generally unreliable, and no great importance should be perhaps attached to its testimony. It is only noteworthy that Oglethorpe in neither of these publications is credited with originating the project. ${ }^{S}$ In none of the lists of those interested in the matter is his name mentioned first. In the charter three men are named ahead of him on the rolls of both the general board and the Common Council. Neither was he made the first president of the corporation or the first chairman of the Common Council. In some of the references to the petitioners for the charter as recorded in the "Acts of the Privy Council," his name does not appear at all, though it is quite likely that he was included under the general term "and others." After the petition for the charter had been referred to the Board of Trade for investigation, Oglethorpe wrote to the Board a number of suggestions. Among other things he proposed for the new corporation the name, "Corporation for Establishing Char-

${ }^{7}$ Polit. State XIIV: 149-151.

${ }^{8}$ Castle-Builders 106. 
itable Colonies," which was for a while considered but was finally discarded. Just what were his other suggestions and whether they were adopted or not cannot be ascertained. ${ }^{9}$ After the Board of 'Trade had made its report, Oglethorpe in company with others appeared before a committee of the Privy Council to ask for certain changes in the report in order that the trustees might have more power than was proposed in the matter of selecting the civil and military offices of Georgia. ${ }^{10}$

In no case above cited does Oglethorpe seem to have exercised more influence than any other of the active petitioners for the charter. That is not proof positive at all that he was not more influential, nor would it prove that he was not the originator of the project. There are a number of indications that such honor ought to be given him. By common consent the historians of Georgia and the biographers of Oglethorpe agree that he was the first to propose the settlement and that it was tlrough his efforts that the other men who later became Trustees became interested in the work. The literature of the time paid tribute to him as pre-eminently benevolent of soul, but the compliments paid him in nearly every case came after he had gone to Georgia, and they were seemingly called forth on that account rather than because he was the author of the scheme. The fact that he had shown already indications of interest in imprisoned debtors and in foreign Protestants, and the additional fact that he was prominently connected with several other charitable enterprises, are perhaps the best reasons for thinking that he would and did originate the plan for settling the new province. Whatever may be the facts about its

- Abstract of Board of Trade (Cited B. T.) Papers, S. C. Hist. Collec. II : 127 .

${ }^{10}$ Acts of Privy Council, 1720-1745: 301-303. 
origin, Oglethorpe was indisputably earnest in helping to carry forward the project.

It has been incidentally mentioned that he was a member both of the general corporation and of the Common Council which was to do so much of the actual work of government. He was faithful in attending the meetings of these bodies. Before he left England, there were nineteen meetings of the general Board of Trustees, and Ogletlorpe was present seventeen times. Only one other nember of the Board equalled him in faithfulness. 'There were, in addition, seven meetings of the Common Council, and he was present at six of these, being surpassed by two members and equalled by four others in regard to the number of times in attendance. He was also active in the comnittee work of the early organization. For the Common Council he served in this capacity six times before leaving England, being equalled in this particular by only two others. For the general Board he also served on six conmittees, having only one man to surpass him in activity. In this connection it is worthy of note that Oglethorpe served on the most important committees. He was the chairman of the one to draw up laws and regulations for the colony, ${ }^{11}$ and we shall have occasion to discuss later whether or not the work of this committce was wisely done. He was appointed a committee of one to see that the project was given the proper publicity through the newspapers and also to prepare commissions and boxes for those who should be willing to solicit funds for the enterprise. ${ }^{12}$ He seemed for the time being to have charge of the receipts and disbursements, for which he rendered a regular account. ${ }^{13}$ Whether on account of his

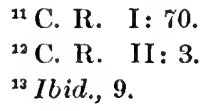


financial relation to the undertaking or because of his greater interest in it, he reported more names to the Board of those who were willing to solicit money for the work than any other 'Trustee. In addition to the activities already noted, he is thought to have written in behalf of the new colony the pamphlet entitled, "A New and Accurate Account of the Provinces of South Carolina and Georgia." 14

When preparations for the first embarkation of colonists to Georgia were being made, Oglethorpe decided to accompany the new settlers in person. His object as stated in the papers of the time was merely to see that the colonists were safely located in their new homes. ${ }^{15}$ 'This determination seems to have been entirely voluntary on his part; but, while the Trustees had not urged him to the course, they were glad to avail themselves of his generous offer. The people who were going to Georgia were almost all of good eharacter, but they had not hitherto been successful as a rule in managing their private affairs; and so it could not be reasonably expected that they would be capable of directing a whole settlement. Some guiding hand was needful. 'The normal thing to do was to appoint a governor who would be strong and experieneed enough to put into operation the various plans of the Trustees; but the latter were unwilling to appoint such a governor lest they should lose some of their authority, since the charter provided that a governor must be obedient to the Crown as well as to the Trustees. They seemed to feel that if Oglethorpe went over to get things well started the colony could prosper without much government; and they certainly acted on this theory whether they consciously. held it or not. Oglethorpe probably sympathized with his fellow Trustees in desiring

1* Ga. Hist. Collec. I: 49.

${ }^{15}$ Gent. Mag. 1732, Vol. II : 1029. 
to keep independent of government control, for this was ever his later policy whenever it was possible. Another reason why he may have been induced to undertake the journey was his love of adventure. He had served as a gentleman volunteer on the Continent before entering the English army, and he had later joined the Austrians against the 'Turks, as we have noticed; and the establishing of a buffer colony against his old opponents, the Spanish, would doubtless appeal to him on the military and adventurous side. There is no good reason for doubting, however, that he was greatly, and perhaps mainly, moved by compassion for the poor debtors and other unfortunates who were preparing to go to a new country, and who would need all the help and advice obtainable in order to succed. His action was regarded in this light at the time; and he was highly eulogized for leaving his home and the comforts of society and the pursuits of anbition in order to do a work from which he could hope to receive no private advantage. ${ }^{16}$

It has frequently been stated on high authority that Oglethorpe was the first governor of Georgial. It was impossible that he should hold that office. He was forbidden by the terms of the charter, as were all the rrustees, to hold "any office, place, or employment of profit under the corporation." Further, as a Trustee, he was forbidden to receive or take, directly or indirectly, any salary, fee, perquisite, benefit or profit whatever by reason of service rendered the corporation in any manner or capacity. ${ }^{17}$ It might be urged that these requirenents forbade the holding of only those offices which were "of profit," and that he night well have oceupied the office of governor because he went at his own expense. ${ }^{18}$

${ }^{16}$ Polit. State XLV : 181.

${ }^{17} \mathrm{C} . \mathrm{R}$. I: 16 .

${ }^{18}$ C. R. III : 378. 
It is difficult to dissociate the idea of a salary from that of a governor in any ordinary sense; but whatever the possibilities in the case might have been, the fact remains that Oglethorpe was not granted authority or powers that would entitle him to be called the governor of a province or even of a single sectlement. It seems not to have been anticipated that he would remain longer in the colony than might be necessary to actually establish the colonists in their homes in peace; and so the powers given him were in a measure temporary and by no means extensive. For example, he was given power to set out and divide 5,000 acres of land that had been deeded in trust to three of the settlers, and he was to give directions to these holders of the land in trust how to proceed with their business of assigning it to the other settlers. He was authorized to grant licenses to those desiring to leave the province of Georgia so that they might not forfeit their grants. ${ }^{19}$ He was entrusted with the special authority to administer the oaths of allegiance, supremacy, and abjuration to the various officers appointed in the new colony; but it was not a general power to administer oaths, since the individuals were specified by name. ${ }^{20}$ He was also grantcd the power as attorney for the Trustees to name officers for the militia of Georgia. ${ }^{21}$ The last appointment gives the keynote of the relation that Oglethorpe bore to the Trustces. He was not a governor under them, but their attorney to act in their stead. Nor was he an attorney with general power to act, but he was limited to the special matters in which authority was assigned him.

It is beyond question that it would have been a wiser policy for the Trustces to give to him or to some other man

${ }^{19}$ C. R. II : 9-10.

${ }^{2 n}$ Ibid., 11.

${ }^{21}$ B. T., Ga., XII: 25. 
larger powers specifically or, better still, more general powers to act. In the nature of things, there would arise many circumstances demanding prompt action which could not be foreseen and specifically provided for by the Trustees. Many such occasions did arise; and Oglethorpe usually acted as he thought best, though not authorized to do so. For instance, none of the records indicate that he was authorized to draw on the Trustees for money; but he did so, and no protest was made in the beginning at least, ${ }^{22}$ though we shall see that it led later to unfortunate misunderstanding.

Having noticed the part played by Oglethorpe in getting the project launched in England, and understanding the powers granted him and his relations to his fellow Trustees, we must next estimate some of the services he rendered in actually planting the settlement in Georgia. This side of his career has been so fully developed in his biographies and in the histories of Georgia that we shall merely refer to the various incidents without giving details. It has already been noted that in going to Georgia Oglethorpe could hope for no financial remuneration on account of provisions in the charter; but it would be a strict interpretation of the provisions that would necessitate his paying his own expenses for the journey, and so his expenditures in this particular must be considered as a gift to the cause. Not only did he furnish his own cabin and provide for his servants, but he also relieved the burdens of the voyage by contributing to the comforts of his fellow passengers. ${ }^{23}$

When the colonists reached Port Royal, South Carolina, Oglethorpe proceeded with Colonel William Bull to the Savannah River for the purpose of selecting a site for the

${ }^{22}$ C. R. II: 27 .

${ }^{23}$ Wright 58 . 
proposed settlement. This was a matter of prime importance, affecting every person who might locate in the town to be established. This work was well done; the spot chosen was perhaps the best possible one for the town of Savannah. It is very likely that credit is due both to Oglethorpe and Bull for the decision made; but, as the former had final authority in the matter, he is entitled perhaps to the greater commendation. ${ }^{24}$

In his personal contact with the early settlers, and in his handling the details of the settlement, Oglethorpe seems to have been very successful. He worked hard himself and spared no pains to get the town started properly. He was much beloved of the people, who gave him the title of "Father." He visited the sick and took care of them. If there were differences, he decided the matters at issue himself; and for the time at least there seemed to be little dissatisfaction with his judgments. He was strict in discipline, allowing neither drunkenness nor swearing. He laid out a great deal of work and was successful in getting much of it done, permitting no idlers around him. ${ }^{25}$

Oglethorpe showed as much tact in dealing with the Indians as he exhibited good judgment in the choice of a site and industry in getting the settlement started. There had been a former treaty between the Indians and South Carolina that no white settlements were to be made south of the Saramnah without the consent of the natives; and they were at first inclined to object to the coming of the Georgians. On his first visit for the purpose of selecting the location for the town, Oglethorpe had held an interview with 'Tomochichi, the chicf of the small Indian tribe living near the river; and with the aid of a half-breed interpreter, Mary

${ }^{24}$ C. R. III : 380.

${ }^{25}$ Polit. State XLV: $543-544$. 
Musgrove, had persuaded him that it would be advantageous to the Indians that the white men should come. This interview was the beginning of a firm friendship which lasted between the English and the Indians during almost all of the proprietary history of the colony. Through the influence of Tomochichi, the other Indian tribes within the limits of Georgia were gathered for a conferenee, at which Oglethorpe treated them with so much candor and tact that they readily eeded to the English the lands desired and entered into a treaty of friendship and commeree. ${ }^{26}$ For the weak and strugghing settlement, the friendship and assistance of the matives were worth more than fortifications or troops; and nobody could have been more successful than was Oglethorpe in bringing about the cordial relations.

These were the most valuable achievements of the leader of the Georgians, but there were a number of things besides whicl oecupied his attention. He provided for the defence of the town of Savannah by planting a battery and establishing a few outposts like Fort Argyle and Thunderbolt. He laid out the town into convenient wards and tithings. He explored the lower coasts of the province and made notes of the best methods of fortifying it. Just before leaving Georgia for England, he accompanied the newly arrived Salzburghers for the purpose of selecting a site for their town; in this he was not so fortunate as in his choice of a location of Savannah, but for the time being the Germans were well pleased with it. When he finally set sail on March 23, 1734, the people could hardly restrain their tears, because he had eared for them much like a father both by night and by day for more than a year. ${ }^{27}$

On the whole, Oglethorpe was most useful to the colony

${ }^{26}$ C. R. III: 381.

27 Yon Reck, Extract from "Journal" 18, cited by Wright 80. 
and very successful in managing its affairs during his first stay in Georgia. He showed industry, foresight, good judgment, tact, and sympathy for the people. To this point certainly, the province would have been no better off if it had had a regular governor of the best caliber. 'The principal error, it secms to us, that had been made hitherto was in failing to establish the magistrates in office at the very beginning. During the first five months, he kept to himself all authority of every sort. ${ }^{2 s}$ There is little doubt that he was a better judge and a wiser magistrate than any who had been appointed by the 'Trustees; but he could not excrcise all the authority satisfactorily, and he would not be in America continuously, so that it would have been better to allow the appointees of the Trustces to enter at once upon their duties. One of the greatest handicaps the province had was lack of respect for its officials; and this was to a great extent due to the general impression that they were dependent for power on Oglethorpe and that he could veto or alter their actions. It could not be foreseen perhaps that bad results would follow the postponement of inducting the officials into office, and so it was due to an error rather than to a fault that it was not done immediately.

Before he left Georgia, Oglethorpe had been remonstrated with by the Trustees for drawing bills on them without sending letters of advice to explain the necessity of the draft. Several such drafts were sent; and the matter became so troublesome that on February 6, 1734, a resolution was passed to the effect that no bill drawn by any person whatsoever be accepted or paid by the Trustees unless it be accompanied by a proper letter of advice. This was not enforced with entire strictness against Oglethorpe, however, for they later paid some of his drafts which had not been ${ }^{28}$ Wright 73. 
properly certified. ${ }^{29}$ During these early days, he seened to manage his accounts rather well. Out of a total of about

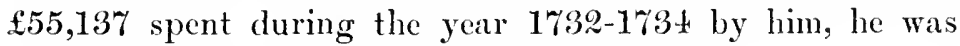
able to produce vouchers for all but $£ 1,874 .{ }^{30}$

The 'Trustees were duly appreciative of the work that Oglethorpe did for the establishing of the settlement. On June 13, 1733, Secretary Martyn wrote to know how long he could remain in the colony and asking who could best superintend the work when he left. Under date of September 1, 1733, he wrote again, expressing appreciation of what had already been done and telling him that the 'Trustees wished to send over as many settler's as possible before he left. Again on November 22, 1733, Martyn regretted that the people were misbehaving and feared that the troubles might revive when Oglethorpe left the province. ${ }^{31}$ In addition to the appreciation expressed, all these communications indicate that Oglethorpe's stay in Georgia was expected to be only temporary and that his great work was that of smoothing over the difficulties encountered in the beginning. When he reaclied Fngland in Jume, 173t, he was welcomed by an unusually full meeting of the 'Trustees, and he was heartily thanked by them in a unanimous resolution for the "many and great services he has done the colony of Georgia." 32

The general public received him with demonstrations of high regard and honor for the work he was doing. Whatever may have been the case in the beginning, he was at that time regarded as the decided leader in the founding of Georgia. Poems in his honor were published in "The Gen-

${ }^{29}$ C. R. II : 53, 56, 58.

${ }^{30}$ Ibid., 117.

${ }^{81}$ B. T., Ga., VIII : Letter book arranged by dates.

${ }^{32}$ C. R. I: 175 . 
tleman's Magazine," and medals were struck to commemorate his work, while the nobility and gentry poured congratulations upon him. ${ }^{33}$ His one year of labors in Georgia had gained for him more consideration and honor than he could have won from decades of service in Parliament or from a whole life of mingling in the society of the times. It is small wonder then that he determined to return to Georgia. He may have intended to do so anyway; but there is no indication of such an intention on his part or of expectation on the part of the Trustees that he would return, until after his very flattering reception at home.

While in England, Oglethorpe was very active indeed in behalf of the colony, responding well to the encouragement he had received from the public. In attendance on the meetings of the Trustees, he was prompt and regular. He was present at fifty-five of the sixty-four meetings of the regular corporation, and he attended thirty-four of the thirty-seven meetings of the Common Council, being surpassed in his record by only one or two of the members; and he was also frequently called on for service on committees.

He was largely instrumental in getting the Trustees to pass three laws that were destined to have a large influence on the future history of Georgia. He was chairman of the committee which prepared the laws, and it was through representations that he made that they were thought necessary. ${ }^{34}$ These laws were for the purpose of regulating the trade with the Indians in the interest of peace with them, of preventing the importation of rum into Georgia, and of probibiting the use of negro slaves within the province. They were all productive of later troubles within the colony, and they were all in some respects ill advised because not

${ }^{33}$ Wright $86,91$.

${ }^{3}$ C. R. I: 70. 
suited to the people and to the circumstances in the case; but they seemed reasonable to the 'Trustees, and doubtless Oglethorpe in urging them felt that they were for the best interests of the province. ${ }^{35}$

The powers granted him on his second trip to Georgia were very similar to those possessed by him the first time. He was given authority to divide and lay out the land given in trust for the new settlement of Frederica; he was authorized to grant licenses to persons wanting to leave Georgia; it was his business to administer oaths to the newly appointed officers of the town. In addition, he was granted the power to put the act for keeping peace with the Indians into execution. ${ }^{36}$ On the first expedition, he was authorized to appoint officers for the militia, while now he was himself appointed to train and instruct them. ${ }^{37}$ He was definitely given the right to draw bills on the Trustees, and he was the only person in the province to have this right.:3s All the notes or sola bills issued by the Trustecs had to be signed by him. ${ }^{39}$ We have noted already that he exercised on his first trip the power to draw bills, though it had not been formally given him. In a few respects, therefore, the powers granted him were more definite and implied an expectation of a somewhat extended stay in Georgia to a greater extent than when he first went out; but they were still far from comparable to the powers exercised by any ordinary governor in any of the American colonies.

The company led by Oglethorpe to Georgia in 1735 was the largest number of mere colonists that went to the province during the proprietary period. There were more than

${ }^{35}$ C. IR. I: 31 et seq.

${ }^{36}$ C. R. II : 190 .

${ }^{37}$ C. R. I: $\stackrel{298 .}{ }$

${ }^{34}$ B. 'T., Ga., VIII: Verelst to Ciuston, Dec. 2, 1735.

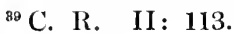


two hundred and eighty settlers in the party, occupying two ships and being accompanied by a sloop of war. Instead of going on the comparatively comfortable sloop, as he had the privilege of doing, Ogglethorpe chose to go in one of the crowded ships, paying the passage of his servants, in order that he might better take care of the colonists. He had provided himself with live stock and other refreshments for the missionaries and other companions, but he rarely ate himself anything but the ship's stores. He visited the sick on board, giving them fowls and other dainties from his own stores; and he also visited the accompanying ship as often as possible to render assistance and comfort to the pcople on it. He lectured the freeholders on the nature of the country they were to settle and told them how hest to conduct themselves in it. In all these affairs he showed a strong paternal interest in the people going with him. ${ }^{40}$

One of the first things Oglethorpe had to do upon his return to Georgia was to consult with the Salzburghers about changing the location of their town of Ebenezer. They objected to the poor quality of the land and requested to move. He objected to this; but he finally yielded the point, and they moved over to Savannah River. Later developments indicate that they rather than Oglethorpe were right in the wisdom of the movement. ${ }^{+1}$

The large embarkation that had accompanied him to Georgia was for the purpose of establishing a new town to help defend the southern boundary of the province against the'Spanish. It had been generally understood that it was to be located at St. Simons at the mouth of the Altamaha River. After Parliament granted only $\$ 10,000$ instead of the $\mathfrak{2 0 0 , 0 0 0}$ requested by the Trustees, the latter decided

${ }^{40}$ Moore in Ga. Hist. Collec. I: 85-88.

4. Ga. Hist. Collec. III: 13. 
unanimously that it would be best not to locate the new settlement so far to the south. They wished both the Highlanders and the English moved to the Ogeechee River, where provisions would be cheaper, they would be closer to Savanmah for mutual support and defence, and there would be no necessity for further Indian presents, in order to secure more land. ${ }^{42}$

A month later Secretary Martyn wrote for the 'Trustees again, urging the same policy of making the settlements nearer together. They urged that the depth of water in the Altamaha is not sufficient to make it a good harbor, and that was a main dependence in going there. In spite of the expense already met with, they preferred to drop the scheme. They yielded their judgment so far as to allow him to continue the settlement if it seemed necessary to keep the Spanish from thinking that the English were weakening in their claims to Georgia. ${ }^{+3}$ Oglethorpe evidently regarded it as best to hold to St. Simons as an outpost, and so he continued to settle and to fortify it. As a military leader, it was almost inevitable that he would make this choice, for the mouth of the Altamaha was undoubtedly a better strategic position than any point on the Ogeechee; but it is not certain that his military training was of great value to the colony in this particular decision.

There are several reasons for thinking that he made a mistake in thus going counter to the expressed will of the Trustees. As they had written him, it was very expensive to establish the new town so far from Saramah; transportation of provisions was a constant drain; the interchange of messages meant an additional outlay of money; and at the same time the resources of the Trustees were decreasing.

${ }^{43}$ B. T., Ga., VIII : Martyn to Oglethorpe, May 10, 1736.

${ }^{43}$ Ibid., June 10, 1736. 
Again, the distance from Savamal prevented Oglethorpe from kecping up with affairs in the northern part of the province; and, as the Trustecs trusted to him for letters of information, they were led into grave crrors, as we shall see. The settlement of Frederica was of no material bencfit to the colony; the town was prosperous for a little while, but it soon became practically dead. The settlements on the Altamaha were designed as defences for Georgia; but it is by no means certain that they were not sources of more danger than aid. The Spanish made no overt attempts against Gcorgia and no very vigorous protests against the English settlements there until after the settlements on the Altamaha and on the islands even to the mouth of the St. Mary's River. There is no reason for thinking that they would have disturbed the province at all if it had not been for the warlike aggressiveness of the English in establishing forts far below the charter limits of the colony. It is true that in 1742 the fortifications on St. Simons Island were of immense value in repelling the Spanish invasion; but if the settlement had been on the Ogeechee near Savannah, it is probable that no invasion would have been made. Granting, however, that an invasion would have taken place, we are confident that the same expenditure of money and labor in fortifications would have been sufficient to repel the enemy at the mouth of the Ogeechce or at Savannah itself. If all the efforts of 1735 had been concentrated in the northern part of Georgia, so great an impetus could have been given to it that it would have sueceeded from that time instead of going down rapidly as it did after that time. Oglethorpe's aggressive measures toward the Spanish may have been partly due to his slight regard for their military ability and his hostility toward them which he unconsciously gained during his service in the War of the Spanish 
Succession.

The 'Trustees did not approve of expenditures on his part for military or any other purposes outside the charter limits of the province; and they wrote to him that he must look to the British government and not to them for reimbursement for expenses thus incurred. ${ }^{44}$ This is the first intimation we have of a difference of opinion between him and his fellow Trustces that was ultimately to become serious. Oglethorpe was on the ground and he saw work that he thought necessary for the protection of Georgia; and so it seemed to him unreasonable that the home authorities should grudge to have the expenses encountered. On the other hand, the Trustees found it much more difficult to raise funds to support the colony than Oglethorpe realized; and they thought it rash for him to make expenses of which they had had no notice and for which they had made no provision.

In addition to the settling of Frederica and the establishing of fortifications on the islands along the coast, Oglethorpe had other things to occupy him. He succeded in making a treaty with the governor of St. Augustine and another with the council of war of the same place, whereby peace was to be maintained between Georgia and Florida, ${ }^{45}$ but these never went into effect for they were vetoed by the Spanish authorities at Havana. He also attended a meeting with representatives of South Carolina in order to confer with them in regard to disputes over the enforcement of the rum act. The conference was held in Savannah, and the matter was thoroughly discussed, but no agreement was reached; and it was finally carried for decision to the Board of Trade. ${ }^{46}$

\footnotetext{
${ }^{4}$ B. 'T., Ga., VIII: Martyn to Oglethorpe, July $7,1736$.

${ }^{45} \mathrm{C} . \mathrm{R} . \quad \mathrm{I}: 266$.

${ }^{46}$ Jones "IHist. of Ga." I: $253-255$.
} 
The complaints filed by South Carolina against Georgia made the Trustees fearful that they might not obtain a grant from Parliament during the next session. This anxiety was intensified by the faet that they had not heard any news at all about the province from June to November, and so they could not present any favorable statement as to its condition. In order to answer the complaints and to get the necessary news, it was deemed needful that Oglethorpe return in person, as he alone was depended on to furnish information. Accordingly the Trustees requested thist he come at once to England, ${ }^{47}$ and he embarked on his mission November 29, 1736, after being in Georgia on this visit a little less than ten months.

On January 12, 173\%, he attended a meeting of the Trustees and laid before them his proceedings in Georgia since going there the February preceding. A resolution was passed congratulating him on his safe return and thanking him for his many and important services to the colony of Georgia. ${ }^{48}$

In England he attended the hearings before the Board of Trade relative to the disputes with South Carolina, the results of which are given later; and he was greatly interested in getting the British government to take over the defence of the province, relieving the Trustees of this responsibility. This course was finally adopted; and it was determined to raise a regiment of six hundred men for Georgia. Oglethorpe himself was appointed colonel of the regiment; and he was also nominated captain-general and commander-in-chief of the forces of South Carolina and Georgia. ${ }^{49}$ Up to this time, he had drawn no salary for his

${ }^{47}$ B. 'T., Ga., IX, Oct. $22,1736$.

${ }^{45}$ C. R. I: $266-267$.

${ }^{49}$ B. T., Ga., IX: Verelst to Causton, May $27,1737$. 
services in the colony. ITe hatd been in the service of the Trustees and not of the Crown. Now he would draw the regular stipend of a colonel in the British service; and it seems that he drew in addition a thousand pounds per annum hitherto allowed the governor of South Carolina as commander-in-chief of the forces of that province. ${ }^{50}$

As a natural consequence, from this time forth Oglethorpe was more and more occupied with the matter of defence, and he could give a proportionally smaller time to the business affairs of the 'Trust. The tendency toward preoccupation with defence is reflected in his attendance on the meetings of the 'Trustees while he was at home. He was present at only thirty-nine out of sixty-four meetings of the corporation, and at nineteen of twenty-cight meetings of the Common Council. Before he went to Georgia the first time, his attendance was ninety per cent.; on his return to England it was still about eighty-eight per cent.; while on the second stay at home it was only sixty-three per cent.

On this trip to Finglind, Colonel Oglethorpe's accounts were audited; and it was found that he had kept careful accounts, for he had vouchers for all but st6t of the large sums that had passed through his hands.".

Since the notes or sola bills issued by the Trustees had been so drawn that only Oglethorpe could issue them, and that he could do it only when in Georgia, the form was now changed to enable him to issue them anywhere. He was desired to issue quite a number of them in blank so that they could be sent to Georgia for use by Messrs. Stephens, Causton, and Parker as need should develop. Oglethorpe was to be indemnified against the sola bills he endorsed; and the three officials in Savimnah would have to account for them."

${ }^{50} \mathrm{C}, \mathrm{R} . \mathrm{V}: 66$. 62 Ibid., I I : $23 \%-238$.

"1. I.. II : 244 . 
This was another step in the separating of Oglethorpe from the active management of the colony. Before this all expenses were to pass under his eye, while after this he would have little knowledge of the ordinary expenses.

This tendency, however, was not continuous. Oglethorpe gave as undivided attention to the civil affairs of the colony for a while after his return to Georgia in September, 1738, as at any time during his connection with it. There had never been any adequate executive authority in Savannah; and, after the settlement in the southern part of the province was made, not even Oglethorpe's influence was felt to any degree. Thomas Causton had exercised almost despotic power, and he had gotten the finances of the colony into a most deplorable condition. By order of the 'Trustees, he was arrested by Oglethorpe and held under bond until the matter could be investigated. ${ }^{53}$ Affairs seemed in such desperate straits that Oglethorpe felt called on to pledge his personal credit to insure a feeling of confidence on the part of the people. He offered to advance to the Trustees the income from his estates and his salary for the year. ${ }^{54}$ They appreciated his work and expressed their feelings to him on several occasions. On February 3, 1739, Accountant Verelst wrote, "The Trustees are sensible of the difficulties you labor under and the dangers you are exposed to; . . . They much approve of your conduct under these hardships and are truly animated with a most commendable zeal for the preservation and welfare of that province which you have endured so many fatigues, and gone through so many eminent dangers in the establishing of." 55 Later they express appreciation also for the generous advances of money with

${ }^{53}$ C. R. II : 247 .

${ }^{54}$ B. T., Ga., XXI: Oglethorpe to Trustees, Oct. 19, 1738.

${ }^{65}$ Ibid., Verelst to Oglethorpe, Feb. 3, 1739. 
which to finance the colony, and they promise to reimburse him as soon as the accounts could be presented to them, but they urge that he do not run beyond the computed rate of expenses." It is evident that they fear that one who is so generous with his own money may be too much inclined to spend freely the money of others which he had in charge.

A service of quite a different sort was performed by him in his visit to Coweta in order to meet with the Creek nation, obtain new land grants from them, and renew the treaty of peace and friendship. The long journey of five hundred miles through the wilderness was successfully made, and the objects of the trip were fully realized. ${ }^{57}$ Colonel Oglethorpe was a master hand in winning the confidence and support of the red men; and his services were especially important just at this time, as the war with Spain was imminent.

Toward the close of 1739 there developed a somewhat serious disagreement between Oglethorpe and the Trustees as to the amount of authority he was to exert in Georgia. On July 4, 1739, the Colonel wrote to the Trustees that things were in bad shape in the province. He represented that magistrates generally were using their powers to get income for winking at those who disobeyed the laws or they expected large allowances for doing their duty. They were banding together to allow persons to escape who were indebted to the Trust. There was a general need of a more steady way of doing things, but the people were denying that he had authority over them. He also strongly opposed any changes in the land laws, urging that those who complained in the matter were those who made the least improvements as things were. ${ }^{58}$ He made it plain that he felt

${ }^{5 n}$ B. T., Ga., XXI: Verelst to Oglethorpe, June 11, 1739.

${ }^{67} \mathrm{C}, \mathrm{R}, \mathrm{V}: 226$.

${ }^{59}$ B. 'T., Ga., XXI: Oglethorpe to Trustees, July 4, 1739. 
that he ought to be allowed to take affairs in hand and to straighten them out; and the Trustees understood perfectly well his meaning, but they were not inclined to yield to him.

They agreed with him that a steady and regular manner of doing things ought to be observed, but they said that this would result best from a faithful performance of the commands of the Trustees. First of all, the estimate of expenses ought to be carefully considered and ought not to be exceeded. All funds misapplied are at the peril of the officials neglecting or disobeying in the matter. They seem to doubt somewhat the charges he makes against the officials in Georgia, asking him to make specific and personal charges. 'They regretted that the people denicd authority in him. They declared that such must belong to the factious element of the settlers. The wiser part must understand that he neither could nor would exceed the power given him by the Trustees who would uphold the powers flowing from themselves. They likewise did not agree with his advice concerning the changes in the land laws, admitting that the complainants made little improvements, but thinking that this was due to discouragement in regard to the laws. ${ }^{59}$

At the same time, Oglethorpe was sent a report of the Committee on Accounts to whom had been assigned the duty of checking up his accounts recently submitted. The report made a number of criticisms as to the Coloncl's policies and expenditures. For instance, it criticized him for hiring men to work when there were so many Trust servants in the colony; it seemed unreasonable to the committee that he should purchase posts when the servants could so easily cut them; it appeared unnecessary to purchase cattle when there were more than a thousand head in the province; and lastly that reccipts for a number of expenditures did not appear, ${ }^{59}$ C. R. V: 267-268. 
though the committee did not doubt that they had been properly expended. ${ }^{60}$

'The letter as first prepared by the Trustees was harsher than the one sent as summed up above. It was softened by the Earl of Egmont, but still it was severe enough to much displease Colonel Oglethorpe. The Trustees felt that he wanted to act in all things at his pleasure and to spend whatever money seemed to be needed, while they felt seriously the need of strict economy; they thought also that he wrongfully applied some of the Trust money for defence that ought to have been looked after by the general government of Great Britain. They had been following almost absolutely his advice in regard to the regulations they would pass for the provinces; and now they felt that he had made mistakes in regard to several matters. He had always advocated maintaining strictly the original provisions as to land tenures, rum, negroes, and Indian trade; and he had advocated not yielding to South Carolina in the quarrel between the two colonies. They were ready to break away from his advice in regard to land and the South Carolina quarrel, as they were soon to do in other respeets. ${ }^{61}$

The next month the Trustees arranged that the sola bills which were used for money in the colony should be endorsed by three of the officials in Savannah. Up to this time, Oglethorpe alone had had this power. Now he was totally excluded from handling the money, though he could still make accounts subject to approval by the Trustees. The Earl of Egmont in commenting on this exclusion of the Colonel nentioned that it "was thought a prudent and necessary step." 62 "They also requested him through their accomptant

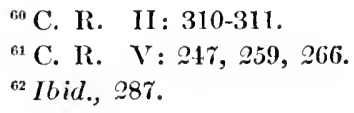


that he would be careful to distinguish in his expense accounts between items that pertained to defence, which would be paid from the British treasury, and those that belonged to the strictly civil affairs for which the Trust was responsible. ${ }^{63}$

One or two other incidents may be cited showing a slight irritation between Oglethorpe and the home board. In May, 1740 , the latter learned that the General had employed a jailer and provost-marshal at Savannah and that he had disposed of certain Trust servants. Both of these things had been done without leave of the Trustees and without informing them of the matter; and they were displeased at the occurrences. ${ }^{6 t}$

Again in the same year, the Trustees felt that Oglethorpe was acting without his authority and without reason in withholding from the people a deed poll that had been sent over in 1739. This related to certain indulgences granted by the Trustees to the settlers in regard to the land tenures. Notice of the grants had been sent to Secretary Stephens at Savannah, and the people were expecting the deed; but Oglethorpe did not like the regulations, preferring to stand by the original rules, and so it was claimed by the Trustees that he wilfully kept back the deed, to the discouragement both of the people and of the Trustees. ${ }^{65}$

On December 17, 1740, through their accomptant they wrote to the magistrates at Savannah that they did not desire General Oglethorpe to interpose in their eivil concerns while he was employed in his military ones, which were distinct services. They expeeted their orders to be obeyed by those to whom they might be sent without giving the

${ }^{a 3}$ B. T., Ga., IX: Verelst to Oglethorpe, June 11, 1740.

${ }^{64}$ C. R. V: 316.

${ }^{*}$ Ibid., 211 . 
General the trouble of being consulted and without waiting for his directions therein, which the 'Trustees did not expect from him nor reasonably could. ${ }^{\text {if; }}$ This was not liked by General Oglethorpe, but it was judged most necessary by the Board of 'Trustees for the General was too far away and his mind was too much occupied with military concerns to attend to matters in the northern part of the province. ${ }^{67}$

The situation had not been formally discussed in the meetings of the 'Trustees, so far as the records show, until December 19, 1740, two days after the letter just mentioned had been sent. On that day Mr. Vernon, a personal friend of General Oglethorpe and one of the staunchest supporters of the province, took advantage of a full board to express his sentiments on the conditions in Georgia. He frankly said that some one ought to be given more power and authority than any one in the colony had under the existing constitution. The change was imperative in order to get the orelers of the Trust obeyed. He pointed out that Oglethorpe was neglecting certain things that he had been asked to look after. He was assuming too much authority, expecting that no compliance should be given the 'Trustees' orders until confirmed by him. The Trustees had already removed him from the financial affairs of Georgia, and it was now time to remove him from the other civil concerns. ${ }^{68}$

At the next meeting of the 'Trustees, Mr. Vernon again brought up the matter, saying that much disgrace and mischief had befallen both the Trustees and the colony by reason of Orgethorpe's intervention in the execution of the commands sent to Georgia. He instanced the case of the light house which they had asked him to look after in vain, and

${ }^{63}$ B. 'T., Ga., X: Verelst to Oglethorpe.

${ }^{67}$ C. R. V: $290-991$.

${ }^{68}$ Ibid., 413. 
which would probably cost $£ 1,500$ to repair when it ought not to have cost over $£ 200$. He declared that matters of the utmost importance were delayed in order that he might be consulted because there was a misconceived notion that he had the final control of matters ordered by the Trust. On this ground, information in regard to the colony had been delayed; and yet it was of vital importance in order that the province might be set in the best light before Parliament. He proposed to invest some one in Georgia with powers superior to any possessed there at that time, and to make him entirely independent of General Oglethorpe. He did not wish a gorcrnor, proposing instcad that the province be divided into two counties with a president over each. He suggested that Oglethorpe might be complimented by making him president in the southern division. All present scemed to approve his ideas, and he was asked to embody them in a definite plan. ${ }^{69}$

Turning now to Georgia, we may understand why General Oglethorpe was neglecting somewhat to look after the light house and other affairs that had been committed to him on the civil side. As soon as he returned from the visit to the Creck nation at Coweta, he heard that war had been declared between England and Spain; and he at once began to make active preparations for it. From that time till he left Georgia in 1743 , he was occupied nearly all the time with military cares. In partial justification at least of the expenditures complained of by the Committce of Accounts, it may be noted that the English government was very grudging at times of the financial aid it lent General Oglethorpe for defending the province and for prosecuting the war; and so he felt constrained to get it elsewhere trusting that it would be later repaid. He advanced large sums for ${ }^{69}$ C. R. V: 415-416. 
the purpose himself, and he used some of the Trust money in the same way, violating his instructions no doubt and yet feeling that it was necessary. ${ }^{\text {io }}$

No detailed account ean be given of his expedition into Florida. It may well be doubted whether his service in this particular was of value to the provinee. He did not suceed in securing and holding the cordial assistance of South Carolina or of the British fleet; and so the expedition failed, in spite of his own earnestness and activity. It might be argued with some plausibility that his taking the offensive in this campaign prevented the Spanish from invading Georgia; but it seems more likely that this provocation and the fact that the English were not very successful led to the Spanish invasion in 1742 .

The repelling of the Spanish in the latter attempt was the high water mark of his career, and it was of gemume service to Georgia. He drove off a superior force of the enemy by a stratagem that was well conceived and well executed. The strictly military features of the campaign reflect little credit on him, for they were insignificant; but the general results were very important, as much so as if a decisive battle had been won by the English, since the Spanish retired to trouble Georgia no more during the remainder of the proprietary period. In this campaign, as in the former one in Florida, General Oglethorpe was acting as an officer in the British regular army; and, while his services affected Georgia, he was not acting in any capacity as a Gcorgian or as an official of the provinee.

For his bravery and good service in repulsing the enemy, the King of his own accord promoted Oglethorpe to be a Brigadier General. ${ }^{71}$ He was much troubled, however, about

\footnotetext{
${ }^{70} \Lambda$. W. I. XXV: $175,186$.

${ }^{71} \mathrm{C} . \mathrm{R}, \mathrm{V}: 679$.
} 
the state of his accounts with the treasury department; and so he sought leave to come to England for the purpose of settling the financial difficulties and of answering several charges that had been preferred against him. On July 23, 1743 , he left the province never to return. He was easily cleared of the charges against him; and he held the command of his regiment in Georgia in name at least until it was disbanded in 1748 .

Resuming our study of his relations to the Trustees after 1740, we find that in spite of his exclusion from civil affairs he could not refrain entirely from interfering to some extent; and this was still resented by the Trustees. Toward the close of 1741, the General wrote to President Stephens at Savannah signifying his pleasure that a certain lot in $\mathrm{Sa}$ vannah be granted to one Papott; but the President and Assistants overruled the request, assigning to him their reasons therefor. ${ }^{2}$ About four months later, he wrote them that notwithstanding the reasons given by them his request might and ought to be granted; but they again denied his authority to direct their action by refusing to accede to his proposal. ${ }^{73}$ At almost the same time that the above request was made by Oglethorpe, he wrote another letter to President Stephens signifying his pleasure that certain money sent to the colony by the Trustees should be turned over to an agent he was sending to receive and apply it. The Trustees had already given directions as to the application of the funds; and the President and assistants in this matter also denied the request of the General, directing that the President "do pursue his first orders received from the Trust without variation therefrom." "7t

\footnotetext{
${ }^{73}$ C. R. VI: 16.

${ }^{73}$ Ibid., 29.

${ }^{7 *}$ Ibid., 16 ,
} 
On June 18, 1742, the Earl of Egmont received a letter from lim, possibly written in consequence of the above incidents. In this letter he said that Colonel Stephens and every one in the magistracy in Georgia ought not to act without bis directions since they plunged everything into a strange confusion. ${ }^{75}$

It is probable that he tried to exereise again some authority in the southeru part of the province at least; for on May 10, 1743, the Trustees wrote to Bailiff Hawkins, of Frederica, on the subject. They expressed astonishment that any one should think that General Oglethorpe, because a Trustee, was vested with power superior to that of a magistrate. They asserted that no single Trustee had any power at all, and they further said that no single person had any power except what had been given by the collective body of 'Trustees. No single individual had power at all. The opposite doctrine would cause endless confusion. General Oglethorpe himself would set him straight in that matter. ${ }^{76}$ The Earl of Egmont explained that this letter was sent beeause Oglethorpe was interposing without authority and was looked upon by some as having a power superior to that of a magistrate. ${ }^{77}$

After General Oglethorpe reached England, though fresh from a victorious campaign that had saved Georgia from invasion, he was not received and thanked as on the former visits he had made to England. There was certainly less cordiality between him and the general body of the Trustees, to whatever cause the lack of harmony may be attributed. He attended the meetings of the board and of the Common Council with much less regularity, going to thirty-four of

${ }^{75}$ C. R. V: 637 .

${ }^{76}$ B. 'T., Ga., X : Martyn to Hawkins, May 10, 1743.

${ }^{77}$ C. R. V: 689 . 
the one hundred and three meetings of the former, and to nine of the twenty-six Council meetings, held after his return to England. His attendance before he left for Georgia the first time was, as we have seen, about ninety per cent. of the possible meetings; and it was sixty-three per cent. on his last trip; while now his attendance had fallen to thirty-four per cent. In the beginning, he had been on almost every inportant committee, while after his final return to England he was not appointed on any committee of the Common Council and on only two of the general Board of Trustees. ${ }^{78}$

His lack of harmony with his associates is shown even more strikingly perhaps in the dissent which he several times entered to matters passed in the meeting. It was one of the two general by-laws adopted by the Trustees that any member who dissented from a resolution should have the privilege in the same meeting of entering the simple words, "I, A. B., do dissent from the foregoing resolution." 79 With the exception of a single instance, Oglethorpe was the only Trustee who availed himself of the privilege of thus putting his opposition on record; and it may be worth while to note the matters on which he thus differed from his colleagues. On January 19, 1745, steps were taken to abolish the town court of Frederica, the action being partly due to the fact that two of the three bailiffs had come to Englind on military business. At the same time, a motion was made to prohibit any one in military employment from being employed as a magistrate in Georgia. The matters were postponed for final settlement; but the General desired leave to dissent from all the resolutions. ${ }^{\text {so }}$

${ }^{78}$ C. R. I: 501,510 .

${ }^{79}$ Ibid., 31.

${ }^{80}$ Ibid., 463. 
On January 30 following, the subjects were again discussed; and it was decided that if any of the magistrates of Georgia should accept military employment they would become incapable of holding or exercising their civil offices. It was further decided that dormant commissions be sent over for men to take the places of any magistrates who should thus change to the military service. As might have been expected from his former action, Oglethorpe dissented from the resolutions. ${ }^{\text {s }}$

Again on May $2 \pm$ he dissented from the proceedings of the day. On this occasion, the principal point under discussion was the distribution of Indian presents by a joint commission from South Carolina and Georgia. ${ }^{82}$ In expressing opposition to this plan, he may have been moved by his early hostility to making any concessions to South Carolina in regard to the Indian trade, for we have noted that he was persistent on that subject. On the same day, he presided at a neeting of the Common Council and dissented likewise from the proceedings of the day. It is very difficult to see any reason for his behavior on that occasion. Only routine matters were passed upon, and nothing involving any disputed principle was seemingly discussed or put through. ${ }^{\text {s3 }}$ This was the next to the last meeting of the Common Council that he attended, and it was only a short while until he stopped attending the meetings of the general board. So far as the records show, his last meeting with the Trustees was at the anniversary sermon on March $16,1749 .{ }^{\mathrm{st}}$

During the remaining years of the 'Trust, Oglethorpe was in England and was taking an active part in Parliamentary

\footnotetext{
${ }^{s 1}$ C. R. $1: 164-165$.

${ }^{83}$ Ibid., 516.

${ }^{83}$ C. R. II : 489.

${ }^{84}$ C. R. I : 529.
} 
affairs ${ }^{\mathrm{S} 5}$ and of course it is interesting to ascertain why he did not keep up his connection with the affairs in Georgia. His regiment was disbanded in 1748 , and that severed one connection that he had had with the province. We have noted also that he was not in accord with several of the measures being adopted at that time by the Trustees. There was one other circumstance that may help to explain his absence from the councils of the Trust. He was having a disagreement with the 'Trustees in regard to financial matters. Late in 1744 he was asked to render an account of the various orders for money or other articles given by him to Thomas Causton, ${ }^{56}$ and there is no record of any settlement as to that.

On July 6, 1751, the accomptant was instructed to call on General Oglethorpe for the balance due from him to the Trust of about one thousand four hundred and twelve pounds, because the money was urgently needed for carrying on the colony. ${ }^{8 \pi}$ The General replicd that the balance of accounts was in his favor, and that even if that were not true the claim of the Trustees on him was not payable until the account was allowed at the government treasury on the auditor's statement of it. 'To this the Trustees replied that he was mistaken as to their claims not being payable; he had been allowed enough from the treasury department to repay the money of the Trustees which he had used for the military service, and the Trust is in great need of money to carry on the colony. ${ }^{8 \mathrm{~S}}$

Oglethorpe responded to this request with a letter dated August 17, 1751, in which he reiterates his claim that the

\footnotetext{
${ }^{85}$ Wright 363-370.

${ }^{86}$ C. R. II: 441 .

${ }^{87} \mathrm{C} . \mathrm{R}, \mathrm{I}: 563$.

${ }^{88}$ Ibid., 565-566.
} 
balance of accounts as already submitted is in his favor. Besides, he says that there is an additional account of expenditures made by him for the Trustees which he has not yet presented, owing to the fact that he had an account to pass with the Govermment at the time it would ordinarily have been submitted to the Trust. He abstains from presenting it until the Government matter is settled when his claims and those of the Trust may be set one against another. Under date of a week later, the Trustees reply, expressing great surprise that he had any further demands to make upon them. They are the more surprised because he was present on the 17 th of January, $17+9$, when his accounts were delivered, examined and determined, and at that time he had made no mention of anything further. They, therefore, request that he let them know what these demands are as soon as possible, the circumstances of the Trust not admitting of any delay. ${ }^{89}$

This was the last communication that passed between the General and the Trustees, so far as the records show. The accounts of the 'Trust do not indicate that he ever paid any money to extinguish the claims against him, nor, on the other hand, do they indicate that he received anything in consequence of his claims. It seems most probable that the claims remained unsettled until the Trust was dissolved.

Reviewing the whole connection of Oglethorpe with the province of Georgia, we are led to a number of interesting conclusions. His personal character was worthy of admiration. Though it was bitterly assailed by many of his enemies, both on general and specific charges, ${ }^{90}$ nothing un${ }^{*} \mathrm{C}$ C. R. I: $\mathrm{I}: 566-56 \%$.

${ }^{n}$ In a number of pamphlets like the "True and Historical Narrative" (Ga. Ilist. Collec. II : 163 et seq.), he was bitterly assailed. Also by Rev. William Norris and others at the Parliamentary inquiry. (C. R. V: 573, 619.) 
worthy or dishonorable was ever proved against him. In the begiming of the enterprise, he showed only the most disinterested and philanthropic motives, and at no time during his connection with it did he seem to act from purely selfish incentives. In his first visit to Georgia, he must have been actuated primarily by the desire to aid those who had been oppressed and to show them how to succeed in their undertaking. On his later journey the same desire to be of service was doubtless present also, though it was mixed with personal ambition. He was generous in his gifts of labor and sacrifice for the colony. His contributions in money as shown in the receipts of the Trustees, were small, ${ }^{91}$ but his services were given freely to the 'Trust, 92 and at times he even paid his own expenses. He has been highly eulogized because he did not accept pay from the 'Trustees and did not acquire any lands in Georgia, but we have already noted that the charter forbade him to do either. ${ }^{93}$

As to his official career in Georgia, in spite of his high aims, his pure motives, and his clean character, he did not meet with very great success. He started out on the friendliest terms with South Carolina, but it was not long until that province was completely alienated from him. Of course this was not entirely the fault of Oglethorpe, but in the matter of the Indian trade and in regard to the expedition to Florida, he did not seem to use the tact that was needful to get the best results. Whether another could have succeeded better is of course an open question, but there was no difficulty with the colony after President Stephens took

${ }^{21}$ They amounted to about sixteen pounds. (C. R. III : $\%, 14,164$.)

${ }^{92} \mathrm{He}$ was paid nothing at all until he was made colonel of the regiment and commander-in-chief of the forces of South Carolina and Georgia, when he received abundant pay from the government, though nothing at any time from the Trustees.

${ }^{83}$ C. R. I: $16,21-22$. 
charge of the Indian affairs for Georgia. On the whole, his relations to the civil affairs of the province were not entirely advantageous. Retaining all authority at first, he made the impression, whether intentionally or not, that the magistrates were to be subservient to his will and that no important action was to be taken without his consent. This caused rexatious delays when he was out of the provinee or too far away to be readily reached; it was also a source of misunderstanding and hard feeling between him and the Trustees later on. 'There was no settled way of doing things in Georgia until the Trustees made it plain that their directions were to be fully carried out without consulting him.

As long as his advice was followed regarding the land tenures, the introduction of rum, and the prohibition of negro slaves, the colony was kept backward. In theory he seemed to be right on all those matters, but, as Burke observed, the regulations were not adapted to the country and to the people coneerned, and they could not succeed. The Trustees in England had to depend on the advice given by Oglethorpe on the field, and he erred, though in all honesty, as to what was the best course to pursue. The loose govermment and the unsatisfactory economic conditions were the prineipal hindrances in the development of the colony.

In the matter of defence he was most sucessful, maintaining peace with the Indians and keeping the Spanish out of Georgia; yet even in this matter it is not certain but that another policy might have been better. The plan of pushing fortifications and forts far to the south helped to arouse the hostility of the Spanish, and after they were established in 1735 and the following years, there was much disturbance from Spanish alarms. The people could not raise their erops and go quietly about their business. They might have been spared this anxicty if the Georgia settlements had 
been kept within the limits of the province, and especially if they had been kept in the northern part of it. However, in the actual fighting necessary to drive off the Spanish in 1742, General Oglethorpe was abundantly successful. His zeal for defence led him to make quite extensive expenditures of money which neither the Trustees nor the British government were willing to sustain. He was of that generous and somewhat reckless disposition that does on the impulse what seems necessary at the moment without waiting to weigh the expense and determine whether it is absolutely required. With his own money he was perfectly willing to make such expenditures, and so he was not likely to think it wrong to do so with that of the Trust or of the Government. 'Thus he had serious trouble himself because of his accounts, and he made trouble for the 'Trustees.

If he was unsuccessful in Georgia, he was not more to blame than the Trustees themselves, and perhaps he was not so much at fault as they. He was placed by them in a most embarrassing position, being sent to take charge of the colony and yet clothed with most insignificant powers. He could accomplish little if he stayed within his commission from them, and if he exceded it he was open to censure, especially if his transgression proved troublesome in any way. They gave him very few instructions, but they were ready enough to expect that he act wisely without them. If he could have been appointed a regular governor of the provinee, with powers similar to those of the governor of South Carolina or of other provinces, and with sufficient assistants to help him, he would no doubt have made an excellent record in most respects, but the Trustees were unwilling to surrender much power to any one in the colony, and no member of the Trust could fully occupy the position of governor on account of the charter provisions. 
Therefore in our judgment it would have been better for the provinee if Oglethorpe har never gone to Georgia, or at least if he had gone there, only as the commander of the regiment and without any civil authority at all. Of course his help at the outset would have been greatly missed, and the first year might not have been so sucessful as it was. If Oglethorpe had not gone, however, it would have been necessary for the 'Trustees to send some other person of experience and ability to manage the expedition, as it could not have been trusted to the raw colonists themselves. Such a person would have been responsible to the Trustees, as Oglethorpe was not; from him they could have required frequent and regular reports, as they did not feel free to require of Oglethorpe and as they did not get from him. Such a person, whether actually bearing the title of governor or not, would have had centralized authority to some extent, and he would have been steadily in the province, whereas Oglethorpe did not feel bound to remain there and did not actually reside in Saramah, the central place of government, more than one year out of the ten that he was connected with the province. 'The Trustees would have felt it necessary to send full instructions to such an official, as they did later to President Stephens, while they expected Oglethorpe to know what to do from his general knowledge of their purposes, and greater definiteness and certainty were much needed in the colony.

If the Trustees had been compelled thus to appoint a governor, they might have put themselves into more cordial relations with the Board of 'Trade and the ministry in England, and so might have been aided rather than injured by the suggestions from these sourees, as they feared they would be.9t

${ }^{9} \mathrm{C}, \mathrm{R}, \mathrm{V}: 415-416$. 
It is unlikely that any person could have been found who had the natural qualifications and the enthusiasm possessed by Oglethorpe, and therefore so fit to be a governor, but whatever he lacked in personal fitness and zeal might be atoned for by the other advantages mentioned above. If Oglethorpe could have remained in England he would have made a most useful member of the Trust, punctual in attendance, ready to work, successful in getting outsiders interested. He might thus have served the colony as faithfully, if not so prominently, and during the closing years he might have been still cordial with his associates instead of absenting himself from their meetings, dissenting from their actions when present, and lisputing with them as to the balance of money due on his accounts with them. 


\section{CIAPTER IV}

TIE EXEGITIVE IN ENGIANI)

T' has been made evident in the preceding chapter that Wames Oglethorpe did not possess plenary powers in Georgia. All through his eareer in the provinee he was directed and restrained by the Trustees in England, and we have seen that they gradually removed from him the powers which he at first exereised. 'This governing body in England jealously preserved its complete control of the colony, and so it is important that it be studied with some care. What were the powers and duties assigned to the Trustees by the charter? What was the nature of their organization? What was the comnection between the general corporation and the Common Couneil? What were the relations of the 'Trust to the organs of imperial control in England? How was the Trust regarded by the various ministries that ruled during its existence? By what means did it secure the support of Parliament? This chapter will attempt to answer such queries, tracing somewhat briefly the principal activities of the Trustees in England. There was no idea of the separation of powers in the grant of authority given to the Trustees by the charter. The corporation was to combine in itself the exceutive, the judicial and the legislative functions of government. However, in the actual management of the provine, the executive part of the work greatly overshadowed in importance the other functions, though it is sometimes difficult to clisssify strictly all the activities of the 'Trustees. 
The Georgia charter provided for a self-perpetuating body, vacancies being filled and new members being chosen by the general membership of the Trust, but elections could be held only on the third Thursday of March between the hours of ten and four o'clock, and a two-thirds vote of those present was necessary for the election of new members. No menber of the corporation could receive directly or indirectly any salary, fee or profit whatever from his connection with it. In this respect the Georgia charter created a company entirely different from the first corporations that tried colonization in America. The first companies were founded and managed chiefly for profit, being trading companies in the strict sense; whereas in the case of the Georgia corporation all idea of gain was forbidden at the outset. A willingness to do disinterested public service must characterize those who should become its members. Not only was profit forbidden on account of being a T'rustee, but no member of the Trust was allowed to accept or hold any office or employment of profit that might be created by the corporation. ${ }^{1} \quad$ Furthermore, while land might be granted freely to all other comers, no Trustee was allowed directly or indirectly to secure by grant or even by purchase any land or interest in land in the new eolony. ${ }^{2}$ No special qualifications or restrictions were prescribed for members of the Trust, except those just mentioned--that no one holding an office of profit under the 'Trust and no holder of Georgia lands was eligible to membership in it. 'The charter made only one provision for the resignation or withdrawal of members from the corporation; in general a person once duly elected a member remained so whether he wished it or not, but the acceptance of office under the 'Trust or acquiring of interest

${ }^{1}$ C. R. I : 16 .

${ }^{2}$ Ibid., $21-29$. 
in the lands of Georgia ipso facto caused membership in the Trust to cease.

As there was a large number of 'Trustees at the beginning, and as it was intended that the number should be considerably increased from time to time, it was deemed too great a hardship that all of them should be convened as often as might be necessary for the proper conduct of the colony. Hence the charter provided for a Common Council which would have power to transact a large portion of the business devolving on the corporation. ${ }^{3}$ This committee of the corporation was at first established as a body of fifteen members, nine of whom were designated by name in the Charter, but it was provided that when the membership of the 'lrust should be increased, the Common Council should also be enlarged so as to have twenty-four members." Since it was only a committee, its members must be selected from the general membership of the corporation. They were to hold office during good behavior. It was provided that a member of the common Council could resign under his hand and seal and that the vacancy so created shoukd be filled at the ammal meeting of the T'rustees in March; but a man so resiguing his place in the Common Council was still a 'Trustee, for we have already noted that there was no means by which one might resign that responsibility. It would have been better perhaps if resignations from the corporation hat been allowed, for it was of no advantage to retain the name of a man on the roll of 'Trustees when he had lost interest in the enterprise and was perhaps even hostile to it; but it was very necessary that resignations be allowed in the Common Council, since it was limited in membership and so those commected with it should be interested and active

${ }^{3}$ C. R. I : 19-20.

${ }^{4}$ Ibid., 14 . 
men. Those chosen for the Common Council were required to take an oath for the faithful performance of the duties required. Such an oath was not required of those who were members of the corporation only. ${ }^{5}$ Possibly one reason for this distinction was that, as we shall find, the Common Council was given the sole right to dispose of the money of the Trust and this provided a responsibility not shared by the ordinary members. In order to transact business, there must be at least eight members of the Common Council present; ${ }^{6}$ but no quorum was designated for the general meetings of the Trustees. It was no doubt assumed that a nueh larger number than eight would be present; but we shall find that in practice three members frequently constituted a quorum at the Trustee meetings.

The Trustees when assembled in regular meetings were presided over by a president. The first president was desigmated by name in the charter, but his term of office was for a single meeting and until another was convened. After that, the office of president rotated among the members of the Common Council, each holding for a single meeting and for the intervening time till the next. ${ }^{7}$ No special reason appear's why the office was limited to those who were members of the Council; it was likely so provided because they were under a general oath of faithfulness that was not required of the other members of the Trust. In like manner, the Conmon Council was to be presided over by a chairman, who was in the first instance named in the elarter but was to hold office only for the same length of time as the president of the corporation. There was to be rotation in the office

${ }^{5}$ It was not at first certain that oaths were not to be given to members as Trustees as well as Common Councilmen; and they were at first so administered. C. R. I: 118-119.

${ }^{8}$ C. R. I: 22 .

'Ibid., 15. 
of chairman just as in that of president, except that any member of the Council could be chairman, while we have seen that not all the Trustees could act as President. A number of the regulations were applicable to both the president and the chairman. No one could hold either oflice twice in succession unless at the second meeting of the Trustees he should happen to be the only member of the Common council present. In case of dispute as to the order of rotation, the matter was to be settled by a rote of the members of either body present at the meeting when the question was raised. The president or chairman could discuss and vote on questions under consideration just as other members, and in case of a tie either could cast a deciding vote. Neither officer could receive directly or indirectly any fee or reward whatever for acting as president or chairman. ${ }^{\mathrm{s}}$

Having noticed somewhat the organization of the corporation and the Common Council, we shall now consider the various powers granted to each of them. As a rule, matters that were general in their nature were assigned to the general board of 'Trustees, while affairs that were more specific and minute were assigned to the Common Council, though this distinction in functions did not always hold good. In order that the eharitable oljeets of the Trustees might be carried out, it was necessary to take collections from those who were interested in the project. The corporation was authorized to issue commissions for this purpose with the power to revoke the same if it seemed best to do so, but a report of all moneys received and expended must be laid before two of the officers of the Crown each year. ${ }^{9}$

The general corporation was authorized to establish and to put into execution with sufficient penalties all such by-

${ }^{8}$ C. R. I : 15-16.

${ }^{9}$ Ibid., 17. 
laws and ordinances as might be necessary for the governing of the corporation, and these might also be repealed or altered by a majority vote at any meeting; but such bylaws and their penalties must be reasonable and not repugnant to the laws of the realm. Morcover, such by-laws or alterations must be reported and approved at the annual meeting of the Trustees in March.

The power to hold lands or other property in Great Britain and the grant of lands in Georgia were both made to the general board of Trustees. ${ }^{10}$ So also the making and enforcing of laws, ordinanees and statutes for the governing of the colony was committed to the same body, and it was provided that such laws must not be repugnant to the laws of the realm and that they must be submitted to the king in council for approval before they could be effective. ${ }^{11}$

To the Trustees as a body was entrusted the power for twenty-one years of establishing courts of records and other courts in Georgia for hearing and determining all manner of crimes, offenses, pleas, matters, eauses and things whatsoever arising in Georgia, whether the erimes be capital or not, and whether the pleas be real, personal or mixed. These courts were to have the usual power to administer oaths for the discovery of truth in matters before them. ${ }^{12}$ The general corporation also was given the power to train the militia of the province, to take all offensive measures that might be necessary for the safety of Georgia, and to declare martial law. ${ }^{13}$

The Common Council was endowed with large powers.

${ }^{10}$ C. R. I : 12,18 .

${ }^{11}$ Ibid., 19.

${ }^{13}$ Ibid., 29.

${ }^{13}$ Ibid., 21-25. 
It was given full power to expend and apply all money and effects of the Trust in such manner as might seem to it most advantageous. It could in the name of the corporation enter into contracts or other covenants comnected with the purposes of the corporation. It was the duty also of the Conmon C'ouncil to choose and appoint treasurers, secretaries and all such other officers or servants as might be needful for the efficient management of affairs in England. It should fix the salaries to be paid such officials, should administer oaths of office to them through the chairman, and should remove them at pleasure. Such appointees would of course be debarred from membership in the 'Trust. ${ }^{14}$

It was the power of the Common Comncil to make all grants of land in Georgia and to specify the terms and conditions of such grants, except it could not, as we have seen, alienate any land to a Trustee, and it could not make grants of more than five hundred acres to any one person. ${ }^{15}$ For a period of twenty-one years, it was the function of the Common Council to nominate, appoint and commission by such names and styles as might seem to it best all such governors, ministers and officers, both civil and military, both by sea and by land, as might seem necessary for the welfare of the colony, sare only such officers as might be appointed for collecting the King's revenue. ${ }^{\text {fi }}$ We have already noted that the only limitation put on this power of appointment was in the case of the governor, who must have the approval of the King and qualify himself according to the ordinary rules prescribed for the gorernors of the plantations in America.

Keeping in mind this gencral division of powers between

${ }^{14}$ C. R. I : 20 .

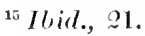

${ }^{10}$ Ibid., 24. 
the corporation as a whole and the Common Council, as prescribed by the charter, we must next examine the relations of the two bodies in actual practice. It will be recalled that the reason assigned by the charter for the creation of the Common Council was that it would be too great a hardship for the whole body of 'Trustees to assemble as frequently as the demands of the business for Georgia might require. It would seem, therefore, that the Council was merely authorized to do certain business that the whole corporation would perform if it were in session, and the terms of the charter do not indicate that it was to have exclusive jurisdiction in the matters over which it was given control. The word used to describe the scope of the jurisdiction was "full," and by the ordinary rules of interpretation it would not mean "exclusive." It was not so construed by the Trustees themselves at first. For example, the corporation as a whole made agreements ${ }^{17}$ and directed expenditures during the first year of its existence, ${ }^{18}$ but the interpretation that all such powers belonged only to the Common Council prevailed, and so the actions of the general board in those particulars were expunged from their minutes and inserted in those of the Common Council so as to have the matter straight from the beginning. ${ }^{19}$

It is interesting to observe that the Common Council which was supposed to meet more frequently than the general board fell very far short of its purpose in this respect. During the proprictary period of twenty years it met two hundred and fifteen times, while during the same period the board met five hundred and twelve times, or more than twice as often as the committce. The explanation of this depar-

${ }^{17}$ C. R. I: $77-79$.

${ }^{18}$ Ibid., 8Q.

${ }^{19}$ Ibid., 118-119 and C. R. II: 49-50. 
ture from the intentions of the charter is found in the fact that there could be no legal meeting of the Common Council without the presence of eight members, one-third of its entire membership, while as few as three could do business as Trustees if one of the three was a member of the Common Council. It was assumed in the regulations made in the beginning that the board meetings would be attended by a large proportion of the members, but this was not the case even at first when there was much enthusiasm over the colony, and toward the last years of the proprietary period, though there were some fifty or sixty nominal members of the Trust, the attendance at the meetings was ridiculously small. Of the eighty meetings held during the last seven years of the period, twenty had only five members present, ten meetings had only four in attendance, and nineteen meetings had only three members to do business. The fact is that the management of the Trust affairs had devolved on onc or two persons, and they collected just enough Trustees who could be conveniently reached to make their proceedings regular and legal. The average attendance on the five hundred and twelve neetings was eight members, but there were many more times when there were less than that number than times when a larger number were at hand. The ammual meetings in March were usually well attended, and they, with such special occasions as the return of Oglethorpe from his first trip to Georgia and others of like nature which attracted a large attendance, brought the average of the many small meetings up to the number mentioned above.

The average number present at the two hundred and fifteen Common Councils was nine nembers, only one more than the minimum required. During the earlier days, the attendance was larger than toward the latter part of the period. It is surprising to note how uniformly business was 
done between 1745 and 1752 with just the required number present. The truth is that there was a great deal of difficulty encountered in getting a quorum for the Conmon Council during almost all the proprietary period. In a journal which he kept for several years, ${ }^{20}$ the Earl of Egmont sets forth these difficulties very frequently. For example, between June 9, 1738, and June 9, 1739, there were nine instances when a Common Council was called, but not enough members were present to form a quorum. ${ }^{21}$ On other occasions, members would have to come out of the country from seven to fifteen miles in order to make the quorum complete. ${ }^{22}$ When it was impossible to secure a regular meeting, and when business was pressing, the accomptant of the Trust was sometimes asked to get the signatures of absent members who could not or did not attend. ${ }^{23}$

In 1732 the general board of Trustees began its work by having a regular meeting once a week. At first Thursday was the day set for the meeting, but at the beginning. of 1733 it was changed to Wednesday, ${ }^{24}$ and that seems to have continued the stated day during the whole of the proprietary period. Of course there was not always one meeting per week, for the general average for the whole period was one for every fortnight, and there were many more proportionally toward the first part of the twenty years than toward the last. The greatest number in any one year were sixty-four, which were held between the annual meeting of 1733 and that of 1734 .

The Common Council did not begin its work by having any regular time of meeting. Even during the first months,

${ }^{20} \mathrm{C}$. R. $\mathrm{V}$ is entirely devoted to this journal.

${ }^{21} \mathrm{C} . \mathrm{R} . \quad \mathrm{V}: 3 \gamma$ et seq.

${ }^{22}$ Ibirl., 50, 53.

${ }^{23}$ Ibid., 63.

${ }^{24}$ C. IR. I: 94 , 
contrary to the plan of the chirter, it met less frequently than the general corporation. Like the general board of Trustees, it sometimes adjourned to meet at a specified time and plice, and the place and hour were usually the same as those specified for the general board.5 It was frequently the case that the same men would at one sitting transact business part of which belonged to the jurisdiction of the Common Council and part of which to the corporation. On such occasions, however, the chairman of the Council and the president of the general board were kept distinct, and usually at least the same man did not exercise both functions. ${ }^{26}$

It was assumed that convenient notice of meetings to be held would be given. ${ }^{27}$ Sometimes the summons was for a board meeting, and it might be turned by consent into a meeting of the Council; more frequently the summons would be for a meeting of the Common Council, and failure to get a sufficient number would limit the business to that of a board. Occasionally also notice would be sent of a committee meeting, and after it was assembled, business would require that it act as a general board or as a Common Council. The notice or summons was issued in various ways. Letters were sent to the members, and this was perhaps the most common method. Notices were also put into the daily papers when matters of importance were on hand. ${ }^{28}$ It is not entirely clear on whose authority the summons for meeting would be issued. It is known that the various committees of the Trustees and of the Common Council had authority to summon either body to receive reports or to give further directions, 29 and this was done through the agency

${ }^{25}$ C. R. II : 8 and C. R. I : 80 for examples.

2: C. R. V: 390 , t28, as instances.

${ }^{27} \mathrm{C} . \mathrm{R} . \mathrm{I}: 16$.

${ }^{28} \mathrm{Ilid}$., 335.

${ }^{29}$ Ibirl., 158; also C. R. V: $3 \%, 39$, as examples. 
of the secretary or the accomptant. It seems that it was not customary to summon the whole of either body for ordinary meetings; this was done only on special occasions. ${ }^{30}$ There is no way of determining how a distinction was made as to who would be sunmoned, but it was very likely on the basis of accessibility and convenience.

The place of meeting was at first in Palace Court, Westminster, and later it was in Queen's Square, but this was not definitely fixed, as meetings were held at many other places as convenience might dictate. They were held, for example, in a committee room of the House of Commons, at the private homes or lodgings of various members, and in the vestry rooms of churches. The annual meetings on the third Thursday of March were always held in the vestry of some church, usually either at St. Bride's or at St. Margaret's.

The annual meetings were occasions of great interest in the history of the 'lrust. A sermon was always preached to the Trustees assembled for the purpose, and this frequently dealt with some aspect of the work the Trustees were trying to accomplish. Either before or after the sermon, or at both times, the Trustees were assembled as a general board, and at the same time a Common Council usually met. A general report was made of the year's work. A statement of the financial condition was presented. New members of the Trust and of the Common Council were chosen, and, after adjournment, most of the members dined together at some convenient inn. ${ }^{31}$

The official year of the 'Trust was from annual meeting to annual mecting, and it will give some idea of the activity of the corporation and of the Common Council from year

30 C. R. V: $279,995,297$, as instances.

as Ibid., 134 for example. 
to year to give a table showing the number of meetings held by each body during the period of their existence. In connection with this table, it is to be remembered that the first year lasted only from June 9, 1732, to March 15, 1733, and also that the last year was incomplete, ruming from March 20, 1752, to the surrender of the Trust on June 23, 1752.

NUMBER OF MEETINGS HELI) BY TIIE GENERAL BOARD OF TRUSTEES AND BY THE COMMON COUNCIL IN EACH OFFICIAI, YEAR FROM 1732 TO 1752 INCLUSIVE.

\begin{tabular}{lcc} 
Year & Trustees & Common Council \\
$1739-3$ & 36 & 15 \\
$1733-4$ & 64 & 33 \\
$1734-5$ & 51 & $2 \mathcal{2}$ \\
$1735-6$ & 47 & 28 \\
$1736-7$ & 31 & 13 \\
$1737-8$ & 45 & 16 \\
$1738-9$ & 35 & 15 \\
$1739-40$ & 28 & 14 \\
$1740-1$ & 19 & 14 \\
$1741-2$ & 16 & 13 \\
$1749-3$ & 16 & 8 \\
$1743-4$ & $2 \mathcal{2}$ & 5 \\
$1744-5$ & 13 & 2 \\
$1745-6$ & 10 & 2 \\
$1746-7$ & 10 & 2 \\
$1747-8$ & 7 & 2 \\
$1748-9$ & 13 & 2 \\
$1749-50$ & 10 & $\mathcal{2}$ \\
$1750-1$ & 11 & 2 \\
$1751-2$ & 14 & 3 \\
1752 & 4 & 2 \\
\hline $1739-175 \mathcal{2}$ & 512 & 215 \\
& &
\end{tabular}


These figures, decreasing steadily from year to year with a few unimportant exceptions, indicate most clearly the decay in the activities of the bodies concerned. The highest point of interest was in the second ycar of the enterprise. In 1735-1736 the number of Common Council meetings increased on account of the large expenditures of money made possible by a generous appropriation from Parliament, and again in 1737-1738, when the British govermment was taking over the defence of the colony and when a regiment was being raised and sent to Georgia, there was an increase of activity on the part of both the corporation and the Council. The very noticable decrease in meetings in 1744-1745 and the years just following was no doubt caused by the continuance of the war with France and Spain, which made communication with the colony very difficult and which also precluded any liope of Parliamentary aid. Since many of the ordinary meetings were for the purpose of discussing the news from the colony and of petitioning for money, and since these two motives were much less feeble during this period, it is readily understood why the meetings should decrease. With the coming of peace in 1748 , there was more business that required attention, though comparatively little when measured by the standards of the first year or two. Most of the meetings in 1751-1752 were concerned with the preparations to surrender the charter to the Crown.

Connected with the business of making settlements on a large scale at so great a distance from England, there were of course many duties that neither the corporation nor the Common Council could look after as a body, and so we find a large use of committees in both bodies. In the records of the general board of 'Trustees, there are at least fifty-five instances where committes of one or more persons were designated for somewhat trivial matters, such as the thank- 
ing of some donor for contributions of money or effects. Most of these appointments were made early in the history of the colony, for the secretary or accomptant performed such offices during a large portion of the time. At various times, eight committees were selected to look after and report on laws or regulations necessiry for the Trust or for the colony. For correspondence with the Salzburghers or for consultation with them relative to their going to Georgia, at least twelve committees perforned duty. Members especially delegated looked after the various embarkations of colonists for America and supplied their needs for the journey. Others carried the ammal reports to the Chief Justice or other officials designated by the charter and filed reports with the Board of 'Trade or with the other exccutive offices of the home govermment. There were committees also for keeping the seal of the 'Trust, for making estinates on work to be done in Georgia, and for presenting Indian visitors in England to the king. Quite frequently it was necessary that a committee confer with the Secretary of State relative to despatches from Georgia on matters of national import. On several oecasions, committees were appointed to make an effort to have the quitrents redued, to examine accounts, or to certify various drafts. To others were assigned the very important task of getting the chancellor of the Exchequer interested in the financial support of the colony, or petitioning Parlianent for funds to assist in the work, or of seeking financial assistance from the Society for the Propagation of the Gospel in Foreign Parts. When the 'Trust was about to be dissolved for lack of support, all of its affairs were placed in the hands of a special committee for nore than a year. The foregoing list of committees only partially represents the many activities of the corporation, but it gives typical examples of the work performed by the 
general bourd of 'Trustees in this manner.

All the committees heretofore mentioned were in large measure temporary, whose duties extended only through periods of a few hours or of a few days. Far more important than any of them, therefore, was the Committee of Correspondence, which lasted, with some variations in membership, throughout the proprietary period. It was established in 1734. On February 6 of that year, a motion was made that a Committee of Correspondence be appointed, and five days later a resolution was passed creating the important committee. It was to inspect all letters coming to or affecting the Trust, and to prepare drafts of letters and other correspondence for the approbation of the Common Council or of the Board of 'Trustees. The accomptant, secretary or messenger receiving letters for the Trust would at once commit them to some member of the committee which had power to summon a meeting of either the corporation or the Common Council at will. The committee was to consist of twelve men designated by name, but any three of them could make a quorum for business. ${ }^{32}$ At a later time the committee was enlarged, ${ }^{33}$ and it played a very important part in the practical administration of the Trust affairs.

The Common Council, while itself supposed to be a committee of the general corporation, nevertheless made much more frequent use of committees than did the whole body of 'Trustees. Many of these were charged with the financial interests of the colony, of which we have seen that the Common Council had jurisdiction. The committee most frequently called to act was charged with the power of drawing on the Bank of England for Trust funds on deposit there; any five of the original fifteen members of the Council

${ }^{32}$ C. R. I: 158.

${ }^{33}$ Ibid., 242. 
were authorized to act as a committee for this purpose, and, when the number was enlarged to twenty-four members, the same rule applied. ${ }^{34}$ ('ommittees from the Common Council, as well as from the corporation, were sent to confer with the Chancellor of the Exchequer about securing support. Dealing also with financial matters, but having a more difficult task to perform than these other committees, was that on accounts. It was originally composed of ten men, any three of whom might form a quorum; the constitution of the committee was later changed so that any three of the Council could serve in this capacity. ${ }^{35}$ The accomptant relieved the committec of many tedious duties; but even with this aid, the task was very slow and difficult. When matters of peculiar intricacy arose, as in the case of 'Thomas Causton, the deposed storekeeper' of Savannal, members might again be designated by name for the service, other members of the Common Council being allowed a vote on the committee, and members of the general board who were not of the Council might also be asked to assist in the work. $^{36}$ Other appointees balanced accounts with the Bank of England and prepared reports of the yearly expenses. When it became the policy of the Trustees to pay their bills in notes or sola bills, several committees were made necessary. One of these prepared the form of the notes, another looked after their exchange at the bank, while a third cancelled and destroyed them. Another important financial committec was that charged with the duty of making out the budget or estimate of expenses in Georgia.

Next to financial affairs, perhaps the framing of regulations and the preparing of instructions for magistrates

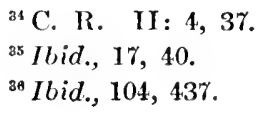


formed the most important work of the Common Council committees. On several occasions these were appointed to consider changes in the land tenures, the forms of grants, forfeited estates and other agrarian matters. ${ }^{37}$ Other committecs were authorized to prepare an act for powder duty, a sumptuary law forbidding the use of gold and silver for ornaments, an act for the use of negroes, and many regulations of less importance. The Common Council delegated members to investigate prospective magistrates and to prepare commissions or instructions for magistrates on the comparatively rare occasions when such were sent. As a general rule, the sending of instructions was in the hands of the Committee of Correspondence, and the directions were sent informally, but this committee was not of so much importance in the work of the Common Council as it was in that of the general board.

Committecs to look after trifling or petty matters were very numerous indeed, and the duties performed by them were in general very much like those of the corporation, so that it would be tedious to repeat them in detail; but towards the close of the Trust there were several important ones that we must notice somewhat earefully. On A pril 25, 1751, all the powers of the Common Council were delegated to eleven of its members and to one of the other Trustees in order to adjust with the administration the proper means for supporting and settling Georgia in the future, and to take such steps from time to time as might be necessary for the welfare of the province. The committee was empowered to framc, seal and present all such representations or memorials as might seem advisable. The whole committee or any three of its members might act as a committee of correspondence without having to submit its letters or other ${ }^{37}$ C. R. II : $38 \%, 409,485,506$, as examples. 
correspondence to either the Common Council or the corporation, and it was also given authority to audit and inspect the Trust accounts. The same committee or any five of its members were authorized to prepare the important regulations for the first meeting of an assembly in Georgia, and it could put these regulations into operation without reporting them to any other body. ${ }^{3 s}$ 'The appointment of this committee with such plenary powers was practically creating a substitute for the Common Council as designed by the charter, displacing the Council by a body with less strict requirements as to quorum. The action was probably necessary, as it was very difficult to get eight members together, and the Council was not entirely abolished, for when it could get a quorum of eight it met under its own name.

About a year after the appointment of this committee, another was named to superintend the final details of the surrender of the Trust. It was composed of nine members. It took charge of the books, pipers and effects of every kind, and any three of the committee might dispose of them as they thought best. It was also entrusted with the money to be paid by Parliament for the cancelling of certain debts of the Trust, and it was to distribute it according to its judgment as to what was proper. ${ }^{39}$

The Georgia 'Trustees were anxious to be as independent of control as possible during the twenty-one years of their political authority. They felt that only in that way could singleness of aim be secured in the management of the province. We have already noticed how they interviewed repeatedly the Board of Trade or the committee of the Privy Council before the charter was granted in order to secure the privileges they deemed essential to the proper control

${ }^{38}$ C. R. II : 506-507.

${ }^{39}$ Ibid., 593-524. 
of the colony. On the other hand, as it was the general policy of the Lords Commissioners for 'Trade and Plantations to procure a large degree of imperial control over the various British colonies, and as they were especially opposed to the chartered colonies, it is not surprising that the Trustees of Georgia and the Board of Trade did not always agree about the affairs in which they were both concerned. We have already noted that the Trustees did not appoint a governor for the province, as the charter had anticipated that they would do. Such an official would have been under the control of the Board of Trade and other executive offices of the Crown. ${ }^{40}$ By sending James Oglethorpe as an attorney for them, the 'Trustees effectually maintained their independence in that particular, though we have also seen that it was probably a mistake in policy to do this. Whether or not it was resented by the Board of Trade docs not appear, but for a considerable while thereafter the Trustees felt that the Board was not favorable to them. This feeling that the Board was hostile appears several times in the records in connection with the dispute between South Carolina and Georgia on the subject of the Indian trade. 'This dispute was brought before the Board of Trade for settlement, and several hearings on the subject were held. The Trustees claimed that the Board's partiality to South Carolina was shown before making its report in its putting certain questions to the law officers of the Crown which they refused to allow the Trustees to see, and also in its presenting a report in favor of South Carolina in spite of the fact that the law officers reported in favor of Georgia. ${ }^{41}$ The facts would be too tedious to be given here, but the action of the Lords Commissioners for Trade and Plantations can be

$$
\begin{aligned}
& { }^{40} \text { C. R. I }: 24 . \\
& { }^{41} \text { C. R. V V }: 7-8 .
\end{aligned}
$$


explained on other grounds than prejudice toward the Trustees. Their well-known policy was to encourage and promote trade, and it was no doubt in pursuance of this policy that they made their decision in the Georgia-South Carolina case. The free adnission of Carolina traders to take part in the traffic with the Indians was thought to be an encouragement to this very desirable trade, and in like manner it was thought that the promotion of this trade was a sufficient reason for allowing the free navigation of the Savannah river, even by vessels carrying rum, provided they did not trade with the Georgia settlements. ${ }^{42}$ However, the Georgia Trustees were not willing to accept the decision of the Board of 'Trade in the matter and appealed the case to the Privy Council. ${ }^{43}$ After a hearing before that body, the case was compromised, but some of the Trustees were quite dissatisfied with that result and even questioned the right of the Privy Council to reach such a conclusion that it practically suspended an act which had been passed by the Trustees. ${ }^{44}$

In 1740 the same feeling that the Board of Trade was hostile was manifested in regard to a Pilot Act which the Trustees had proposed and which had been referred to the Lords Commissioners for consideration. Referring to their action thereon, the Earl of Egmont wrote, "This Report appeared to be made with great animosity against us, but we were not much surprised at it, the Board being constantly our Enemies." 45

In the same year, Mr. Verion, another of the prominent Trustees, expressed very freely his opinion that the influ-

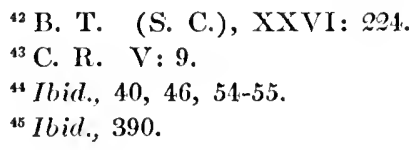


ence of the Lords Commissioners for Trade and Plantations was dangerous to Georgia, and his sentiments were approved by his fellow Trustees. He was urging the necessity of a better government in the colony, but he was suggesting that two presidents be appointed rather than one governor, because in that way they could preserve the colony to the Trustees. He argued that appointing one man would be in a measure surrendering their charter, for by its terms such a person must be approved by the King, and when he was once established in office the Trustees could not remove him at pleasure. Such a governor "would be obliged to obey not only the Trustees' Orders but the Orders also of the Board of Trade, Our Enemies, who would become our Masters, and without regarding the Trustecs and acquainting them, would send over such Orders as they pleased, which in a multitude of Cases might clash and interfere with Orders sent by the Trustees: So that no Gentleman would continue in the Trust to be rival'd, disputed with, and become subservient to the Board of Trade, who know as little of the Colony as they do of trade." 46

In 1742 an act of the Trustees allowing the importation of rum into Georgia on certain conditions was referred to the Board of Trade. It approved the general tenor of the act, as it tended to encourage trade, but it refused to report in favor of the clause which gave power to the Common Council of the Trustees to make rules and regulations for the purchase or sale of the rum, thus indicating a desire to limit to some extent at least the exclusive powers of the Trustees in Georgia. ${ }^{4 \tau}$ The Trustees reconsidered the act, making two acts out of it-one to allow the importation of rum and the other to regulate it. These acts were also reported to

\footnotetext{
${ }^{10} \mathrm{C} . \mathrm{R} . \mathrm{V}: 415-416$.

${ }^{47}$ C. R. I: $40 \%$.
} 
the Board of 'Trade for its approval. To both the acts objections were raised: to the one, because it restricted too much the trade in rum and made no allowance for a British distillery; to the other, because its penalties were too severe for violations of the act. The Trustees had made changes once in the general act, as we have seen, and they refused to alter the acts further. The secretary of the Trust was ordered to request the return of the acts if they could not be approved as they were by the Board of Trade. ${ }^{48}$ Nothing seems to have been done at once, but after the lapse of nearly a year the Trustees were again informed that the objections had not been removed, ${ }^{49}$ and so far as the records are available, there is no indication that any agreement was ever reached in the matter. The Trustees merely allowed the government in Georgia to wink at the violation of the rum act in preference to making further attempts to legislate on the subject.

It must not be understood, however, that there were no peaceful and cordial relations between the Trustees and the Board of Trade. There was much routine connection between them which made no noise and so left no echoes, but the general relations could not be harmonious on account of the opposing viewpoints of the two bodies. The Trustees were probably unselfish to a very considerable degree in thinking it for the best interests of Georgia that they retain very full control of the provine, though reviewing this policy in the light of its results we can see that it hindered the development and trade of the colony. The Lords Commissioners for Trade and Plantations, having steadily in view the development and extension of English commerce and trade and

${ }^{48}$ C. R. I : 453-454.

${ }^{40}$ Ibid., 465. 
receiving the regular reports of the progress in Georgia ${ }^{50}$ which frequently failed to show much real growth or progress, could not look with favor on the policy of the Trustees. The latter were idealists; the Board of Trade looked for practical results. That the Board was not hostile to the colony itself appears when the 'Trustees had agreed to surrender their charter. The report of the Board of Trade on that occasion was very full and favorable to Georgia, and the presiding officer of the Lords Commissioners was known to be a firm friend of the colony. ${ }^{51}$ The question might be raised as to how much they were influenced in their report by the fact that after the surrender of the Trust they would themselves have the direction of the affairs of the colony, but it is hardly necessary to discuss the matter. The Board of Trade had always shown itself sufficiently friendly to the new colony itself, and any hostility that it may have shown was directed toward the methods followed by the Trustees in carrying on the work of settlement and development.

It was not with the Board of 'Trade alone that the Trustees disagreed in trying to maintain their complete control over Georgia; they also had misunderstandings with the Commissioners of the Customs and asserted their rights to the Lords Commissioners for executing the office of Lord High Admiral. The dispute with the customs officials was in regard to the appointment of a naval officer in Georgia. The Trustees appointed such an officer early in their administration, relying on the clause in the charter which gave them the gencral power of appointing officers. There was no difficulty in the matter until the colonists who were clearing their land of some fine timber wished to ship some

${ }^{50}$ C. R. Y : 455.

${ }^{51}$ B. T., Ga., XI: Martyn to Pres. and Assts., Jan. 23, 1752. 
of it to England for masts. 'There was a considerable bounty offered for such timber, and that alone made the shipments profitable, but the customs officers would not grant the bounty to Georgians on the ground that there was no regularly appointed naval officer in the province, claiming the right to nominate and appoint all such officials. 'The 'Trustees were not disposed to yield the point, but they were at a disadvantage in the affair and so they proposed to compromise by allowing their appointees to receive instructions from the Commissioner's of the Customs. 'This seemed to be satisfactory to some individual commissioners, but no progress was made in the matter. In 1739 efforts were again made by the 'Trustees to settle the point, but apparently it continued in dispute all through the proprietary period. 52

It was in 1748 that the Trustees asserted their powers of government to the Admiralty Board. 'They had received information that the Lords of Admiralty had appointed one Mark Care as Judge of the Court of Admiralty in Georgia. They wrote to the Admiralty Board that such action had been taken without their knowledge or consent, and they wished it to be understood that in them alone is the government of Georgia vested. However, in this particular appointment they were willing to agree, since they approved the ehoice that had been made. ${ }^{53}$ 'The boards of both the Customs and the Admiralty were right in law and in practice, and it is surprising that the Trustees did not know it.

While there is something of interest in the relations of the 'Trustees to the various exceutive offices noted above, there is not so much of importance in them so far as the actual life of the colony was concerned as in the relations of the 'Trust to the Chancellor of the Exchequer and to Parlia-

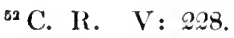

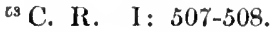


ment. Accordingly, these must be treated in some detail. Since the relations to the Chancellor and to Parliament were so closely connected, they will be treated together. Parliament had nothing to do with the founding of the corporation to settle Georgia ; it was an executive act of the King in council. Since Sir Robert Walpole was so large a factor in the administration at the time the charter was granted, his attitude toward the enterprise is of some importance. As a rule careless about colonial affairs, he may have thought the proposed settlement a matter of small importance, and he seems to have left it entirely to the Board of Trade and to the law officers of the Crown. ${ }^{54}$ Even if he did not look on the enterprise as an affair of small consequence, an experiment that could do no harm, it would be in keeping with his general attitude toward colonics in America. The Indians had been causing trouble on the Carolina frontier, and the proposed barrier colony might remove that source of irritation to the national government without any expense, since it was thought that charitable gifts would maintain Georgia without assistance from the English government. There was no immediate prospect that Georgia would be a source of trouble with Spain, and therefore, as the easiest and cheapest way of managing colonial affairs, it is not surprising that Walpole put no obstacle in the way of the settlement.

During the first year as it became evident that the contributions of charity would not be sufficient to cover even half of the expenses in Georgia, a petition was filed by the Trustees that Parliament would furnish a supply for the project. The petition set forth the three-fold object of the colony and asked that aid be granted for its further establishment and security. According to the usual form, ${ }^{s}$ C. R. V: 100. 
it was Walpole's duty as Chancellor of the Exchequer to declare the King's consent before such a petition could be presented to the House of Commons, ${ }^{55}$ and there is no evidence that he raised any objection to the grant of $\$ 10,000$ made to the 'Trust by Parliament. 'The next year no petition was presented to Parliament on the subject, but the King by his royal sign manual granted the sum of 23,161 for the furtherance of the colony. ${ }^{56}$ As Chancellor of the Exchequer, Sir Robert Walpole would no doubt have had an opportunity to oppose and very likely defeat such a gift, if he had been actively opposed to the colony, as it was later thought that he was.

During the next three year's the Trustees through peti-

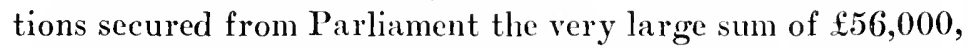
and there are no indications that there was any trouble in securing the grants. The Trustees were able to convince Parliament that the Spanish were threatening Georgia and South Carolina, and the large financial assistance was given principally for the purpose of defence. Finally, as we have seen, the government took over the entire defence of Georgia, relieving the 'Trustees of that responsibility and giving them concern with only the civil affairs of the province.

After this change the Trustees realized that it would be more difficult to obtain Parliamentary grants, and they very much desired to have the money they needed put into the yearly estimate, so that they would not have to petition for it year by year. Walpole seemed at first to favor them in the matter, encouraging them to hope that such an arrangement would be made, but in spite of his assurance both to Oglethorpe and to a committec of the Trustees, he continued to require that they petition as before, though he ${ }^{s 5}$ C. R. V: $: 281$.

${ }^{8}$ C. R. III : 71, 75. 
allowed their request for the $\$ 8,000$ sought. The same year he was planning to send a regiment under Oglethorpe to Georgia but the Spanish minister objected to the action so strongly that Walpole almost reversed his decision, and it was only after very persevering work of the Trustees that he finally agreed for Oglethorpe to proceed with the raising of the regiment. ${ }^{5 \tau}$

In 1739 it was again the purpose of the Trustees to ask for $£ 8,000$, and a committee was sent to the Lord Chancellor to remind him of his promise to put the sum into the estimate. He was willing to grant the money but he still refused to put it into the estimate. He explained to the members of the Trust that Spain and Great Britain were to settle by conmissioners the boundary of Florida and Georgia; and, while it was eminently proper to support the colony as long as it was in dispute, it was not proper to support the province in the estimate so long as it was at all disputed. In reality, however, Walpole thought that there was no place in the estimate for Georgia expenses, and he would seem to be right on the matter. 'The estimate generally covered only military expenditures of various kinds, and the civil support of Georgia could scarcely be reckoned as military. ${ }^{58}$

As a matter of fact, it seemed in 1739 as if Walpole would not be very averse to giving up Georgia to Spain in case this course would further the proposed convention with that country, and this indifference on the part of the Chancellor gave the friends of Georgia no little alarm. It did not reassure the Trustees when Walpole requested them to undertake a defence of the English right to Georgia. They realized that they were unskilled in such matters, and

${ }^{67} \mathrm{C}, \mathrm{R}, \mathrm{V}: 34$.

${ }^{5 s}$ Ibid., 88-89. 
they felt that he was giving them a burden in which they might fail, and in which their failure would be an excuse for giving up the province. Consequently they determined not to try to defend the British title, asserting that the King's grant was sufficient for them and that any further defence ought to belong to the law officers of the Crown. ${ }^{59}$ At the same time, affairs in Georgia became so bad that the Trustees found that the $£ 8,000$ which they had planned to ask for the year would not be sufficient for their needs and so they determined to press for $\mathfrak{2} 20,000$. Since Walpole was looking less favorably than before on the colony, it was determined to sound the attitude of the minority or the anti-ministerial party in the House of Commons. The latter was not hostile to Georgia and was willing to support the Trustees in their petition for money, if they would actively oppose Walpole in his scheme to give up the colony, as the minority asserted he was proposing to do. ${ }^{60}$ The support of Georgia was not, nor had it ever been, a distinctly political issue, and it was the policy of the 'Trustees to keep it out of politics so far as it might be practicable.

It was a difficult feat to steer clear of political entanglements. Walpole professed to be the patron and friend of Georgia and yet the Trustees were afraid to commit themselves to him. As a consequence he accused them of hostility to him. On the contrary, the minority were threatening to refuse further support unless the 'Trustees would join them tete baisse against the Ministry. Since they were courted and menaced by both sides, the Trustees thought a neutral position would be most dignified and effective, especially as the vote on the convention Walpole had arranged with Spain was likely to be very close in the House of

${ }^{69}$ C. R. V: 100-101, 109.

${ }^{\infty}$ Ibid., 104. 
Commons. ${ }^{61}$

This neutral position was almost impossible to maintain. It was deemed necessary by the Trustees that they consult Walpole about the proper time to petition Parliament for the money they required, and they felt, too, that his support was vital in getting the grant passed in the House of Commons. It was a problem with them how they might secure his aid without having to commit themselves to him in other matters. At length they determined to move in both houses a petition that Georgia might be fully protected by Parliament and might not be affected by the proposed convention with Spain. ${ }^{62}$

When the debate on the convention itself came up in the House of Conmons, Walpole was very anxious lest he might fail in the plan, and so he made strong efforts to secure the united support of all the 'Trustees who were members of Parliament. For a time it looked as if he would lose their votes, since many of them feared greatly that the convention would be dangerous to the colony in spite of the petition for protection that had been moved in Parliament. However, Walpole made some concessions to them in the matter of verbiage so as to remove their fears, and so he secured the support of most of the Trustees, passing his measure by a vote of 260 to 232 ; with the Trustees in opposition he could not have succeeded. The minority was much outraged that the Trustees should thus seem to be the mere tools of the majority, and some of the minority members of the Common Council went so far as to withdraw from membership in that body. ${ }^{63}$ Whether or not the Trustees truckled to Sir Robert Walpole to obtain their money, they

${ }^{61} \mathrm{C} . \mathrm{R} . \quad \mathrm{V}: 11$ ?-113.

${ }^{62}$ Ibid., 125-1@6.

${ }^{63}$ Ibid., 131-132. 


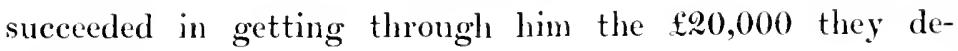
sired. ${ }^{64}$

In 1740 there was a stronger desire on the part of many of the 'Trustees than even in the preceding year to break away from dependence on Walpole. Money was no longer coming in from charitably disposed people and the only source of supply was that of grants by Parliament, so that it was essential to secure action in the House of Parliament. Hitherto this had seemed possible only with the cooperation of the Chancellor, but his waning majorities showed that he was becoming weaker in his hold on the government, and it was thought best not to be too closely identified with him. Besides, a sense of dependence was so distasteful to many of the 'Trustees that they had ceased to come to the meetings of the 'Trust. In order to put Georgia afiairs on a firmer basis both at that time and for the future, it was thought wise to take the sense of Parliament in regard to the province, securing if possible a Parliamentary inquiry and investigation. The 'Trustees thought that if evidence of the worth of the colony could be produced and a favorable resolution could be passed it would no longer be necessary to proceed by petition, but a sufficient annual support would be granted on motion. This would be a much more dignified method than that hitherto followed. This plan would mean a breaking away from dependence on the ministry, but it would regain the good will of the minority, and it would not be hostile to Walpole. His allies among the 'Trustees, however, urged that dropping him would really result in his dropping the Trust, and his power was well known. Should the appeal to Parliament fail, resort to petition would then be the only resource, and for this the King's consent could be obtained

${ }^{8 *}$ C. R. V: 147 . 
by Walpole alone. ${ }^{65}$ So dangerous did it seem to run the risk of losing lis favor that the Trustees finally determined to cling to their former policy of seeking the aid of the Lord Chancellor and of proceeding by petition, but they attached to the petition an offer to produce evidence of the worth of Georgia, if the House of Commons should choose to hear it. They hoped in this way to stir up an inquiry, but Sir Robert Walpole was no friend of Parliamentary inquiries in general, as they exposed many neglects of the ministry, and he opposed this one in particular, since it would likely remove the province from his control. He was successful in resisting the inquiry, but he granted the $£ £, 000$ the Trustees were asking for that year. ${ }^{66}$

By $17+1$ all hope of proceeding by any other method than that of petition had failed, but there was an earnest desire on the part of the Trustecs to lave the House of Commons institute an inquiry into the management of Georgia. They had prepared a formal account of the progress made by the colony sinee its establishment and they had distributed it widely among the membership of Parliament. It aroused sufficient interest in Georgia to make it easy for the proprietors to get an appropriation of $₫ 10,000$, but the effort to have a formal hearing again failed. ${ }^{67}$

The Trustees were sufficiently associated with the party of Walpole and his administration either in reality or in the opinion of the House of Commons, to suffer when he lost power and when a new ministry was formed. In 1742 the friends of Georgia followed the same tactics as in former years, sceking the aid of the Earl of Wilmington, the nominal head of the ministry, and of Mr. Sandys, the Chancellor of

\footnotetext{
${ }^{65}$ C. R. V: $980-281$.

${ }^{60}$ Ibid., 297-302.

${ }^{\theta}$ I bid., 445-446, 491.
} 
the Exchequer. 'The latter promised his support to the extent of securing the King's consent that the 'Trustees make their petition to the House of Commons, but the Earl of Wilmington was not very cordial. When the petition was moved in the House of Commons, the customary motion to refer it to the Committee of Supply was made, when, to the utmost astonishment of the 'Trustees, the motion was defeated and the Trust was left almost helpless. This was a great surprise and shoek to the supporters of Georgia. They made several attempts to secure the much needed money through a motion in the Committee of Supply itself, but for this the support of the ministry was needed and the latter met the requests of the 'Trustees with a genteel but firm refusal. A petition to the King himself net with no better results. ${ }^{68}$

While these disappointments were being suffered by the Trustees, further vexations were begun for them by Thomas Stephens, who had come to England claining to represent the people of Georgia. As the agent of the inhabitants of the province, he had on Mareh 30, 1742, presented a petition to the Privy Council complaining against the oppressions of the Trustees and asking for relief. This petition was referred to the committee of the council for plantation affairs and a copy of it was sent by the committee to the Trust with the desire that an answer might be returned as speedily as possible by the Trustees. This answer was filed on May 3,1742 , but before a hearing could be held by the Council the matter had been taken up by the House of Commons. ${ }^{69}$ On April 30 a petition was presented in the House for Thomas Stephens, but in the name of the inhabitants of Georgia, and it was moved that the petition be referred to ${ }^{\text {es }}$ C. R. V: 610-619. Ibid., 632 . 
a private committee. The friends of the Trustees objected to this disposition of the matter, because they feared that a committee might be selected that would be hostile to the colony and so they pressed for a hearing before the whole House and this was finally secured by them. The petition and answer that had been filed with the Privy Council were laid before the House and it was agreed that both sides should be allowed to introduce evidence and might be heard by counsel. ${ }^{70}$

Three solemn hearings at the bar of the whole House of Commons were held on the allegations of the petition and the defence of the Trustees was then presented. After hearing the counsel for both sides and debating the subject among themselves, the members of the House as a committee adopted six resolutions to embody their findings in the case. They approved entirely the usefulness of Georgia; they asserted that it ought to be supported and preserved, and they condemned the petition of Stephens as containing false, scandalous and malicious charges, but they reported in favor of changing one or two of the regulations of the Trustees. ${ }^{71}$ When these resolutions were presented as the report of the committee, the Home adopted them without change on June 29 ; and Thomas Stephens on the next day was made to kneel in the House of Commons and was reprimanded by the Speaker for his part in trying to asperse the characters of the Trustees. ${ }^{2}$

Since the hearing before the House of Commons, which had been so long sought by the Trustees had been held and had resulted so favorably to the colony, it was thought that there would be little difficulty in getting passed an address

${ }^{\text {70 C. R. V V }}$ 616-618.

i1 Ibill., 635-636.

"2 Ibid., 610-641. 


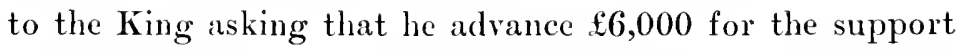
of the province, to be repaid the next year. 'The Trustees thought that in this manner they might retrieve their defeat in the spring when they tried in vain to secure money by any means then available. To earry out their plans, a motion was made on July 6, $1 \%+2$, that an address be sent to the King in favor of the province and it was hotly debated. So much opposition developed in the House that in spite of the resolutions adopted a week before for the support of the province the motion for the address had to be withdrawn to prevent its defeat. This left the Trustees without support for the year and there was much diseouragement among them because they obtained a justification from the charges of Stephens with so much difliculty and were unable to reap any financial fruitage from their justification. ${ }^{\mathbf{7 3}}$

This defeat was the climax of the relations between the Trust and Parliament during the first decade of Georgia's existence. 'The second decade was less eventful. There was little trouble in getting by a large majority the sum of $\mathfrak{1 1 2 , 0 0 0}$ in Mareh, 1743. In this case the opposition consisted almost entirely of Tories, ${ }^{\top 4}$ who had apparently gotten alienated from the Trustees when the latter roted with Walpole for the convention with Spain in 1739, and who had never become reconciled to the 'Trust as had the other elements of the opposition of 1739 .

The money granted in $1 \%+3$ was so economically expended that no petition for a supply was necessary in 1744 , the first time in the history of the colony that such was the case, and it was not until December, 17+5, that Parliament was again requested to furnish financial aid to Georgia. In the petition on this oceasion the resolutions of $1 \%+2$ in favor

${ }^{73}$ C. R. V: 612-614.

"I Itid., 68?. 
of the province were cited and it was successful; but it was more than a year afterwards that the money was received and on account of the war the amount allowed was only $\mathfrak{f} 4,000.7^{75}$

During the years $1746-1748$, the exigeneies of war made it so unlikely that money would be granted that the Trustees, though in sore need, did not petition for it. In January, 1749, they determined to make an effort to secure relief and the old method of appeal to the Chancellor of the Exchequer was adopted. Toward the close of 1744, the Wilmington-Carteret ministry had been overthrown and since that time the Pelhans had been in charge of the government. Both of them were borough-mongers of the type of Walpole and neither cared much for the colony, but the Trustees agreed to make a personal appeal to Henry Pelham. His aid was secured and a petition to Parliament was suceessful to the extent of about $55,000 .^{76}$ The next ycar a similar appeal was suceessful in securing a smaller sum. By this means the colony was kept going, but there was a constant handicap due to the lack of money. In 1751 the petition of the Trustees was defeated in the Committee of Supply of the House of Commons and the Trust was helpless. ${ }^{i \tau}$ On April 25, 1751, the Common Council appointed a committee of twelve persons, eleven members of the Common Council and one Trustee who was not a member of the Council, to adjust with the administration the proper means for supporting and settling the colony in the future and to take from time to time all such measures as they might find necessary for the well being of the province. ${ }^{\text {is }}$

${ }^{75}$ B. T., Ga., X: Verelst to Stephens, March 1, 1746.

${ }^{78}$ C. R. I: 536.

"B. 'T., Ga., XI: Martyn to Vice-Pres. and Assts., Apr. 27, 1751.

${ }^{74}$ C. R. II: 506. 
On May 6, 1751, this committee drew up a memorial to the King setting forth the progress of the colony since its founding, its present condition and the inability of the Trustees to maintain its civil government and to keep up the other necessary services. It prayed for such aid as might be necessary for the fulfilment of the 'Trust. 'The memorial was presented to the Privy Council and was referred by the Council to the Board of Trade and to the C'ommissioners of the Treasury. On December 19 the Privy C'ouncil net to consider the memorial and the reports thereon by the bodies to whom it lad been referred. After considerable consultation and after the presentation of some requests by the committee of the Trustees in behalf of the inhabitants of Georgia, the committee definitely agreed to surrender the charter of the Trust to the Crown without limitations or conditions. The Privy Council had informed the 'Trustees that this was a sine qua non condition on which any more money could be recommended for Georgia." In view of the proposed surrender of the charter, the Trustees were suecessful in appealing to the House of Commons for a sufficient sum of money to defray the remaining expenses of the 'Trust.

The law officers of the Crown were consulted as to the manner in which the charter should be surrendered and they advised that the Trustees should exceute a deed under the direction of the Common Council of the corporation giving up all rights which the charter had conferred and also yielding to the Crown the one-eighth interest in the land of the provinee which the corporation had secured from Lord Carteret. Accordingly, on June 23, 1752, at a meeting of only four 'Trustees, the indenture of surrender was duly excented and exchanged for a counterpart under the Great Seal signifying the acceptance by the king of the deed so exeeuted ${ }^{79}$ C. R. II : 513-515. 
by the Trust. 'This ended the corporate existence of "The Trustees for Establishing the Colony of Georgia in America" after a life of twenty years and fourteen days. ${ }^{80}$

It is not so surprising that the English government refused to continue the support of Georgia under the Trustees as it is that for so long a time it bore this burden. It had never been thought a function of the government to render financial aid to colonizing enterprises. From the beginning it had been considered proper that the government should grant land to those wishing to make a colony and to furnish protection for it and to give to its people the rights held in common by Finglishmen, but it had also been thought unwise for it to finance any colony. On what ground, then, did the Trustees appeal to Parliament for support and why were they successful in their applications? Of course the objects which the founders had in view for Georgia appealed to the members of Parliament as worthy of encouragement; the relief of the poor, the extension of British trade and the development of manufactures, and the defence of British possessions were as strong motives as could influence Englishmen to action. It cannot well be doubted that the argument which secured the largest appropriations was based on the need of defence, but after the government had taken over that burden, leaving to the Trustees only the civil affairs, there were frequent and somewhat generous grants. Why should these grants be made to Georgia when other colonies did not receive them? The Georgia authorities were bold enough to ask and to press earnestly for the money and the precedent already begun of making yearly grants to the colony was of help now, even though no plea could be made on the ground of defence. Of more influence perhaps was the personnel of the 'Trustee Board. Consisting of ${ }^{50}$ C. R. I: $5 \% 8$. 
many of the most eminent men in England, and including a large number of members of Parliament, it could command in England more influence and prestige than any former colony. Parliament would not lightly refuse a petition earnestly pressed by such a body of men, and their influence was the greater because they were known to serve without pay and without there being any possible opportunity for personal gain. There can be little doubt that respect for the Trustees had more weight in moving the House of Commons than a realization of the advantage of Georgia and of the necessity for its support. We have noticed that the grants were generally made through the influence of the ministerial party; perhaps the motives prompting the Ministry to generosity were not so high even as respect for the members of the 'Trust. Walpole and the Pelhams were notorious borough-mongers and it is not surprising that they would readily make grants to hold the good will of the large number of votes commanded by the Trustees in Parliament. 'The latter made no offer of support in return for financial aid, but it was inevitable that they should be closely affiliated with the faction that alone made it possible for them to carry on the purposes of their charter. 


\section{CHAFTER $V$}

THE EXECUTIVE IN GEORGIA

7 THERE were three varieties of colonial government in

1 the British settlenents of Ancrica. Viewed from Westminster, these differed widely in their nature. 'The royal province was under the direct control of the king, from whom all the executive authority was derived and to whom all the officials of the province were directly responsible. In theory at least, this type of government was easily controlled by the lome government, and it was the form to which the organs of imperial control in England desired to bring all the British plantations. 'The proprietary province differed from the one just mentioned in the important particular that the govermment of the province emanated from a lord proprietor or from a board of proprictors and was not directly responsible to the King. 'The extent of imperial control over this form of goverument depended on the terms of the charter granted to the proprietor, but it was in any case limited. The corporate colony was under the control of a corporation created by the King in council, and the government and corporation were practically merged into one. 'This form of government was also very difficult to reach and to control by the administration in England. In spite of these differences, which were so painfully manifest to the home government at Westminster, the actual results in all types of colonies were strikingly alike. In all of those existing when Georgia was established, there were 
a governor and comneil with various other executive officials, besides the legislative and judicial machinery and organization; and while in some details the powers and functions of these officers differed in the various colonies, there seemed to be a general agreement as to what was neeessary and best for the proper management of any British plantation.

Although the Trustees for Georgia received for twentyone years full powers of govermment, the Board of 'Trade and the Privy Council assumed that the new province would have in general the same executive control that had been established in the other colonies of whatever type. Accordingly the charter provided that every governor of Georgia must be approved by the king and must duly qualify himself for office in the mamner required in other Aneriean plantations. $^{1}$ In order to thus qualify, it was necessary that the governor elect be approved by the king, that he take the usual oaths required of British officials, that he give security to observe all acts of Parliament relating to trade and navigation, and that he also give security to observe and obey any instructions sent by the king or any other authority in England pursuant to said acts. 'The governor of the new province was the only appointere of the Trustees who was required to conform to these rules, which were merely those which the British government was trying to require of the chief executive in every type of colony.

The records of the carly years of the Trust contain no hint as to the reason why the usual organs of government were not adopted; but there are several circumstances that may partially explain the matter. 'The Trustees were at first much nore interested in the charitable feature of their work than in any other; and, not being experts in framing governments, they simply neglected to give the executive ${ }^{1}$ C. R. I : 24. 
administration of the province much care. Moreover, the settlement of only one town was contemplated in the beginning and it was no doubt thought unnecessary to establish for it a fully organized provincial system of government. The additional fact that Oglethorpe proposed to accompany the early settlers made the Trustees feel easy, since they could instruet him in detail about matters that could be decided in England and they could trust his judgment in affairs that could be settled only in America. Using him as an attorney, they could in reality retain practically all authority in themselves, and it is beyond question that this was an end eagerly sought by the Trustees. It is evident that by 1739 the members of the Trust were unwilling to adopt the usual organs of govermment because of a dread of supervision by the Board of Trade, which body they regarded as hostile to them, ${ }^{2}$ and it may be that this jealousy of the Board may have had weight in their early determination not to appoint a governor, though the evidence is lacking that the Trustees felt toward the Board of Trade in 1732 as in 1739.

Whatever the causes that influenced the Trustees, they chose to follow a plan of internal government for Georgia that was entirely unlike that of any other British colony. A municipal administration was chosen as a model rather than that of a province. Shortly before the first settlers left England for their new homes, the Common Council appointed the following officials: three bailiffs, a recorder, two constables, two tithingmen, and eight conservators of the peace. $^{3}$ Several important points are to be noticed in regarl to these officers. There was no chief executive corresponding to a modern mayor. The bailiffs were designated

\footnotetext{
${ }^{2}$ C. R. V: $115-416$.

${ }^{3}$ C. R. II: 11 .
} 
as "first," "second," and "third"; but no powers were granted to the "first bailiff" that could not be exercised by either of the others. No salaries of any sort were established for any of the offices and so no one of them was more dignified in that particular than any other. 'There was no tendency to hold a man to one ofince only, but any one might hold several positions under the Trust at the same time.

'The officials thus named on November 8, 1739, composed the entire government of the provinee. 'The powers expressly granted to them were almost entirely judicial, but they were also expected to put into execution the various laws and regulations that might be established by the 'Trustees. It is a curious fact that no explicit instructions should have been given to these magistrates. The botanist of Georgia received formal instructions, but they seem to have been thought unnecessary for the magistrates of Savamah, to the limits of which town the authority of all the officers named was restricted. 'The officials consisted largely of destitute persons for whose relief the colony was projected, and their experience in public aifairs was limited, so that they surely needed advice and directions. No definite statement of the fact is anywhere made, but it is reasonable to suppose that they were to get from Oglethorpe whatever information might be needful while they were learning the duties of their respective offices.

We have already noted that the powers directly granted to Oglethorpe were very meager indeed with which to operate a colony three thousand miles from the source of authority and power; and their insufficiency was probably the cause for the assumption of authority by Oglethorpe and others to the general dissatisfaction in many cases of both the colonists and the Trustees. There was a tendency to give

"B. T., Ga., XII: 14-21. 
specific and individual directions rather than general authority. This may be illustrated in the matter of administering oaths. Oglethorpe was authorized to give the oaths to the officials who were first appointed by the Common Council. When new constables were chosen for the increasing number of people in 1733, the first bailiff was directed to administer oaths to them; but in October of the following year the recorder is authorized to perform this service for certain new officials. ${ }^{5}$

When Oglethorpe was preparing to return to England in 1734, powers were granted to James St. Julian of South Carolina and to Francis Scott of Georgia to set out and distribute lands and to grant licenses for leaving Georgia. These were the principal functions that had been assigned to Oglethorpe; but a little later a general commission was issued to the same gentlemen to execute all powers and appointments made to Oglethorpe which might remain unexecuted by him. ${ }^{6}$ If Oglethorpe were governor de facto or if he were expected to be the principal executive in Georgia, these men, one a South Carolinian, had full right to succeed him in his work; but Oglethorpe's influence and power in the province rested on his known interest in the undertaking, rather than on any commission or authority, and of course it was impossible for others to take his place.

As the colony grew, several out-stations or villages were established. In order that they might be under some form of government, the 'Trustees arranged to extend the precincts of Savannah so as to include the new settlements, thus stretching the municipal plan of govermment on which they had started into something resembling provincial control. The bailiffs of Savannalı were to exercise authority in the

'B. 'T., Ga., XII : 90, 156.

${ }^{\circ}$ C. R. II : 43-45. 
new settlements, but additional constables and tithingmen were chosen. ${ }^{7}$

During the first year there developed an executive office insignificant in title but destined to play an important part in the history of the colony. It seems not to have been formally authorized by the 'r'ustees and no regular commission was sent to the holder of it, though private instructions were oceasionally sent by letter.s It was ealled for by the exigeneies of the situation, and it seems to have been filled by Oglethorpe's appointment. 'This office was that of storekeeper for the 'Trust. At first thought, it would seem a trifling matter to deal out supplies to the inhabitants of the colony, but there were several circumstanees that gave quite a different aspect to the matter. Practically all the settlers of the colony were at first dependent on the 'l'rust for support, and this was given in the shape of supplies from the general store. 'The few independent inbabitants had to buy their goods from the Trust store. Thus it came to pass that the storekeeper came into direct and frequent contact with every inhabitant of the province. Moreover, the storekeeper had either by grant or assumption large diseretionary powers as to both the quantity and quality of goods to be furnished the charity settlers and as to the prices to be charged those who were self-supporting. In this way he was able to exereise a large control over the comfort and prosperity of the people of Georgia. Again, under the direction of Oglethorpe the storekeeper was allowed to issue drafts or bills on the 'Trustees for the supplies purchased for the store and also for the general expenses of the province." Here also there was much room for discre-

${ }^{7}$ C. R. II : 43.

${ }^{8}$ 13. 'I'., Ga., V'II : Martyn to Causton, Dee. 13, 173t, et seq.

${ }^{8}$ C. R. II : 64 . 
tionary powers with a corresponding danger of abuse. A correct understanding of the scope and influence of the office of storekceper will explain many of the later troubles of the province.

In the spring of $173 \mathrm{t}$ a settlement of Protestants from the Duchy of Salzburgh in Germany was established at Ebenezer in Georgia. It was soon a town of about one hundred and fifty people; but it is interesting to note that no provision whatever wats made by the Trustees for any civil officials in the community. It was not comected with nor made subject to the town of Savamnal. Under the spiritual guidance of its pastor, it was to run itself without executive, judicial or legislative control except what might come directly from the Trustees themselves. While Ebenezer was the largest settlement thus left without provision as to govermment, it was by no means the only one so situated. At Abercorn, Joseph's Town, Skidoway Island, Thunderbolt, and numerous other points, there were groups of families or little villiages for whose government or control the Trustees hand not established any oificials or authority in Georgia. ${ }^{10}$ It may be prestmed that the government of Savamah would assume jurisdiction over these outlying settlements. This had been specifically provided in the case of the little village of Thorpe, ${ }^{11}$ and it could be only by inference that it would be true of the other communities; and it would require some stretch of the imagination for the "town" of Savannah to include all the territory within a range of twenty or thirty miles. The truth seems to be, as already intinated, that the Trustees were not yet concerned about a govermment within the province.

When in 1735 preparations were made to settle the south${ }^{10}$ Jones-Hist. of Ga. I: 147-149.

${ }^{11} \mathrm{C} . \mathrm{R}$. II : 43. 
ern part of the province, the Trustees adopted the same program which had been used in the settlement of Savamnal, appointing bailiffs, a recorder, constables and tithingmen just as in the first instance. ${ }^{12}$ 'The northern and southern parts of Georgia had no orginic governmental connection. There were no common officials or courts to bind them together. 'They were in effect two separate municipalities, interested in each other as neighbors, their closest tic of union being a government three thousand miles away. With reference to the new town of Frederica, Oglethorpe was given meager powers, similar to those which he had been commissioned to exercise at Savannah. ${ }^{1: 3}$ Just as the Salzburghers had made a large settlement in the northern part of the province without eivil officers or govermment, so on the southern boundary the Scotch established a colony without bailiff, recorder, constable, or other official, so far as we have any record. Presumably their settlements of Darien were to be under the general jurisdiction of Frederica, but there seems to have been no law or order to that eifect.

On July 16, 1735, the first financial remuneration to the officials at Savannal was given. All of them had been granted certain privileges as to getting supplies at the store and having servants, and these things were of value; but no money was paid until after wearly three years of service. Even then it was granted as a sort of gratuity rather than a fixed or permanent salary for any official. 'The sums of money granted to the officials were quite modest. The storekeeper was recognized to be the most important official in the colony, for his salary was four times that given to the holder of any other office. Me received forty pounds sterling, while the second and third bailiffs, the recorder and ${ }^{12}$ C. R. II : 125 .

${ }^{13}$ B. T., Ga., XII : 218, 247. 
the two constables received ten pounds each. ${ }^{14}$ The first bailiff had been remored and no one had been appointed in his place; ${ }^{15}$ but the fact that no difference was made in the amounts paid the "second" bailiff and the "third" one or between the bailiffs and the other officers with general executive duties indicates that the Trustces were continuing the policy of not elevating any one to a superior executive position in Savannah or in the province.

Before 1735 no formal laws had been passed for the province, but in that year laws were enacted for prohibiting the importation of rum, for excluding the use of negrocs, and for regulating the trade with Indians. ${ }^{16}$ In order to carry them into effect more executive administration was necessary than had heretofore been cstablished. Instead of concentrating the authority that was needful in one person or in a small council, the Trustees established a large number of petty offices, distributing them among several different men. For instance, Ogiethorpe was made sole Commissioner for Licensing Indian Traders; but the money from this source was to be handled by a Treasurer of Indian Affairs; and, besides, there was to be a Secretary of Indian Airairs. ${ }^{17}$ The duties of none of these officer's were specified in the commissions, but the titles themsclves are sufficiently suggestive. The work connected with the Indian trade was very small and it occupied only a few weeks during the year, so it seems that the Trustees instituted a needless division of authority.

The policy of dividing executive functions was not confined to Indian affairs. It was followed in much the same

${ }^{14} \mathrm{C} . \mathrm{R}, \mathrm{II}: \mathrm{I12}$.

${ }^{15}$ B. T., Gi., XII : 225.

1" C. R. I: 31 et seq.

1; B. T., Ga., XII : 236-237. 
way in enforcing the rum act. A special officer was appointed to stave and empty all brandy, spirits and strong waters brought into the province contrary to the act. 'The bailiff's and recorder were appointed a commission to grant licenses for retailing wine, beer and ale which were to be allowed by the law. In addition a general naval officer was appointed by the Common Council upon whom also devolved part of the duty of exccuting the act. ${ }^{18}$

For enforcing the act against the importation or use of negroes in Georgia, the constables of the province were especially commissioned. ${ }^{19}$

It would seem well that the Trustees enacted only the three laws already mentioned; for if they had passed as many as the ordinary province found necessary, and if they had appointed as many different persons to put each law into execution as they chose for the first three, the province would not have been able to furnish enough men for the offices that would have been created. One gain in effective administration was noticeable in the appointments made, even though authority was so widely diffused; the officers chosen were to exercise their powers throughout the whole colony, and so there was started a shadow of unity in government between the northern and southern parts of Georgia. 'This tendency toward a single government over all the colony was continued in two appointments of ninor consequence except as showing the general drift of the minds of the Trustees. A register was appointed to record all grants of land whether in southern or in northern portions of the province; ${ }^{20}$ and there was also chosen an inspector of the public gardens and nulberry plantations. ${ }^{21}$

\footnotetext{
${ }^{18}$ 13. 'T., Ga., XII: 239, $211,253$.

${ }^{10} \mathrm{C} . \mathrm{R} . \mathrm{II}: 124$.

${ }^{20}$ B. T., Ga., XII : 252.

${ }^{21}$ Ibid., 164.
} 
During the first four or five years of the colony's existence there had been appointed, as we have seen, some ten or more officials or commissions to do executive work in Georgia. In addition there were the regular bailiffs, recorders, constables and tithingmen, all of whom had duties that were to some degree executive. But there had been created no central authority to bind into one cohesive and effective whole these various appointments. We have seen that Oglethorpe may have been expected to exercise an authority around which the other offices would center, but it is more likely that the Trustees were simply allowing matters to drift. They had never authorized Oglethorpe to act for them on any extensive scale, but if they had expected it, it would have been impossible. He was out of the province a great deal, and after 1735 his almost constant residence at Frederica made it impossible for him to supervise work at Savannah, where most of the executive officials were located. In the absence of an executive head for the province, each official was expected to make reports of his work directly to the Trustees, and if he did not understand instructions or if he met with unusual circumstances not covered by any instructions, he was to write to the Trustees for guidance. As a matter of fact, very few letters or reports were ever sent by the various officers to the Trust; they were in many cases men who were not accustomed to correspondence and they simply neglected to make reports. The Trustees were much concerned at their failure to hear from their employees. On several occasions they sent earnest requests to Oglethorpe that he stir up the officials to their duty, and like requests were sent to the storekeeper when Oglethorpe was away. ${ }^{2}$

${ }^{22}$ So many letters to this effect were sent that only a few typical examples can he cited. B. T., Ga., VIII: Martyn to Oglethorpe, March 
In order to remedy this very unsatisfactory state of affairs, on April 2\%, 173\%, the Trustees determined to send a person from England to represent them directly in the colony, a man whose sole business it would be to receive regular reports from all officers and to transmit these to the 'Trustees, to deliver instructions from the home office to the various employees in Georgia, and to observe and report all phases of progress or decay within the province. The new officer was to be called the "Secretary of the Trustees in Georgia." His appointment marks an epoch in the executive history of the colony; for to him were given the first detailed instructions ever issued by the Trustees, including both public and private directions, and he was to be the attorney of the Trust in Georgia in a much more general and yet more definite sense than Oglethorpe hatd ever been. According to the terms of the agreement between him and the T'rustees, he was to be paid fifty pounds in England before laving and he was to receive on demand in Georgia fifty ponnds per annum. In addition, he was to have free transportation to Georgia for himself and three others, he was to be supplied with ten servants and with abundance of tools, and his family and servants were to receive provisions from the store for a year. In return for these benefits, the secretary was to serve the Trust for six years and was to continue to do so at the end of that time should he remain longer in the province. ${ }^{23}$

24, 1731: The Trustes are quite anxions to seeure a correspondent who would send regular reports by eich ship concerning all details of the colony's progress. Ihid., Martyn to Causton, January 25, 1735: The hailiffs, recorder, and surveror are all at fanlt in not writing to the Trustees. 1bid., Terelst to Oglethorpe, November, 1736. The Trustees have heard nothing from the province since June, and affairs have become very eritical on account of the lack of news.

${ }^{23}$ B. 'T., Gia., XII : 312 et seq. 
Since to this secretary were issued the first real instructions from the Trustees as to the executive management of the colonial government, and since out of this office of secretary later developed the principal executive of Georgia, it will be worth while to examine with some care the rather tedious papers with which he was provided by the Trustees. The commission provided as usual that the secretary was to hold office until a successor had been named in his place. He was to obey all instructions from the Common Council of the Trustees. All magistrates and peace officers in Georgia must respect lim as the direct representative of the Trust in the colony: they were to assist him in every way possible and were to obey the instructions produced by him for the execution of his office. ${ }^{2+}$

The instructions to the secretary were classified and were very voluminous, a brief abstract only being given below. The secretary was expected to perform the following duties:

\section{AS TO NILITARY AFFAIRS}

1. To send an account to the Trustees of all able men from twenty to fifty-five years of age in every village or town of the province.

2. To send a complete account of all the forts in the colony, including details as to the garrisons, cannon, powder, muskets, swords, bayonets and other supplies, and to tell what might be needed to complete the equipment.

3. To make out a report of the storehouses in the forts and to specify what might be lacking in them, and also to report what supply of fresh water was available in each fort.

${ }^{24}$ B. 'T., Ga., XII : 322. 


\section{AS TO CIVIL CONCERNS}

1. To write of the behavior of the people toward their magistrates-their industry, sobriety and obedience to laws.

2. To report all negligence of the surveyor and to ascertain who could do that work.

3. To investigate the reasons given by people for not cultivating their land.

4. To report on the number of people in the towns or villages classified by nationality and by families.

5. To make a list of gentleman freeholders with the servants employed by them.

6. To tell how cultivation and enclosing of lands were progressing, mentioning those who were industrious and also those who were not.

7. To give an account of the progress in silk and in the planting of mulberry trees.

8. To report on the public gardens, telling how the vines were growing and whether there was any prospect of making wine in the colony.

9. 'To write whether coffee was being cultivated or not, and also what other berries, roots, drugs or bark might be useful.

10. To estimate whether the timber cut for building and traffic would leave enough for future fuel.

11. To report whether the timber on Trust lands was being preserved or not.

\section{AS TO RELIGIOUS CONCERNS}

1. To tell how the people, and especially the magistrates, attend services.

2. 'To write how the lands set aside for religious uses were cultivated. 
3. To recommend to magistrates the punishing of vice and immorality and the encouragement of reverence; and also to encourage the ministers.

4. 'To encourage magistrates to place the ehildren of the colony in sehool; to inspect the schools; and also to exhort parents to send their children to school.

5. To recommend to the magistrates that they do the same for the Indian children.

\section{AS TO GENERAL MATTERS}

1. To call regularly on the magistrates, reeorder, surveyors, public gardeners and the register for their aceounts and reports and to send these quarterly to the Trustecs.

2. To make suggestions to the Trustces as to what would be for the good of the colony.

3. To report all news and happenings of interest.

4. To see that the naval officers report to the Trustees all ships that come into Georgia ports and what cargoes they brought.

5. To write to Trustees at every opportunity.

6. To send duplicates of all letters by the next ship.

7. To keep a record of all letters sent or received by him, recording to whom they were given or from whom they were received.

These public instructions were to be exhibited to the magistrates or to the people, if thought desirable, to support the authority of the seeretary or to explain the many inquiries which he was compelled to make. In addition, private instructions were given to him; and these were not to be made publie. 'The main points in the private directions were:

1. 'To give confidential opinions as to the magistrates and 
other officials, especially as to their industry and their ability.

2. 'To tell how the stores were distributed.

3. 'T'o report fully whatever complaints the people made against their magistrates. ${ }^{25}$

The office of Secretary of the 'Trustees in Georgia, thus established, was to aid the executive power in England rather than to strengthen it in Georgia. Its chief function of giving information concerning every phase of colonial activity or inactivity would assist the Trustees in formulating and executing their designs; but it was of small consequence in the colony itself, since the secretary was invested with no real powers of government. As a mere observer and adviser, the principal influence he was likely to have on the officers of the colony was to stir up a feeling of resentment toward him as an officious meddler or spy of the home government. The governors sent out by the king or by proprietors were also expected to observe and report on much the same matters as were prescribed for the secretary; but that is the only resemblance between the leading executive officer of Georgia and that of the other British colonies.

After 1737 the Trustees still adhered to their policy of issuing special commissions to particular persons whenever any unusual executive work was to be done in preference to issuing general commissions that would cover any unforeseen work that might arise. For instance, when the accounts of the storekeeper seemed to be getting confused and he was suspected of fraud, Oglethorpe was directed to suspend him; ${ }^{26}$ and a committee of three was named to investigate matters, and these had to report not to Oglethorpe or any one else in the colony but directly to the Trustees, and if

${ }^{25}$ B. T., Ga., XII: 323.

${ }^{2 \pi} \mathrm{C} . \mathrm{R} . \mathrm{V}: 37$. 
doubtful questions arose proceedings would have to be delayed for months until queries could be sent to England and answers returned. ${ }^{27}$

It was not until $17+1$, after nine years of experiment, that the Trustces finally took steps looking to the establishment of a government in Georgia that would be anything more than a shadow of authority. The changes made were so important that it is necessary to review briefly the steps by which they were brought about. At a meeting of the corporation, on December 2\%, 1740, James Vernon commented at length on the state of the colony as to government. He showed that the magistrates thought it a duty, when instructions were sent them by the Trustees, to consult General Oglethorpe before executing the commands, and that frequently instructions were not executed at all. He deplored the difficulties encountered in getting at a knowledge of the true state of affairs in the colony, in consequence of which the Trustees were unable to refute the malicious stories and lies which were being circulated in England. As a remedy, he suggested that it might be necessary to invest some person in the province with power superior to that which any one had yet exereised in the colony, and he further suggested that such a person ought to be made distinctly independent of Oglethorpe. He thought that it might be wise to establish in each division of the province a president and a council. He argued that creating two presidents would be wiser than having only one, because the latter would be practically a governor and would have to conform to the regulations of the charter relative to the governors of the province. He stated that the Trustees might as well surrender the charter as to allow their appointees to take instructions from the Board of Trade as was the case with ${ }^{27}$ B. T., Ga., XII : 388. 
governors of other colonies, because the Board was hostile to the policies of the 'Trustees. Vernon did not make a motion embodying his suggestions, but he urged their consideration. 'The Trustees present were pleased with his proposals and asked that he prepare a definite plan to carry out his ideas. $2 \mathrm{~s}$

On January 12th following, the Common Council examined the general plan he proposed and appointed a committce to digest and prepare instructions for the officials to be selected. The committee was not restricted to the plan that had been presented by Vernon, but it was authorized to consider in every way the better regulating of the govermment of the province. 29 On January 20 and 23 the committee worked on the plan and finally agreed to follow very closely the suggestion of Vernon; ${ }^{30}$ but the report was not finally ratified in the Common Council until April 15, 17 4 . On that date it was agreed to divide the province of Georgia into two counties to be called the County of Savannah and the County of Frederica. The former included all the settlements on the Savannah and Ogeechee rivers and so much further to the southward as might be determined by an aceurate survey which was to be made. All the rest of the lands granted to the Trust would be included in the County of Federica." ${ }^{31}$ The government of each comnty was to be mder a president and four assistants. The new administration was not at all municipal; but in a way it merged into itself the existing town government of Savannah and was intended to merge that of Frederica also. This was brought about by having the bailiffs of the towns to act as assistants

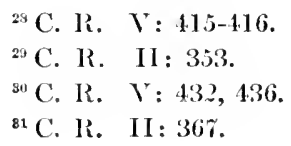


for the counties, while the recorder at cach place was to serve as clerk for the president and his board of assistants. The bailiffs and recorders acted just as before for the towns, their new duties being of a higher executive order than the ones before exercised and not interfering with them in theory at least. This uniting of offices in the person of one man is quite different from the policy pursued by the Trustees in 1735 .

On April 20, 1741, the Common Council adopted the instructions that had been prepared for the president and assistants of each county, and the new system was ready for operation. $^{32}$

The powers granted to the various officials and the instructions sent them were not materially changed during the remainder of the proprictary period; and they are of the utmost importance for a proper understanding of the executive management of the province. The commissions and instructions were the same for the officials of both counties; and so they may be treated as one. ${ }^{33}$ The president and assistants were to take the usual oaths. They were all removable at the pleasure of the Conmon Council and were to act under its directions. The president with two assistants formed a quorum to do business; and, if the president were necessarily absent, the first assistant might act with any other two of the board. When the president was absent, however, the actions of the assistants must be approved by him in all cases except that of appeals from courts below. ${ }^{3+}$

The powers granted to the new president were impressively meager, relating mostly to trivial matters of routine.

${ }^{22}$ C. R. II : 369-370.

${ }^{33}$ The government was never put into operation in the county of Frederica for reasons to be given later.

34 13. 'T., Ga., XIII: 6 et seq. 
With reference to his fellow officials, he was allowed some influence. He was authorized to send to the Trustees a list of five persons whom he thought suitable to be appointed assistants if vacancies in the board should occur; he would thus seem to have some part in naming future assistants, though the Common Council did not pledge itself to abide by his nominations. He had the authority to suspend an assistant who should stay away so long as three months without license from the president, and he conld fill the place of such an assistant temporarily until the Trustees could decide the matter. The president might also remove a clerk and appoint another in his place, who should hold the office until the pleasure of the Common Council might be learned.

As to military authority, he was to control entirely the boats belonging to the 'Trust. He was authorized to enforce guard duty and to inspect the Trust servants. It was also his duty to sce that the friendship of the Indians was maintained, though he was not empowered to take any definite measure to accomplish this end. He was assigned a hundred pounds at a time, with a limit of three hundred pounds for a year, for his sole expenditure without previously consulting the assistants, though he was required to render a strict account of how the sums of money were expended.

Finally, the president was to enforce the law against the use of negroes, and he was to prevent monopolies in the sale of useful commodities. ${ }^{35}$

'The truth is that the great majority of the instructions given to the president did not confer powers, but they rather specified duties to be performed, and such duties as required capacity for details more than great authority. He was directed to call a special court for the installation of the new ${ }^{35}$ B. 'T., Ga., XIII : 7-8. 
offices; he was to send an alphabetical list of the inhabitants of his county each year. He was to see that an aecurate map of the county be made as soon as possible. The president was also instructed to send in regular reports of the progress in the towns and plantations; and he was to keep a eomplete list of the arrivals and departures of ships with their passengers in either direction. He was to feel free to suggest any changes in government that would be advantageous for the eolony. ${ }^{36}$

The president was required to transmit to the Trustees copies of all proeeedings in which he was engaged. He was also direeted to reeord all orders sent to Georgia that passed through his hands. Births, deaths and marriages were to be reported regularly to the 'Trust; and marriage bans were to be regularly published by the president. It was his duty also to keep the Trustees informed as to all lands that were oceupied, but not registered; and was expeeted to see that the surveyor ran out speedily all land grants and that the proper reservations for the Trust were made. ${ }^{37}$

The executive board, consisting of the president and assistants acting together, had comparatively little power. It could license persons to retail liquors, and it must see to it that unlicensed houses must not be operated. It was to be an appellate eourt for cases arising in the town courts where the amount involved was twenty pounds or more. This is an interesting provision, since a majority of the court of appeals would eonsist of the three bailiffs who were the judges in the town court. The president and assistants were authorized to fix a table of moderate fees for eourt charges, to be approved by the Trustees. One of their most important functions was to issue the public money in pay-

\footnotetext{
${ }^{30}$ B. 'T., Ga., XIII: 9.

${ }^{87}$ Ibid., 12.
} 
ment of the colonial expenses; this must be done on the warrant of the president, concurred in by a majority of the assistants; but there was no authority in the colony which had any power to contract a debt for the province. The president, with the consent and advice of the assistants, could appoint and remove constables and tithingmen. This board had general charge of the Trust servants, and it would give them land and various houschold supplies when their terms as laborers expired. 'The board was also especially enjoined to derise the best possible means for converting the Indians to Christianity.:"s

As has been noticed, the county of Savannal was the only one to be organized muder the new form of government. Vernon had suggested that Oglethorpe be complimented with the office of president for the county of Frederiea; but for some reason this was not done, and as no suitable man for the position appeared the old form of government for the town of Frederica remained, and the same lack of govermment continued in the rest of the county. General Oglethorpe had been asked to recommend a proper person for president and also for the fourth assistant; ${ }^{39}$ but he was busy with preparations to neet the Spanish invasion, and there is no evidenee that he made suggestions. After a linpse of nearly two years, the board of 'Trustees reconmended to the Common Council that the two counties of Georgia be united under one govermment; ${ }^{40}$ and on June 10, 1743 , the Council adopted the suggestion and made the necessary arrangements for a single government in the colony to exereise authority over the whole province. It was ordered that the president of the county of Savimnah be the

3s B. 'T., (ial., XIII: 15.

${ }^{39}$ C. R. V' $V^{+} 494-495$.

40 Ibid., 690. 
president of all Georgia. The three bailiffs of Savannah with one additional man were made the assistants for the whole colony. The bailiffs of Frederica were to be only local magistrates; and the recorder was to correspond with the president and assistants in Savannah so that the commands and regulations of the colonial executives might be speedily transmitted to the southern part of the province. ${ }^{41}$ Private and public instructions were sent by the Common Council to the president and to the president and assistants combined; but these were identical with those sent to the officials of a single county, as previously outlined.

Thus after a period of eleven years and a day from the time the charter was granted, Georgia was united under an executive administration not very different from that which existed in the other British colonies of America. The chief executive bore the title of "president" instead of "governor," and a small board of assistants took the place of the generally more numerous council; but these were slight distinctions. More fundamental were the differences in the amount of power vested in the executive of Georgia from that of the other provinces, the former being notably weaker; but nevertheless the changes were a great advance over the other arrangements that had been tried by the Trustees. On May 23, 1745, on the reconmendation of the general corporation, the Common Council increased the number of assistants to five; ${ }^{42}$ and somewhat later a sixth one was added specially for the Salzburghers. ${ }^{43}$ The government, as thus organized and modified, continued to the end of the proprietary period and until the royal rule was established.

The salaries paid officials in Georgia were small, but they

${ }^{41}$ B. T., Ga., XIII : 49.

${ }^{42}$ Ibid., 76.

4s Ibid., 209. 
were paid in sterling money. 'The president of each county was to receive eighty pounds per year; but when a president served for the whole colony, he received a hundred pounds. In addition to that, he always served in some other office for which he would earn perhaps fifty pounds additional. It is not certain that he received any fees in addition to his salary; but any that he may have gotten must have been of very slight consequence. At the same time, the governor of South Carolina was being paid five hundred pounds sterling as a fixed salary, with a hundred pounds for house rent, and about five hundred more in fees. ${ }^{44}$ Of course Georgia was a much less important colony than South Carolina, but the difference was not sufficient to account for a so much smaller salary for the governor. The first bailiff received slightly less than fifty-five pounds per year, while the second and third bailiffs were paid not quite forty-five pounds. When the Trust was surrendered, the bailiffs of Savannah were not acting as assistants for the province; but the first bailia happened to be the same as the president, though the offices were not united during most of the proprictary period. The assistants for the province were paid only twenty pounds each per year; but they might serve in other offices. For example, one of then acting as secretary of the province drew a stipend of fifty pounds. 'The recorder of the province got about thirty-two pounds; the register, twenty ; constables, ten, in Savanuah, and five dsewhere; while tithingmen were paid five each. ${ }^{45}$

It could not be expected that men would give their whole time to employments paying such nominal salaries. In the case of almost every officer except the president, his private means of making a livelihood took up the larger part of his

"Smith-South Carolina as a Royal Province, 77.

${ }^{45}$ B. 'T., Ga., XIII : 209. 
time while his official duties were exercised at comparatively rare intervals. Before leaving the subject of salaries, we may note with interest that after royal government was established in Georgia larger rewards for services were paid. For instance, the governor was paid the sum of six hundred pounds with perquisites amounting to nearly two hundred more. $^{46}$

During the closing years of the Trust the government in Georgia exereised considerably more power than it did when it was first established in 1743 . This was not a result of further grants of power by the Common Council, but it was made necessary by the exigencies of the situation. The Common Council, which was supposed to supervise and direct the Georgia officials, was meeting only twice a year; it was too occupied at those times with financial matters to give much consideration to government, and so the officers in the colony were obliged to exercise many functions that were designed to be retained in England. We may illustrate the tendency of the Georgia government to assume responsibility by the ehanges that took place in the manner of making land grants. All power to make grants of land was vested by the charter in the Common Council. Accordingly, when at first applications for land were made to the president and the assistants, they made recommendations to the Common Council, and the latter acted on each separate case. It was not long before the Council ceased to act on individual applications, but simply approved in a body all the recommendations that had been sent in by the board in Georgia. The next records show the mere mention that certain lands have been granted by the president and the assistants, and no formal action seems to have been taken in the Council; so that the later grants made by the Georgia authorities ${ }^{46}$ Jones-Hist. of Ga. I: 511 . 
are positive, without being conditioned on approval in England; ${ }^{47}$ and yet there is every reason for thinking that no definite grant of such authority had ever been made. 'This development of assumed power in the matter of land grants is typical of such powers in other particulars; and at the close of the proprietary rule there was in the colony a fairly influential de facto govermment in spite of the fact that there had been no nominal development in it during the nine years that it had been existing.

Thus far we have been dealing with exceutive government in Georgia abstractly without regard to those who administered it; but the personnel of the officers of the colony requires some attention before we leave the subject. It was a difficult task for the 'Trustees to select the first officials for the province. They had determined to conduct the government through the settlers sent over on charity; and, as these had not made a success of their own private affairs, it did not seem likely that they would achieve marked suecess in handling the larger affairs of a settlement, whether it be a single town or a whole province. Moreover, all the people were on a level at their setting out; and it was impossible to make any choice or distinction among them that might not be a possible cause of trouble in the future. ${ }^{4 s}$ The best that the Common Council could do, since it had been already determined not to send an experienced governor, was to choose such men as seemed most prudent and discreet, and to make provision for others to succed them in case the original appointees did not prove efficient. Accordingly, on November 8, 1739, they chose the following officers: Bailiffs, Peter Gordon, William Waterland, and Thomas Causton; Recorder, 'Thomas Christie; Constables, Joseph Fitzwalter

${ }^{47} \mathrm{C} . \mathrm{R} . \mathrm{VI}: 331,357,359$, as examples.

${ }^{48}$ C. R. III : 379 . 
and Samuel Parker; Tithingmen, John West and John Penrose; but it is interesting to see that eight individual deeds were scaled at the same time revoking the appointments just made and naming suecessors for the officers first named. At first thought, it might be confusing to find appointments immediately revoked, as was seemingly the case; but the fact evidently is that the last eight deeds were to be dormant until some of the first appointees proved unsatisfactory in some way, when they could be at once displaced by the commissions of others which had been to that time dormant. ${ }^{49}$ In addition to the officials mentioned, there were chosen eight conservators to keep the peace, who were Peter Gordon, William Waterland, Thomas Christie, Thomas Causton, George Symes, Richard Hodges, Francis Scott, and Noble Jones. During the first year, other minor officials were deemed necessary to meet the increasing population; and Henry Parker was chosen with others as a constable. ${ }^{50}$

Of the various appointees of the first year, very few were of any importance in the history of the colony; but four of them played somewhat prominent parts in the early government of Georgia. These were Causton, Parker, Jones, and Christie. Thomas Causton was the first to rise into prominence. He was appointed storekceper, and he used his position to advance himself rapidly in the colony. He was promoted by the Trustees to be second bailiff on October 16, 1734; and about a year later he was made first bailiff. ${ }^{51}$ He soon came to have the finest estate in the colony at Ocstead; ${ }^{52}$ and he was generally recognized to be the leading spirit in the province after the departure of Ogle-

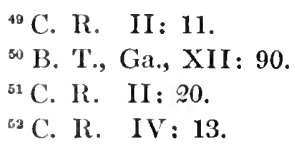


thorpe in 1734. It was Causton who drew all bills on the 'Trustees and directed affairs at Savannah during the next four years. He was not a popular official, and he succeded in getting the ill will and even active opposition of some of the best men in Savannah. The Trustees complained occasionally of his neglect in writing to them and in sending his accounts promptly; but they trusted him fully until the spring of 1738, when they found that he had gotten them into debt by several thousand pounds. They then suspected him of fraud and ordered his arrest, suspending him from his offices of storckeeper and first bailiff until his accounts were satisfactorily adjusted. The accounts never were completed; they were worked over by a committe for about eight years; and then Causton went to England to try to settle them in person with the Trustees. He was only partially successful and he was returning to Georgia in 1746 to complete the work when he died at sea. It was never proved that he acted with fratudulent intent in his dealings with the 'Trust; but it was undoubtedly true that he reaped a great deal of personal profit out of them and that he almost ruined the 'l'ust by his mismanagement. ${ }^{53}$

Henry Parker entered the service of the 'Trust as a constable on July 4, 17933. 'The next year he was promoted to be third bailiff, and the year following he becime second bailifi. In 1738 when Causton was deposed, Parker was given the position of first bailiff' of Savamals and he continued to hold that office until the charter of the colony was surrendered to the king. When the province was divided into counties, Parker was made first assistant for the County of Savannaly; and in 1743 he was made first assistant for the whole of Georgia. On Mareh 27, 1750, he was advanced to the office of vice-president, which had been created to give ${ }^{53}$ C. R. IV: 213. 
relief to President Stephens on account of his great age and infirmities. ${ }^{5+}$ On May 24 of the following year, Parker was made president of the colony and held the position when the government of England took charge of the province. ${ }^{55}$

Parker's character is clearly delineated in all the aceounts we have of him. He was strongly addicted to the habit of drunkenness, and it seems that he never overcame this handicap. He was a poor manager of his own affairs and was often reduced to want, his dress and appearance becoming despicable for service in his office. The neglect of his personal affairs was partly occasioned by his zeal for the eolony, for he was ever ready to serve the public when he was not under the influence of strong drink. ${ }^{56}$ In consideration of his poverty and services, the Trustees in 1738 gave him the use of two Trust servants and a gift of money additional to his salary. ${ }^{57}$ In his public service, he was acknowledged by his enemies to be a man of good sense and of an impartial temperament, though he showed no special initiative or strength of will. That he was comparatively easy to lead was evident in 1739 when a number of malcontents in Savannah got him to join with them in petitioning for negroes and changes in tenures, though he himself was not interested in the changes and knew that the petitioners were mainly bent on embarrassing the Trustees. As a punishment for his weakness in this instance, as well as his other shorteomings, the Trustees removed him from the offices which he held under them; ${ }^{58}$ but before the removal took effect, he was restored to office. His restoration was due to his acknowledgement of his faults and his

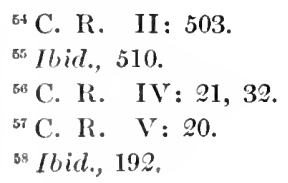


promise to make an effort to overcome them. ${ }^{\mathbf{5 9}}$

Thomas Christie was appointed to the office of recorder for Saranuah on November 8, 1732, and he continucd to hold the position until June $2 \%, 1739$, when he was appointed first bailiff to succed Henry Parker; but this appointment never went into effect, and in 1740 he was first suspended and then removed from the office of recorder which he had continued to exercise while waiting to become bailiff. ${ }^{60} \mathrm{He}$ then went to England and tried to excuse himself to the Trustees for the faults with which he was charged; but he was never able to regain their favor to the extent that he had previously enjoyed it. He was appointed naval officer at Savannah, but he took no further active part in colonial affairs. Christie's character was not above reproach. He actively identified himself with the discontented element in Savannah and caused much trouble for those whom he was scrving. He lived in open adultery, thus setting a bad example to the common people. He was careless and slovenly in kecping his books, and his accounts were not satisfactory. ${ }^{; 1}$ He is an instance of the unfortunate appointments so frequently made by the Common Council.

Noble Jones was also an appointec of the first year who early seemed likely to be a disappointment but later developed into a useful and highly respected officer. He was the surveyor for the colony and also acted as constable. There were many complaints against him as a surveyor; and in 1738 he was removed from that office and suspended from acting as first constable. ${ }^{62}$ When the war with Spain broke out shortly afterwards, Jones received the commis-

\footnotetext{
${ }^{60}$ B. T., Ga., Marț̣n to Parker, Mar. 25, 1740, Vol. IX.

co C. R. V: 391.

${ }^{21}$ Ibid., $234,236,243,260,324 ;$ C. R. IV : 476.

${ }^{62}$ Ibid., $21 \%$.
} 
sion of a lieutenant under General Oglethorpe and did good service in the siege of St. Augustine. After that expedition, he was appointed a captain in the militia service and was given the task of guarding Skidoway Narrows against a possible invasion from the Spanish. ${ }^{63}$ In 1749 he was given the command of the whole militia force of the colony, and to him was assigned the difficult task of disarming and quieting a disorderly band of Indians who had marched into Savannah intent on mischicf. ${ }^{64}$ He accomplished the work satisfactorily; and the incident gave him considerably more prestige than beforc. In 1750 he was made one of the assistants for the province, and the next year he was asked to act also as the register for Georgia. ${ }^{65}$

The next appointee of the Trustees who was destined to have a great deal of influcnce in the colony was William Stephens, who was chosen the first secretary of Georgia in 173\%. He was more prominently and influentially connected with the province during the last thirtecn years of the Trust than any other man in it. Comparatively little is known of his early life. His father was the licutenant governor of the Isle of Wight. Here the future Georgian was born in 16\%1. He was educated at King's College, Cambridge, and thought of becoming a lawyer; but he gave up this ambition. He was elected to represent the town of Newport in Parliament, and for twenty-six ycars he held this office, scemingly giving satisfaction, but making no great name for himself. Through acquaintance with Governor Horsey of South Carolina, he was induced to visit that province; and at the same time he went to Georgia to visit Oglethorpe, whom he had known in Parliament. Return-

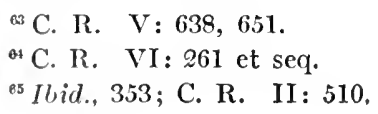


ing with Oglethorpe to England, he was in 1737 chosen secretary of the Trustees in Georgia; and he reported in Savamnah for duty on November 1 of that year. He was asked to serve from time to time on various committees and to fill several minor offices, giving great satisfaction to the 'Trustees both in them and in his regular work. When the colony was organized into counties in $1 \%+1$, Stephens was elected as the president of the Savannah government; and in $17+3$ he became the head of all the province. ${ }^{66} \mathrm{He}$ was seventy-two years of age when he assumed the responsible position as president of the colony; and by 1750 he was so enfeebled that the assistants hinted to him that he was retarding the affairs of the province. He consented that they should proceed without him, and he ceased entirely to exercise the duties of the office. Henry Parker, as we have seen, was to perform all the duties of president, holding the title of vice-president; ${ }^{6 \pi}$ but the next year Stephens on his resignation was relieved of even the name of president and was retired with a comfortable support from the Trust during his remaining days. ${ }^{6 s}$ He died a little more than a year after the charter was surrendered by the 'Trustees.

Stephens was a man of experience and sound judgment; and he was thoroughly honest in both public and private affairs. He served the Trustees faithfully, having at heart both their honor and the good of the colony; but he was not a suitable man to accomplish the work which was given him to do. As a correspondent, he was full, prompt and accurate; but he was a man of strong prejudices and rather narrow views both as to government and religion, and he was prone to impute sinister motives to those who differed

\footnotetext{
${ }^{86}$ B. T., Ga., XIII: 49.

${ }^{67} \mathrm{C} . \mathrm{R} . \mathrm{VI}: 332,353$.
}

${ }^{6 s}$ B. T., Ga., XIII : $18 \%$. 
with him. Knowing well the views of the Trustees as to land tenures, negroes, rum, and other points of dispute, Stephens fully accepted their attitude as his own, without seemingly making an unprejudiced investigation for himself. This was a great mistake, for the Trustees depended on him for the information on which to base their actions; and the fact that he tried to justify their rules rather than to view the effects of them impartially is probably the main reason why the Tristces persisted so long in some of their unwise measures. As an executive Stephens scems to have acted with courage and fairness. In this phase of his work, his weakness lay in his inability to arouse enthusiasm and active support among those whom he ruled. His lack of energy and magnetism may have been due to his age, but it was just as unfortunate for Georgia as if it had always been characteristic of him. In his private life he was a very humble, devout Christian; and he bore with fortitude the many sorrows and disappointments that eame upon him through his son 'Thomas and other members of his family.

The only other nomber of the executive government of proprietary Georgia whose connection with the province was of suficient importance to demand individual treatment was James Habersham. He eane to Georgia in 1737 with Whitefield, much against the wishes of his friends in England. He entered with Whitefield into the project of founding an orphanage; and he began the work of opening a school for children who might be eligible for such an institution, while Whitefield was raising the money for it. After the work lad gotten well under way, Habersham continued to be the active resident manager of the orphanage, showing ability both as a business manager and as an instructor of the children. ${ }^{69}$ In the absence of a minister at Savannah, Haber${ }^{\circledR}$ Stevens I: $346-35$ ?. 
sham read the service of the Church of England on Sundays. He did not get along well with the ministers of the English Church who followed Whitefield in Savannah, and he was severely rebuked by the Trustees in one of the longest and bitterest letters witten by them for interfering with the work of the ministers. In this letter they criticised also his ruming of the orphan house, saying that one of his fiery zeal was scarce fit to have in charge the training of children. $^{70}$ It is not clear what caused so severe a letter, but it seems probable that Habersham's desire to argue on questions of religion had been misinterpreted by Stephens and the ministers at Savammah as open opposition. It would seem that one so in ill favor with the Trustees would not be likely to hold important offices under them; but Habersham did not continue always in disfavor.

'The quality that won most favor for him with the Trustees was entire frankness, though his keenness of insight and his ability to express himself clearly and forcibly also commended him to them. They discovered these qualities in him almost by accident. For the pastor of the Salzburghers, he drew up in $17+6$ a careful summary of actual conditions in Georgia and the means necessary to remedy them. A copy of the paper found its way into the hands of the Trustees. It criticised their policies in nearly every matter of dispute between them and the colonists; but its facts and arguments were so strong and the tone of the paper was so fair, that the 'Trustees were much impressed with Habersham; ${ }^{71}$ and on January 19, 1\% 19 , they appointed him to be one of the assistants of the colony. He held the office of fifth assistant, and it would scem that it was created principally to give him a place in the management of the col-

${ }^{70}$ B. T., Ga., X: Martyn to Habersham, May 10, 1743.

${ }^{i 1}$ Stevens I: 310-311. 
ony. ${ }^{72}$ On March 19, 1750, when it had become evident that Stephens could no longer serve as secretary, Habersham was asked to take the office; and he held it until the surrender of the Trust. $^{73}$ During the last three or four years preceding the surrender, he was perhaps the most influential man in the colony, making suggestions both to the Trustces and to the officials in Georgia and giving freely of his time for the service of the province.

Other men for comparatively short periods of time were of considerable influence either for good or evil in the executive management of Georgia, but their terms of service were too brief for them to leave permanent impressions on the colony. On the whole. the appointees of the Trustees for executive work in Georgia were of mediocre ability and talents. It may be urged that they labored under such restrictions and limitations that they had no opportunity to show their talents; but it is more likely that if the officers had been able and magnetic leaders like Habersham, for instance, they would have been given fuller scope for the exercise of their abilities, and a larger portion of executive authority might have been vested in Georgia officers instead of its being retained in England. If Stephens in 1737 could have visualized the needs of the province and could have forcibly presented them to the Trustees, there is reason to believe that they would have immediately taken steps to establish a better colonial government and to satisfy the people of the province. The Trustees were led to believe that only a few malcontents were complaining and the lack of progress in the colony was due to them rather than to any fault in their own plans and regulations. It was too much perhaps to ask that Stephens or any other official should be

${ }^{72}$ C. R. II : 191.

${ }^{73}$ Ibid., 498. 
able by 1737 to comprehend the needs of the province and present them to the home authorities; but if the 'Trustees could have had early in the administration some frank, able officer, their action in the case of Habersham indicates that they would not have been unwilling to increase considerably lis authority.

There was great need for more power to be vested in the local government of Georgia. It was a severe hardship that many matters of the simplest kind could not be decided without being referred to England. Lack of regular communication with the Trustees often occasioned delays in bringing questions before them; they did not meet frequently enough to insure consideration of a question for some time after it reached England; and the reply of the 'Trustees might also be delayed. Besides, the solution of questions at such long range could not be satisfactory. Those making the decisions did so on theoretical grounds and frequently with a lack of sufficient information. A concentration of more power in the province would also have helped to make the people respect the executive authority of their magistrates, a result which was greatly needed. There was a general feeling on the part of both colony and Trustees that the situation was not satisfactory; but both parties were too inexperienced in affairs of government to discover just what was the difficulty. 


\section{CHAPTER VI}

LEGISLATIVE IIISTORY

THE vesting of legislative power in the people of the 1 various British provinces and colonies in America was not secured without many struggles. Some of these were long and bitter, but before the settlement of Georgia it seemed to be a generally accepted principle that in each colony the people should have some control over the making of their laws. Accordingly each British colony had its legislature pessessing more or less power; and a large part of the governmental history of any province consisted of a struggle between the people as represented in the assembly and the executive authority as represented in the Governor. Before the founding of Georgia, such disputes and controversies had become so general in all the colonies and they were so distracting in many cases, that we find the 'Trustees of the new province taking efficient measures to prevent a similar struggle in Georgia. In the charter establishing the colony and providing for its government, there was not a vestige of self-government provided for the people. Like all other authority, the legislative powers to be exercised in Georgia or concerning its affairs were vested exclusively in the Trustees.

They were granted unlimited power to make such bylaws, constitutions, rules, or ordinances as might be needful for the management and control of the corporation itself, and they were authorized to enforce all such regula- 
tions with suitable penalties, provided the rules and penalties be reasonable and not contrary to the laws of the realm. Every such law or constitution was required to be ratified at the annual meeting of the corporation in March of each year. ${ }^{1}$

The power to make the by-laws or rules just mentioned was a permanent one, but it is to be noted that such enactments usually concerned the management of affairs in England only. In addition to this authority, which might be exercised by any body corporate, the Trustees were given much greater legislative power. They were granted for a term of twenty-one years all the law making authority for the whole colony. 'They might prepare laws, statutes, and ordinances for Georgia without consulting the inhabitants or securing their approval; but the rights of the people were in a measure safe-guarded by the requirements that such laws must not be repugnant to the laws of the realm and that they must be approved by the king in council before they became effective. ${ }^{2}$ This regulation applied only to laws made by the Trustees. Since the charter mentioned no possible legislature of the people in Georgia, it made no provision for submitting laws made in the colony to the Privy Council, as had been ordered in the case of Pennsylvania and of other colonies.

For some time it seemed that the Trustees would not attempt any legislative work. No real laws were passed for several years. At the fourth meeting of the Trustees, a committee of seven was appointed to consider and propose laws and regulations for the colony, and some of the most influential men of the corporation were put on the committee-Oglethorpe, George Heatheote, Thomas Tower,

${ }^{1} \mathrm{C} . \mathrm{R}$. I: 17.

${ }^{2}$ Ibid., 19. 
Vernon, More, Hucks, and Laroche; but neither formal laws nor general regulations seem to have been reported to the Trustees as a body. ${ }^{3}$ It is possible that the committee formulated rules that were accepted without formal approval; but, if so, it is strange that some reference to them should not have been made in the journal of the corporation, which appears to be very full and accurate. The nearest approach to such a set of rules or regulations as we might expect for the settlement of a colony appears in certain articles drawn up as a basis of agreement with the Salzburghers who desired to settle in the province. These articles briefly stated that the Trustees would carry settlers to Georgia free of charge; would allow them money for tools; would furnish seed and give support until a harvest could be made in Georgia; would give to each man and his heirs male a house lot, a garden plot, and some farm land; would allow them all the civil and religious rights of the subjects of Great Britain; but would require of them obedience to such laws and orders as might be prescribed by Trustees. ${ }^{4}$

These rules are typical of all that were adopted during the first three years of the colony's existence. Instead of laying down general rules or establishing fixed principles that might be applied in the colony to all the cases of certain classes, the 'Trustees preferred to have each case presented to them for special consideration. As a rule, the conclusions of the Trustees in any case were sent to some representative of the Trust in Georgia in the form of an order for his enforcement. We may illustrate this form of legislation by noticing how the trustees dealt with the use of rum before 1735. Almost as soon as the colonists landed in Georgia, Oglethorpe wrote to the corporation that sev-

${ }^{3} \mathrm{C} . \mathrm{R}, \mathrm{I}: 70$.

${ }^{4}$ Ibid., $\%$ ธ- $\%$. 
eral of the people in the colony had died, and it was thought that the cause was rum. The Common Council immediately passed a resolution that the drinking of rum should be absolutely forbidden and that all brought into the province should be staved." 'This was a mere resolution passed quite hurriedly in a meeting of the ('ommon Council, not even at a general meeting of the corporation, and yet it had a binding force in the colony. Since it was so much quicker, and less troublesone for the time being at least, to legislate in this way than to pass formal laws with the approval of the Privy Council, it is no wonder that the 'Trustees used it in preference to the dilatory methods required in the latter.

The only hints we get of the legislative activity of the Trustees during the first few years are from their correspondence of the period. Rules or ordinances are casually mentioned in some of the letters that passed between the Trust and the colonists or correspondents in Germany; but they were not thought of sufficient importance to be ratified by the Privy Council or even to be inscribed in the minutes or jourmals of the Trustees.

By means of specific directions for each special case that arose and of a few general regulations as above mentioned, the affairs of the colony were eonducted until after Oglethorpe's return to England in 1734. It is evident that he impressed his fellow 'Trustees with the need of formal laws on some of the more important colonial problems; and on January 9, 1\%35, the committee on laws and regulations, of which Oglethorpe was chairman, made its first report. It recommended the passage of three acts, as follows: "An

${ }^{5}$ B. T., Ga., VIII : Martyn to Oglethorpe; Nov. $29,1733$.

"Ibid., Nartyn to Dumont, Apr. 6, 1731; also Martyn to DePfeil, July 4, 1734. 
Act for ren'ring the Colony of Georgia more Defensible by prohibiting the Importation and Use of Black Slaves or Negroes into the same"; "An Act to prevent the Importation and Use of Rum and Brandies in the Province of Georgia"; and "An Act for maintaining the Peace with the Indians in the Province of Georgia." The suggestions of the committce were generally acceptable to the Trustees. The proposed laws were all amended slightly; but they passed the corporation in much the same form proposed by Oglethorpe's committee. After being engrossed and formally approved, they were sealed with the official seal of the Trust. ${ }^{7}$ So far as the Trustees had authority, the acts were then complete; but, according to the terms of the charter, the approval of the Privy Council was necessary. This approval was sought by a petition of the Trustees; and it was granted on April 3, 1735, thus finishing the first and only real legislation for the proprietary province of Georgia. ${ }^{8}$

It is so remarkable that any colony could be run for twenty years with only three regularly enacted laws that we must stop to give a brief analysis of them. The act to preserve peace with the Indians was intended to regulate trade with the natives of Georgia. It laid a fine of one hundred pounds, with forfeiture of goods, on any person who might attempt to carry on trade with the Indians without a license from the agents of the Trustees. In order to secure the necessary license, each trader was required to appear in person at Savannah before a commissioner appointed by the Common Council; and he was further required to pay an annual fee of not less than five pounds, at the same time giving security for not less than one hun-

“C. R. I: 197-198.

${ }^{s}$ lbid., 31-54. 
dred pounds to be friendly with the Indians and to obev the rules of the Trustees. The licenses must be taken out each year; and rencwals, as original applications, could be secured only on the personal appearance of the trader before the commissioner. Traders were forbidden to give extensive credit to natives, nor were they permitted to carry on their business except in the towns or territory specifically named in their licenses. ${ }^{9}$

The act set forth in detail the powers and duties of the commissioners and other officials who should enforce the regulations. They might try minor cases growing out of complaints of the Indians, and they were fully authorized to execute their judgments. ${ }^{10}$

On the whole, the act seemed wise and reasonable. It was desired by the Indians themselves, and it was undoubtedly well adapted to prevent misunderstandings and harsh feelings between the English and the natives. So far as this object was concerned, the act was very successful; but it was so framed as to procure for Georgia the hearty jealousy and ill will of South Carolina. Before the settlement of Georgia, the traders of South Carolina had a practical monopoly of the English traffic with the Indians in the South. A considerable portion of this trade was carried on within the limits that had been assigned to Georgia, and the law of the Trustees forbade this trade unless licensed by their authority in Savannah. The South Carolina traders resented having to take the long journey to Savannah, and they felt aggrieved also that their long established traffic should be regulated by so new a province.

South Carolina sympathized with her traders, protesting against the Gcorgia law and attempting to nullify it.

${ }^{\circ}$ C. R. I : 40-41.

${ }^{10}$ Ibid., 34-35. 
The details of the controversy do not belong to this chapter. It is sufficient to notice that, whereas at first the people of the older colony were cordial and friendly to the prosperity of Georgia, they became estranged by the act to regulate commerce with the Indians; and the loss to the new colony of South Carolina's whole hearted assistance was a serious one.

The second of the acts passed in 1735 was intended to prevent the importation and use of rum and brandy in the province of Georgia. It was a formal enactment into law of what was already a general regulation of the Trustees. The prohibition of rum had been agreed upon by the Trustees because it had been the apparent cause of numerous maladies and fatal distempers among the settlers at Savannah. ${ }^{11}$ The measure was rendered still more imperative by reports of Indian chiefs to the effect that the use of liquors had caused great disorders among their people. ${ }^{22}$ The act, therefore, was regarded as a necessary protection of all inhabitants of the province.

According to the terms of the law, no rum, brandies, spirits or strong waters by whatever name distinguished might be brought into any part of the province of Georgia. All such brought in must be publicly staved. Any person preserving rum thus ordered staved would be fined five pounds above the value of the rum. ${ }^{13}$ If any persons should attempt to sell any rum either to Indians or to white people, he should be fined; for the first offense the fine was five pounds; for the second, the offender should be fined fifty pounds and become incapable of holding office in the colony. Half of cach penalty was to go to the informer and half to the col-

${ }^{11}$ B. T., Ga., VIII: Martyn to Oglethorpe, Nov. 22, 1733.

${ }^{2} \mathrm{C} . \mathrm{R}$. I: 4.

${ }^{13}$ Ibid., 45. 
ony. In order to prevent profane swearing, debauchery, and the like in public houses, it was provided that any retailer of wine, beer, or ale who should violate the rum act should be fined twenty pounds for the first offense and in addition his license to keep a public house might be recalled. In all matters of fines and penalties, the ('ommon C'ouncil of the Trustees was given supervisory powers. ${ }^{1+}$

The third important act of 1735 forbade the use of negro slaves within the limits of Georgia. The preamble recited that the law was passed because experience had shown that the settling of colonies with slaves had prevented the increase of whites, and that such colonies proved weak either for quelling tumults within or for carrying on external warfare.

To prevent this weakness in Georgia, after June 24,1735 , no negro should be brought within the province or sold or bought therein. Offenders should be fined fifty pounds, half to go to the informer and half to the colony. Any negro found within the limits of Georgia must be seized and adjudged the property of the Trustees and nust be disposed of for the bencfit of the provinee. ${ }^{15}$

However, if a negro ran away from South Carolina and was claimed by his owner within three months, the court at Savannah would adjudge the owner's right, provided he paid the costs of apprehending the slave, of keeping him until claimed, and of any damage that the negro might have committed.

In the case of fines and penalties under this act also, the Common Comncil might have the power of mitigating fines if it desired to do so. ${ }^{16}$ After the passage of the acts, the

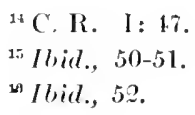


Council had printed a thousand copies of each of the laws for distribution both in the colony and in England.

There seems to have been a disposition among the Trustees to pass other laws for Georgia at this time. The task was committed to two of the Common Council to prepare an act for requiring a powder duty in the province and another for general sumptuary purposes to prevent the use of gold and silver in apparel, furniture and equipage in Georgia. ${ }^{17}$ Nothing seems to have been done in this matter at the time, but in 1737, while Oglethorpe was again at home, the following acts were ordered prepared: (1) A law for taking Indian evidence; (2) A law to regulate the manner of private persons giving to each other eredit and of suing for debts; (3) A law to regulate the wateh and to settle the militia; ( + A law to prevent the use of gold and silver in apparel and furniture and to prevent extravagance and luxury; (5) A law to oblige ships clearing out of the Savamnali and Altamaha rivers to pay a port duty of pistol powder, one pound of powder for every ton according to the tonnage of the ship. ${ }^{18}$ If any of these acts were ever passed or even referred to the Trustees by the committee appointed to consider them, the evidence is not available; but the fact that they were moved indicates a feeling on the part of some of the Trustees at least that the colony ought to be better protected by sufficient legislation. It is not unlikely that the matters thus considered were settled and the rulings enforced by the Committee of Correspondence, to whom it was customary to refer many such matters. ${ }^{19}$

The question of land tenures had been one of the most

$$
\begin{aligned}
& { }^{17} \text { C. R. II : } 97 . \\
& { }^{19} \text { C. R. I : } 980-981 . \\
& { }^{10} \text { Ibid., } 317 \text {, for example. }
\end{aligned}
$$


vexing problems that confronted the Trustees during the early years, and many investigations of the subject were made. By March 15, 1739, they were ready to legislate on the subject. A committee was appointed, as usual in such matters, to draft a law that would cover the views of the 'Trustees. 'The proposed law provided that all tenants in tail male in default of issue male might either by deed or by will appoint any daughter and her heirs male to succeed to his estate; or if he had no daughters, such a property holder might leave his estate to some one else. This general rule was adopted by the Trustces as a guide for their future action, but it was not passed as a formal law and so was not submitted to the king in council for his approval. 20

On July 25, 1739, the 'Trustees did attempt to pass formal legislation, however. An act was read and approved for appointing and regulating pilots to conduct ships into the larbors of Georgia; and for laying a duty on all ships brought in by the pilots; and for laying an additional duty on all such ships to be applied to the beacon on 'Tybee Island; and for laying another duty the proceeds of which might be applied to signals and other like purposes. After various amendments and considerations of the details again and again, it was passed to the Privy Council for approval. ${ }^{21}$ In due course the act was submitted to the Board of 'Trade, and this body reported the measure unfavorably. The 'Trustees thought that the report was made with personal animosity toward themselves; 22 but it is more likely that the Board of Trade was following its usual policy of disapproving duties in the colonies which might have a tendency

\footnotetext{
${ }^{20}$ C. IR. I : 315-346.

${ }^{21}$ Ibid., 355, 359.

${ }^{22}$ C. R. V: 390 .
} 
to restrict trade, and the report would doubtless have been made in the same way if Georgia had been a royal province. The Trustees placed the act in the hands of a conmittee for further consideration, but it seems to have met with the fate common to measures of the Trust which were unfavorably reported by the Board of Trade; for the Trustees were of the opinion that it would be unwise to change the act so as to make it acceptable to the British govermment.

On July 11, 1739, various details as to changes in the land tenures were agreed upon; and the question was raised in a meeting of the Trustees as to whether or not the terms should be embodied in a formal law to be approved by the king. It was urged by some present that the inhabitants had been led to expect such an act and that they might be disappointed, thinking that later 'Trustees could alter the action of the board as then constituted; but the majority of the Trustees thought it unnecessary to take such precautions. They pointed out that the charter gave to them the power to make such regulations as were proposed; and they asserted that if the rules were printed and had the Trust seal attached they might even be binding on successive Trustees. The members urging the latter course evidently wished to leave some way open of revoking the action taken if it proved unwise; and this would not be the case if the measures were approved by the king in council, for in that event the latter would be the judge of the expediency of revoking any law. ${ }^{23}$ The arguments advanced in the debate just mentioned seem to have been the ones that determined the gencral course of the Trustees in the matter of legislation; that is, to adopt with more or less formality orders or resolutions concerning colonial affairs, but to avoid all legislation that would in any degree depend on authority outside of ${ }^{23}$ C. R. V : $212-213$. 
themselves.

Their action regarding the enforcement of the rum act illustrates also this strong disposition to keep their affairs in their own hands. Early in $17+2$ it became apparent that the act had failed of its purpose and that rum was being freely imported into Georgia and used very publicly. The Trustees then wrote to their secretary in the province to wink at its importation and to discourage seizures of it, but to see that it was not sold except in houses licensed to sell beer. The Trustees hoped that the policy thus adopted would allow the act to become gradually obsolete without giving any public order on the subject, and they adopted the plan lest they might seem to be trying to repeal without the king's consent an act that had been approved by him. ${ }^{24}$

There is no apparent reason why they should not have applied for a repeal of the act which they frankly recognized to be a failure rather than to allow it to stand on the statute books and to encourage violations of it. So far as we can judge, it is one of the most reprehensible things in the usually honorable career of the Trust. The only excuse that seems at all available is that false pride made the Trustees unwilling to admit that they had erred in the original legislation.

After the exhaustive examination of Georgia affairs had been made in the spring of 1742 before the House of Commons, and the latter had determined that rum should be allowed in the province, the Trustees drew up a formal act to repeal the law of 1735 and presented it to the king in council for approval. ${ }^{25}$ The Board of 'Trade, having as usual to pass on the expediency of the repeal measure, re-

${ }^{24}$ C. R. V: 583.

${ }^{2 \pi}$ C. R. I: $54-56,398-400$. 
ported that they had no objection to the general tenor of the proposed repealing aet, but that they were unwilling for the Common Council of the Trustees to make any rules it chose for the purchasing and sale of rum, as the suggested law provided. The Trustees thought that they might still accomplish their purpose of retaining control in the colony by getting the magistrates invested with power to license publie houses as in England; ${ }^{26}$ and then of course these magistrates could be directed by the Common Council; but on further consideration the Trust decided to divide the proposed act into two parts and to present each part somewhat modified as a separate law to the king. ${ }^{2 \pi}$ These acts were approved by the law officers of the erown, but the Board of Trade again reported adversely on both of them on the general ground that they were too severe in their restrictions of British trade and in their penalties upon the people of Georgia. The Trustees were indignant that their efforts to earry out the directions of the House of Commons should be a second time rejected, and they determined to make no further changes in their aets. ${ }^{28}$ There were, however, some later negotiations with the Board of Trade on the subject, and the matter was agitated until the middle of 1745 ; but the laws were never approved, and the Trustees allowed the rum act of 1735 to be openly violated without further effort to repeal or modify it. ${ }^{29}$

In 1742 also the Georgia authorities prepared an act to change and regulate the land tenures in the province and it was presented to the king for approval at the same time that the first act for repealing the rum law was sent.

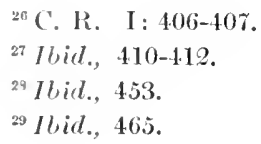


The law officers disapproved of the land tenure measure on the ground that it established within the colony two tenures of land. ${ }^{30}$ It was returned to the Trustees for their amendments or alterations; but they seem to have done nothing further in that matter also.

The only other formal act which the Trustees attempted to pass was prepared on August 8, 1750, for the purpose of repealing the prohibition of the sale or use of negroes in the colony. For eighteen years, the 'Trustees had bitterly opposed every suggestion of negro slavery; but those members of the Trust who were so hostile to the use of slaves were no longer in active attendance on its meetings, and the pressure from the colonists for negroes had become so strong and so general, that the Trustees determined to yield the point. An act was accordingly drawn in accordance with suggestions that had been made by prominent Georgians. Before the proposed law was adopted by the Trustees, however, they referred it to a mass meeting of the people of the province itself, in order that it might be sure to meet their approval." ${ }^{31}$ This was a most unusual concession for the managers of Georgia affairs to make; for, as we shall later see, there had been little inclination on the part of the 'Trustees to allow the people of Georgia any part at all in the control of their legislation. On this oceasion, the proposals of the Trustees were cordially approved by the people, and so the act was passed on to the king in council for final enactment into law. So far as the records show, it was never considered either favorably or otherwise by either the Board of Trade or the Privy Council; and it did not receive the approbation of the king

${ }^{30}$ C. R. I: 433.

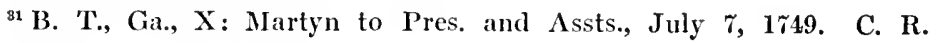
I : $56-62$. 
previous to the end of proprietary control. Though it did not become a formal law, its provisions were put into actual operation through the simple authority of the Trust itself.

It secms most remarkable that only three real laws were ever passed for the government of Georgia. We have noted numerous attempts on the part of the Trustees to pass others, and there is no doubt that the pcople of Georgia were eager that further legislation be adopted. The general reasons for the failure to pass other laws may be summarized under two heads: (1) the very decided preference of the Trustees for managing the province themselves and their fear that they would be unduly restrained by fixed acts which they could not readily change; (2) the difficulty encountered in passing laws through the opposition of the Board of Trade to so many proposals of the Trustees and also through the delays of executive action in the government of England. It would have been better for the province if there had been more genuine legislation and less government by mere orders from the Trustees or from the Common Council or from the Committce of Correspondence. It was very easy to send such orders or directions, and consequently they were frequently given without due consideration and without foreseeing always the results that would follow. These directions also could be given by only three members of the corporation, and it was quite often the case that this number did transact important business. General laws would have required the attention of more members; and, more important, it would have brought the Trustees into closer touch with the various organs of the British government. This contact would no doubt have been more or less provoking to the managers of Georgia, since it would have interfered with some of their plans and rules; but, if the latter had been earlicr criticised and opposed by the gov- 
ermment of England, the 'Trustees might have changed them earlier to the general benefit of the province.

Attention has been called to the fact that the charter gave no legislative rights to the people of Georgia and did not secm to anticipate that any such rights would be given during the twenty-one years that the Trustees would control the government of the colony. During the first nineteen years of the colony's existence, the people did have indeed an insignificant part in their own government. The failure to permit an assembly or other representative body for the people of the colony was no doubt due to the unhappy experiences that both the government of England and the proprietors of provinees had encountered in dealing with colonial assemblies. 'These generally exereised in America two functions; the making of laws and other regulations for a given province or colony was one of these functions, and the other was the self-imposed duty of protesting against grievances either real or imaginary. The first of these duties was exercised, as we have seen, by the Trustees of Georgia; and they hoped to escape the sceond activity of an assembly, but the protesting and complaining was done by the people of Savannah to a great extent. In this town there was general dissatisfaction and numerous complaints were made as to regulations adopted by the Trustees. Such protests were not organized or official in any way, however. The general method of protest was the circulation and signing of petitions to the Trustees, though in 17+1-1\% 12 the people went so far as to unite in appointing an agent to represent them before the British government. ${ }^{32}$ This action was not of itself legislation, but it was a step that looked to obtaining for the people of the colony some part in its govermment.

'The inhabitants of Georgia had almost no part in even ${ }^{32}$ C. R. V: 592-593. 
local matters. The nearest approach to local self-government during the first eighteen years of the colony occurred on August 6, 1739. On that day there was "a voluntary convention of the frecholders of Savannal for the purpose of drawing up regulations for the control of cattle in that region." The pindar, who had been appointed by Oglethorpe to care for the cattle of Savannah, summoned the convention and suggested various regulations that ought to be passed. The people themselves did little more than endorse his suggestions. This action was incorporated in a paper and signed by those present. ${ }^{33}$ This was only a trivial matter concerning a single community, and yet it was the nearest approach made to self-government in Georgia during the first eighteen years of the colony.

At length on March 19, 1750, the Committce of Correspondence suggested to the Common Council the advisability of establishing an assembly for the province. The reason assigned for the suggestion was the fact that Gcorgia had many scattered settlements and that it was very diffcult for the Trustees to secure information concerning these and concerning the colony as a whole. It was designed to be a sort of information bureau as well as a link to bind into a single unit the scattered sections of the province. ${ }^{34}$ Another reason for the establishment of the assembly which the Trustees did not mention openly and yet felt strongly was the desire to preserve Georgia as a separate province. They feared that, if their twenty-one years of government expired without there being any assembly in the colony to assert the independence of Georgia, South Carolina might succed in annexing the new colony. ${ }^{35}$ Whatever motives

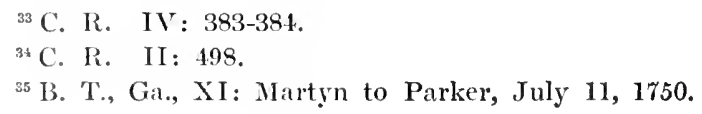


were strongest with them, the members of the Common Council were sufficiently impressed with the need of an assembly to act favorably on the suggestion of the committee.

The resolution adopted by the Common Council anticipated an annual assembly, but the Trustees seemed timid about committing themselves to a permanent arrangement, and so only a temporary assembly was called to meet in the year 1751. It was to sit at Savannah during the most convenient time of the year, the exact day being left for the President and Assistants to select; and its deliberations were to be completed within three wecks or a month at furthest. ${ }^{36}$

Representation in the assembly was to be based upon the number of families within given limits. Fvery town, village or district having ten families would be entitled to one deputy or representative; and, if there were units containing as many as thirty families, they would be entitled to two representatives. Special provision was made that Savannah should have four deputies, that August: and Ebenezer should have two each, and that Frederica should have two if thirty families were situated there at the time of the assembly. Details concerning the time of elections, the rules and methods for selecting delegates, and of dividing the colony into suitable districts for elections were left to the President and Assistants. ${ }^{37}$

As we have seen, the Committee of Correspondence had recommended the assembly to the Common Council and the latter had passed a resolution in its favor; but the formal appointment of the assembly was in the nature of a law, and that could be passed only by the Trustees sitting as a corporation. This formal action was taken on Jume 26,

${ }^{38}$ C. R. II : 498-499.

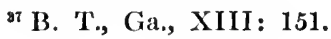


1750. The purpose of the representative body thus created was declared to be "to propose, debate and represent to the Trustees what shall appear to them to be for the benefit, not only of each particular Settlement, but of the Province in general." ${ }^{38}$ It was expressly declared that the assembly would not have the right to make laws itself.

As the people of Georgia were not acquainted with the methods for ehoosing delegates and for making other necessary preparations, the President and Assistants held frequent consultations in order to give the needful instructions and to divide the eolony into proper districts. On December 15, 1750, writs were issued for holding the elections, and the deputies who might be selected were ordered to report on January 15, 1751, in Savannah for the first meeting of the assembly. ${ }^{39}$

We have no information as to the methods of voting employed, nor do we know what were the qualifications for voters. These matters were left to the discretion of the President and Assistants; and it is likely that the heads of families in each district chose their deputy by a viva voce decision.

Obedient to the election writs, there gathered in Savannah on January 15, 1751, sixteen deputies from eleven districts as follows: From the Savannah district, Francis Harris, John Millidge, William Franeis, and William Russel; from the Augusta district, George Cadogan and David Douglass; from the Ebenezer district, Christian Reidlesperger and Theobald Keiffer; from Abereorn and Goshen districts, William Ewen; from Joseph's 'Town district, Charles Watson; from Vernonburg district, Patrick Houston; from Acton district, Peter Morell; from Little Ogeechee District, Joseph

$$
\begin{array}{ll}
{ }^{38} \text { C. R. I } ~ & 547 . \\
{ }^{39} \text { C. R. } & \text { VI }: 368 .
\end{array}
$$


Summers; from Skidoway district, John Barnard; from Midway district, Audley Maxwell; from Darien district, John Mackintosh.

The representatives from Savannah, Augusta, and Darien were leading men in the province. Those from Ebenezer were perhaps least known, and one of them had been recently aided by the government as a pauper. ${ }^{40}$ Most of the deputies were owners of five hundred acre tracts of land, but a few of them were not even freeholders.

The assembly was organized with the choice of Francis Harris, of Savannah, as speaker. He was the senior member of the leading commercial house in Georgia, and he was one of the wealthiest and most prominent men in the colony. After an exchange of courtesies between the assembly and the chief executive of the province, the deliberations for which the deputies had been summoned were begun. Efforts were started by some of the malcontents of the colony to create dissensions in the assembly and to interrupt its business; but none of the representatives appear to have been of the discontented faction, and the business of the colony was followed closely. ${ }^{41}$

During the first fifteen days of the session, the attention of the delegates was particularly directed to such matters as it was thought the President and Assistants in Georgia would be able to remedy. These were largely affairs of detail or of local importance. On January 30, the following list of grievances was reported to the President of the colony with the request that they be remedied:

1st. The want of a proper pilot boat.

2nd. The want of leave to build a wharf at Savannah, such building to be by subscription.

${ }^{10} \mathrm{C}$. R. VI: 183.

"13. T., Ga., XXIV: 40-41; XXV: 35. 
3rd. The need of standard scales and measures.

4ith. The need of a survey of the Savannah river.

5th. The want of an order to prevent ballast from being discharged into the river.

6th. The want of a commissioner to regulate pilots and pilotage.

rth. The need of a sworn packer and inspector to look after the produce of the colony.

8th. The want of a clerk of the market.

9 th. The need of proper regulations for the guard.

10th. The want of suitable officers to command the militia.

11th. The need of repairs on the court house.

The Georgia authorities agreed to redress all matters within their power, but they intimated that the purchase of a pilot boat was of so great expense that it ought to be referred to the Trustees. ${ }^{42}$

During the last nine days of the deliberations, the assembly was principally concerned with preparing for the Trustees a report on matters of general colonial interest. The conclusions of the deputies were embodied in a series of representations or addresses formally prepared, signed by the Speaker of the assembly, and sealed with the seal of the town court. The more important of these representations were:

1st. A complaint against Thomas Bosomworth for attempting to purchase Indian lands, and an urgent plea that private persons be forbidden to secure the reserved Indian lands near Savannah and on the coast islands.

2nd. A suggestion that the charter of Georgia be renewed if possible, and a strong protest against the annexation of Georgia to South Carolina, as the assembly under. stood had been suggested by some.

${ }^{42}$ Sterens I: 248-250. 
3rd. A request that the Trustees apply for a reduction of the quit rents.

4th. An account of the interest taken by the people of Georgia in the silk industry and the desire that the 'Trustees may continue to encourage it.

5th. An earnest petition that the assembly might have the power to make by-laws for the colony to be of force until the 'Trustees might disapprove of the same.

6th. The request that a court of cquity be established in Savannah to which persons who think themselves aggrieved by verdicts of the town court night appeal.

7th. The desire that the negroes who were already in Georgia before slaves were duly licensed and that those who might be brought from South Carolina or other colonies be freed from the duty on slaves proposed in the negro act of the Trustees.

8th. A request for a substantial pilot boat to rescue distressed vessels on the coast and also for an engine to extinguish fires in Savannah.

9th. The desire that conservators of the peace and constables be appointed in those districts which had none; and also that a small body of soldiers be provided to protect the beaten paths into Spanish and Indian territories.

10th. A complaint that one company in Augusta had secured a monopoly of the Indian trade and a request that steps be taken to break its power. ${ }^{43}$

The Trustees either fully complied with or approved all but three of the representations above mentioned, but the three rejected were of great importance. They refused to allow the assembly to make by-laws even of the most temporary sort, though they promised to act promptly on any suggested legislation that the assembly might from time to ${ }^{43}$ C. R. II: 557 et seq. 
time propose. They also refused to allow equity courts in Savamnah. They thought that the establishment of such courts would encourage vexatious suits at law. Dissatisfaction with the decisions of the town court might be appealed to the Trustees, they asserted, without cost; and that ought to be sufficient to insure justice to any one. In both these cases, the real secret of the action of the Trustees was the feeling that they constantly showed; namely, that they themselves were best able to care for the affairs of the colony and that they ought not to relinquish any essential part of their authority over the province. The third matter in which the Trustees refused to act in accord with the wishes of the Georgia assembly was the desired release of duties on all negroes except such as might be brought from foreign countries. The 'Trustees did not want slaves at all in the colony, and they very naturally would not make it easy for them to be brought in; so that their action on this matter was to be expected. ${ }^{44}$

On the whole, the Trustees were pleased with the results of the assembly. It had been established for only one year as an experiment, but in 1751 it was definitely constituted as a permanent body. It could hardly be called a part of the colonial government, for it had no real power; but was at least a part of the provincial machinery. No important changes were made in the general plans for the assembly; but the qualifications for deputies were made much stricter, as had been contemplated from the first. After June 24, 1751, no person could be elected to represent a district in the assembly who had not one hundred mulberry trees planted and properly fenced upon every tract of fifty acres which he possessed; and after June 24th, 1753, no one would be eligible to act as deputy who had not strictly conformed ${ }^{44}$ B. T., Ga., XI: Martyn to Parker, July 10, 1751. 
to the linitation of the number of negro slaves held in proportion to his white servants, and who had not in his family at least one female instructed in the art of reeling silk, and who did not annually produce fifteen pounds of silk for every fifty acres possessed by him. ${ }^{45}$ It is evident that one might meet all the prescribed qualifications without being in reality at all suitable to represent his district in the assembly; for the whole emphasis of the 'Trustees' regulations was put upon the raising of silk in Georgia. As a matter of fact, there was not in Georgia any inhabitant who did conform to the full requirements of the Trustees either in 1751 or in 1753 ; but before another assembly was summoned the 'Trustees had determined to resign their control of the province, and the second meeting was never called.

Thus the proprietary era closed without leaving to the people of Georgia any semblance of legislative power. If the Trustees had remained in authority for twenty years longer, it is probable that the colonists' assembly would have been able to gain real power. In many of the other English colonies, the people secured their legislative powers only after bitter controversies with the authorities at home and after repeated and urgent petitions had been made. Proprictary rule was too brief in Georgia for this process to be worked out.

On the whole, the 'Trustees were not successful in their legislative activities. Most of the acts they proposed failed to gain the approval of the British govermment. 'The laws that they did pass were detrimental to the peace and prosperity of the colony. If they had taken the inhabitants of Georgia into their confidence at the beginning, and if they had established then an assembly like that of 1750 , it is probable that the colonists might have aided in the solu${ }^{45}$ C. R. II : 499-500. 
tion of their own problems; but the Trustees waited until it was too late to be of service to them to establish the colonial assembly. 


\section{CHAP'TER VII}

ORGANIZATION AND DEVELOPMENT OF THE JUDICIARY

T $\mathrm{N}$ the previous chapters of this work, some attention has 1 been given to the exccutive and legislative features of the proprietary government of Georgia. The present chapter undertakes to outline the judicial system of the province and to explain its practical workings. While we shall find that many of its regulations differed widely from those of the other British colonies in America, these peculiarities were not particularly noticeable in the charter itself. It gave to the general corporation of the Trustees the power to create such courts as might be necessary for the province. These might be courts of record or not as the Trustees preferred. 'They were authorized to administer oaths, or to require solemn affirmation, for the discovery of truth; and they might hear and determine all causes whether civil or criminal. The charter made no provision for appealing cases to the Privy Council from colonial courts. The appointment of all officials who should operate the judicial machinery of the province was vested in the Common Council of the Trustees. While the Trustees thus had complete control of the judiciary in Georgia, justice was not to be administered in the colony in their name, but in that of the king. The most remarkable feature of the charter provisions was that which limited the authority of the Trustees in all judicial matters to a period of twenty-one years from the giving of the charter, after which time the king would assume entire 
charge of the system. ${ }^{1}$

Acting under the powers thus granted by the charter, on Novenber 2, 1732, the general corporation of the Trustees established a court of record for the first settlement that should be made in the province. This was to be known as the town court. Its territorial jurisdiction was limited to the town and precincts of Savannal, which was the first settlement established in the colony. The judicial officers in charge of the court were three bailiffs and a recorder, whose duties will be considered later. The powers of the court were very extensive indeed. It could try offenses against the national government, such as concern the federal courts of the United States at the present time; these crimes would include treasons, insurrections, rebellions, counterfeiting, clipping, or falsifying British money, and the like. The court was also authorized to try and punish ordinary criminal offenses; such as murders, burglaries, rapes, thefts, cheats, swindles, and all other felonies and misdemeanors, whether the offenses were against statute or common law. Nor was the town court limited to criminal matters. It was empowered to hear and determine all suits and actions, real, personal or mixed, concerning debts, accounts, trespasses, contracts, and all similar causes whatever. After such civil cases were determined, the court was further authorized to issue and enforce exceution of its decrees. All juries, panels, attachments, warrants, judgments, and other processes were to be served and executed by the two constables of the town, or by their assistants who were known as tithingmen. All the proceedings of the court must be in the English tongue, and records of them must be plainly written. ${ }^{2}$

The functions exereised by several English courts were

${ }^{1}$ C. R. I : $\stackrel{2}{ }$.

${ }^{2}$ B. 'T., Ga., XII : 14 et seq. 
thus merged into one; but for a single town or settlement there was little disadvantage in that arrangement. It would have been absurd for a too highly organized judicial system to be established for a town of a few hundred settlers. No provision was made by the Trustees in their regulations for a court of appeals, though it was generally understood that any dissatisfaction with the judgments of the Savannah court would be referred directly to the Trustees themselves.

For the administering of justice in the new court, the Common Council appointed promptly the four officials, three bailiffs and a recorder, contemplated in the regulations of the Trustees. They likewise appointed two constables and two tithingmen for the town. The bailiffs were distinguished by the designations of "first," "second," and "third"; but the first bailiff was not more powerful than the others. He usually presided at trials, and he was more often expected to administer oaths; but the distinctions between the bailiffs were largely for convenience only.

The instructions issued to these officials were astonishingly meager. They were directed to hold office until their successors were appointed. The bailiffs and recorder were admonished to preserve the peace and to administer justice impartially; while the constables and tithingmen were directed to obey the magistrates. It seems to have been assumed that the duties to be exercised by these officials in Georgia were the same as those of similar officers in England and that these were well enough understood to require no further instructions. ${ }^{3}$ As a matter of fact, each officer in the new province was to have vastly more power and much more complex dutics than an officer of the same title in England; and the Trustees would have acted more wisely if they had been more specific in giving their instructions to the new ${ }^{3}$ B. T., Gia., XII : 17 . 
appointees.

Before the first settlers sailed for Georgia, the Common Council also named eight officer's who were styled conservators of the peace. These were not provided for in the general constitution of the town court. Their commissions gave them power only to require bond from persons threatening injury or damage to others, or to imprison such persons if bonds could not be provided by them. It is not clear whether or not these officials had the powers of English justices of the peace to try minor civil cases and to bind over accused persons for trial by the town court. Conservators of the peace were recognized as having such authority at a later time, and it is probable that from the first it was tacitly understood that they should exercise it. It is worthy of note that in the first appointment of conservators the three bailiffs and the recorder of the town court were four of the eight appointees. ${ }^{+}$

As the outlying precincts of Savamnah were settled and as people began to live without the limits of the town itself, the territorial jurisdiction of the town court was enlarged to include all the settlements in the neighborhood. For instance, in 1738 the village of Thorpe was laid out; and it was included within the precinets of Savannah for the express purpose of putting its people under the protection of the court already established. Constables and tithingmen were appointed for the new village; but no new bailiffs were chosen. ${ }^{5}$

This enlargement of the territory eovered by the town court was not indefinitely increased. The Trustees did not intend for it to become a provincial tribunal. In 1735 when the town of Frederica was established at the mouth of the

* B. 'T., Ga., X II : 21 .

${ }^{5}$ Ibid., 104-105. 
Altamaha River, a separate and distinct town court was adopted for it. 'The constitution of the court, with its jurisdiction, powers, and officials, was identical with that of Savannah; but there was no connection whatever between the two. ${ }^{6}$

After 1735 there seem to have been no enlargements of jurisdiction or creation of new courts until the government of the whole province was reorganized in $17+1$. With this new order of things, came several changes in judicial matters that were quite important. Before this time, there had been no executive officials in the province. All the duties of an executive character had been performed either by special commission from the Trustees or by the bailiff's who were primarily judicial officers. In 1\% 1 , however, the province was divided into the two counties of Savamah and Frederica; and in each county there were to be a president and four assistants, who were intended to exercise executive functions. The new arrangement would apparently bring about a separation of judicial and executive powers; but there were two things that prevented this. In the first place, three of the four assistants in each county were to be bailiffs of the town court of that county. The same persons would engage in both executive and judicial business as before; but after $17+1$ they would be called assistants while engaged in the former work and bailits when doing the latter. Again, the president and his assistants as a council or boand were granted appellate jurisdiction over cases from the town court when the amount involved was as much as twenty pounds. In the same general regulations, it was provided specifically that appeals could be taken to the 'Trustees where the amount involved was as much as one hundred pounds, though in all cases of appeal either to the president and '13. 'T., Ga., XII : 243-247. 
assistants or to the 'Trustees, the appellant must give bond to answer for the costs and damages. ${ }^{7}$ While it was not definitely so stated, it seems to have been understood that appeals to the Trustees could be taken directly from the town court as well as from decisions of the president and his assistants; and it is probable that in most cases of one hundred pounds or more appeals would not be taken to the appellate courts in Georgia at all unless there were pressing need for an immediate decision.

It is not to be understood that there was in Georgia as yet a provincial system of courts. The president and assistants of each county had appellate jurisdiction only over cases arising in the Savannah or in the Frederica town courts respectively; and only the Trustees themselves as a sort of supreme court afforded any link between the organizations of the two counties.

While in 1741 Georgia was thus divided by law into two counties, and while the regulations above outlined applied to both of them equally, yet the laws were not put into active operation in southern Georgia by the appointment of the proper officials to carry out the law. The matter was postponed until 1743 when the president and assistants of Savannah county were appointed to act for the whole province. $\mathrm{S}$ This action gave to Georgia a single appellate court and in a measure consolidated and centralized the judicial system of the colony. The province was divided into counties each having a town court, from which appeals could be taken either to the president and assistants as a council for the whole colony or to the Trustees as a court of last resort.

This apparently satisfactory arrangement was not long continued. For reasons to be given later, the town court of

${ }^{7}$ B. T., Ga., XIII: 15 et seq.

${ }^{8}$ B. T., Ga., XII : 49. 
Frederica was suspended: and at the same time the appellate jurisdiction of the presidents and assistants over cases not only from Frederica, but also over those from Savannah, was likewise suspended. In point of law, the whole system reverted to the conditions which existed when Savamah was first settled. At that place there was a town court, with a few conservators of the peace and nothing more. ${ }^{9}$ 'The suspension of the colonial system was intended by the Trustees to be only temporary; but it continued to the end of their control. Almost no changes in the judicial administration were made between 1745 and 1752 except the appointment of minor officers in various parts of the province. After 1750 the second and third bailiff's of Savannah did not regularly act as provincial assistants, though oceasionally one of them did so as a temporary expedient. ${ }^{10}$

In 1751 when the assembly met to consult about the general welfare of the colony, it petitioned the Tyustees to establish a court of equity at Savamah for hearing cases in which the common law did not afford adequate remedies. The president and the assistants of the colony advised the Trustees that the court was not needed, and it was not established. The 'Trustees objected to it on the ground that appeals to such a court would be expensive while they cost nothing when made to themselves. They admitted that an equity court might give to the colony a certain degree of credit among people at a distance, but they thought that the increased litigation and expense would more than off set the adrantages. ${ }^{11}$ The same assembly petitioned for conservators of the peace to be established at various points in the province, and this request was readily granted by the

${ }^{8}$ B. T., Ga., X: Verelst to Stephens, Feb. 6, 1766.

${ }^{11}$ B. T., Ga., XIII: 209.

${ }^{11}$ 13. T., Ga., XXIV: 48. 


\section{Trustees.}

No admiralty court existed in proprietary Georgia, though in 1748 an effort was made to have one established. The movement to secure it started from an assertion on the part of the Trustees of their right to make all official appointments in Geor gia. The commander of Oglethorpe's regiment at Frederica had recommended to the Admiralty Board the appointment of Mark Carr as judge of the court of admiralty in Georgia, apparently not realizing that no such court had been created. The Trustees heard of the reconmendation and they immediately notified the Lords of the Admiralty that, while they approved of the particular nominee, they reserved the right to make all appointments in the province. It soon developed, however, that no viceadmiralty powers had been settled for Georgia, and so no judge could of course be appointed. The Trustees then made a formal petition to the king in council for the establishment of a vice-admiralty court, especially for the purpose of condemning prizes captured during the war; but nothing seems to have been done in the matter. ${ }^{12}$ It is probable that the coming of peace at an early date made the court seem less necessary than it would have been, and the Trustees ceased to urge its establishment.

The preceding pages treat of the general constitution and development of judiciary in Georgia from a theoretical viewpoint only. We shall now examine the practical workings of the system. Under this topic, we may first consider the part played by the Trustees themselves in the actual administration of justice in the province. Before the settlers set out for Georgia on the first embarkation, the 'Trustees had several quarrels and disputes to settle. ${ }^{13}$ 'There

${ }^{13}$ C. R. I: 507-512.

${ }^{13}$ Lbid., 109-110, 137, as examples. 
was no legal warrant for their doing this, but they acted as a sort of arbitration board, enforcing their decisions by refusing to allow settlers to go to Georgia until they had complied with the judgment of the 'Trustees in the matters heard.

They required regular reports of all proceedings in the colony, at first demanding these to be sent monthly and later calling for them quarterly; and they read these with more care than colonial matters of the other provinces were wont to receive from the British ministry. The Trustees had much difficulty in getting regular reports of the court proceedings until William Stephens was sent out as their secretary. He sent them with great regularity informal accounts of what was done, and he was aetive in seeing that the official records were also forwarded. None of the oficial reports are now available for this period, but the minutes and journals of the 'Trustees indicate their general poliey toward the colonial judiciary.

They superintended eren the smallest details of judicial business. It is impossible to emumerate fully all the matters of a minor nature that they directed; but examples are, appointing a guardian for a single orphan, ${ }^{14}$ ordering the release of individual prisoners on habeas corpus proceedings, ${ }^{15}$ directing that specific persons have information of the charges against them. ${ }^{16}$ 'These and other similar directions which they sent to the officials in Georgia indicate that the Trustees, or a committee of them, reviewed carefully every case reported to them.

The 'Trustees heard appeals from the courts in Georgia; and, while this topic will be more fully treated in another

14 B. T., Ga., XII: 161.

${ }^{15} \mathrm{C}$. R. I: 493.

${ }^{10}$ B. T., Ga., IX: Verelst to Williamson, Dec. 4, 1737. 
part of the chapter, we may note here that nearly every appeal received prompt attention. There was a tendency on the part of the Trustees to uphold the decisions of the colonial judges whenever this was possible, though they did not hesitate to interfere when they thought the bailiffs were failing to give justice. ${ }^{17}$

One of the troublesome tasks that frequently confronted the Trustees was the settling of disputes between the magistrates themselves. These did not arise in the ordinary course of judicial procedure, being in most instances private jealousies and disagrcements; but the settlement of them was of vital importance to the successful administration of justice in the colony, and of course there was no tribunal in Georgia with jurisdiction over such disputes. Sometimes the matters were settled without a personal hearing before the Trustees; each side would present a written statement of the situation, and the Trustees could determine the matter from that evidence. ${ }^{15}$ It was more frequently the case that a written statement would be made by the plaintiff or accuser only, while the defendant would deem it best to appear in person to plead his cause. ${ }^{19}$ In at least one case, both the accused and the accuser were summoned to appear before the Trustees, and a formal trial was conducted. ${ }^{20}$ It is a little remarkable that in every case where a magistrate appeared in person to defend himself, he was either entirely or practically exonerated by the Trust. This is not to be explained so much by the weakness of the Trustees or their leniency as by the fact that the Georgia bailiffs were quarrelsome and prone to make charges against each other that

${ }^{17} \mathrm{C} . \mathrm{R}, \mathrm{I}: 420$.

${ }^{18}$ B. T., Ga., Verelst to Ogletliorpe, Apr. 27, 1741.

${ }^{19} \mathrm{C} . \mathrm{R}$. II : $437-442$, for example.

${ }^{20} \mathrm{C}$. R. I : $4 \tau 6$ et seq. 
could not be established by sufficient proof.

'These hearings or trials between Georgia magistrates were held before the corporation of the 'lrustees as a whole rather than before the Common Council, and there seems to be no good reason why this should be true; for the Common Council had exclusive control over the appointing or removing of officials in the province, and it would seem that it should have investigated the charges agilinst its appointees. When a magistrate was accused of some serious matter, it was customary for the Common Council to suspend him as a colonial officer until the charge against him conld be cleared. After he was freed from the accusations preferred against hin, sometimes he would be restored to his former position, but this was not always the case. An exonerated magistrate was nearly always given some consideration for the trouble to which he was put; sometimes he was restored to office and given money compensations; sometimes the latter only was given. ${ }^{21}$

The subject of appeals deserves consideration more from the fact that so many changes were made in the laws affecting them than from the number of cases that were actually carried to higher courts. Before $17+1$ and after 1745 , there was no appellate court in Georgir; and during the brief period of about four years when appeals were allowable within the province, there do not seem to have been many instances when the opportunity was used. For much the greater part of the proprietary period, appeals could be taken only to the Trustees, unless the Privy Council might be considered an appellate court for the province. 'The president and assistants would scem to be ill suited to compose a court of appeal, for three of the five members would be bailiff's of the town court from which the appeal was ${ }^{21}$ C. R. II : 474-475, for example. 
taken; and yet the appellate court reversed the lower one in some cases at least. ${ }^{22}$ This court acted with expedition, sometimes finishing the matter of an appeal in a few days after it was made.

Most of the affairs that were appealed to the Trustees seem to have received speedy and satisfactory settlements, as few complaints are recorded against them; but in at least one case, that of Clee against Minis, the appellant complained that for two years he had gotten no satisfaction, and he threatened to publish his grievances both in England and in America, asserting that he had been denied the rights common to all Englishmen. ${ }^{23}$

There seems to have been only one case from Georgia that was formally appealed to the Privy Council before 1759. It grew out of the prosecution of an Indian trader by the name of Joseph Watson who was accused of stirring up the Indians and of causing either directly or indirectly the murder of one of them. It seems that he was at first indicted for murder, but that eharge did not come to trial, so far as we can tell. The accusation on which the trial was actually held was that of exciting the natives to crime. The magistrates evidently felt that an example was needed to warn white people to be careful in their dealings with the Indians; for all the accounts of the court proceedings indicate that Watson was scarcely given justice. When a verdict was finally reached by the jury, it found Watson guilty of using unguarded expressions, but recommended him to the mercy of the court on the ground that possibly the defendant was not of sound mind. Causton, who was the presiding magistrate, is represented as sending back the jury several times with the order that they change the verdict to one of lunacy;

${ }^{22}$ B. T., Ga., XXIII: 17; C. R. VI: 103-104.

${ }^{23}$ B. T., Ga., XXIII: 17 . 
but the jury did not alter their original verdict. Instead of sentencing him for the crime of which he had been found guilty, Causton ordered Watson into confinement as a lunatic. The wife and other friends of the imprisoned man protested against this order, but their efforts were in vain."

The case was reported in such a light to the Trustees that they were very indignant at Watson for disturbing the Indians whom the Trustees were anxious to keep on the terms of closest friendship. They sought legal advice to ascertain the limit of the punishment that might be inflicted upon him for his offense. They approved the action of the magistrates in keeping him in prison, asserting that they thought he had been dealt with in mildness. They also laid down the gencral rule for the future that any offender against the Indians should be dealt with very severely. ${ }^{25}$

Mrs. Watson was unwilling that her husband should remain in jail under what she thought to be a false accusation, and she became active in his behalf. Appeals were made in vain to the Trustees who firmly upheld the magistrates without feeling that it was necessary to investigate the matter further. Their failure to investigate was due to the fact that they had received a full report of the case in the first instance from Causton, and they did not hesitate to accept the account that he gave without realizing that he might be biased in his statement of the proceedings.

When Mrs. Watson failed to get relief from the 'Trustees, she appealed to the king in council for the relcase of her husband. On March 22, 1737, the Privy Council requested from the Trustees an answer in writing to the petition of Mrs. Watson. ${ }^{26}$ The Trustees ordered that a reply be pre-

${ }^{24}$ Brief Account of the Causes, Ga. Hist. Collec. II: 132-136; True and Historical Narrative, Ga. Hist. Collec. II : 201.

${ }^{25}$ B. T., Ga, XII : $138 . \quad{ }^{20}$ C. R. I: $27 \%$. 
pared, and they sent immediately to Savannal asking that the magistrates prepare the necessary affidavits and a full statement of the whole case. ${ }^{27}$ Without waiting for the information to arrive, however, the Trustees prepared a representation on the subject to be laid before the Privy Council. At this point a very interesting question was raised; namely, whetlier this answer would commit the Trustees to the policy of beconing parties to suits from Georgia and whether the answer would be a precedent for requiring the Trustees to allow appeals from the colony in criminal cases. Before they laid their representation before the Privy Council, the Trustees submitted these questions to the attorney general for his opinion. ${ }^{2 s}$ We do not have a statement of his opinion; but a safe inference from what followed would be that he advised the Trustees that an answer in this case would be a precedent for their filing answers to future suits, if there should be any. At all events, the Trustees instead of filing their statement of the ease with the Privy Council hastened to settle the matter out of court. They had ordered an investigation of Watson's sanity; ${ }^{29}$ but before they had time to hear from this investigation they sent an order for the unconditional release of the prisoner. ${ }^{30}$ The action of the Trustees in this case looks like a plain instance of yielding ground in order to avoid a controversy with the Privy Council over the question of jurisdiction in appeals from Georgia.

This release of Watson ended all judicial action in the most noted case of the proprietary period of Georgia. It has been treated in some detail beeause it offers an oppor-

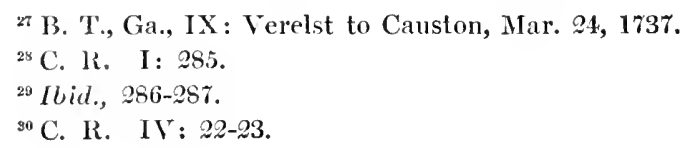


tumity for looking closely into the general attitude of the magistrates in Georgia, of the Trustees, and of the Privy Council, toward the administration of justice in the colony.

Attention has been called to the fact that the town courts of Georgia were to be condueted by three bailiffs and a recorder, and that very large powers were entrusted to these officers. From a practical standpoint, justice was not well administered by them during the earlier years of the colony. 'This was not so mueh the result of a bad constitution of the courts as of inefficient officials to administer the plans of the 'Trustees. The position of bailiff did not require a man with legal training, and there seems to have been no one thus trainced who held the position during the proprietary period. The prime requisites for the work were faithfulness, honesty, good judgment, and the confidence of the people. The 'Trustees realized that suitable men for bailiffs were scarce, and they frequently made their appointments with the knowledge that the appointees were by no means ideal, though the best available at the time. Some of those who were chosen for the position could not read or write, and most of them were inexperienced in judieial matters. It is remarkable that the 'Trustees did not give explicit directions or instructions to these officials whom they knew to be at a disadvantage in their new work; the magistrates repeatedly mention in their correspondence that such instruetions had not been given. Besides, for years there were in the colony no law books of any description from which the bailiffs could gain information; hut this need was supplied by the Trustees early in 1741.31

One of the difficulties that hampered the adninistration of justice both at Saramah and at Frederica was the fact

${ }^{31}$ 13. T., Ga., XXI: Stephens to Verelst, Aug. 4, 1740; C. R. V: 429. 
that the magistrates themselves were quarrelsome. There were petty divisions and jealousies among them in both parts of the province: and this made hearty co-operation in the prosecution of erime or in other judicial matters almost impossible. Still another handicap that faced the officers of the town courts was the lack of confidence in them which the people freely exhibited. This was partly a natural result of the dissensions among themselves; they could not hope to impress the colonists with their fairness and dignity when they engaged in petty disputes even on the bench. ${ }^{32}$ Again, the officials of Georgia were on a level with the other inhabitants in education and experience, and sometimes beneath many of them in wealth and social position, so that the people were more or less restive at being judged by those whom they felt to be no better qualified than themselves. Accordingly we find criminals deriding constables and tithingmen, ${ }^{33}$ peace officers defying the bailiff $s,{ }^{34}$ and Indian traders insulting all the judicial anthorities. ${ }^{35}$ In order to impress the dignity and authority of the court upon the people, the Trustees sent to the magistrates of the town court of Savannah official robes to be worn when upon the bench. ${ }^{36}$ This device was worth something as a temporary expedient, but it had no permanent value. It was not until the magistrates had had years of experience and had ceased to be so jealous of each other that the courts were respected and their decisions accepted with satisfaction.

There were no lawyers in the colony. It is generally held that these were excluded by order of the Trustees, though

${ }^{32}$ C. R. IV Supplement: 24 et seq.; C. R. V: 402.

${ }^{33}$ C. R. IV: $58,388$.

${ }^{34}$ Ibid., 147-153.

${ }^{35}$ Ibid., 641-643.

${ }^{8 \theta}$ C. R. II : 208 ; B. 'T., Ga., IX: Verelst to Causton, Aug. 11, 1737. 
no order to that effect seems to have been issued. However, it is probable that they would desire the exclusion of lawyers, because they took every precaution to prevent undue litigation, and the presence of lawyers was thought at that time to promote suits and legal disputes. In the earlier years, the rule against the practice of law seems to have been vigorously enforced. As late as $1 \% 40$ a man named Williamson who even claimed to have the permission of the Trustees to practice as an attorney was warned that he must not attempt to do so; and, in spite of the fact that he had been engaged as a solicitor in a case or two, he thought it safer not to persist in the matter. ${ }^{37}$ In later years a man named Watson established a law office in the colony and did a thriving business, especially anong the Indian traders who were notoriously litigious. His practice was carried on somewhat surreptitiously and was not approved by the authorities either in England or in the colony. ${ }^{3 s}$

The lack of attorneys was sometimes an inconvenience, for difficult points would puzzle the magistrates, who were without law books and without authorities to guide them and who could hardly wait to send to England for advice. In such cases, it was customary for them to secure in Charleston the advice of a lawyer. and this seems to have been a fairly satisfactory arrangement. ${ }^{39}$

In pleading cases in Georgia, each party was supposed to be his own advocate in civil suits. At first there did not seem to be any public prosecutors in criminal cases; but, as the colony progressed, the constables, who at first frequently sat on the jury, began to represent the colony or the crown. ${ }^{40}$ 'The defendant in criminal cases was supposed to be his own attorney, as in civil suits; but delinquents fre-
${ }^{37} \mathrm{C} . \mathrm{IR}$. IV : 618 .
${ }^{30} \mathrm{C} . \mathrm{R}$. VI: 145 , as an example.
${ }^{88}$ B. 'T., Ga., XXII : 90, 176.
${ }^{40} \mathrm{C}$. R. IV : 6 ?. 
quently found voluntary advocates who were willing to aid them partly out of friendship and partly to prevent as far as possible the enforcement of certain laws. ${ }^{41}$

All juries, both grand and petit, were composed of freeholders only. Assistants to the president, pilots, naval officers, and oversecrs of Trust servants were the only classes of persons excused from jury duty. It was not infrequently the case that a jury was hard to secure, for the recorder was often careless in summoning the jury and the jurors were somewhat negligent at first. After the court adopted the policy of fining those guilty of negligence, ${ }^{42}$ conditions improved greatly.

There was some trouble in getting juries to be moved by the evidence instead of by their own prejudices. 'There was a strong sentiment in Savannal against the cnforcement of the rum act; and it was found impossible to convict a violator of the law, however plain the proof against him. ${ }^{43}$ So much trouble was found on this subject that the Trustees authorized the magistrates to try rum cases without a jury, if necessary; ${ }^{44}$ but we have no evidence that this extreme resort was used. In some cases the jury stood as firmly for what they thought to be right as they did in the rum cases for what they kncw to be contrary to law; a notable instance of this was in the Watson case already mentioned.

When a grand jury was sunmoned, it was customary for one of the bailiffs to charge it in a general manner and then to recommend specifically various matters that needed particular attention. Grand juries, like petit ones, were not enthusiastic in punishing some forms of lawlessness. So

\footnotetext{
${ }^{41}$ C. R. IV : 41 .

${ }^{43}$ Ibid., 90-91.

42 Ibid., 71, 100, 484-485.

4t B. T., Ga., IX: Martyn to Stephens, Dec. 5, 1739.
} 
notorious became their conduct in this particular that on one occasion after the bailiff's charge Rev. George Whitefield addressed the jury on the urgent need of stopping the sale of rum and the practice of adultery in Savamah, but even his eloquent appeal was in vain. ${ }^{45}$

Grand juries were at times disposed to go outside the sphere of their duties and to make trouble for the executive officers of the colony by prying into their affairs. In order to accomplish this purpose, the grand juries in 1738 and again in $17+1$ claimed the right to administer general oaths to those summoned before them; that is, they wished to put men on oath to answer any questions asked-not about special crimes or cases under investigation-but about all matters whatever. 'The magistrates vigorously denied that the grand jury had such a right; and it was finally necessary for the 'Trustees to make a clear declaration that the grand juries of Georgia could require oaths only to tell what the deponents knew of a particular crime or crimes. ${ }^{46}$

The Trustees required that courts be held at fixed times and that such times should be well advertised for the convenience of the people. It was customary that the town courts be held quarterly; but adjournments for long or short periods were so frequently made for various causes that as a matter of fact the sittings of the court in Savannah at least were very irregular. Sometimes a court would be held about every six weeks, and again no case might be tried for more than half a year. As a rule the people desired that the courts be held at as long intervals as possible; and on several occasions they petitioned against frequen $t$ courts. ${ }^{* 7}$ No separate times were appointed for meetings of

45. R. IV: 495-496.

${ }^{16}$ C. R. V: 588; C. R. IV Supplement: 186-187.

${ }^{47}$ C. R. IV: 13\%; C. R. IV Supplement: 124. 
the court of general sessions and that of common pleas; but criminal and civil cases were disposed of at the same term of court, and sometimes they alternated on a single day. ${ }^{48}$

In general, the rules and procedure of English courts were followed in Georgia. In a few particulars, the conditions of the new settlement made it necessary to modify the general laws of England. For instance, in selecting a jury for criminal cases, instead of allowing the defendint twenty challenges as in England, the Georgia rules allowed only six; this change was necessary because of the scarcity of jurors in the new settlement. ${ }^{49}$ Again, testimony against a prisoner in criminal cases was allowed by affidavit instead of requiring the witness to face the accused, though it is probable that the practice was only in exceptional eases. ${ }^{50}$ Doubtless there were many other variations from the English customs due to ignorance on the part of the magistrates, but there was slight tendency to introduce changes.

The Trustces expected that reasonable fees would be charged by jailers and by court officials, and frequent instructions were given that tables of these be prepared; but nothing definite appears to have been done in the matter. It is not known whether or not charges were ever made at Savamah; at Frederica no fees were assessed for regular judicial proceedings, though charges were made in a few salvage or prize claim cases. ${ }^{51}$

In this study it is not necessary that a detailed history of the town courts of Savamnah and Frederica, with the personnel of the judges who presided, be given; but a brief résumé of the topic may be worth while. After the 'Trustees

${ }^{45}$ C. R. II: 109, as an example.

${ }^{49}$ C. R. IV: 168-169.

sol Ibid., 90.

¿1 B. 'T., Ga., XXII : 168. 
had constituted courts for the new colony, they immediately selected as first bailiff Peter Gordon, as second bailiff William Watcrland, as third bailiff Thomas Causton, and as recorder 'Thomas Christie. These officials were commissioned by the Common Council on November 7, 1732; but they did not enter upon their duties until July 7, 1733. During the interval between these dates, Oglethorpe himself settled all disputes and punished all offenses without formal judicial action."2 While it was easier for him to do this perhaps than to bother with the regular process of law, yet it was a mistake for him to delay so long in putting the regularly appointed officials to work. It tended to minimize the importance attached by the people to the office of magistrate, and there were already too many influences in that direction, as we have previously noticed.

Little business was done by the court at Savannah during the first few years. Following the custom established during the first months of the settlement, many of the people referred their differences to Oglethorpe for adjudication when he was in the province; but there were so few people in Georgia that at most the legal business was small in volume and in importance.

None of the early appointees of the 'Trustees showed remarkable ability or skill. Peter Gordon the first bailiff seenis to have been a man of no force; and, as we shall notice presently, lis term of service in the colony was short. The second bailiff William Waterland seems not to have served at all, his place being taken by Richard Hodges, who also lived only a short while after his appointment. Thomas Causton, the third bailifi, was the most active and perhaps the ablest of those assuming office during the first year. When Hodges died, Causton was promoted to the position of ${ }^{62}$ Wright's Nemoir 73. 
second bailiff; ${ }^{53}$ and it was only a short while until Gordon returned to England and Causton was appointed first bailiff of Savannah. His enemies aceused him of having used unfair means to get rid of Gordon, and it is probable that he did take advantage of his position to advance his personal interests. As storekeeper for the Trustees, he had great diseretionary powers as to the amount of supplies to be issued to the people of the colony and as to the prices to be charged for these goods. The supplies were the only salary that any of the magistrates received. It was charged that Causton gave to Gordon such meager supplies and at such high prices that the first bailiff was practically starved into a resignation. $^{54}$ Such proceedings were not unknown in Causton's later carcer, and the accusation may have been true in the case of Gordon.

As storekeeper, first bailiff, the Trustees' correspondent, their agent for issuing drafts, and their general agent in the colony, Thomas Causton for about three years exercised almost dictatorial power in the province. We have elsewhere given an estimate of him as an exceutive officer. ${ }^{55}$ When he became first bailiff, he had associated with him Henry Parker and John Dearne. The former was at that time so strongly given to drink that he was frequently unfit for duty; and the latter was nearly seventy years old and crazed in body and mind. After Dearne's death, which soon followed his appointment, Robert Gilbert was seleeted as a bailiff; he could neither read nor write and so he was of little service as a magistrate. ${ }^{56}$ Having such associates, Causton not unnaturally assumed a leading part in judicial

\footnotetext{
${ }^{53}$ C. R. II: 73.

5 True and Hist. Narrative, Ga. Hist. Collec. JI : 201.

B5 Sec Patges 103-164 herein.

s; C. R. II : 233 .
} 
affairs; and for that alone he does not deserve eriticism, but he is open to severe censure for some of the qualities he exhibited as judge. He was vain and overbearing, threatening with corporal punishment those who opposed his will; and his judgment was biased by his friendships and his hatreds. 'That is a serious charge to make against any judge, but the conclusion seems amply supported by the evidence. ${ }^{57}$

Causton seemed to maintain the confidence of the 'Trustees as a judge, and his removal from the office of first bailiff was not for misbchavior in his judicial capacity, but for malfeasance in his executive duties. When he was deposed, Ienry Parker was appointed first bailiff. He had made some improvement in his habits since his earlier appointment as second bailiff, not drinking so much as before; and he made a fairly acceptable judge. He was a man of slight education and of poor business ability; but he was conseientious and fair in his deeisions, and he had good judgment. He beld the position of first bailiff from 1738 to the end of the proprietary control over Georgia, though he almost lost his office soon after he was appointed to it. John Fallowfield, who was the second bailiff at the time, was active in trying to persuade or compel the Trustees to be more liberal in their regulations for Georgia. On the other hand, Thomas Jones, the new storekeeper and the third bailiff, vigorously supported the Trust in all its rules. ${ }^{5 s}$ Parker was inclined to sympathize with the malcontents and showed them so much sympathy that the Trustees determined to depose him; but he changed his views and was restored to favor before the resolution of deposition was carried into exceution. 59

${ }^{57}$ C. R. IV: $27,33,194 ;$ B. 'T., Ga., XXI: Bathurst to Bathurst, Nov. 12, 1737.

${ }^{38}$ Ibid., 476, 482-483, 590.

${ }^{50} \mathrm{C} . \mathrm{R} . \quad \mathrm{V}: 192,242$. 
When the government of Georgia was reorganized in 1741, the three bailiffs of Savannah were made members of the appellate court consisting of the president of the county and four assistants; but no appreciable change was made in the practical administration of justice. There were not enough appeals to the upper court to occupy much time with judicial business, but the bailiffs had a more active part in the executive management of the province. Nor was there any decided change in judicial matters when in 1743 the president and assistants of Savannah county were made the appellate court for the whole province. About 1750 it ceased to be a general rule that a bailiff of Savannah would ex-officio be an assistant in the province; but Parker continued to be both an executive and a judicial officer during the remainder of proprictary rule. The administration of the courts of Savannah encountered few difficulties and created little stir during the last years of the Trust.

The judicial business of Frederiea was of less importance than that of Savannah. Its town court was established in 1735, being patterned in all details after that of the northern part of Georgia. Dr. Thomas Hawkins was the first bailiff and had the most influence in the conduct of judicial proceedings at Frederica, aside from General Oglethorpe. ${ }^{60}$ The latter resided in the southern part of Georgia from 1735 to 1743 , and he exercised an almost determining influence on all important affairs in that section. He was not authorized to exereise any power in judicial matters, but his will prevailed largely on account of his personal prestige and his known interest in the colony's welfare. 'The general results of his influence were good, and the courts at Frederiea moved with less apparent friction than at Savannah, though in secret some of the officials longed for a more active con(1) C. R, II : 125. 
trol of affairs. ${ }^{61}$

When Oglethorpe returned to England in $1 \% 43$ to answer charges preferred against him by one of his officers, Hawkins and Marriott, who were first bailiff and second bailiff respectively, also went to England as witnesses in the case. That left at Frederica only the third bailiff John Calwell. It was only a short time before ('alwell began to make bitter complaints against Major Horton for interfering with civil affairs. Major Horton commanded the regiment in the absence of Oglethorpe; and it is possible that he was somewhat officious in the managenent of affairs at Frederica. He was much abler and more experieneed than Calwell, and he probably was much more capable of deciding what was best than the bailiff, though of course that would not justify him in unlawful interference. The Trustees resented any domination of military power over the civil authorities; and they adopted spirited resolutions on the subject which they requested Oglethorpe to communicate to Major Horton. ${ }^{62}$ They also resolved that no one in military service would be eligible to hold any civil office in Georgia. ${ }^{63}$

As soon as the Common Council learned that there was only one bailiff left at Frederica, it determined to suspend the town court of southern Georgia; and on January 19, 1745 , the surrender of the commissions of all the bailiffs was asked. ${ }^{64}$ This action of the Common Council left the county of Frederica without any judicial machinery except that afforded by conservators of the peace. The town court of Saramilh doubted its authority to try cases from southern Georgia, but finally decided to leave the question to the "True and Hist. Narrative, Ga. Hist. Collec. II: 103-107, 146118.

${ }^{62}$ C. R. I: 460-461.

${ }^{63}$ Ibid., 462-463.

C. R. II : 142-443. 
opinion of some able lawyer from South Carolina. ${ }^{65}$ It was finally agreed that the Savannah court should try important cases, both civil and criminal, in whatever part of the colony they might occur.

No court of large powers was ever re-established at Frederica. The population of both town and county diminished, and the importance of that section of the colony decreased accordingly. By 1748 there was not even a constable in the county, and one was appointed for the special purpose of locating runaway slaves from the other colonies. ${ }^{66}$ In 1749 the authorities at Savannah bitterly complained that Lieut.-Col. Heron, who had succeeded Major Horton as the commander of the regiment, was assuming the civil power in the southern part of Georgia and was opposing the regularly authorized agents of the Trustees in carrying out their judicial work. The extent to which Heron did interfere with the administration of justice cannot be ascertained, but it is highly probable that the reports of his usurpations were exaggerated. ${ }^{67}$

In the foregoing pages attention has been centered principally upon the practical workings of the judicial system at Savannah and at Frederica. These were the only places where fully constituted town courts were established, and it was from these courts that the county and provincial courts developed. We should not leave the subject, however, without giving brief attention to the administration of justice in other parts of the colony. Among the Moravians near Irene, the Salzburghers of Ebenezer, and the Scotch of Darien, nearly all judicial matters were for many years adjusted by a sort of arbitration court composed of various

$$
\begin{aligned}
& { }^{05} \text { C. R. VI : 144-146. } \\
& { }^{80} \text { Ibid., 209-210. } \\
& { }^{87} \text { Ibid., 207-208; 241-242. }
\end{aligned}
$$


religious officials and perhaps others of their brethren. While these adjustments in most cases lacked legal sanction, they were usually satisfactory and greatly decreased litigation. ${ }^{\text {(is }}$ None of the districts mentioned had any courts to which they might resort in Georgia until 17\$1, when the counties of Savamnah and Frederiea were organized. After these outlying settlements were included in the juriscliction of the county courts, they were too far away to receive much bencfit from them. ('onservators of the peace were established in nearly all sections of the provinee, and they were the really active jullicial authorities in all the remote districts of Georgia.

These officers had rery limited powers. They could issue warrants without limit, but all criminal cases of importance and all civil eases involving values above forty shillings would have to be determined in one of the town courts of the province. Suits or causes involving forty shillings or under might be tried by the conservator himself with the assistance and consent of two or three of the principal men of the community. 'The meagerness of the conservator's' power was at times an inconvenience to the people of the colony. For instance, Augusta was one hundred and fifty miles from Savimmah; and a man could not afford to go to the latter place to prosecute suits for a few pounds, such as so many of the Georgia cases involved. Accordingly a petition was filed with the magistrates of Georgia to inerease the power of the justice of the peace at Augusta. ${ }^{69}$ The Georgia authorities hat no power to act on the petition, but they referred it to the 'Irustees with their approval. After some consideration, the Common Council agreed that at Augusta the justice of the peace might try and determine all causes that

is C. R. IV : 394-395, for example.

${ }^{69} \mathrm{C} . \mathrm{R}$. VI: 112-113. 
did not involve a value greater than ten pounds, ${ }^{70}$ but this was a special case, and it did not increase the power of the peace officers in other parts of the province.

In reviewing the whole of the judicial administration under the Trustees, we are impressed with the fact that so large a portion of the business was transacted at Savannah. It would seem that about two-thirds of all the litigation of the province was determined at that place. About half of the remaining business was carried on at Frederica, leaving only a nominal portion of it to be adjusted at other points in the colony. We are impressed also with the fact that most of the cases tried were relatively unimportant. Not many of the civil actions involved large sums, and not a great number of the eriminal prosecutions were capital cases. We may explain this fact on the ground that Georgia was a new settlement having no wealth of consequence, and all business was done on a small scale, so that naturally we would not find large sums involved in disputes that might occur. Moreover, Georgia was settled by colonists who had been carefully picked, and great care was taken to prevent criminals from finding a refuge there, so that heinous crimes were not to be expected in large numbers. In the administration of justice in Georgia, no new principles of law or practice were raised. There were problems and difficulties in abundance, as we have noticed, that seemed to be large when considered one by one in detail; but when we consider them in the light of after years, our impression is that the courts worked smoothly on the whole and that they were probably as efficient as most of those in other provinces. The failures that occurred in administering justice, as we have seen, were largely due to the lack of experience and intelligence on the part of the colonial bailiffs.

70 B. T., Ga., Martyn to Stephens, July 17, 1745. 


\title{
CHAP'TER VIII
}

\author{
THE LAND SYSTEM
}

\section{A. C'harter Prozisions and Early Regulations}

PHE charter granted to the Trustecs for Establishing
the colony of Georgia in America a seven-cighths interest in all that part of South Carolina lying between the most northern part of the Savannah river along the coast to the most southern stream of the Altamaha. 'The boundaries followed the rivers just named to their heads and thence extended westward in direct lines to the South Seas. Included in the grant were a seven-eighths interest in all the islands along the eastern coast to a distance of twenty leagues from the shore and a like interest in all the royal rights of fisheries, mines, and the like. 'The terms of the grant resembled closely those that were commonly inserted in the charters of the early English colonies, except that a full interest in the land could not be granted by the Crown since it did not possess such an interest itself. ${ }^{1}$

The Georgia corporation and its successors forever were

${ }^{1}$ The fact that the Crown possessed only a seven-eighths interest in the lands granted to Georgia ealls for an explanation. The land this granted was a part of that ceded by Charles II in 1660 to the eight proprietors of Carolina. In 1729 the Crown had extinguinhed the claims of seven of the proprictors by purehase, but Lord Carteret declined to part with his interest in Carolina; and the king was therefore unable to grant his eighth interest to the Trust. We shall notice later how the Trustecs secured control of Carteret's interest in Georgia land. 
constituted absolute proprietors of the land, which was to be held "as of our honor of Hampton Court, in our county of Middlesex, in free and common socage, and not in capite," paying therefor yearly the sum of four shillings per hundred acres for all the land that the corporation should grant, but the payments were not to commence until the lands had bcen occupicd for ten years. " The expression "in free and common socage" meant that the tenure by which the Trustees held of the king was to be one of fealty and a definite service, a money payment in this case. The penalty was escheat. The possessors of land in the colony, however, would hold it directly of the Trustees and not of the king. All the lands so granted were organized into an independent and separate province by the name of Georgia, so called in honor of King George II. ${ }^{3}$

The details of granting lands to the settlers were left in the hands of the Common Council of the Trustees, though they were restricted in two important particulars. Under no pretence whatever, might land be granted either to a Trustee or for his benefit either directly or indirectly. Again, the Common Council was forbidden to make any grants at all of more than five hundred acres in the aggregate. The first of these restrictions is easily understood, for it was the constant policy of those who managed Georgia affairs that it would be entirely a philanthropic matter and that their services should be freely given to the enterprise. ${ }^{*}$ The other restriction dealing with the size of grants must be viewed in the light of experience in the various English colonies already settled; and it will be later discussed in that connection.

\footnotetext{
${ }^{2}$ C. R. I : 18.

'Ibid., 19.

'Ibid., g2.
} 
After the 'Trustees had secured their charter and secured in trust Carteret's one-eighth interest in Georgia land, * they undertook to outline a fow fundamental features of a permanent land policy. It was at once agreed that all lands in Georgia should be free, that no profit should be attempted either from the sale or lease of any land in the colony. It was also readily determined that grants should be entailed, and that they should be small in extent. As was common in the proprietary and royal provinces at that time, a quit rent was levied on such lands as might be granted by the Trust.

There were no deinite rules printed to set forth the details of the principles thus adopted; but frequent grants were made to individuals, and these deeds indicate with sufficient clearness the conditions on which the settlers secured their grants. A typical deed would lay down the following regulations under which land might be granted to an applicant: (a) That the grantee be a male twenty-one years or more of age; (b) That he come to Georgia within twelve months and establish a settled abode; (c) That he do not leave Gcorgia within a period of three years without a proper written license; (d) That fifty acres be granted him in tail to his male heirs; (e) That the land be speedily cleared and cultivated; (f) That the grantec plant and preserve one hundred white mulberry trees; (g) That the land could not be aliened, transferred, or assigned without a special license from the Common Council; (h) That the Trust could reenter on any griants concerning which the conditions had not been met within a period of ten years after the grant; (i) 'That a quit rent of four shillings per hundred acres be paid anmually after a lapse of ten years from the time of the grant. 5

* Sec page 250 of this work.

${ }^{8}$ B. 'T., Ga., XII : 4 et seq. 
As these regulations were generally followed in all the earlier deeds to the settlers of Georgia, it is necessary that we examine them briefly. The provision that the land be held in tail male aroused the greatest objection on the part of those who were going to Georgia. This method of inheritance had become antiquated in England, and it had not found favor in any of the older British provinces. The Trustees, however, felt that conditions in Georgia required the regulation. The colony was established as a frontier settlement, and they constantly kept in mind that its purpose was senimilitary. As a result, the Trustees regarded each lot of land as a military fief. The consideration of its grant was not alone the quit rent that would be paid and the personal settlement of the grantee in the colony, but it included also service in actual warfare and constant assistance in performing guard and jury duties. It was felt that tenure in tail general would greatly diminish the military strength of each township; for the female heir who was ummarried would be entitled to a lot and would consequently take from the garrison the portion of a soldier. Women could not serve as soldiers nor sit on juries; and the duties of keeping guard and of serving on the jury would come oftener upon each man, if tenure in tail general were permitted; and, in case of sudden attack by the Spanish or French or Indians, the township might be crippled in making a proper defence. ${ }^{6}$

Objection was also made to the small size of the lots given to each family. The Trustees replied that the amount was fixed at just the quantity that was deemed sufficient for the immediate needs of the settler and his family. Fifty acres were thought sufficient for this purpose, and yet not too much for careful cultivation. It was regarded as very undesirable that any waste or uncultivated land be permitted - A'ccount Showing Progress, C. R. III: 374. 
in a settlement, and the plan of the Trustees was that an industrious man who put fifty acres into good shape might secure more land, while an idler who neglected his grant would not deserve a larger estate. 'To prevent a destruction of this democratic system of equality in landholding through the accumulation of lots in the hands of one man, various rules had to be adopted; and further regulations were necessary to prevent the division of lots into parcels too small to support a soldier-planter and his family. ${ }^{7}$

The tenure in tail male already mentioned would operate to prevent the accumulation or division of lots. Without that tenure, intermarriages might unite several lots into one; or the division of the inheritance among several daughters might reduce each portion to a very few acres. In addition, the Trustees determined not to make their grants in fee simple. If the planters had the right to alienate their lands, as the fee simple tenure would permit, a rapid accumulation of lots in the hands of a few men would be probable; and mortgaging and leasing of lands would result also in further accumulations.

Besides the keeping up of the democratic system of equality in landholding, there were other reasons why the Trustees thought it unwise to grant lands in fee simple to the settlers. The latter were for the most part people who had managed poorly the property they had possessed in England, and it did not seem wise to trust them with an absolute gift of lands in Georgia until by discreet and industrious behavior they had given evidence that they would prove better managers than they had been in the old country.

Again, the inhabitants of Georgia were sent over to secure by their personal residence the lands to be granted

${ }^{7}$ C. R. III : 373.

${ }^{8}$ lbid., 374. 
them, and they voluntarily agreed to reside on their lots and to cultivate the same, before they could get grants from the Trust; so that the Trustees bore the expense of carrying them to the colony, of providing support for them for a year, and of giving them tools, arms and other necessary things. Thus the settlers sold for a valuable consideration their personal residence, their labor, and their industry; and it was not proper, the Trustees thought, to jeopardize the advantages of all this expense by granting such a tenure to the people who would cnable a man to sell his lot and leave the province after having been the object of so much charity.

Besides, the right of the frce sale in the hands of the colonists would likely lead to the introduction of all sorts of people into Georgia. The colonists who went at the expense of the Trustees were carefully selected, and only those were accepted who secined of good character; but, if these people could freely dispose of their grants, the Trustees would have no means of knowing whether the purchasers were proper citizens for the new colony or not. They feared that Catholics might secure a foothold in the colony, and they were also apprehensive lest agents of the Spanish on the south or of the French on the west might be able to settle in Georgia and serve as spies. ${ }^{9}$

Another inconvenience of permitting the tenure of fee simple in the colony, the Trustces argued, would be the overthrow of the letter and intent of the charter which required that not more than five hundred acres of land be granted to any person. They averred that the object of the clause was to prevent there being in the province larger than five hundred acre plantations, and that they might as well grant themselves in the first instance larger amounts of land as

${ }^{9} \mathrm{C}$. R. III: 374-375. 
to permit such regulations as would speedily result in large holdings through free purchase and sale. ${ }^{10}$

The rules of the 'Trustees limiting the size of grants prescribing tenure in tail male, and forbidding the alienation or mortgaging of lots, were the ones that ealled forth the greatest dissatisfaction from the settlers when the colony was first planted. Other rules were found later to be burdensome, but we do not need just here to consider them. The Trustces realized that some of their provisions might work a hardship in special cases, and they arranged to give relief when it was needed. Upon application to the Trustees, a man might secure the privilege of renting, leasing or even of selling his land, if there were cause for it. In like manner, it was agreed that a wife or daughter might be made the heir to a lot upon the presentation of facts showing the need for such an arrangement; and actual relief was granted in several cases.

As we have noticed, the various land regulations were not formally published, and it is not certain that they had been definitely established by any act of the 'Trustees, though the ones outlined above were generally followed during the first two or three years of the settlement of Georgia. In 1735 the Trustees deemed it advisable that their requirements be given definite form, and they were issued under the caption "Rules for 1735." 'There were not many changes made in the regulations under which the colony was already being settled, but a few of these may be noted. It was definitely agreed that all the persons sent at the expense of the Trust would be settled in groups either in towns or in smaller villages, being assigned fifty acres each for their support. ${ }^{11}$

While the same rules as to tenure in tail male were speci1". C. R. III: 375 ,

11 Voyage to Georgia, Ga. Hist. Collec. I: 80-84. 
fied and while it was stated that the lands should revert to the Trust in case of the failure of male heirs, the Trustees asserted that they would have "a special Regard to the Daughters of Freeholders who have made improvements on their Lots," if these danghters were not provided for by marriage to some one already possessing land. The provisions meant that the Trustees would grant the improved lot to the husband of such a daughter if he did not have one, or that they would recompense the daughter or daughters for the improrements made and would then grant the land to some one else.

The rule against the leasing, renting, or alienating land was also maintained; but it was permitted that the wives of freeholders who survived their husbands should be entitled during their lives to the house and to one-half of the improved lands held by their husbands. At the death of a wife thus holding a life estate, the whole property would revert to the Trust.

It was thought necessary to be somewhat explicit about the cultivation of lands within a definite period; and it was required that if any part of a grant were not cultivated, planted, cleared, improved, or enclosed by a worm fence six feet high within ten years after the grant was made, such a part would belong to the Trust and the grant as to that part would be forfeited. ${ }^{12}$

So far as we can ascertain, it was also in 1735 that the first full statement was made public as to the conditions upon which land would be granted in Georgia to adventurers going at their own expense. The rules were prepared on the assumption that each adventurer would take to the colony ten able-bodied white men as servants, but it was not requisite that so many be taken. To a person taking over ${ }^{12}$ Account Showing Progress, C. R. III: 410. 
the full ten servants, a grant of five hundred acres would be made, and smaller concessions were made to those taking over fewer servants.

It was required of such adventurers that they go to the provinee and enter upon the task of improving their grants within twelve months after the deeds were made. 'They must register their grants within one month after they were issued; and they must abide in Georgia three years after their grants were registered unless they were duly licensed to leave. Within ten years after his grant was issued, each adventurer was required to cultivate or improve one-fifth of the land given to him, and he was also required to plant and duly cultivate a thousand mulberry plants on each hundred acres of land to be cleared, the Trustees undertaking to furnish the plants.

The same regulations as to tenure in tail male, fencing the property, leasing or alienating the estates, the privileges of danghters and widows, and reversion to the Trustees, were made for the grants to gentleman adventurers as applied to those who were beneficiaries of the 'Trust. ${ }^{13}$ In addition, it was specifically provided that no adventurer could form a partnership to make potash though it was allowable for any one to manufacture it individually. ${ }^{14}$

We have already noticed that the Trustees were disposed to prevent if possible any undue hardship which their rules might work in individual cases. They always relented when they found that suffering would be the result of carrying

${ }^{13}$ Voyage to Georgia, Ga. Hist. Collec. I: 80-84.

${ }^{1+}$ This rather curious provision was due to the fact that the 'Trustees had granted for a period of years all the privileges of making potash in Georgia throngh companies or partnerships to a company of twelve men. This group did not fulfill the conditions of their grant and nover began operations, but they were expecting to do so when the "liules of 1735" were issued. 
out the letter of a law. For instance, the rule was that lands granted to a man were to revert to the Trust in case of a failure of male issue, but the Trustees regularly gave to the female heirs or to the nearest relatives the value of whatever improvements had been made by the deceased. The general result of the whole policy pursued was that the regulations were not particularly burdensome in fact; but people read the letter of the rules without knowing the spirit in which they were executed, and many were deterred from going to Georgia on account of the severity of the requirements. The growtl of the colony was unquestionably delayed in this way.

\section{B. The Struggle for Better Land Regulations}

The people of Georgia from the beginning had felt the land laws under which they lived to be a burden, and they appeared restive from time to time on the subject. By 1738 the dissatisfaction was becoming so manifest that the Secretary of the Trustees William Stephens began to refer frequently to the situation in his letters and journals which were sent to the Trustecs. Some of the leading men in the colony were threatening to leave if some relief were not granted, for they claimed that they could not get credit with business men outside of the colony so long as they were not able to show fee simple estates. ${ }^{15}$ The Scotch who lived at Darien protested in a body against the tenures, and a universal defection among them seemed imminent. ${ }^{16}$

The dissatisfaction which had been more or less smothered for some years developed toward the close of 1738 into a formal complaint and petition to the Trustees. 'This

$$
\begin{aligned}
& { }^{15} \text { C. R. IV : 11, 15, } 29 . \\
& { }^{16} \text { Ibid., } 239 .
\end{aligned}
$$


document was signed by one hundred and nineteen frecholders of the Savammah region. 'The petition set forth the need of fee simple tenure for their land, asserting that this would result in the coming to Georgia of many settlers from the other colonies and would encourage those already in the province to try to repair their shattered fortunes and make provision for posterity. The petition also sought the use of negro slaves in Georgia. 'The latter part of the representation was opposed by the people of Darien and Ebenezer; and it attracted so much attention that the question of land tenures, though put first in the petition, was overshadowed in importance. The Trustees indignantly rejected both items of the petition and severely rebuked those magistrates who had taken the lead in formulating and circulating the petition. ${ }^{17}$ 'There ean be little doubt that the attitude of the industrious Salzburghers and Scoteh made the Trustees feel that they were entirely right in rejecting the portion of the petition that related to slavery; and, as has been mentioned, they did not differentiate with eare between the parts of the representation. Seventy-five of the landholders of Savannah did not sign the paper: eighteen of the Scotch, and fifty-one of the Salzburghers, protested against the slavery portion of the petition. From the province as a whole, there were apparently others who were either indifferent to the project or actually opposed the matter; and it is not surprising to find that the Trustees opposed the general policy of changing the existing laws, ${ }^{1 s}$ though they had already modified them to some extent and continued to do so almost every year. In their reply to the Georgia petition the Trustees appealed to the verdict of posterity as to whether they or the petitioners were the best friends of the

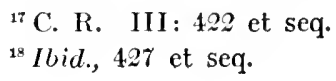


colony. There can be no doubt that the Trustees had less of selfishness in their service of Georgia than had the malcontents of the province, and they were endeavoring to be disinterested friends of the colony; but candor compels one to admit that the representation of the residents of Savannah set forth a wiser policy than that pursued by the Trustees.

One of the earliest modifications of the land laws was passed by the Trust in the beginning of 1739 before the petition just mentioned had reached England. The Trustees were moved to the action by the reports of dissatisfaction that Secretary Stephens had sent so frequently, and they felt that conditions had changed considerably since the first establishment of the colony. The province was making fair progress; the population had increased; and the presence of a regiment made the matter of defence less pressing than when the colony was first established. There seemed no good reason why some concessions should not be made. Accordingly at the anniversary meeting of 1739 , it was enacted that in defailt of male issue the legal possessor of land might by deed, will, or testament appoint his daughter or any other male or female relative to inherit his lot; but the inheritance would be entailed to the male heirs of such a successor, and the heir so appointed must claim his inheritance in a court of Georgia within eighteen months after the death of the testator. The regulation was shortly broadened so that the owner of land might appoint any person whatever, whether a relation or not, to succeed him in his inheritance. $^{19}$

Shortly after these concessions were adopted, the Trustees received the representation from Georgia; and, as we have seen, they rejected it emphatically. We should expect ${ }^{19}$ C. R. III : 394 . 
that this would end their concessions to the colony on this subject; but that was not the case. 'The representation was so promptly refused because the 'Trustees thought that it was the product of idle and undesirable inhabitants of Savamnah. They were always ready to satisfy if possible the industrious people of Georgia; and within two weeks after they refused to make the alterations desired in the petition, they drew up a statement of changes in the land system that they proposed to adopt. These changes were prepared by July 11, 1\%39; but they were not finally put into an acceptable legal form until the next September. The changes were designed to benefit only those who held eighty or more acres of land. They regulated the disposal of lands of one dying without male issue, particularly securing the rights of widows and daughters of such tenants. These concessions practically abolished forfeiture of lands for failure of issue; because they specified that when male issue failed the lands should descend to the daughters of the owner; and, in case of a failure of any issue whatever, the property would descend to the heirs at law unless the owner should devise to some one else. It was provided, however, that no one could thus secure lands whose lroldings would be thereby increased to more than five hundred acres. IVidows were guaranteed all the rights which they would possess in England. All persons who wished to take advantage of these concessions were required to enter their claims to land in the courts of the colony where the proper papers would be issued to them without cost to the landholders. 'The regulations were printed for distribution among the settlers; and advertisements of their terms were inserted in the London and South Carolina papers. So much publicity was given to the changes because the Trustees felt that the restricted tenures were seriously handicapping the colony. It was ear- 
nestly debated among the Trustees whether the changes made were not suficiently important to be enacted as a formal law with the approval of the king in council; but this was deemed unnecessary by a majority of the corporation. ${ }^{20}$

Though both the Trustees and the people evidently regarded these changes just noted as important, it seems to us that they could not greatly affect the landholding in Georgia. They applied only to persons holding over eighty acres, and there were few such colonists in the province. Again the changes applied only to those who died without issue. Besides, the actual details of the new law merely stated what had been in actual practice all the while, though of course the publication of the purpose of the Trustees would give the people more assurance of leniency than the mere practice without legal endorsement. It seems to us that the main significance of the regulations is that they evidence a disposition on the part of the Trustees to make the land laws easier for the settlers. What they actually granted was of slight importance in comparison with the fact that they yielded to the colonists; and we shall find that gradually they gave way on point after point until the wishes of the settlers were fully realized on this subject.

On the 7th and on the 21st of July, 1740, the Trustees again determined to remove all reasonable grounds of dissatisfaction with the land system of Georgia. After consultation with one of the leading settlers of the colony who appeared to know the conditions in the province, they adopted several interesting changes which were of more practical value than the much vaunted rules of the preceding year. One of the most notable changes dealt with the size of plantations that might be held in Georgia. The clause

${ }^{20}$ B. T., Ga., IX: Verelst to Stephens, Aug. 10, 1739; C. R. V: $210-212,216-217,225$. 
in the charter forbidding the 'Trustees to grant more than five hundred acles to any person had constantly been interpreted to mean that no person in the eolony could hold more than five hundred acres by whaterer means obtained. The clause was in $1 \% 40$ construed more liberally. It was agreed that a daughter or any other person might be capable of holding by devise or inheritance any quantity of lands which did not increase her or his possessions to more than two thousand acres. ${ }^{1}$ 'This action naturally did not result in very large plantations; for even the two thousand acre linit could be reached only very slowly when the only means of increase beyond five hundred acres must be by the single method of inheritance. There was as yet no general privilege of purchase or sale, and yet the concession was valuable because it pointed once more to greater leniency in the future.

At the same time, the privilege was granted to Georgians for the period of two years of making leases for any term not exceeding five years of the whole or of a part of their estates, provided the lessee or lessees continue resiecent on the lands during the term of the lease. ${ }^{22}$

As a means of making the inhabitants perfectly content, as they thought, the 'Trustees made much easier the requirements for cultivating land and planting white mulbery trees. Up to this time, the possessor of five hundred acres was required to cultivate or improve two humbled acres of his grant within ten years; this amount was reduced to sixty acres. Those who held five hundred acre grants were required to plant two thousand white mulberry plants within the first decade after their grants: this number was reduced by one-half. Similar reductions were made for those

${ }^{21}$ C. R. II : 338; C. R. V: 385.

${ }^{22}$ Ibid., 340-341. 
who held smaller quantities of land. The Trustees felt that the sum total of the results of their new policy ought to be satisfaction on the part of all the colonists and the preventing of further forfeitures of lands. ${ }^{23}$

In the spring of $1 \% 41$, the liberal spirit of the Trustees was further shown in still greater concessions in the making of leases and in the cultivation of land. The term of five years, for which leases had hitherto been permitted, was too short to encourage tenants to make improvements; and, when this fact was brought to the attention of the Trustecs, they agreed that for a period of three years landholders in Georgia might have the privilege of leasing their lands for a period of twenty-one years or less, provided that the lessces reside in person on the property. Also, instead of requiring sixty acres of land to be cultivated within ten years for every five hundred acres granted, the amount was fixed at fifty acres, with a corresponding decrease in farms of smaller acreage. ${ }^{2+}$

As we have just noticed, the land laws had been slightly altered from time to time without being definitely revised, and great confusion resulted. Besides, some of the regulations were not well understood, especially those of September, 1739, about which one of the colonists is said to have remarked that the whole laws consisted of "tails" and "males," and that all the lawycrs in London could not make them plain to a common man. Accordingly the Common Council agreed to incorporate into one law the various changes and alterations that had been made. On March 8,1742 , the draft of the new law was reported and agreed to. There were no essential changes in the various details which we have already noted. It was ordered that all future

${ }^{23}$ C. R. V: 385.

$\because$ B. T., Ga., XII : 462 et seq. 
grants slould have attached to them a printed eopy of the conditions provided in the new eomprehensive regulations. ${ }^{25}$

It is to be particularly noted that while the Trustees had made many concessions to the colonists yet they had refused to yicld on the two points of which the Georgians most complained. Lands were still held in tail male, with some minor exeeptions; and there was still lacking the right of free purchase and sale of estates in the province. Accordingly when Thomas Stephens petitioned the House of Commons in behalf of the people of Georgia on April 30, 1742, one of the main objects he sought was the fee simple tenure of landholding. In addition he petitioned for lower quit rents and for the use of negro slaves. In the debates that followed in the House on the subject, there was a strong sentiment in favor of giving the fee simple tenure at least to those persons who went to settle in the colony at their expense, and there was also a sentiment in favor of lower quit rents; but it was deemed best to leave these matters for the 'Trustees themselves to adjust; and so the only item of the petition of Stephens that was openly approved by the House of Commons was the importation of rum, as already noticed. ${ }^{26}$

'The Trustees, taking into consideration the sentiment of the House as expressed in the debates on Georgia matters, determined to grant lands in fee to those who should go to the colony at their own expense, but they were unwilling to make the grants except under certain conditions. Oneeighth of the land granted must be improved within ten years, and the land must not be alienated until the expiration of ten years. It was further stipulated that no person could hold more than two thousand acres of land; if

$$
\begin{aligned}
& { }^{25} \mathrm{C} . \mathrm{R} . \quad \text { II }: 393-10 I . \\
& { }^{26} \mathrm{C} . \mathrm{R} . \mathrm{V}: 636 .
\end{aligned}
$$


a man through inheritance became entitled to more than that amount of land, he would be permitted to sell the excess above the two thousand acres, subject to all the conditions of cultivation. ${ }^{2 \tau} \mathrm{A}$ formal law was prepared incorporating these various regulations in regard to the tenure of adventurers, but the law retained the old rules regarding the land tenures of charity colonists. The act was referred to the king in council for approval, but it was not acceptable to the law officers of the crown on the ground that it provided two tenures for one province and that this was not advisable. The matter was referred on December 5, 17t3, to a committee, with whom the whole affair was permitted to die, so far as the records show. ${ }^{28}$ For seven years more the objectionable tenures were continued, and the colony suffered accordingly.

At length on March 19, 1750, a resolution was adopted by the Common Council enlarging all grants that had been made to absolute inheritances and determining that all future grants would be by the same tenure to the grantees, their heirs, and their assigns. ${ }^{29}$ This was at last the tenure for which the people of the colony had struggled during the eighteen years preceding. The lands were no longer entailed; and they were not burdened by restrictions as to purchase and sale, though nothing seems to have been done to permit larger grants than those before allowed. In the March regulations, no mention was made of any requirements as to clearing and planting the land or as to cultivating mulberry trees; but in August of the same year in the so-called "Negro Act," the Trustees inserted the require-

\footnotetext{
${ }^{27}$ 13. T., Ga., X: Martyn to Oglethorpe, Aug. 10, 1742.

${ }^{24}$ B. T., Ga., XIII: 68 et seq.; C. R. V: $710-711$.

${ }^{29}$ B. 'T., Ga., XI: Martyn to Pres. and Assts., May 3, 1750; C. R.
} II $: 500$. 
ment that all planters who employed negroes must plant mulberry trees in proportion to the land they held. ${ }^{30}$ This was not, however, so much a regulation affecting landholding as affecting the use of negroes.

There was great rejoieing in the province over the concessions made; and a spirit of confidence in the future of the colony was at once engendered. Colonists from the other British provinces began to come to Georgia, and the whole outlook of the colony began to improve so far as conditions in America were concerned. It was not wholly the changes in the land system that brought about the improvements mentioned; but they contributed as much as any other one canse to this end.

\section{Forfeitures}

In considering the forcgoing summary of the rules and laws which the 'Trustees formulated for the land system of Georgia, it will be immediately noted that oceasions of forfeiting estates in the colony were very numerous. Indeed, to sum up the matter briefly, there were nine distinet grounds on which the Trustees at first reserved the right to re-enter and take possession of the grant made to any settler. These various occasions of forfeiture were: (1) Failure to pay within twelve months after it became due a quit rent of four shillings per hundred acres; (2) Neglect to build within eighteen months a house at least twenty-four feet in length, sixteen feet in width, and eight feet in height; (3) Leaving the provinee within three years after the grant unless a proper license was secured for being absent; (4) Failure to clear and eultivate within ten vears one-fifth of the land possessed: (5) Neglect to plant and properly care for ten ${ }^{80}$ C. R. I: 60. 
white mulberry plants for each acre of land cleared; (6) Any attempt to alien or transfer a lot without the proper permission of the 'Trustees; ( 7 ) 'The committing of a felony; (8) The employment of any negro or other slave without a special license; (9) The failure of male issue. ${ }^{31}$

It has been previously stated that the land regulations were not strictly enforced. If they had been rigorously applied, practically every lot and estate in Georgia would have escheated to the Trustees; for almost no settler fully met the requirements of his grant. The Trustees showed a decided tendency to waive forfeitures in individual instances, and later to make general releases of forfeitures. The reasons which led to this action on their part will be briefly noted.

The clause requiring a man to make a prompt payment of his quit rent did not become operative until ten years after he took possession of his land; and so many changes in the rules and regulations for holding land were made before 1743 , when the first quit rents would become due, that the whole subject will be given fuller treatment in a separate section of this chapter.

The law for building a house of specified dimensions within a definite time gave comparatively little trouble. The work of construction was carried on in the first settlement, and in some of the later ones also, by means of joint labor; and this was generally the course followed by settlers sent at the expense of the Trust, who composed a very large percentage of the colonists. Where this plan of work was adopted, it was obviously impossible to penalize an individual for failure to have his house completed, since his time would have been occupied in theory at least in assisting his neighbors and in helping to ereet public buildings. The ${ }^{s 1}$ B. 'T., Gia., XII : 4 et seq. 
settlers who went at their own expense were generally located away from the towns, and buildings on their own lots were necessary. As a matter of fact, more time seems to have been given to building than was advisable from a business standpoint; and we find no record of any forfeiture on account of this clause of the grants. ${ }^{32}$

There were abundant opportunities for the Trustees to re-enter upon grants because the grantees left the province without permission. It was a point about which the Trust was somewhat concerned, especially as to those sent at its own expense; for after it had paid the cost of sending a colonist to Georgia and of supporting him for a year, it very naturally would not like for him to move to Carolina or to return to England and still retain possession of his land in the colony. Occasionally the Trustees would declare vacant the grant to such a person without any remedy; but more often they conferred if possible with the absentee and attempted to persuade him to return to the province. If he would consent to take up again his residence in Georgia, his forfeiture would be released; otherwise it would be enforced. ${ }^{33}$

A difficult problem that faced the Trustees toward the latter part of their adninistration was whether or not lots ought to be forfeited for absence from the colony when the owners had remained the required time after receiving their grants. During the Spanish wars, many Georgians had left the province in search of less dangerous homes. They were not allowed by law to sell their estates, and they simply abandoned them. The President and Assistants in Georgia did not know what to do with such lots and they referred the matter to the Trustees. So far as we can learn, the

${ }^{32}$ B. T., Ga., XXI: Stephens to Verelst, July $25,1738$.

${ }^{\text {s3 }}$ C. R. I: 292 ; C. R. II: 96. 
question was still unsettled when Georgia was surrendered; but the tendency was for a lenient treatment of all those who had showed any interest in the colony. ${ }^{34}$

The most general grounds for forfeiting lots in Georgia were two that we may consider jointly; namely, the failure to cultivate the requisite acres of land and the neglect to plant and keep in condition a sufficient number of white mulberry trees. In their requirements on these points, the Trustees showed that they did not understand the difficulties of establishing a colony under the conditions that prevailed in the province of Georgia. Clearing and cultivating land in a heavily wooded country like the new colony was no easy task under most advantageous circumstances; and in Georgia the limitations of the labor supply and the hostilities with the Spanish in Florida aggravated the natural hardships in carrying out the conditions of land grants. Though the Trustees were perhaps too exacting in fixing their stipulations, they showed a readiness to pardon the failure to fulfill them; and, while they made heroic efforts to get the colonists to cultivate their land and to plant mulberry trees, they do not appear to have forced the forfeiture of estates on these grounds only.

Since the land in Georgia was free, and since the Trustees were usually willing to license sales and exchanges upon a proper application to them, there seem to have been only a few violations of the rules forbidding the free purchase or sale. In the cases reported, the Trustees were prompt to act, enforcing their authority and checking any attempts either to accumulate tor much land or to encumber or alienate rashly what one possessed. ${ }^{35}$

3* B. 'T., Ga., XXIV: 32.

${ }^{35}$ C. R. II: 263-265; B. T., Ga., VIII: Martyn to Dobree, May 29, 1735. 
So far as we can tell, the question of forfeitures did not arise on account of felonies conmitted; and there was practically no agitation of the subject on account of the employment of negroes, though the latter question stirred up bitter wrangling in the colony in many other respects.

The last of the occasions for forfeiture which we shall notice was for the failure of male issue. We have already noted that this regulation was speedily modified in favor of the colonists; but, while it was in force, it was not allowed to work a hardship on the settlers. Although the lots of those who died without male heirs were declared escheated to the 'Trustees, yet the value of all improvements was given to the heirs at law, so that no real injury was worked. ${ }^{30}$

One reason why there were not more forfeitures for the particular reasons noted above was that the 'Trustees from time to time issued a general release of forfeitures. These releases excused from penalty all violations of the land regulations up to the time the releases were issued. The first action of this sort on the part of the 'Trustees eame in $1 \%+0$. It was in the nature of a repeal of a resolution passed the preceding year. By this resolution of 1739 the Trustees had determined to instruct the magistrates in Georgia to occupy all forfeited estates and grant them anew to applicants for land. On $J_{u l y} 7,1 \%$, this action was repealed, and it was enacted that no breach of the covenants regarding land prior to June 24,1740 , would cause a forfeiture of the grant. ${ }^{37}$

Early in 1741, a similar resolution was adopted providing a general release of all forfeitures on any account whatever to Christmas $1740 .^{38}$

${ }^{3 n} \mathrm{C} . \mathrm{R}$. II : 8\%.

${ }^{37}$ B. T., Ga., XII : 418 et seq.

s. R. II : 354 . 
The third release, which was adopted on July 13, 1750, was a sort of corollary of the act providing for tenures in absolute inheritance. Since his tenure was to apply both to grants that had been made and to those that would be made in the future, it was necessary that some act be adopted to indicate that the former conditions would not be binding; hence this release was issued. ${ }^{39}$

To sum up the conclusions on this topic, the Trustees enforced relatively very few forfeitures of land, certainly not enough to cause any great dissatisfaction among the colonists; but they did have a formidable set of regulations under which they might escheat the lands they had granted. It was not so much what they did as dread of what they might do that caused alarm and uneasiness among the settlers. There were annoying trifles also that irritated the colonists; such, for instance, as appearing in court and filing elaims whenever they wished to obtain the benefit of minor land changes that were made from time to time. ${ }^{40}$ in the light of the results that followed the policy of the Trustees, it appears now that it would have been wiser for them to give the colonists more freedom in their activities rather than by threatened forfeitures to try to force them to perform their duties.

\section{Quit Rents}

The charter provided that the Trustees pay annually to the king four shillings per hundred acres of land in Georgia which they might grant to settlers, said payment not to commence until after ten years from the time of the grant, and it was to be paid in proclamation money of South Caro-

${ }^{2}$ B. 'T., Ga., XIII: 161.

${ }^{40}$ C. R. IV: 63ə, for example. 
lina. When Lord Carteret in 1733 ceded his interest in Georgia lands to the Trustees, it was agreed that he should receive six pence per hundred acres for all the land that might be granted for settlement. None of the records make the point clear as to whether this six pence was to be levied in addition to the four shillings due the king or whether it was to be deducted from his rent. The latter view seems more probable. ${ }^{41}$

In making their grants to the poor settlers of the colony, the Trustees did not attempt to make any profit for the 'Trust. 'They specified that each holder of fifty acres should be required to pay two shillings ammually for his grant. This payment was to be made in advance and was to be paid in sterling money, which was the standard money in all transactions of proprictary Georgia. The Trustees could make their payments to the king and to Carteret in proclamation money, as we have already noted. Since the latter bore to sterling money the ratio of three to four in value, the charge made to the colonists in proclamation currency would be at the rate of fire shillings four pence per hundred acres. ${ }^{42}$ This overcharge in quit rents would afford only a safe margin for the 'Trustees to make allowance for rents which they might not collect, their payments to the king and Carteret being fixed by the number of acres granted without regard to amount of rent that the Trustees could collect. No rent was charged by the Trustees until the end of the tenth year after the grants were made.

In making early grants to adventurers who paid their own expenses, the Common Council did not adopt any fixed rule as to what quit rent should be charged, nor did they adopt the ten year period of free rent as in the case of the set${ }^{41} \mathrm{C} . \mathrm{R}, \mathrm{V}: 675$.

"Statutes at Large, VI Anne, Chap. 30; B. T., Ga., XII : 4 et seq. 
tlers sent by the Trust. 'The adventurers paid a consideration of one pound one shilling sterling for making each grant, while charity settlers did not have this fee to pay. The first two grants to independent colonists provided that the rent should begin at the end of the seventh year and was to be at the rate of five shillings sterling until the end of the tenth year, after which time it was to be at the rate of ten shillings for cach hundred acres. ${ }^{43}$ Only a few deeds with these terms seem to have been issued. The next group of deeds made no provision for rent until the expiration of ten years, but the annual amount was fixed at ten shillings per hundred acres. ${ }^{44}$ By the summer of 1733, the Trustees had doubled the already high rents, requiring those going at their own expense to pay twenty shillings for each hundred acres. The "Rules of 1735" adopted this rate as permanent, and it continued to be the usual charge during the remainder of the proprietary period. ${ }^{45}$

Twenty shillings sterling was unquestionably a very high rate of rent in comparison with the amounts charged in other colonies. For instance, in Pennsylvania during the same period, the quit rent was only a half penny sterling per acre, a little more than one-fifth of the Gcorgia rate, though it is only fair to note that Pennsylvania charged a purchase price that exceeded somewhat the Georgia fees. ${ }^{46}$ In Maryland, when Georgia was first settled, the rent was ten shillings; but five years later it was reduced to four shillings, with a rather reasonable purehase price. ${ }^{47}$ In South Carolina the rates seem to have varied from twelve pence per hundred acres to one penny per acre, but in either event

${ }^{* 3}$ B. 'T., Ga., XII : 31-45.

"I Ibirl, 46 et seq.

"5 Ibid., 100 et seq.; Account Showing Progress, C. R. III : 412.

* Shepherd-History of Proprietary Govt. of Penn. 34.

${ }^{47}$ Mereness-MId. as a Proprietary Province 85. 
the rent was much lower than that in Georgia for those going at their own expense. ${ }^{\text {ts }}$ It is to be further noted by way of comparison that the lands in most of the colonies just cited were superior to what the adventurers secured in Georgia, though this was not always the ease.

As the time approached when the payments from the Trustees to the king and c'arteret would fall due, the managers of Georgia affairs felt constrained to petition for relief in payments on lands of the poorer quality. Much of the soil around Savanab had been found very unsatisfactory for agriculture, being termed "pine barrens." If the 'Trustees got relief in the matter, they proposed to give to the colonists the benefit of the concession. On December 5, 1741, a committee was appointed to draft the petition; but nothing further seems to have been done in the matter. ${ }^{49}$

Probably the reason why the committee let the matter drop was that the subject of quit rents, along with many other questions relating to the colony, soon came up for consideration in the House of Commons on the petition of Thomas Stephens as agent for at least a portion of the inhabitants of the provinee. The petition of Stephens as to quit rents was that they be reduced at least as low as those that usually prevailed in the other colonies of America. During the debates in the House, it developed that a large number of the members thought that the quit rent for adventurers should be reduced to three shillings per hundred acres; and a resolution to that effect was introduced. This was withdrawn, however, and no official action was taken in the House of Commons, the 'Trustees being left to seek such relief from the king as might enable them to make the suggested change in the rates." 50 'This was a most hopeful situa${ }^{4}$ Smith-S. C. as a Royal Province 30.
"C. R. V: 576 .
${ }^{50}$ Ibid., 640. 
tion for the independent settlers of Georgia; for a reduction in rent from twenty shillings to three shillings on each hundred acres would be a material eneouragement for more adventurers to settle in the colony.

On July 15, 1742, the Trustees drew up a petition to the king setting forth that the quit rents in Georgia which had been postponed for ten years would soon be falling due; and that in a recent examination before the House of Commons it appeared that further encouragements were needed for Georgia. The petition then prayed that the quit rents might be released to the Trustees in order that they might reciuce the same for the inhabitants of the colony and use the remainder for the benefit of the province. ${ }^{51}$ There was considerable hope that the petition might be favorably received and that a possible source of ineome might be afforded the Trust, besides their being enabled to reduce the rents. On November 22, 1742, the report of the Board of Trade was announced to the Trustees. The report approved some encouragement to the provinee, but it did not recommend an entire release of the quit rents to the Trustces. The suggestion made was that the rental of the king should be so reduced that the Trustees would have to pay only two shillings instead of four per hundred acres. ${ }^{52}$

An act was then prepared by the Trustees reducing the quit rents of all classes of settlers in Georgia from four shillings to two shillings, whereof eighteen pence would go to the king and six pence to Lord Carteret. ${ }^{53}$ Instead of issuing a general order to this effect, as the Trustees had power to do, they incorporated these details in a general act changing the tenures in the province; and, as we have

\footnotetext{
51 C. R. $V^{y}: 651$.

${ }^{53}$ Ibid., 6r0; C. R. I: 408-411.

${ }^{53}$ C. R. $V^{r}: 675$.
} 
noticed, the whole act was disapproved because it provided two kinds of tenure for one colony. While the Board of Trade was willing to approve the portion of the act relative to quit rents, it failed to pass the king's approval because incorporated with objectionable clauses; and the reduction which the Trustees proposed to make was never realized. The 'Trustees themselves seem not to have gotten any reduction from the king, the disapproval of their land act apparently putting a stop to all negotiations for reductions. Whether the failure to perserere in the matter and to so alter the land law as to make it acceptable to the Board of Trade was due to resentment toward the Board or to mere apathy and indifference on the part of the Trustees is not apparent; but certainly they lost an excellent opportunity to aid the colony and to silence complaints.

Since the time was actually at hand for the quit rents to be paid, the Trustees waited upon Lord Carteret to ask that he appoint a collector to receive his portion of the rents; but he declined to do so, saying that he would not hold the 'Trustees responsible for more of his rents than they might actually collect. ${ }^{54}$ As a matter of fact, it was only a short time until the king purchased all Carteret's claims to land in Georgia and in the Carolinas; and his interest in the quit rents of the province ceased after $1 \% 4+5$

On May 23, 1745, the Common Council determined to begin the collection of such rents as were then due. It was ordered that a list be prepared of all grants on which the rents had become due, and the magistrates were directed to appoint a proper person to collect the money. ${ }^{50}$ The

${ }^{4} \mathrm{C} . \mathrm{R} . \mathrm{V}: 675-676$.

${ }^{\circ}$ B. 'T., Ga., XIII: 73 et seq.; N. C. Colonial Records IV: 655 et sey.

"C. IR. II : 119. 
determining of what was due on the various grants was put into the hands of the president of the colony; but he was so old and infirm that a very unsatisfactory return was made to the Trustees, and they ordered that the work be done anew. About the same time the auditor-general of the plantations called upon the 'Trustees for a report as to the money that had been paid to the king in quit rents. As a matter of fact, nothing had been paid by the 'Trustees; but they excused their tardiness by explaining the difficulty of getting from the colony an accurate report of the land griunts that hatd been oecupied. ${ }^{5 i}$

Repeated efforts were made to get a satisfactory rent roll completed; but the matter had become very complicated. The releases from forfeiture, which were made occasionally, further complicated the affair; for it was not clear whether or not these releases cancelled the rents that had become due. Nothing really effective was accomplished before the Trustees felt compelled to surrender their charter. Among the recommendations that they urged in making the surrender was, "That the Arrears of Quit Rents, due at this time, be remitted, since Most of the Inhabitants have been prevented by the War, and the various Obstacles that always occur at the first Settling of a Colony, from Cultivating so much of their Lands as it might be expected They wonld; And that the Quit Rents for the future be reduced from four to two Shillings for Each hundred Acres, this last Sum being as much as is usually reserved in any of his Majesty's Provinces in America." 58 Among other considerations that induced them to make this suggestion, was a petition from the Assembly that met in Georgia in 1751 urging that the Trustees apply for a reduction in the

${ }^{5 i} \mathrm{C} . \mathrm{R}, \mathrm{I}: 503-504$.

${ }^{8}$ Ibid., 5 ro. 
rents. 59 The recommendation of the 'Trust to the Board of Trade made no distinction in rents for those sent as charity settlers and for those who were adventurers; but it was evidently intended to apply to all holders of land in the province.

No money was ever collected for quit rents in proprietary Georgia by the Trustees, by the king, or by Carteret. It was generally conceded by all concerned that the colony was not sufficiently prosperous for it to be fair that the rents be enforced. Conditions greatly improved during the last two or three years of proprietary control; and it is quite probable if the Trustees had remained in power a few years longer that the quit rents would have been regularly and successfully collected. We have noticed that the rent rolls were confused. This was not due to carelessness on the part of the 'Trustees, for they had arranged that accurate records be kept not only of original grants but also of all changes in the ownership of lots. Incompetent officials in the province were largely responsible for the confusion that occurred; but at worst the Georgia records were superior to most of those kept in other English provinces; and they could have been arranged for the collection of rent, if the poverty of the colony had permitted it.

\section{E. The Machinery of the Land System}

Since the Common Council of the Trustees had exclusive power to make grants of land and to prescribe the terms of each grant, all lands were conveyed either directly or indirectly by this body. As in all other matters concerning the management of the provinee, the Conncil showed a decided disposition to superintend in person the details of the ${ }^{50}$ C. R. I : 559 . 
work. Great care was exercised to perform the duty accurately and to avoid every suggestion of fraud.

At the outset, two methods of procedure were adopted, one for making fifty acre grants to persons going at the expense of the Trust and another for providing for those who should go at their own expense. It would be manifestly difficult to make a large number of small grants at a distance of three thousand miles from the land to be ceded, if each grant had to be treated separately and its land specifically described; and consequently the responsibility of making these small grants was in part delegated by the Council. When the first settlement was planned, a trust deed for several thousand acres was granted to three of the colonists who were instructed to draw deeds for fifty acres each to all the heads of families sent at the expense of the Trustecs, if such persons should make application for the land. These grantees under the trust deed had no authority to locate the lands which they were to deed to their fellow settlers; the duty of setting out and dividing the lots was at first given by special commission to Oglethorpe and later to other persons named for the purpose. It was customary that those commissioned to divide the land would survey and mark into lots all the lands covered by the trust deeds, and applicants for grants could then readily be satisfied without further surveys. Applicants were allowed some choice as to the lands they would receive, but this was regarded as a matter of privilege not of right. Possession was given to each grantee by the surveyor or other person authorized to divide the land. The Common Council planued that each settler would reccive a deed setting forth in detail the bounds of his lot and the terms on which it was granted; but in practice a mere memorandum was frequently the only evidence of title a grantee would receive. The sur- 
veyors were also expected to report regularly and fully to the Trustees as to the lands they had set out; but they were very negligent in performing this duty. ${ }^{60}$

This general plan of making trust deeds for large quantities of land to be subdivided was regularly followed by the Conmon Council in establishing all the settlements of Georgia which were to be peopled by charity settlers. A different course was pursued in conveying land to colonists who would bear their own expenses. It was customary that a man of this class who desired to secure a grant would appear either in person or by proxy before the Common Council of the general board of Trustees to present his petition for land. His proposal would be examined with eare, and he would be questioned as to his purpose in going to the colony. Frequently requests would be refused after this preliminary investigation; ${ }^{61}$ but if the proposed settler scemed to be in earnest and to be of good character, his petition would be deferred to a later meeting in order that his case might be fully investigated. The good character of the applicant was always a point greatly stressed. It is not to be inferred that the characters of the charity colonists were not also thoroughly examined; for all had to be apparently above reproach before they were regarded cligible to go to Georgia.

After a man's proposal had been approved, he was sometimes asked to present his servants before the Trustees for their approval. Next in order would be the payment of the fees which were usually one pound one shilling. A deed would then be drawn up and presented at the next meeting of the Common Council, usually the third meeting in the process of obtaining the grant. The seal of the Trustees

${ }^{6 n}$ B. T., Ga., XII : 4 et seq.

${ }^{\text {at }} \mathrm{C}$. R. II : 31 , for example. 
would be affixed to the deed in the open meeting of the Council, and the secretary would be instructed to countersign the grant.

When this had been done, two other steps were necessary; one of these was to file a record of the deed with the Auditor General of Plantations, and the other to send the deed to Oglethorpe or to some other agent in the colony who would be directed to lay out the grant and to put the owner in possession. Every precaution was used to prevent fraud, and all the transactions of which we have records seem to be entirely free from any taint of it.

Though this system was cumbersome, and though it was no doubt frequently inconvenient for at least eight such busy men as composed the Common Council to get together for such trivial business, the method proved very satisfactory for making grants to people living in England who wished to go to Georgia. It soon developed, however, that many people in America desired to move to Georgia or to secure grants in it who could not appear personally before the Common Council. Some of these were officers in the regiment of Oglethorpe, gentlemen from South Carolina, and others similarly situated. 'To arrange for such petitioners, it became customary for the officials or agents in Georgia to recommend that grants be made to such persons, and these recommendations were nearly always adopted. ${ }^{62}$

By 1735 the business of making reports to the Trustees of the grants in Georgia became so large that it was determined to establish the office of Register. Accordingly such an officer was appointed whose duty it was to record all grants, leases, and other conveyances; to keep an accurate account of the condition of the various grants that were made: and io render to the 'Trustees a monthly transcript ${ }^{02} \mathrm{C}$. R. 11: 112, for instance. 
of his records. ${ }^{63}$ As a general rule, the man who acted as register gave only a portion of his time to the duties of that office; and the work of nearly all who held the position was ineffective. Almost perfect records were kept of the grants that were made, for this information was incorporated in the minutes of the President and his assistants; but none of the register's seen to have collected information as to the improvements made on the lots granted, and none of them were careful to keep the 'Trustees well informed as to conditions in Georgia.

When in 17 the govermment of Georgia was reorganized and a president with assistants was given the chief authority at Savannali, there was an entire change in the methods of granting lots in the colony. This change affected all settler's whether going on eharity or at their own expense. From this time, most of the requests for land came from people in Ancrica; and so it was arranged that the president and his assistants in the colony should receive directly all petitions for land from persons in Georgia. They were empowered to take such action on the petitions as seemed wise, but the decisions they reached were subject to revision at the hands of the Common Council. As a matter of fact, the latter rarely investigated the decisions made by the authorities in the colony, but confirmed them almost automatically. In cases of doubt, the president and his advisers sometimes would not render any decision but would delay long enough to get a ruling from the Council. This was likely to cause serious inconvenience; for it always took a long while to send an inquiry to England and get a response; and this was particularly the case during the war period from 1739 to $17+8$. Since the Common Council met very seldom after $1 \%+1$, it came to be customary that the ${ }^{03}$ B. T., Ga., XII : 252. 
general board of 'Trustees would approve or disapprove the actions of the Georgia authorities; and the Council at its rare meetings would give a general endorsement to the proceedings that had been held both in the colony and in England.

While few applications were made directly to the Common Council for land grants, this body still retained in name at least the sole privilege of making the grants; and oceasionally a direct grant would be made by it as during the earlier part of the colony's existence.

Having noticed briefly the general methods of the Georgia land grants, we may consider some of the practical workings of these methods. For the effectiveness of the plans that were adopted, much depended upon the characters of the surveyors. Noble Jones was at first the regular surveyor, and others were employed by the Trust from time to time at fixed rates. Complaints were lodged against all of them at various times, but most of the complaints were on the score of tardiness in performing the duties of the office. During much of the proprietary period, there was only one surveyor for the whole province; and it is not surprising that the work progressed slowly. The Trustees themselves were perhaps stronger in their complaints than any of the settlers, for none of the surveyors were at all prompt in filing the reports that were required of them. ${ }^{64}$

Aside from the charges of delays and slowness, none of the complaints against the surveyors seem to have been well founded. Few mistakes and inaccuracies in the actual surreying were made. At various times disputes arose over boundaries, hut in nearly every case a reference to the old ${ }^{64}$ B. T., Ga., VIII : Martyn to Jones, May 29, 1735; C. R. VI: 210-241. 
surveys was sufficient to settle the diffieulties. ${ }^{65}$ It is probable that Georgia had as few uncertaintics as to boundaries as any of the British colonies in America.

The general rule as to the compensation of surveyors was that they should be paid by the Trust for surveying the fifty acre lots, but that the grantees of the larger grants would themselves bear the expense of the surveys. ${ }^{66}$ The average annual expense to the Trust for surveying from 1732 to 1748 was about fifty pounds; after that time the work of the surveyors was evidently self-supporting. The most satisfactory arrangement with the surveyors was to pay them a fixed rate per acre instead of a stated salary per year; for they kept closer to their duties when their wages depended upon their activity. The stipend usually paid was four pence per acre for tracts between twenty and fifty acres, three pence per acre for tracts of more than fifty acres, and six pence for tracts of less than twenty acres. Besides the surveying, these officials had for their duty the task of showing lands to prospective settlers and of putting grantees in possession of their lots, for which they were paid at the rate of five shillings per day. If errors were made, all these had to be corrected at the expense of the surveyor. ${ }^{67}$

Since a mere memorandum of land granted was given to the possessor, especially if the grant was for only fifty acres, many of the landholders of the colony did not have sufficient evidence to establish their claims. ${ }^{68}$ To remedy this situation, which was particularly inconvenient after the right to buy and sell lots had been granted, the 'Trustees

${ }^{\text {ts }}$ C. R. VI: 96, 141, 143, as examples.

Ibid., 29-23.

"Ibid., 130.

${ }^{\text {es }}$ Brief Account, etc., Ga. Hist. Collcc. II : 98. 
on March 29, 1749, determined to prepare proper forms for all those who needed to have their grants fully established. ${ }^{69}$

Georgia had almost no trouble with squatters during the rule of the Trustees, though something approaching that trouble scemed imminent in 1748. After Oglethorpe left Frederica in 1743 , there was no one in the southern part of the province deputed to recommend grants or to put applicants into temporary possession of them. The officer in charge of the regiment without being authorized to do so undertook to give possession to lands in that section of the colony. This was strongly resented by both the president and his assistants and by the Trustees, for they regarded the settlers thus placed on their lands as squatters; but there can be no doubt that it was a hardship for the inhabitants along the Altamaha to have to go to Savannah to petition for lands, and the commander was not without some excuse for his action. As a matter of fact, the grants thus illegally made were afterwards confirmed by the proper authorities; and, when the colony was surrendered to the crown, all those in the province who possessed land under any claims whatever were permitted to remain in control of it. ${ }^{70}$

\section{F. The Sise of Land Grants}

It would be interesting, were it possible, to trace in detail how the experiences and regulations of the other English colonies influenced the Trustees in their government of Georgia. In many details, they seem not to have been well informed as to the practices and customs of the other provinces; and in many other particulars they deliberatcly

$$
\begin{aligned}
& { }^{89} \text { C. R. II : } 497 . \\
& { }^{70} \text { C. R. VI : } 310 \text {, as an example. }
\end{aligned}
$$


departed from the rules followed elsewhere on the ground that Georgia was unique in purpose and in physical conditions, so that it did not necessarily require the same policies that other colonies had found best for them. In planning the Georgia land system as a whole, they certainly proceced on that assumption to a large extent; and it differed very decidedly from that of any other colony. Yet even in the land system, it is likely that the Trustees were somewhat influenced by the rules that were used in other colonies. For instance, the charter limited grants in Georgia to five hundred acres; this was the amount of land that had been fixed as a limit to South carolina after the evils of vast grants had become apparent. ${ }^{11}$ The Trustees fixed on fifty acres as a sufficient quantity of land for charity settlers; and this was the amount that each individual in South Carolina might obtain in 1731, the year before the Georgia charter was obtained. In fixing these amounts, the 'Trustees may not have been influenced by the Carolina regulations; but there is a probability that the suggestions did come from the experiences of the neighbor province. The small size of even the maximum grants fitted admirably with the purposes of the Trustees to keep the people as nearly as possibie on a level; for five hundred acres were not enough on which to found an aristocracy that would overshadow the humbler classes.

One of the first problems of the Common Council was to determine the conditions on which the maximum grants would be issued, whether to all who shonld go at their own expense or only to those who would meet additional conditions. The question was not solved at once, but various experiments were made to aid in the solution of the problem. The first group of grants to adventurers, as those ${ }^{71}$ Public Records of South Carolina, Mss., IV: 128. 
going at their own expense were called, varied from eighty acres to five hundred. The variation was due in part to a difference in the number of servants carried; but this was not the only basis of measure, for only eighty acres were given to one man who carried one servant, while two hundred acres were conveyed to another who also had only one servant. A man's personal character, his financial ability, his purpose in going to Georgia, and the amount of land requested were all important factors in determining the size of grant that the Common Council would give to him. ${ }^{72}$

Early in 1733, the Council fixed a general rule for making maximum grants, agreeing that five hundred acres would be given to any worthy person who would go to Georgia with six able bodied men servants, paying all his expenses. No definite rule was adopted as to the conditions for giving less than five hundred acres. ${ }^{73}$

It is somewhat amusing to find that the Trustees became alarmed during the second year of the colony lest the supply of land run short in Georgia; and they decided to make no more grants to adventurers until they heard from Oglethorpe that there was no danger of a shortage in land. ${ }^{7+}$ This is another instance illustrating how unaccustomed the Trustees really were to things colonial; for only the most inexperienced men in such matters could think seriously that a few grants of five hundred acres each would exhaust the good land in the vast territory of their grant.

The earlice rules adopted by the Common Council were for its own guidance and they were not generally published; but in 1735 it was definitely declared and widely published that to get five hundred acres of land an adventurer must

${ }^{72}$ C. P. II : 14-2Q.

${ }^{73}$ Ibid., 23, 30, 31 .

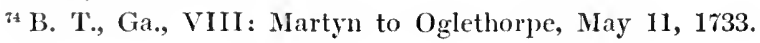


take ten men servants and pay an annual rent of twenty shillings per hundred acres. ${ }^{75}$

These rules were not strictly followed; for after this time there were numerous maximum grants to men who carried only four servants, and sometimes men were allowed to remain in England themselves and to merely send their servants to the colony. ${ }^{i 6}$ 'The fact is that the Common Council reserved the right to act as it thought best in each case, regardless of what the general rules might be. The tendency after 1735 was for the Trustees to become less rigid in enforcing their rules. We have already pointed out the fact that they changed their interpretation of the charter in regard to the amount of land that could be owned by one man; at first they held that the charter restricting their grants to five hundred acres at the same time fixed that amount as the limit which any one could possess in the colony, but they later agreed that possessions could be accumulated to the amount of two thousand acres. ${ }^{i 7}$ They also evaded in various ways the plain limitation on their granting more than five hundred acres. One method of evasion was to grant to a man the maximum acreage allowed and then to lease him an additional amount on such terms as would practically make the lease a free grant. ${ }^{\text {is }}$ Another evasion was to grant to a man's brother or nephew or friend a tract of land that by private arrangement between them could be held for the benefit of one to whom the Trustees could not legally grant any more land. ${ }^{79}$ Howerer, these evasions were not common enough to result in any large plantations in the colony.

It has been pointed out that the grants made to charity

is Voyage to Georgia, Ga. Hist. Collec. I: 80, 84.

${ }^{6}$ 13. 'I., Ca., XII: $960-965 . \quad{ }^{\circ 4} \mathrm{C}, \mathrm{R}, \mathrm{V}^{r}: 706$.

${ }^{7}$ C. R. II : 338.

ig Ibid., 989. 
settlers were fifty acres for each head of a family. This amount of land was deemed sufficient to support a family and not too much to be kept in good condition; but many of the fifty acre lots in the early distributions were laid out in poor land known as pine barrens, and this was very unproductive. On December 12, 1739, the Trustees ordered that enough land should be added to the estates of such persons as would increase their holdings of good land to fifty acres in addition to whatever of poor quality there might be. ${ }^{80}$

Two years later the officials in Georgia were enjoined to see that good land was given to each one whose grant had included that of poor quality, and it was to be allowed the grantec to choose his new land wherever he might find it most convenient. In addition, the Trustees agreed that when any freeholder of a fifty acre lot made it appear that he had improved the whole of it he might have the privilege of selecting another in the province wherever he might desire. ${ }^{81}$

In the early deeds to persons carrying servants to Georgia, it was specified that when the servants satisfactorily completed their terms of service they might each receive twenty-five acres of land. This quantity was later fixed at twenty acres, though in exceptional cases it might be made as much as fifty acres. ${ }^{82}$ In 1741 it was found that more encouragement was needed to make servants faithful and to induce others to go to Georgia to take the places of those whose indentures were expiring; and accordingly all the portions for faithful ex-servants were fixed at fifty acres. ${ }^{83}$

${ }^{80}$ B. T., Ga., IX: Verelst to Stephens, Dec. 12, 1739.

${ }^{81}$ C. R. II : 377 .

${ }^{82}$ Ibid., $23,74$.

${ }^{83}$ B. T., Ga., X: Verelst to Stephens, Apr. 24, 1741. 
When Oglethorpe's regiment was settled in Georgia, the Common Council proposed to encourage the soldiers to be industrious by giving to each one five acres of land for his own use and profit: and it was further agreed that if at the end of seven years of faithful service any soldier wished to leave the military life he might receive a grant of twenty acres. ${ }^{\text {st }}$ This would seem far from generous. A soldier who had been in the colony seven years and who had become acclimated and accustoned to the conditions of the country would be a much more valuable colonist than a raw settler from the streets of London; but for the latter the 'Trustees would pay transportation to Georgia, give a year's support, and grant fifty acres of land, while to the soldier who had resigned and who would probably be almost as needy as the Londoner only twenty acres were allowed.

After the president and his assistants assumed the management of making land grants, there were no decided changes in the rules that governed the subject; but in practice there were a number of important changes. The acreage granted no longer depended upon the number of servants employed upon the estates, but the determining factors were, somewhat as in the earliest days of the Common Council's management, the character of the applicant and his financial ability to improve the land he was secking. The old and the infirm were not allowed large grants. No grants were made out for unknown or fictitious persons. As a rule, it was more difficult for unworthy settlers to obtain lands than when the Common Council passed upon the applications. The records during this period make it easier to ascertain the proportion of petitions that were granted and of those that were rejected than at any other time of the colony's existence.

${ }^{84}$ B. T., Ga., XII : 359 et seq. 
Since careful records were kept of all land grants in the province, it is of interest to notice in tabular form the yearly cessions. These tables furmish a rather accurate index of the growth of the colony. Since the records of the first nine years do not admit of as great detail as those of the last eleven years, the summaries will be given in separate tables for the two periods. The main difference in the records is that after the president and assistants took charge of the applications for land, they made careful note of those that were refused, while the Common Council usually recorded only those that were granted unless the refusals were of unusual interest.

TABLE NO. I.

Land Grants in Georga from June 9, 1732, to October 19, $17+1$

In trust for subdivision into

Year.

1732-3

$1733-4$

$1734-5$

$1735-6$

$1736-7$

$1737-8$

$1738-9$

$1739-40$

$1740-1$ small tracts. 5000 acres 8100 "

2500 "

20000 “

3000 "

3000 "
To persons going at their own For religious

Totals 41600 acres

Grand total, 71185 acres

TABLE NO. II. (A).

Applichtions for I.Axp in Geongia from October 19, 1741, to June 23, 1752, That Were Favoraiby Considered.

$\begin{array}{lcccccr} & \text { Total No. } & 500 & 50 & \text { Town } & \text { Other } & \text { Total } \\ \text { Year. } & \text { of grants. } & \text { acres. } & \text { acres. } & \text { lots. } & \text { sizes. } & \text { acreage. } \\ 1741 & 15 & \mathcal{2} & 11 & 2 & & 1560 \\ 1742 & 36 & & 27 & 9 & & 1395\end{array}$




\begin{tabular}{lcccccr} 
& Total No & 500 & 50 & Town & Other & \multicolumn{1}{c}{ Total } \\
Year. & of grants. & acres. & icres. & lots. & sizes. & acreage. \\
1743 & 17 & 1 & 10 & 6 & & 1030 \\
1744 & 9 & 3 & 3 & 3 & & 1665 \\
1745 & 11 & 1 & 8 & 2 & & 910 \\
1746 & 7 & 3 & 3 & & 1 & 1950 \\
1747 & 41 & 16 & 4 & 2 & 19 & 19410 \\
1748 & 57 & 30 & 4 & 2 & 21 & 19744 \\
1749 & 32 & 15 & 3 & 3 & 11 & 9667 \\
1750 & 75 & 20 & 40 & 4 & 11 & 13660 \\
1751 & 25 & 4 & 5 & 1 & 15 & 5455 \\
1752 & 47 & 17 & 14 & 3 & 13 & 12515 \\
\hline Totals & 372 & 112 & 132 & 37 & 91 & 82011
\end{tabular}

TABLE NO. II (B).

Applications for Land in Georgia From October 12, 1741, to June 23, 1752, That Were Refised or Postponed.

\begin{tabular}{lrrrrrr} 
Year. & $\begin{array}{c}\text { Total No. } \\
\text { refused. }\end{array}$ & $\begin{array}{r}500 \\
\text { acres. }\end{array}$ & $\begin{array}{c}50 \\
\text { acres. }\end{array}$ & $\begin{array}{c}\text { Town } \\
\text { lots. }\end{array}$ & $\begin{array}{r}\text { Other } \\
\text { sizes. }\end{array}$ & $\begin{array}{r}\text { Total acre- } \\
\text { age refused. }\end{array}$ \\
1741 & 9 & 8 & & 1 & & 4005 \\
1742 & 8 & 8 & & & & 4000 \\
1743 & 19 & 18 & & 1 & & 9005 \\
1744 & 2 & 2 & & & & 1000 \\
1745 & 0 & & & & & \\
1746 & 5 & 1 & & & 4 & 1050 \\
1747 & 17 & 10 & 3 & & 4 & 5800 \\
1748 & 31 & 17 & & & 14 & 11250 \\
1749 & 37 & & 30 & & 7 & 3950 \\
1750 & 5 & 3 & & & 2 & 1700 \\
1751 & 0 & & & & & \\
1752 & 0 & & & 2 & & \\
\hline Total & 133 & 67 & 33 & 2 & 31 & 41760
\end{tabular}

In Table No. 1, all the land that was given in trust for subdivision is listed; but it is to be observed that a considerable portion of this was never distributed among settlers. It is impossible to tell just the proportion that was actually 
deeded to individual settlers; but it seems probable that about a third of it was never so used, so that the amounts of land granted to independent applicants and to those going on charity must have been very nearly equal.

Comparing the two sections of Table No. II, we find that during the last eleven years of proprietary rule the land grants that were refused amounted to just half the acreage that was really granted. The average size of the grants made was two hundred and twenty acres, while the average size of the applications that were declined was for three hundred and fourteen acres.

It seems remarkable that when Georgia needed colonists so greatly that so many applications for land were refused. It was the constant policy of the Trustees not to grant land for speculation; and the refusals between 1741 and 1743 were usually on the ground that the applicants were not financially able to handle the grants that were sought. Between 1746 and $17+9$, most of the applicants for land were men who wished to move from Virginia or the Carolinas to Georgia, and they expected to bring their negro slaves with them; the Georgia authorities thought it best to lose desirable settlers rather than to risk the violation of the slavery rules. After 1749 the law against negroes was not in force, and almost no refusals were made after that time.

It is surprising that during the twenty years of government under the charter so little land was granted for settlement. Including all that was granted in trust during the first nine years, the entire grants amounted to only one hundred fifty-thrce thousand acres, practically all of which if placed in one tract could have been included in a lot fiftcen miles square. These facts emphasize the point already made that the Trustees believed in and practiced a policy of economy in the granting of the lands which were com- 
mitted to them by the charter. ${ }^{\mathrm{s}}$

\section{G. Methods of Laying Out Grants}

It is an interesting fact that Georgia was largely settled in communities or towns sonewhat resembling those of New England. This was the result of the policy already mentioned of making trust decds for several thousand acres to be laid out and subdivided among the settlers sent over by the 'Trust. There were in all eight of these large tracts, varying in size from twenty-five hundred to ten thousand acres; and nuost of the people of the province were located in one of the towns or villages that developed from these trust deeds. Savamnah was the first of the towns to be established, and it served as a model for the later ones. Since this is true, it may be worth while to study the general plan of Savamnah as a type of the Georgia towns.

It was laid off for two hundred and forty freeholds, the quantity of land necessary being twenty-four square miles or fifteen thousand three hundred and sixty acres. Of this land, twelve thousand acres were used for actual grants to settlers, while the remainder was used for roadways, streets, Trust reserves, commons, and the like. 'The town proper' was laid off into wards of forty building lots each, and these wards were subdivided into tithings of ten lots each. Wide streets and numerous squares for market purposes were left; and in every ward was left one large square to accommodate people from the country if these should ever need to seek

${ }_{55}$ The material on which Talles I and II and the comments on them are based is so scattered that specific, references to sources are impossible. The facts are drawn from the Minutes of the President and $\Lambda$ ssistants, C. R. VI; the Ninules of the Common Council, C. R. II; and the Account Showing Progress, etc., C. R. III: 368 et seq. 
the protection of the town. Around the residence and business portions of the town were the commons which were planned for grazing cattle and for recreation. ${ }^{86}$

The building lots were each sixty by ninety feet, fronting two streets. Each owner of such a lot would have a garden plot beyond the town commons, and this was large enough to make the combined area of lot and garden amount to five acres. Still further from the center of town, but within the domain of the town, each settler was allowed a farm of forty-five acres, so that his whole estate would be fifty acres as planned by the Trustees.

As a rule, adventurers would not have their lands laid off within the limits of one of these especially assigned tracts, but they were given estates adjoining the towns or villages, though not infrequently they were allowed a building lot within the town for a residence only.

While the general arrangement of the Georgia villages, with Savannah as a type, was something like that of Massachusetts or other New England colonies, there were several points of difference that should be noted. In general appearance, the Georgia villages were much more compact, due to the small building lots, though the streets and squares were perhaps wider than the average ones in New England towns. This compactness was due to the fact that Georgia was designed as a buffer colony against the Spanish; and each town was therefore considered, and to a degree arranged, as a garrison.

In respects other than appearance, the settlements in Georgia were still more unlike the New England towns. 'The latter owned all the land within their limits and could prescribe what should be done with it, while in Georgia all vacant land was owned by the Common Council three thouso Yoyage to Georgia, Ga. Hist. Collee. I: 97-99. 
sand miles away. Again, a town in Massachusetts was to a considerable extent self-governing and could regulate entirely its internal affairs, while no Georgia village ever enjoyed this privilege under proprietary rule.

There were some decided disadvantages in laying out lots and farms so regularly. Much of the land in Georgia was not well adapted to cultivation; and it was impossible to find large tracts of it that would all be good. As a result, when towns were laid out and when the various divisions were distributed, some settlers would surely get poor land either for their gardens or for their farms or for both. ${ }^{\mathrm{si}}$

While most of the colonists in the earlier days were lo- $^{-}$ cated in villages, yet even at the beginning of the colony there were a few five hundred acre plantations located on streams or on other favorable sites. Islands were eagerly sought by many applicants, as they were regarded as particularly valuable; but they were reserved by the 'Trust for several years. ${ }^{s s}$ After the president and assistants took over the consideration of grants in the colony, the plantation came to be the most common form of settlement; for - no trust deeds of large tracts were made after 1738. In all country grants, care was taken to reserve roads to towns or to rivers, tow paths along streams, and other essentials for the welfare of the colony as a whole. 89

A reasonable effort seems to have been made to allow adventurers to select locations in the province best suited to their purposes. Care was also taken to mix the lands of each grant, so as to have some of it high and some low for crop variation; but these details depended largely upon the surveyor in charge. Vacant land was regarded as a detri-

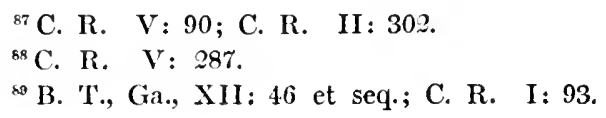

${ }^{87}$ C. R. V: 90 ; C. R. II : 302 .

${ }^{68} \mathrm{C} . \mathrm{R} . \quad \mathrm{V}: 287$.

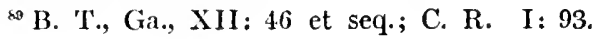


ment to all near it; and, to prevent having such, the lots of adventurers were laid out contiguously whenever possible. ${ }^{90}$

\section{H. Indian Land Grants to the Trustees}

It was the general policy of the Trustees and of the settlers of Georgia to recognize the Indians as the rightful owners of the soil; and no settlements were made during the proprietary period without the consent of the natives. Before the first colony landed at Savannah, Oglethorpe arranged for the settlement with the handful of Yamacraw Indians who lived in the neighborhood. This small tribe or group of natives made no claim to the entire ownership of the land, but acknowledged that it was vested in the nation of Creeks as a whole. Accordingly, after the Savannah settlement was well under way, a conference was arranged by Tomochichi between Oglethorpe and representatives of the eight principal tribes of the Creek nation. After a conference of several days, on May 21, 1733, a treaty was concluded. This contained regulations relating to both trade and land grants, but we are concerned only with the latter. The Indians gave a general grant of lands to the Trustees, yielding to them, their successors and assigns "all such lands and territories as we shall have no occasion to use, provided always, that they, upon settling every new town, shall set out for the use of ourselves and the people of our nation such lands as shall be agreed upon between their beloved men and the head men of our nation, and that those lands shall remain to us forever." ${ }^{91}$ In general, the understanding was that the English might settle all the lands between the Savannah and the Altamaha rivers from

${ }^{90}$ B. 'T., Ga., XI: Martyn to Parker, July 10, 1750.

${ }^{91}$ A. W. I. 535 (No folio cited). 
the ocean to the head of tide water. 'They also yielded to the Trustees all the islands along the coast except three, which they reserved with a strip of land along the Savannah river near the town of Savannah for the use of the nation. This treaty was approved by all the Indians aifected by the cession. The Upper Creeks were not represented at the meeting, but they later ratified the treaty, as did the Cherokees, though the claim of neither the Upper Creeks nor the Cherokees to this portion of Georgia, seems to have been very clear. No definite price was paid by the 'Trustees for the land grant. They presented valuable gifts to representative chief's and their followers; but these were regarded rather as tokens of esteen than as remuneration for the land. ${ }^{92}$

As new towns, such as Ebenezer, Augusta, Frederica, and the like were established, the Indians were usually assembled to assent to the settlements under the general treaty of 1733 . On these occasions, gifts of friendship were presented to the chiefs, but no mention was made of purchasing lands.

The most notable confirmation and extension of the treaty of 1733 was on the occasion of the journey of Oglethorpe to Coweta in the year 1739. Here in the heart of the Indian country, he met the chiefs of the Creek nation; and they ceded to the English all the coast with the adjacent islands from the Sarammah to the st. John's river as far inland as the tide flowed, excepting still however the three islands mentioned in the treaty of 1733 . The English agreed on their part that they would appropriate no lands except those ceded by the Crecks and that they woukd punish any one trespassing on the reserved lands of the Indians. ${ }^{93}$ This treaty differed in a number of particulars from that of 1733 .

${ }^{92}$ Polit. State of Great Britain XIVI: 237 et seq.

${ }^{93}$ 13. T., Ga., XXIV: Oglethorpe to Verelst, Sept. 5, 1739. 
It was made by Oglethorpe, not as a direct representative of the Trustees, but rather of the British government under whom he held a colonel's commission. The lands ceded extended considerably below the boundaries of Georgia, and these outside lands could not be held by the Trustees. The promises made by Oglethorpe in return for the land cession were not rendered in the name of the Trustees, but rather on the authority of the British government.

As a rule, the English were careful not to trespass on territory which the Indians had not granted. One of the few exceptions to this policy was the occupation of the Uchee lands near New Ebenezer. The Salzburghers who settled the town soon found that they had a scarcity of good land, while the Uchee domain which stretched for a hundred miles along the Savannah river afforded splendid soil. They desired that the Trustees take steps to purchase these lands; but Oglethorpe discouraged the movement in 1741 on the ground that the Indians might be offended and turn to the Spanish at that critical period, and nothing was done about the matter. The whites gradually encroached on the Indian lands, however; and this was resented by the natives who robbed and plundered the intruders. By 1746 the Uchees, who were a small tribe of the Creeks, had become much reduced in number and had withdrawn from the immediate English settlements, so that the president and his assistants thought there would be no difficulty in securing their lands for settlement. The matter was referred to the Trustees, who seem not to have considered it; but the Georgia settlers proceeded to occupy and use the lands without further trouble, so far as the records indicate. ${ }^{94}$

This incident is chiefly interesting because it was exceptional in the relations of the whites and natives and because ${ }^{81}$ B. T., Ga., XXII: 205 ; C. R. VI: 147-148, 339-349. 
it illustrates the dangers that might have resulted if the Trustees had not adopted a conciliatory policy toward the Indians.

The most difficult problem that confronted the carly Georgians in obtaining land from the Indians grew out of the tracts reserved by the Indians in the treaty of $1 \% 33$. It will be recalled that the reserved lands consisted of three islands along the coast and a strip of land near Savannah. An enterprising white man Thomas Bosomworth, who had been at one time the pastor at Savannah and who had married an Indian half breed, claimed to have secured for himself and wife deeds from the Indians to all the reserved lands; and he proposed to take possession of them. The 'Trustees clained all the territory within the limits of Geor-' gia under the grant of the king; and, while they were willing enough to concede that this might not extinguish all Indian claims, they held that no Englishman could have any right to lands in the colony except by the grant of the Trust. Logically it would seem that the Bosomworths had a fair claim to the lands. If it was conceded that the Indians owned the lands, there would seem to be no good reason why they might not deed them to Mrs. Bosomworth if they chose to do so. As a matter of equity, there was no doubt that the Bosomworths were attempting a land grabbing scheme on a large scale.

The Trustees determined to treat the whole deed to the Bosomworths as illegal, and they then attempted to secure a deed to these lands for themselves. Liberal gifts were furnished the Georgia authorities with which to carry on the negotiations. 'The Upper ('reeks willingly ceded their rights, which were indeed of very doubtful force; but the Lower Creeks, who were considerably under the influence of the Bosomworths, refused to cede their claims to the Trustees. 
Finally they were persuaded to grant a temporary loan of the land to the colony. The trouble began early in 1749 , and it continued to be one of the vexing problems of the province during the remainder of the proprietary control, being finally settled by compromise after Georgia became a royal province. ${ }^{95}$

Reviewing the whole of the land system of Georgia, we may conclude that it was very successful in its relation to the Indians, for it avoided friction with them and kept them contented; but it was a failure to a large extent in its relation to the white people of the colony because it stirred up friction between the settlers and the Trustees and because it did not make the colonists contented. The Trustees were really concerned to please the settlers, but at the distance of three thousand miles they could not understand the situation in Georgia. The land system was perhaps better administered in the province than any other department of the colony's affairs, and yet the local officials did not take the proper pains to let the authorities in England know what changes ought to be made. The fundamental weakness of the whole system was the multiplicity of restrictions of various kinds that were placed on landholders in Georgia. The entails, forfeitures, quit rents, requirements as to houses, requirements as to cultivation, requirements as to mulberry trees, penalties for leaving the colony, and penalties for numerous other deficiencies or neglects - all these were things that vexed the colonists and made them discontented and unhappy in spite of the fact that few cases of real hardship resulted from all those regulations.

${ }^{95}$ B. T., Ga., XI: Martyn to Parker, July 11, 1750; B. T., Ga., XXIII : 63 ; B. T., Ga., XXIV : 85. 


\section{CHAP'TER IX}

EDUCATION IN GEORGIA

NE of the pastors in Georgia in writing to his missionary society at home in 1739 stated that the Trustees were running so many schools in the province that they were unable to give any help to his field at Darien. ${ }^{1}$ Such a statement might lead one to infer that a rather full educational program was being carried out in the colony; but we shall find that this was far from being the case. It is true that the educational development of the province was perhaps as advanced as any other department of work; but at best it was scattered and weak. Besides, there were no very accurate records kept in the schools that were operated; and it is difficult to construct an account of what was done.

The work carried on in Georgia was of two kinds, religious and secular. The former was under the guidance of catechists who were really assistants of the pastors, spending most of their time in visiting from house to house and in working with the younger people of the colony. As a rule these teachers were paid by special contributions made for the purpose by charitably disposed persons or were supported by one of the missionary societies of the home land. Nost of the regular schools were under the direction of secular instructors. These teachers usually gave a certain amount of religious instruction, but this was not their prin-

${ }^{1}$ B. 'T., Ga., XXI: McLeod to S. P. C. K., Jan. 6, 1739. 
cipal business. They were nearly always paid out of the budget of the Trust. In our discussion here, it will not be necessary to consider at length the work of the regular catechists, for it properly belongs to the religious development of the colony.

The earliest suggestion of conducting a school in Georgia seems to have been made by Christopher Ortman, a German Protestant. As early as October 17, 1733, he appeared before the Trustees and proposed to go to Georgia as a schoolmaster and parish clerk for the Salzburghers who were soon to settle there. ${ }^{2}$ The Common Council of the Trustees tried to arrange for the support of such a worker through the Society for Promoting Christian Knowledge; but nothing seems to have come immediately of the negotiations. $^{3}$ By 1736 arrangements were made to send him to the colony partly as a catechist, but principally as a secular teacher. ${ }^{+}$Ortman was particularly urged to teach the Germans the English language. The rules of the Trustees required that this language be used in all legal and official business; and it was felt that the Salzburghers ought to master it as soon as possible. Ortman was an old man and poorly qualified to teach in any language. He could not speak English himself fluently and so could not give satisfactory instruction in it. In addition to this incompetence, he created friction in religious affairs at Ebenezer. As a consequence of the dissatisfaction that was felt with him on these two accounts, he was discharged. The pastor of the Salzburghers, Rev. John Martin Bolzius, was perhaps more than any other responsible for this action. ${ }^{5}$ Ortman

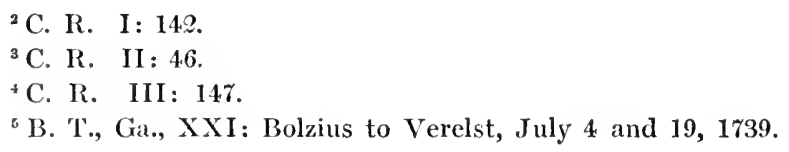


felt that he had been treated unjustly, and asked the authorities of the province to give him work, representing that he had been dismissed at Ebenezer without cause. The President and Assistants appointed him as schoolmaster at Vernonburgh and Acton, subject to the approval of the Trustees, agreeing to pay him $£ 5$ per year from the budget of the 'Trust if enough more could be raised to make the total salary $\mathfrak{£ 2}$ annually. ${ }^{6}$

The Trustees very promptly overruled the action of the Georgia authorities and ordered that Ortman be discharged from Vernonburgh and Acton. ${ }^{7}$ As a result of this dismissal, the old man at once became an object of charity and spent his last days most miserably. ${ }^{8}$ 'The experience of the colony with this first schoolmaster was repeated more or less accurately many times during the first twenty years of Georgia's existence.

After the dismissal of Ortman, the Salzburghers secured the services of a teacher named Hamilton; but he, too, was umable to give instruction in English, and he soon gave up the work. It is not necessary to follow the individual teachers that the Germans employed. 'Those employed during the last ten years of the 'Trustees' control seem to have given fair satisfaction. By $17+8$ the work had progressed sufficiently to necessitate a second school building for Ebenezer and the surrounding country; and a third was contemplated in 1752.10

'There is no evidence that the Trustees tried to do any educational work either at Darien or Augusta. These were both frontier posts where there were relatively few young

${ }^{\circ}$ C. R. VI: 121-122.

${ }^{7}$ C. R. II: 4 i $9-4$ So.

"C. R. VI: 203.

${ }^{9}$ B. 'T., Ga., XXII : Bolzius to Verelst, Nov, $15,1749$.

${ }^{10}$ B. 'T., Ga., XXIII: 60. 
people, so that the need was not so great as at other places; and, besides, the life was too strenuous for the people to think of much except making a living, defending themselves, and performing rather light religious duties.

The educational achievements at Frederica were not very notable. Rev. George Whitefield and James Habersham, who did so much for the Savannah region, planned at first to settle at Frederica; but they were finally more attracted by the northern part of the province. ${ }^{11}$ Nothing seems to have been attempted in southern Georgia until after the dangers of invasion by the Spanish had abated. In 1745 the Society for Propagating the Gospel in Foreign Parts suggested to the Common Council of the Trustees that if a schoolmaster were appointed for Frederica, it would agree to furnish him with a supply of books. ${ }^{12}$ In consequence of this offer, the Trustees appointed John Ulrich Driesler as teacher for Frederica, and they requested that he be appointed as chaplain of the regiment also so that he could secure a living salary, as the 'Trust was giving only $£ 10$ annually. ${ }^{13}$ The solution seemed a happy one, for Driesler was a faithful worker; and he gave daily instruction both in English and in German to the children of the region. ${ }^{14}$ However, he held the position less than a year before his death; and no one seems to have been secured to take his place.

The principal educational work of the province was done in the region of Savanmah. It was the center of greatest activity on the part of the Trustees, and it was there also that the greatest private exertions were made. The first

${ }^{11}$ C. R. I: 290.

${ }^{12}$ C. R. II : 445.

${ }^{13}$ Ibid., 460.

${ }^{1+}$ B. 'T., Ga., XXIII : 24. 
work that was contemplated was catechetical. Farly in 1734, Rev. John Burton, one of the 'Trustees, announced that he had received a donation for this purpose. The object was approved by his fellow menbers of the 'Trustec Board, and he was asked to nominate a suitable man for the work; but nothing further seems to have been done at that time. ${ }^{15}$

The first suggestion of a secular educational enterprise came in the form of a petition from John Burnside of Fort Argyle, on the great Ogecence river in the colony, who desired to start a "writing sehool" in Savannah. The Trustees ordered the magistrates in the colony to investigate the character of the petitioner and to grant him a license for conducting a school if he proved to be a suitable person. ${ }^{16}$ It is not entirely clear whether Burnside ever established his school or not. If he did make the attempt, it could not have met with much success, for no further development of the scheme can be found.

The next educational enterprise near Savamah was the establishment of work among the Creek Indians and the founding for them of a school named Irene. This undertaking was made largely under the direction of the Moravian settlers who had come to Georgia in 1735. The school was founded soon after their arrival and settlement. It was located on an island in the Savannah river about five miles above the town of the same name. The island was the favorite resort of the Creek Indians. Tomochichi, the best friend of the white people among the natives, had his village there: and he took a keen interest in the school. ${ }^{17}$ Peter Rose and his wife, Anthony Seyffart, Biener, and other

${ }^{15} \mathrm{C} . \mathrm{R}, \mathrm{II}: 55$.

${ }^{1}$ P. T., Ga., VIII : V'erelst to Bailiffs, May 15, 1735.

${ }^{17}$ I osliel, Part II : 3-4. 
Moravians made their homes with the Indians, adopting their manner of life and seeking in every way to win their confdence and friendship. In this they were remarkably successful. They soon succeeded in learning the Creek language. In 1736 they were joined by Rev. Benjamin Ingham who had come from England to teach the natives. ${ }^{18} \mathrm{He}$ proved to be a very able assistant and made a beginning of a Creek grammar in order to give the Indians the Bible in their own tongue, but the work was never completed.

In spite of the fact that the Indians were friendly to their instructors, it was not an opportune time for doing effective work among them, for the natives were in constant ferment. One of them remarked to Wesley, "Now our enemies are all about us, we can do nothing but fight; but if the beloved ones would ever give us to be at peace, then we would hear the great Word." 19

In 1737 Ingham returned to England in order to get more assistance for carrying on the work in Georgia. ${ }^{20} \mathrm{He}$ probably could have succeeded in his mission, for there was considerable interest in England at that time in the school work of Georgia; but John Wesley returned the same year feeling that he had been outraged by the Georgia people, and Charles Wesley, who had returned the year previous, felt also much dissatisfied with the colony. It is highly probable that their influence over Ingham prevented his return to the work at Irene, not that they tried to dissuade him from it, but it was largely because of friendship for them

${ }^{18} \mathrm{John}$ Wesley in his "Journal" says that the land on which the school was built was granted to Ingham. This seems a little improbable, though it may have been granted to him and to the Moravians jointly. The Brethren were evidently the leaders in the enterprise.

${ }^{19}$ Wesley's "Journal" 42.

${ }^{20}$ Ibid., 44. 
that he went to Georgia, and their return under such circumstances would naturally influence him.

The Moravians continued the Irene work as long as they lived in Georgia; but the educational feature of the work was less and less emphasized after the departure of Ingham. In 1740 when the Brethren left Georgia for Pennsylvania, the workers left Irene, and the school house was closed.21 A little later, on the invitation of Whitefield to co-operate with him in an educational and evangelistic campaign among the natives, they sent John Hagen to try to renew the work at Irene; but the Indian men had gone to Florida to engage in the war against the Spanish; and he could not make progress in reaching the women and children, so that the work was permanently dropped.22

The 'Trustees had been anxious for the Indian school to succed, and they supported it more liberally than many of the other colonial enterprises. During the first full year of work, they contributed about $15 t$; the next year they gave $\$ 162$; for the third year, the contribution amounted to $£ 167$; while during the last year, when the work was falling to pieces, they spent $\mathbb{L}^{*} 6$ on it. 23

In February, 1736, the first regular school of any consequence was begun in Sarannal. It was organized and taught by Charles Delamotte. He had come to Georgia with the Wesleys and Ingham in order to do missionary work among the Indians; but he found it impracticable to reach them at that time, and in consequence he turned to the teaching of the little children of Savamnah. He soon had an enrollment of thirty or forty whom he taught to "read, write, and cast accounts." Before the morning session, and after school

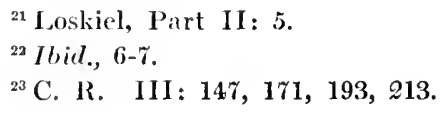


closed in the afternoon, he catechised the lowest classes in order to give them some religious instruction. In the evening he would also catechise the larger children; but the religious work was not a compulsory part of the school course. ${ }^{2+}$

Delamotte was the son of a sugar baker in London. He was well educated and was an unusually earnest Christian. He came to Georgia to serve without salary, ${ }^{25}$ and he received no remuneration. A small portion of his expenses were paid by the 'Trustees, but he bore most of them himself in addition to donating his time to the cause. ${ }^{20}$ His work as a teacher was of the highest order, calling forth the commendation even of those prejudiced against him. No teacher during the whole period with which we are dealing was more faithful or more beloved. When he left Georgia, the people as a body accompanied him to the boat to bid him farewell. It is probable that the strongest influence that led to his leaving Savanuah was the treatment accorded his friend John Wesley, but he did not mention this publicly, assigning as his principal reason for going a desire to enter into his father's business. ${ }^{27}$

The work given up by Delamotte was in a measure assumed almost immediately by another able man James Habersham. The latter came to Georgia as the companion and assistant of Rev. George Whitefield. He was very young at the time; but he cheerfully gave up the offers of assistance from friends in England if he would remain there, and faced the disapproval of his guardian, in order to engage in the service of the new colony. Whitefield and Habersham had planned before leaving England for the building of an

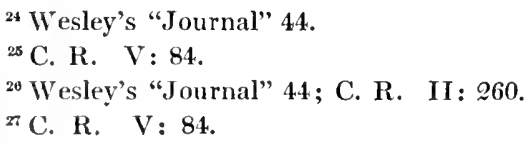


orphan house in Georgia, but they did not expect to engage in the work at once. However, when they reached Savannah, they found the need of an orphanage so great that they determined to proceed immediately with the enterprise. It was agreed that Habersham would conduct the sehool which Delanotte was giving up and that he would make a special effort to gather into it such children as might be eligible for the orphanage, while Whitefield nude a preaching tour for the purpose of securing funds for the undertaking. He seems to have contemplated at first raising the funds in America, but finally decided to return to England, partly to be ordained to the full priesthood of the Church of England and partly to raise noney for his work. ${ }^{2 s}$

After Whiteficld had received his ordination, he entered vigorousty upon his campaign for money and was successful in securing about $\mathbb{1 1 , 0 0 0}$ for his object. Before he had left England in the first instance, he had secured about $£ 300$ that could be applied to the work; and he felt that the combined funds were sufficient to begin the orphan house. Accordingly he applied to the Trustees for a grant of five hundred acres of land on which to erect the building, requesting at the same time that he be allowed the full management of the undertaking and agreeing that he would be responsible both for the buikding of the plant and for the salaries of those teachers and workers who might be employed. The Trustees agreed to his proposals in general, but retained the right of supervising the work. ${ }^{29}$

While Whitefield was in England, Habersham continued the school work in Savamnah with considerable success, training the rhildren both in secular and in religious education. He was all the while investigating those who might be suitable

${ }_{28}^{28}$ B. 'T., Gin., XXl: Whitefield to Verelst, July 1, 1738.

${ }^{29} \mathrm{C} . \mathrm{R} . \mathrm{V}: 162,173-174$. 
for orphanage wards when the work could be opened. As soon as he was notified of the grant of the five hundred acres, he began a search for the best location available and finally selected a tract of land about ten miles from the city. It was located near some of the principal plantations of the colony. On the east lay the island of Hope where Noble Jones had a fine estate; to the north was the farm of Secretary William Stephens; and other prominent men had settled in the vicinity. ${ }^{30}$ In addition to selecting the lot, Habersham was also active in collecting building materials and making all other possible preparations for the coming of Whiteficld who would take charge of the building operations proper.

It had been the plan of the associates to provide quarters for only about twenty orphans; but when they began to build they found the need so much greater than they had at first realized that they more than doubled the size that they at first intended. In his enthusiasm, Whitefield also determined to take charge of the orphans immediately, before the foundation of his new structure was laid. To accomplish this new purpose, it was necessary for him to lease a large house at a high rental; and in this he accommodated about twentyfour of the most needy. The school was not confined to those who were residents of the home; indecd it was open to all the children of the province whether orphans or not. No charge was made to any orphans, and the poorer parents were allowed to send their children free; but those who were able to pay tuition were charged a reasonable rate.

On March 25, 1740, Whitefield began the erection of the buildings for his educational plant. He himself laid the first brick of the main building, and he named the institution "Bethesda" or "House of Mercy." The expenses of carry${ }^{30}$ B. T., Ga., XXI: Whitefield to Verelst, Jan. 28, 1740. 
ing on the task were greater than had been estimated, for workmen had to be brought from other colonies to do some of the work and the cost of materials was also greater than in some of the more settled portions of the country. To meet the increased expenditures, Whitefield found it necessary to canvass the colonies in America. Accompanied by two of his most faithful assistants, he went northward meeting with favorable receptions everywhere and collecting about $\$ 500$ for his work. The principal part of this sum was collected in Pennsylvania, where Whitefield was planning to start a school for negroes. 31 This sum was not sufficient to continue the building satisfactorily, and he determined to make a trip through New England for further collections; but it was necessary to plan for the conduct of the institution in his absence before he should be away longer. ${ }^{32}$

While in England during 1738-1739, Whitefield had not given lis time exclusively to the collecting of money. Te had also been busy in sceking for men who could help in the teaching at Bethesda and in helping to manage the institution. One of the most promising associates secured was William Seward who had been a stock broker in London and

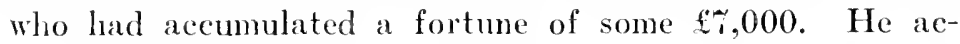
companied Whitefield to Georgia and entered heartily into the work.33 Another assistant secured was a Mr. Simms who was both a teacher and an assistant in religious work. Still another was a Mr. Peryam who had been bred a lawyer but who joined the orphanage group as an instructor in the school. ${ }^{34}$

On the expedition to Pennsylvania, both Habersham and Seward accompanied Whitefield, leaving the institution in
${ }^{31}$ C. R. V: 375 ; C. I
${ }^{33}$ C. R. V : 40?
${ }^{83} \mathrm{C} . \mathrm{R} . \mathrm{IV}: 588-589$.
${ }^{34} \mathrm{C} . \mathrm{R} . \quad \mathrm{IV}: 549$. 
the hands of the younger men. This was not regarded by those interested as a safe thing to do; and it was now arranged that Habersham would have permanent charge of the teaching and building at the orphanage, that Seward should go to England to interest others in the enterprise and if possible secure another good man to assist Habersham, and that Whitefield himself should give his time for the present to field work in behalf of the cause. ${ }^{35}$

On August 19, 1740, Whitefield left for Boston to begin a canvass in New England. Again he was very suecessful in arousing interest and collecting money; and he brought back to Georgia either in money or in provisions about $\mathfrak{£} \%$. In the meantime, the mission of Seward to England had been a failure. While preaching the new Methodist doctrine in Gloucestershire, he wats wounded in the heid by a stone thrown by one of his hearers; and he died as a result. ${ }^{36}$ His death was a serious loss to the orphanage. He left no money to the institution, and it was cut off from the financial help which he had been giving. Besides, there was no one left to represent the cause in England; and it necessitated Whitefield's going there in person. Seward had not gotten in England the workers he sought to help in the management of the orphanage, but Whitefield brought back with him from New England a Presbyterian minister, Rev. Jonathan Barber, to help in the conduct of the work. When he left for England on December 30, 1740, he left the business management of the home and plantation to Habersham and the spiritual guidance to Barber. ${ }^{37}$

In the meantime, the number of those receiving the bene-

${ }^{35}$ B. 'T., Ga., XXI: Whitefield to Trustees, May 19, 1740; C. R. $\mathrm{V}: 3.5 \pi-3.58$.

${ }^{30}$ C. R. V: 402.

${ }^{37}$ C. R. IV Supplement: 5\&, 64, 116. 
fits of the enterpuise had greatly increased. By March, $1 \%$ the the number of orphans lad reached forty and the whole number of children, officers, servants, and laborers exceeded a liundred persons. As summer came on and the work on the buildings could progress more rapidly, the whole number in the orphanage family were about one hundred and fifty. By the close of $1 \%+1$, the number of orphans had increased to sixty-eight, the high water mark of the institution under the proprictary control of the province; and the number of officers and employees was still large. During the year 1741 a young gentleman of Boston visited the orphan house, and he wrote a description of the management: "The bell rings in the morning at sumrise to wake the family. When the children arise, they sing a short hymn, pray by themselves, go down to wash; and, by the time they have done that, the bell calls to public worship, when a portion of Scripture is read and expounded, a psatm sung, and the exercises begin and end with a prayer. Then they breakfast, and afterwards some go to the trades, and the rest to their mayers and school. It noon they all dine in the same room, and have comfortable and wholesome diet provided. A hymn is sung bofore and after dimmer. Then, in about lalf an hour, to school again; and between whiles find time enough for recreation. A little after sunset, the bell calls to public duty again, which is performed in the same manner as in the morning. After that they sup, and are attended to bed by one of their masters, who then prays with them, as they often do privately." ss Some of the 'Trustees were not at all pleased with this program; they felt that there was entirely too much praying and singing and too little recreation. The discipline also seemed to them ${ }^{38}$ Quoted from Whitefield's Work by Stevens I: 352-353. 
too strict. $^{39}$

In the colony, too, there were complaints of the severity of the managers, especially $\mathrm{Mr}$. Barber, in dealing with the children under their care. In one case, the complaints were so bitter that Barber was summoned under warrant to appear before the magistrates in Savannah to answer for cruelty. He did not deny resorting to somewhat stringent measures to keep order among the boys at the orphanage, but he claimed that the discipline did not amount to cruelty and that the Trustees had given disciplinary authority to the managers of the institution. He was not punished, but he was warned that the magistrates would in the future inspect the orphan house and see that there were no further abuses. ${ }^{40}$

The orphanage was making a successful start, and the plantation on which it was located was being rapidly developed, when all progress was stopped by the Spanish invasion of the colony in 1742. The orphan house was located on the water at some distance from the Savannah settlement and from any fort or protection of any kind. The inhabitants became greatly alarmed; and Habersham determined that it was best to move all the children to the estate of $\mathrm{Mr}$. Hugh Bryan in South Carolina. The step was criticised by many as indicating a lack of faith on the part of Habersham and Barber and their associates; but under all the circumstances it was perhaps a wise precautionary measure, though later erents proved that they would have been perfectly safe if they had remained on their own plantation. ${ }^{41}$ After the Spanish had been repulsed, the work of the institution was renewed; but it never prospered again as it had done prior to this interruption.

$$
\begin{aligned}
& { }^{39} \text { C. R. } V: 359 . \\
& { }^{41} \text { C. R. VI } 41 .
\end{aligned}
$$

${ }^{\text {th }}$ C. R. IV Supplement: 16 -168 . 
In 1742 the newly appointed pastor of Savannah, Thomas Bosomworth, wrote to the Trustees a long and bitter denunciation of the methods employed by the teachers of the orphan school. He claimed that this institution did not properly care for either the bodies or the souls of its students, and that it neglected to teach them trades. He asserted that there were in the home only fourteen orphans from Georgia and that the others were gathered from all parts of the world. He accused the teachers of abusing all the ministers of the church of England and of instilling into the minds of the children prejudiees against sound doctrines. He declared that they encouraged laziness by teaching the youths under them to spend too much tine in prayer and meditation instead of engaging more in good works. Bosomworth also thought that the 1)issenter principles taught at the orpluan house would be very dangerous if generally accepted in Georgia. ${ }^{42}$

We have previously noticed that the Trustees were not altogether pleased with the managenent of the orphanage. The letter of Bosomworth convinced them that it was indeed to be condemned; and they sent to Habersham one of the most stinging criticisms ever given to one of their Georgia people. They disapproved strongly of his apparent contempt for the ministers of the Established Church. They complained of the methods used to excite and terrify orphans so as to keep them praying and erying all night for Jesus Christ. They suggested to him that he make religion appear more amiable to his charges. Finally they warned him that the institution and all its affiars were under the control of the magistrates at Savannah, who had been ordered to make frequent inspection of the work of the school. ${ }^{43}$

42 13. T., Ga., XXII: Bosomworth to Trustees, March 10, 1742.

${ }^{43}$ 13. T., Ga., X: Martyn to Iabersham, May 10, 1743. 
All the correspondence and reports of the period serve to give a rather clear view of what the orphan school was doing. It was to some extent industrial, endeavoring to teach each student some useful occupation; but this feature of the work was not emphasized very strongly. It was rather thorough in the secular instruction given in the school room, and considerable stress was placed upon it. But the main object of the whole institution was to make earnest Christians. It was charged against Whitefield that his sole purpose in founding the institution was to "establish a school or seminary to breed up those in his sect in." 44 This is not just to him, for, while he was an enthusiastic Dissenter, he did not adhere to his independent principles when the orphanage work was begun and he did not limit his charity by any means to those who would accept his doctrines. It is true, however, that he very earnestly desired for all his flock to be Christians.

We have previously referred to the fact that late in 1740 Whiteficld left the colony for a money raising campaign in England. He found this to be a difficult matter. All the leading pulpits of the Church of England were closed to him, for he was undoubtedly a Dissenter. His break with the Wesleys on the subject of doctrine alienated many of the Methodists from him. At this time he owed about $£ 1,000$; and he was being even threatened with arrest for the debt. However, he bent all energies to the task, and he was finally successful in raising the amount that was immediately necessary. Scotland, England, Ireland, America and even the Bermudas had to be appealed to, however, before the task was accomplished. It was manifestly necessary to reduce the expenses of the institution, and the number of inmates had to be lessened. By 1746 there were 4) C. R. V: 359 . 
reported to be in the orphanage only twenty small boys and girls. ${ }^{45}$

In order to supplement the deereasing revenues of Bethesda, in March, 174\%, Whitefield purchased a plantation of six hundred and forty acres in South ('arolina to be cultivated by slave labor. ${ }^{40}$ He had followed this policy in $17+1$ on a smaller scale with success. Now again he found that the use of negroes was profitable; and the following year he wrote a strong letter to the Trustees telling of his experiences. He said that he had spent more than $\$ 5,000$ on Bethesda, and that not half that amount would have been needful if slaves had been allowed in the colony. He stated also that in South Carolina he raised more in one year than in several years at the orphanage and at only one-fourth the expense. ${ }^{4 \pi}$ In this matter, Whitefield failed to take into account that Bethesda was not a commercial enterprise. Its prime object was to be a training school, and much of its labor was done by boys who were being taught how to work; they were not being exploited for profit. It was not fair to compare the results with those of enterprises on a mere financial basis.

There were no further developments at the orphanage of any great importance from $1 \%$ ts until the Trustees surrendered their charter in 1752 . The institution was carefully run. The Trustees became more kindly disposed to it. They had been very suspicious of Habershatm both as to his character and motives: but he came to be one of their most trusted officers; and with a better feeling toward him came a better understanding of the institution that he was so largely instrumental in rumning.

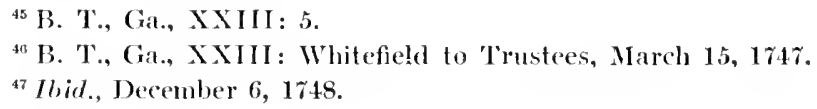


Before turning aside to trace the history of the Bethesda orphanage, we were recounting some of the main facts regarding the 'Trustees' school in Savannah. We shall now return to that subject. So long as the orphanage school was conducted within the precincts of Savannah, the 'Trustees seem not to have felt it necessary to operate a separate school; but when the orphans were transported to Bethesda on November 3, 17t0, it was once more important to have a teacher in the town. A man by the name of John Dobell had been an assistant both of Delamotte and of Habersham, and he took charge temporarily. In the early part of 1741, he went to England and sought from the Trustees an appointment as the regular teacher. ${ }^{+}$His request was granted; and he was on December 5, 1741, appointed to the position sought at a salary of 110 per year. Since this would afford but meager support, he was also appointed register of the province. ${ }^{49}$ While Dobell was in England, the school was conducted by the pastor of the Savannah church, Rev. Christopher Orton; and he was still to exercise general supervision over it, airecting the work of the schoolmaster. ${ }^{50}$

Ever since the establishment of a school in Savannah, it had been intended to be free to those who were unable to pay tuition; but the schoolntester had been supposed to collect fees from those having ability to pay them. This arrangement had never been very satisfactory, for it was a difficult matter to determine who ought to pay the tuition and who ought to be exempted. On June 14, 17 to, Schoolmaster Dobell petitioned the President and Assistants of the colony to act with the minister in making out a list of those who

${ }^{48}$ C. R. II : $37 \%$.

${ }^{49}$ B. 'T., Ga., X: Verelst to Stephens, Feb. 16, 1749.

${ }^{50} \mathrm{C} . \mathrm{R} . \mathrm{V}: 653$. 
ought to have free education." ${ }^{11}$ 'They accepted the responsibility; but they found the task abont as difficult as the schoolmaster himself had done. The question was referred to the Trustees; and finally on April 18, 17+3, the Common Council resolved that it would be best to make the school free to all the children of the colony irrespective of their ability to pay. 'To compensate the teacher for the fees he might lose in making the change, they doubled his salary, making the total stipend from the school f20 per year." Possibly the main reason for this action at the time it was taken was the fact that John Dobell had just presented a very discouriging report from the school as it was being run. He had only eleven pupils. He ascribed the small number to the dislike that many of the poorer people had to receiving education as charity from the Trustees. It was a curious circumstance that they should hesitate to accept tuition free when they had gotten in the same way their passige to Georgia, their lands, and much of their physical support; but the Trustees felt that it was better to yield without argment in the matter; and the school was made entirely free to all on the assumption that the abolition of distinctions between the rich and poor would tend to increase the school attendance. ${ }^{53}$ As a matter of fact, the change had little appreciable effect on the number of students. Before the news of the free tuition reached Savannah, Dobell had worked up the number to twenty-five, of whom five paid fees: and this was about the average attendance for some time. 54

On February g8, 1746, Dobell wrote to the 'Trustees ask-

${ }^{51}$ C. lR. VI: 35.

${ }^{62}$ B. T., Ga., X: Martyn to Stephens, May 10, 174.

${ }^{63}$ B. T., Ga., XXII : 78.

"Ibid., 121. 
ing to be released from his duties as schoolmaster in order that he might give more attention to his other work; ${ }^{55}$ but before he had time to get an answer to his request he resigned from all the positions which he held in the colony. ${ }^{56} \mathrm{He}$ secms to have been offered more remunerative work in Charleston; and he was not getting along very peaceably with some of the Georgia officials. As a teacher, he seems to have been well liked by most people of the province; but as register he did not have the confidence of the other officers, and he was constantly sending to the Trustees bad reports of them. ${ }^{57}$

His resignation came as a complete surprise to the President and Assistants, and they resented it, immediately withdrawing a grant of land that had been made to him but which had not been given in possession to him. 'They were also much puzzled to know how to keep the school going. ${ }^{58}$ The 'Trustees regretted very much to lose his services, and they wrote to him at Charleston asking him to return and promising him a valuable consideration if he would do so $;{ }^{59}$ but he would not give his consent.

It was a dificult matter to secure a good man to take the Savannah school; for few of the settlers were qualified to teach, and the remuneration was poor. It seems to have been more than three years after Dobell's resignation before the Trustecs were able to elect another teacher. In the meantime, Peter Joubert was employed by the Savannah authorities to conduct the school. He did not give satisfaction. He neglected the work and was much addicted to drunkenness, setting a bad example before the children. Finally
${ }^{55}$ B. 'T., Ga., XX II : 208.
${ }^{5}$ B. T., Ga., XXIII : 5.
${ }^{57}$ Ibid., 5, 9, etc., as examples.
${ }^{5}$ C. R. VI: 158-160.
${ }^{50}$ C. R. II : 479. 
after many complaints by the pastor and by the patrons of the school, the President and Assistants, finding that their admonitions to him were of no avail, discharged Joubert from the colonial service. ${ }^{\text {io }}$

In $17 \pm 9$ the 'Trustees appointed Fdward Holt to act as

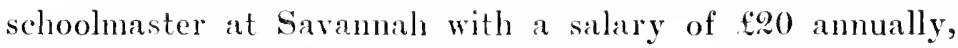
which was to be supplenented with $\$ 5$ more if he would act as parish clerk."1 He was an old man, and he did not make a good impression on the people whom he was to serve. Mr. Zouberbuhler, the minister at Savannah, wrote the Trustees that he was not fit to assist as clerk and that he and his wife enjoyed tattling too much for him to succeed as a teacher. ${ }^{62}$ He was plainly not qualified to give good instruction; but it was on account of his attitude toward the officials of the colony that he soon came into serious trouble in the colony. He lad hardly arrived in the province before the patrons began to complain that he was treating his pupils too harshly. The matter was brought repeatedly before the masgistrates; and finally on October 17, 1750, they felt compelled to examine the trutl of the reports. 'They sent a messenger to request the presence of $\mathrm{Mr}$. Holt at the council meeting; but he refused to obey the summons, saying that he would come when he found time. The magistrates sent again urging his immcriate attendance upon them, but he again refused to come. His insolence caused them to send an officer to arrest him and bring him to court; but when he was brought into the presence of the magistrates he was so abusive of the minister and of the officials of the colony that the investigation could not proceed, and he was ordered into confinement, scornfully refusing to acknowledge

C. R. VI: 303.

${ }^{61}$ B. 'T., Gia., X: Martyn to Pres. and Assts., Nov. 24, 1749.

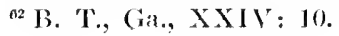


the authority of any one in the province over him. The next day the minister and one of the magistrates went to see him in prison to ascertain if he wcre not softened, but they reported that his behavior was worse than before. Finally the magistrates were so moved with compassion for his decrepit body that they released him from prison. They suspended him from acting as public schoolmaster, but permitted him to run a private school if he could find any parents still willing to send to him.

It was not long before Holt discovered that he could not find support in rumning a private school, and he became as humble as he had formerly been insolent toward the minister and the magistrates. After he had confessed his faults of the past and given assurance for the future, he was restored to his position; and his conduct gave such general satisfaction that he soon had a very good school of forty-one children, though there were still many that needed to be in school. ${ }^{6+}$

For several months, Mr. Holt seemed to get along very nicely with his work, but by August of 1751 the colonial Council reported to the Trustees that he was becoming unruly again, and that another person had started a school in Savannah and was taking away most of the students from the public school. ${ }^{65}$ There is no information available as to who it was that afforded the successful competition with the Trustees' school. The 'Trustees felt that they could not much longer bear with Holt, and in 1752 they authorized the magistrates to send him to England at the expense of the Trust. $^{66}$ The proprietary period closed without there be-

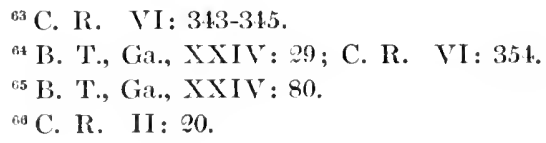


ing in the colony any regularly appointed schoolmaster for the white children of the Savamah region.

In estimating the scope and effectiveness of the educational work done under the 'Trustees for Georgia, we must take into consideration the difficulties encountered. The inhabitants of the colony were widely scattered. They were very poor and therefore unable themselves to help much in the promoting of education. 'They represented many diverse nations and languages and religions. When communities were populous enough to afford a good school, these varied language or racial differences made it frequently impossible for one teacher or one managenent of a school to meet the needs of all the people. The Trustees were three thousand miles away and could not appreciate the conditions in the province; it was therefore difficult for them to select teachers as wisely as if they were on the field.

The educational results in Georgia were admittedly meager. Only the most elementary instruction was attempted. Only one school in the province, the orphanage, was run with regularity. The teachers as a class were poorly equipped for their duties and were not paid living salaries. Bethesda was the only school in the province that had anything like a satisfactory equipment, and it did good work; but during the larger part of its existence it was mable to meet the needs even of the colony's orphans, leaving untouched the other children of the province. Although far from sufficient for the needs of Georgia, its schools were nevertheless about as good as those of some of the provinces that had been longer established; and they turned out many students who later developed into able and useful men. 


\section{CHAPTER X}

RELIGIOUS DEVELOPMENT OF GEORGIA

I order that we may understand the religious work that was attempted in Georgia, it will be advisable for us to notice briefly some of the organizations or agencies in England that co-operated with the Trustees in promoting and largely sustaining the efforts to Christianize both settlers and natives. The oldest of the societies that were active in carrying on the religious undertakings in the colony was the Society for Promoting Christian Knowledge. It was organized in 1698 by Dr. Bray, Lord Guilford, Sir Humphrey Mackworth, Justice Hook, and Colonel Colchester; but Archbishop Tennison and Henry Compton, Bishop of London, were the leading men who presented the matter to the government and secured a charter. The principal objects of the organization were to furnish gratuitous instruction to the poor, to provide cheap Bibles and religious literature for distribution, and to assist in carrying on missionary work in the British colonies and in foreign countries. ${ }^{1}$

Before Georgia was settled, this society had given up its purpose of appointing and sending missionaries, having surrendered this function to another organization; but it still collected and expended money for the furthering of this work. Its principal activities in Georgia were the transporting of the Salzburghers to the colony, the payment of ${ }^{3}$ Perry-Hist. of Church of Eng. 561. 
the salaries of a pastor and other workers for them, and the making of contributions to other salaries for catechists. We have already mentioned that the society for Promoting Christian Knowledge did not continue the full missionary program with which it began its work. It soon found that it had too many objects for them all to be properly administered by one organization; and in 1\%01, under the guiding influence of Dr. Bray who was so infuential in starting the original plan, a separate corporation was founded for the specific work of spreading the Gospel outside the realm. It was called the Society for the Propagation of the Gospel. in Foreign Parts, being also spoken of sometimes as the Venerable Society, and being perhaps more familiarly known as the S. P.G. ${ }^{2}$ 'The work of this organization was intended to unite the interest and activities of all the clergy of the Established Church. All the bishops of the realm were to canvass for such clergymen as were willing to go as missionaries. 'Those secured for this purpose were to report to the Secretary of the Society who would co-operate with the Bishop of London in deciding where they should labor. All missionaries must report to the Archbishop of Canterbury and to the Bishop of London for instructions. They were required to correspond regularly with the Secretary of the Society, to send every six months a statement of the condition of their parishes, and to communicate whatever else might be of interest and concern to the Society. It did not obtrude the Episcopal service on the colonies; and it did not send missionaries until asked to do so by the people among whom they would liabor and until adequate support for them could be provided. ${ }^{3}$

'This Society had slender means, but it did an excellent

${ }^{2}$ Cross-Anglican Episcopate 35.

${ }^{3}$ Dalcho $42-43$. 
work for Georgia. Most of the ministers who went to the colony received in whole or in part support from it. Catechists were also maintained. In addition, the Society was instrumental in getting the Trustees to take a greater interest in the religious welfare of the province than they would otherwise have done.

Another society that did some missionary work in the colony was The Associates of the Late Rev. Dr. Bray. It was founded in 1733. Its purpose was to provide libraries for ministers at home and abroad and to carry on missionary work among negroes. Its name was taken from that of Dr. Thomas Bray, once a commissary of the Bishop of London in America, who had been so influential in arousing an interest in educational and evangelistic work. We have already noted his activity in the founding of other societies. The organization to commemorate his work did not carry on very extensive operations in Georgia. It equipped the pastor's home in Savannah with a very good library, and in the later years of the Trust it aided in some work among the negroes. ${ }^{4}$

The three organizations already mentioned were corporations independent of church control; but they were all affiliated with the Church of England. They all still exist and are doing good work.

Another agency of the home land that was active in Georgia was the Society in Scotland for Promoting Christian Knozoledge. It was affiliated with the Presbyterian Church; and it combined in its work the objects of all three English societies that we have been considering. Its principal activity in Georgia was the supporting of a mission among the Scotch who settled at Darien in the southern part of the province. ${ }^{5}$

'B. T., Ga., XI: Martyn to Ottolenghi, Jan. 23, 1752.

'Warneck-Hist. of Protestant Missions 68. 
The Bishop of London was an influential factor in the religious atfairs of several Ancrican colonies; and we should consider his relation also to the development of Gcorgia. The jurisdiction of the Bishop of London in colonial ecclesiastical matters had long been recognized before Georgia was settled; but it had usually rested on custom rather than on formal commission. It was he who usually licensed minister's and schoolmasters for service in America. He appointed commissaries to visit churches and missionaries, to supervise for the Bishop all religious affairs, and to make reports to him. Just prior to the founding of Georgia, the new Bishop of London, Edmund Gibson, had secured from the king a formal commission for the performance of these various duties for which his predecessors had only the authority of custom. ${ }^{6}$

When missionaries began to be sent to Georgia, there arose a controversy between Gibson and the 'Trustees as to the scope of his authority in the province. He claimed the right to license all ministers of the Established Church who preached in the colony. The 'Trustees objected to this on the ground that the removal of the missionaries would then be in the hands of other authorities than themselves, and they did not feel that this was wise. They argued that Georgia had been founded since his commission was granted, and that it therefore could not come within the scope of the authority given him. Bishop Gibson threatened to bring to trial in the courts the question of his rights, but the matter does not seem to have been carricd so far. ${ }^{7}$ As a matter of policy, the 'Trustees usually asked the Bishop to ordain their ministers, and he sometimes slipped into their hands his license without its being requested; but the Trus-

${ }^{6} \mathrm{New}$ York Colonial Docs. V: 849-85t.

${ }^{7}$ C. R. V: $46-48$. 
tees chose to ignore such actions on his part. ${ }^{8}$ The Trustees felt that Gibson was hostile to them, and they complained that he opposed at times their efforts to advance the spiritual welfare of Georgia; ${ }^{9}$ but the indications are that they misjudged his motives in such cases.

The Bishop of London did not appoint any commissary to look after ecclesiastical affairs in Georgia; but his representative in South Carolina, Commissary Alexander Garden, had a rather interesting encounter with Rev. George Whitefield, at the time an ordained minister of the Established Church and locited in Georgia. It is not within the scope of this chapter to gire a detailed account of the controversy ${ }^{10}$ but the leading facts may be briefly stated. Whitefield and Garden were for several years cordial and friendly; but when the former began to show signs of breaking away from the forms of the Church of England the Commissary reproved him and finally forbade him to preach in Charleston, where Whitefield was visiting. The latter disregarded Garden's warning and continued to preach; and he was accordingly brought to trial in the commissarial court at Charleston on July 15, 1740. Whitefield refused to answer the charges brought against him because he denied the authority of the court to try him. He declared that the Bishop of London could not establish in South Carolina competent courts without the consent and action of the colonial legislature. In the second place, he claimed that as a resident of Georgia he could not be tried in the court, even if it were a competent court for South Carolinians. Finally he asserted that the Trustees of Georgia, under whose exclusive

${ }^{8}$ C. R. V: 49.

${ }^{9}$ Ibid., 217 .

${ }^{10}$ For full and clear statements regarding the trial, see Cross $80-86$ and 'Tyerman's Whitefield I: 396-401. 
government he lived, doubted whether the Bishop of London had any jurisdiction in the colonies. ${ }^{11}$ After some delay Whitefield presented a formal paper refusing to aceept Garden as his judge; the latter declined to accept it, and Whitefield appealed to the English anthorities. 'The appeal seems never to have reached the proper persons, partly perhaps because the law was not at all clear as to who were to hear such appeals; and Garden finally summoned Whitefield to appear again in court for trial. The summons was ignored, and the Commissary pronounced a sentence of suspension from the ministry of the Church of England upon Whitefield. The latter utterly disregarded it, and the matter ended without further incident. It is of interest to us principally for the light which it throws upon the authority, or lack of it, of the Bishop of London in Georgia.

Having noticed brietly the other agencies or authorities that affected the religious history of the colony, we may now consider how the 'Trustees were prepared to deal with the subject and what were the results of their actions. The general Board was composed of men at first who were chosen on account of their religious or charitable proclivities. At later times, political influence came to be the prime factor in the choosing of Trustees; but nevertheless most of them were earnest Christians and were concerned about the spiritual development of the colony. Members of the Established Church were in the majority on the Board, and they were able to control in large measure the religious policy of Georgia ; ${ }^{12}$ but the Dissenters were very numerous, and many of them were quite influential. In spite of the differences in the faith of its nembers, the Board usually acted harmoniously on the various questions of religion that were

${ }^{11}$ Cross 82.

${ }^{12} \mathrm{C} . \mathrm{R}$. V : 116 et seq. 
presented to it.

As in all other matters concerning the management of Georgia, the Trustees were vested with full power in religious affairs, and they guarded jealously their authority, as in the controversy with the Bishop of London for example. They did not, however, desire seriously to restrict religious liberty in the colony. They proclaimed freedom of conscience in worshipping God to all persons except Roman Catholics, provided they should be content with the quiet and peaceable enjoyment of their religion without offense or scandal to the government. ${ }^{13}$ While almost all forms of worship were thus declared permissible, the Trustees after some opposition decided that it was incumbent upon them to furnish to the inhabitants of the province the gospel according to the forms and usages of the Established Church of England.

The Trustees had not planned to make such a provision for the Episcopal service at the beginning of the colonization; but a little more than a week before the first settlers sailed for Georgia, Dr. Henry Herbert met with the Board of Trustces and offered to go to the new colony and perform the religious duties needful without salary. His offer was promptly accepted; and he sailed with the first colonizing expedition to Savannah. ${ }^{14}$ It was understood that his appointment was to last for a single year. His stay in Georgia was only a few weeks in length, for he was taken ill and died on his return voyage to England. His work made no lasting impression on the settlement.

In the meantime, the Trustees were trying to arrange for a permanent missionary to Georgia. They appealed to the Society for the Propagation of the Gospel in Foreign

${ }^{13}$ C. R. $1: 21$.

${ }^{14}$ Ibid., 84-85. 
Parts for assistance in the finding and in the supporting of a suitable minister; but before the Society provided a man, Rev. Samucl Quincy applied to the Trustees for work and was accepted by them. ${ }^{15}$ He had good recommendations and gave promise of being a thoroughly satisfactory worker. The Society agreed to aid in his support if the Trustees would provide his expenses to Georgia and agree to furnish him with a glebe, looking to his permanent support as soon as the funds of the Trust would permit.

Quincy entered upon his duties early in May, 1733. Details as to his ministry are meager, but there is abundant evidence that he was not in harmony with the Georgia officials. He had serious quarrels with Thomas Causton, the first magistrate of the colony, and complained bitterly of the treatment received at his hands, speaking of him as an insolent and tyrannical bailiff. Quincy did not correspond with the Trustees or keep them informed as to the progress of his work; and Oglethorpe felt that he was not sufficiently diligent in the performance of it. ${ }^{16}$ He continued his pastorate for about two and a half years until the Trustces on October 10, 1735, revoked the lieense which had been granted him to serve as minister and appointed John Wesley to succeed him. ${ }^{17}$

It was not wholly Quiney's fault that he met with no better suceess in the colony. He was sick during a considerable portion of his stay in Georgia and had to supply his place with ministers from South Carolina. ${ }^{18}$ He found it difficult also to adapt himself to the frontier conditions that had to be faced in the new work. That he was an able and

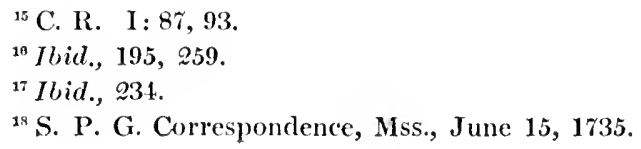


successful minister in other fields is fully established; for after leaving Savannah he went to South Carolina where he served most successfully churehes at Dorchester, Colleton, and Charleston. ${ }^{19}$

When Wesley volunteercd as a missionary to Georgia, he did not intend to act as minister for an established congregation, but he rather expected to labor for the conversion of the Indians. His commission from the Trustees made no mention of the work among the natives, merely giving him general license to exercise in Georgia the office of a priest of the Church of England; but he hoped nevertheless that he would be able to carry out his first cherished plans in the new colony. On reaching his chosen field of labor in February, 1736, he expressed to Oglethorpe a desire to proceed at once among the Indians, and a conference was held with some of them; but Wesley was told that the time was not ripe for the prosecution of such missionary enterprise, and at Oglethorpe's request he assumed the care of the Savannah mission.

At his new station he had charge of a group of about seven hundred persons, comparatively few of whom were regular communicants of the Church of England. He entered upon the duties of his office with zeal and enthusiasm, and he made a good impression. Wesley was delighted with the prospect, writing in his Journal, "O blessed place, where having but one end in view, dissembling and fraud are not; but each of us can pour out his heart without fear into his brother's bosom." 20 He exhibited in this early work something of the methodical tendeneics that afterward distinguished him; for he planned a systematic eampaign of religious instruction and Christian culture. Some of the more

${ }^{10}$ Dalcho 167, 349, 361.

${ }^{20}$ Wesley's Journal 29, 34, 41. 
earnest parishioners were organized into a sort of society for the purpose of reproof, instruction, and exhortation in the Christian life. From this group, he selected a smaller number for still more intimate discussion and study in his own home. In his Savannah congregation, his energies seem to have been centered largely upon the development of persons already professing Christians; but in his dealing with other persons he was distinctly evangelistic in his teachings. ${ }^{21}$

While all accounts agree that he was popular with the people and that his early efforts were appreciated, it was not long before he began to lose the esteem and confidence of many of them. There seem to have been several reasons why this was true. Strangely enough, in view of his later career, one of the principal charges against him was that he adhered too strictly to the literal requirements of the Established Church, without making due allowance for frontier conditions in the new province. Another source of dissatisfaction was his meddling in affairs with which he scemed to have no business, especially taking sides with certain malcontents in Savannah who were trying to overthrow the established rules of the Trustees. ${ }^{22}$ While these causes led to a certain amount of coolness toward him on the part of some of the leading members of his mission, they were not sufficient to drive him from the colony; and the immediate occasion of his leaving under very unpleasant circumstances was a quarrel with one of the leading families of the colony, growing partly at least out of a love affair.

When Wesley arrived in Georgia, he was welcomed freely into the homes of the leading people. Among those whom he frequently visited in a friendly way was Thomas Caus-

${ }^{21}$ Wesley's Iournal, 38, 48, etc.

${ }^{22}$ C. R. IV : 18-19. 
ton, the chief magistrate of the colony under the Trustees. In this home he became rather intimately acquainted with Miss Sophia Hopkins, a niece of Causton. He became much attached to her, and there seems to be no doubt that he wished to marry her; but the happy relations between them were suddenly broken up. The reason for this is not altogether clear. Wesley's friends assert that he was advised by Delamotte and his Moravian friends not to prosecute the suit and that his showing coldness toward Miss Hopkins resulted in a breach between them. Other accounts indicate that the young lady without provocation from him chose another suitor. At all events, she was married rather suddenly to William Williamson, a clerk in her uncle's store. ${ }^{23}$

However Wesley may have felt about the advisability of marrying Miss Hopkins himself, there can be no question that he was piqued at her sudden marriage to another. He soon had occasion to reprove her conduct in some small particulars, and hard feeling resulted on both sides. A few weeks later, he excluded her from the holy communion on rather technical grounds; namely, that she had not previously notified him of her intention to commune. ${ }^{24}$ While he was within his strict legal right in doing this, it was an ill advised act in the case of Mrs. Williamson, with whom his relations were already somewhat strained.

As a result of Wesley's refusal to allow her to partake of the Lord's Supper, suit was brought against him for damages to the amount of $£ 1,000$ by Mr. and Mrs. Williamson. The whole community was also plunged into a bitter controversy over the matter. The action brought was a civil one; but it was also planned to prosecute him as a criminal. At the next meeting of the grand jury, Thomas ${ }^{23}$ C. R. IV: 14.

${ }^{2+}$ Wesley's Journal 50 et seq. 
Causton as chief magistrate charged that body to investigate the complaints against the minister. It certainly was not a proper thing for Causton to press the case in person, for his close relation to Mrs. Williamson made it evident that he was not acting impartially. The friends of Wesley claimed that the jury was packed with his adversaries. ${ }^{25}$ Whatever the truth may be as to that, it considered the matter and reported adversely to him. 'Two reports were presented by the grand jury; the majority, consisting of thirty-two members, found a true bill against Wesley on ten counts as follows:

1. Speaking and writing to Mrs. Williamson against her husband's consent.

2. Repelling her from the holy communion.

3. Not declaring his adherence to the Church of England.

4. Dividing the morning service on Sundays.

5. Refusing to baptize Mr. Parker's child, otherwise than by dipping, except the parents would certify it was weak and not able to bear it.

6. Repelling William Gough from the holy communion.

7. Refusing to read the burial service over the body of Nathaniel Polhill.

8. Calling himself Ordinary of Savannah.

9. Refusing to receive William Aglionby as a godfather only because he was not a communicant.

10. Refusing Jacob Matthews for the same reason; and baptizing an Indian trader's child with only two sponsors. ${ }^{26}$

The minority report, made by twelve members, was not presented to the court, but it was forwarded to the Trustees as a protest against the injustice that was being done Wesley. It took up the counts in order and expressed the ${ }^{26}$ Wesley's Journal $55 . \quad{ }^{28}$ Ibid., 56. 
opinion that none of them were sufficient for the prosecution of the accused. ${ }^{27}$

Wesley himself demurred to all the counts except the first on the ground that they were strictly ecclesiastical and that the town court of Savannah had no authority to try such matters. He asked for inmediate trial on the only civil charge; namely, speaking and writing to Mrs. Williamson against her husband's consent. The court refused to give trial at that time, and it postponed the matter five or six times more at later meetings. In the meantime, the charges against him had been widely published in the papers of America. When Wesley found it impossible to vindicate himself in the colonial courts for lack of getting his case tried, there seemed to him no alternative but to try to clear himself before the Trustees.

On October 7, 1737, he consulted his friends about the advisability of leaving. He showed them that there was no possibility of instructing the Indians, the purpose for which he had come; that he had never engaged himself to the Savannah church, and that he was no longer acceptable to many of his parishioners there; and that he might do the colony real service by reporting to the Trustees the true state of affairs. ${ }^{28}$ His friends advised against immediate departure; but after he appeared at court twice more without securing trial, they agreed with him that it was time to leave the colony. He gave public notice of his intention and sent a special written notice to the magistrates. They refused to allow hin to leave, but they were not very zealous in their efforts to prevent his departure; and he went by boat to South Carolina on the night of December 2, 1737. ${ }^{29}$

${ }^{27}$ Wesley's Journal 57-58.

${ }^{28}$ Ibid., 59.

${ }^{2}$ C. R. IV : 36-37; Wesley's Journal 60-61, 
While many of the people of Georgia felt that Wesley was justified in leaving, other good men such as Secretary William Stephens regarded him as a fugitive from justice and thought that the manner of his departure was unworthy of him. ${ }^{30}$

On February 22,1738 , Wesley appeared before the 'Trustees and gave them an account of his troubles in Georgia, presenting also various certificates from his fricnds in the colony to substantiate his report. 'The 'Trustees were somewhat inclined to sympathize with him, and both Williamson and Causton felt compelled to excuse the parts they had played in the transaction. ${ }^{31}$ The records do not show that any formal action either of condemnation or of approval was taken; but on April 26,1738 , Wesley was allowed to resign the appointment that he had reeeived to do work in Georgia. $^{32}$

The career of Charles Wesley at Frederica was too brief to need extended comment. He reached St. Simons Island about the middle of February, 1736, and left in a little less than three months. He was aeting in a double capacity, as Secretary for Indian Affairs, and as chaplain for the military settlement at Frederica. The combination of eivil and ecclesiastical functions made his work difficult even if there had been no other handieaps; but within the first week of his labors he incurred the dislike of some of his parishioners. These made life miserable for him by tattling, and then succeeded in making even Oglethorpe suspicious of Wesley.33 He later regained in large measure the confidence and esteem of the General and of his other people ${ }^{80}$ C. R. IV : 40-41.

${ }^{81}$ B. T., Ga., IX: Verelst to Williamson, Dec. 14, 1737; C. R. V: 52,60 .

${ }^{32}$ C. R. I: 308, 315-316.

${ }^{33}$ Whitehead 72-80. 
at Frederica; but he was never able to be a really useful minister at that mission. In May, 1736, he left the town to attend to some civil business in Savannah, and he never returned. He wished to resign from his duties, but Oglethorpe requested that he continue for at least a while to hold the offices. In July, 1736, he was sent to England to carry dispatches. Sickness prevented his immediate return, and he finally surrendered his commissions both for civil and for ecclesiastical work. ${ }^{34}$

The failure of (harles Wesley was due to practically the same causes as that of his brother John. They were both young and inexperienced when they came to Georgia. They were so intent on religious matters that they gave little thought to practical affairs, while the communities in which they labored were so engrossed with the daily problems of life that they did not want as many religious demands as the Wesleys made. Both ministers were prone to censure snuall defects, and Georgia was not a place suitable for enforcing the strict letter of either the civil or the religious code. Each of them lacked tact and ability to deal with the varied types of human nature that he encountered in the colony. While they were failures in Georgia as ministers, their characters were pure and sincere. They were earnest Christians: and their later careers of usefulness and of greatness fully justify the claims of their friends that they did not have in Georgia a fair opportunity of showing their true worth.

Before John Wesley left Georgia, he had succeeded in getting George Whitefield interested in becoming a missionary in the colony. As early as June, 1737, special contributions were taken in England to enable Whitefield to go to his field of labor; and on December 21, 1737, he was ${ }^{34}$ Whitehead 82-83. 
formally accepted by the Trustees to serve at Frederica as a deacon of the Church of Lngland. ${ }^{35}$ He left the Downs for Georgia the day before John Wesley landed there on his return to England; but the transport on which Whitefield sailed was delayed and he learned of his friend's leaving Savannah. He immediately wrote from the ship asking the 'Trustees' advice as to the scope of his labors in Georgia in view of Wesley's absence; and they gave him authority to officiate both at Savannah and at Frederica or at either place. $^{36}$

Whitefield reached Savammah May 7, 1738. He at once began work in two departments. With the aid of Habersham he prosecuted educational interests, especially those of orphans; and at the same time he began active work in the Savannah mission field. His achievements in education have already been related. As minister in Savannah, he made a strong impression from the first. He conducted as many services as Wesley did, but the people did not complain of them. He held four on Sundays and three formal ones during the week, besides daily readings and expoundings in small groups or from home to home. Even those who like Secretary Stephens did not approve the doctrines taught by Whitefield received him cordially and were regular attendants on his services. ${ }^{37}$

During his first stay in Georgia, he confined his work very largely to Savannah, making only one brief missionary expedition to Frederica; but he was in the colony only a short while, leaving on August 28, 1738. He was criticised for his haste in returning so soon to England; but, as we have seen, his object was to prepare for better work in the colony

${ }^{\text {ss }}$ C. R. I: 304-305.

${ }^{\mathrm{a}}$ Ibid., 318.

${ }^{37}$ C. R. IV: 150, 157, 165, 191. 
by being ordained to the full priesthood in the Church of England and by preparing to carry on the orphanage work. He was cordially received by the Trustees, and they agreed to most of the proposals which he made. They had appointed a minister, William Norris, to succeed John Wesley as regular missionary at Savammah; but this station was assigned to Whitefield after he became a full priest, and Norris was sent to Frederica. ${ }^{38}$

It was more than a year after his appointment as pastor before Whitefield went to Georgia; and he was then too much occupied with orphanage affairs to give very serious attention to his duties as minister. During the period of his service on this occasion, he greatly shocked some of the more conservative members of the Established Church by extempore prayers, strong pleas for justification of faith only, and anathemas against those who did not accept the new doctrines. ${ }^{39}$

Whitefield was serving the Savannah people without pay, having offered of his own accord to do so; and he did not feel so much the responsibility of being regular in his ministry as he would otherwise probably have done. The irregularity of preaching soon had a bad effect on the congregation, for the attendance on divine services decreased rapidly. Whitefield suggested that he be allowed to supply a minister of his own choice to help him in the work, but the Trustees were afraid to risk that, especially as Whitefield was showing so many signs of being not fully orthodox. ${ }^{40}$ As we shall presently notice, he suggested to Rev. William Norris the plan of helping in the Savannah region in addition to the Frederica district, but the suggestion was

$$
\begin{aligned}
& { }^{38} \text { C. R. II : 259-260. } \\
& { }^{39} \text { C. R. IV : 504, } 538 \text {. } \\
& { }^{40} \mathrm{C} . \mathrm{R} \text {. V: 331, } 538 .
\end{aligned}
$$


not accepted. After his trial in South Carolina in the Court of Commissary Garden, Whitefield was supposed to be ineligible to preach in houses of worship of the Established Church; but we have already pointed out that he did not regard in the least the sentence of suspension against him, and there was no effort in Georgia to enforce it against him. He had been relieved by the Trustees of his duties as minister in Savannah before the sentence of Garden was passed, but they would probably not have been influenced by it even if it had already been passed. ${ }^{41}$

Mention has already been made of the appointment of Rev. William Norris as a minister for Georgia. He was informally selected at a meeting of the 'Trustees on June 28 , 1738, and was finally appointed on .July 12. He reached Savannah the following October just at the time when Causton was being displaced as a storekeper and when the prospects of the colony were darkest. His reception was not cordial. Oglethorpe intimated to him that he was not needed, as Whitefield was already the minister at Savamnah and Habersham had been appointed to read the service while the pastor was away. ${ }^{2}$ Habersham and other friends of Whitefield were open in their criticisms of Norris, possibly because they regarded him as trying to displace the former as minister. Secretary William Stephens seems to have been almost his only friend among the influential men. ${ }^{43}$ Norris himself was quick to take offense at criticisms, and his letters are full of complaints. He felt that Whitefield had resorted to unfair means to secure the Savannah appointment from the Trustees after it had been given to him, though there is no evidence to support him in this belief.

${ }^{41}$ C. R. I: 373 .

${ }^{42}$ I3. 'T., Ga., XXI: Norris to Verelst, Nov, 6, 1738,

${ }^{43}$ C. R. V: 73-74; C. R. IV: 215- 19. 
When Whitefield reached Georgia, he was at first very cordial to Norris, inviting him to his house and asking him to assist him in the Savannah work, as orphanage matters would require his own absence very frequently. ${ }^{44}$ Norris declined the offer on the ground that the Trustees had removed him from work in the northern part of the colony, assigning him to Frederica, and he felt that he ought to devote himself exclusively as they direeted; but he did remain in Savamnah for more than two months and rendered some assistance in religious affairs. However, the friendly relations between him and Whitefield did not long continue. The latter accused him of preaching false doctrine and declared that he would never permit him to officiate in his church again. He also accused him of playing cards when he ought to be engaged in ministerial work, and on that ground refused to let him partake of the sacrament. ${ }^{45}$

At Frederica Norris was cordially received by the inhabitants and was asked by Oglethorpe to serve as chaplain for the soldiers encamped there $;^{46}$ but his popularity was of short duration. He was soon accused of idleness and neglect of duty, and in a short while he was charged with gross immorality. These charges were never thoroughly established, but they were not satisfactorily disproved, and they ruined the prospects of Norris' usefulness in the community. ${ }^{4 \tau}$ In addition he alienated many of the officers of the regiment by lack of tact in dealing with them. About June 1, 1741, after a service in the town of little more than a year, he left for England. On his return to London, he made himself very obnoxious to the Trustees by giving the colony

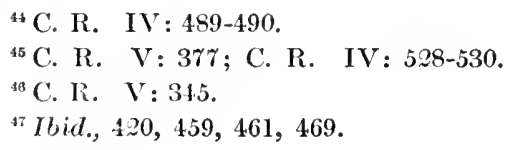


an evil report whenever he had an opportunity and by claiming that his salary had not been paid. For years he continued to be a source of expense and trouble to the 'Trust. ${ }^{4}$

When the Trustees revoked the commission of Whitefield on July $\%, 1740$, they thought that his place would be at once filled by Rev. William Metcalf, who had been highly recommended to then. He was duly commissioned for the Savammah work and he was long expected in the colony, but he died before he could enter upon his new duties. ${ }^{49}$

Rev. Christopher Orton was appointed to the Savannah field on September 1+, 1\%t1. He was a "good natured, harmless young man," who was not of age when first chosen by the Trustees. ${ }^{50}$ He did a valuable work in the colony for a few months. Conditions were very much disturbed on account of the Spanisl invasion, and there was not much heart for religion on the part of many people; but he looked after the outlying districts, revived the school work, and served Savammah faithfully. His work was cut short by a severe fever from which he never recovered, dying on August $12,17+2.51$

It was no easy matter to secure missionaries for the Georgia work, and it was nearly a year before the vacancy could be filled. After investigating the fitness of other possible workers, the Board of Trustees finally selected Rev. Thomas Bosomworth for the position. He had already lived in Georgia, having acted as clerk for Secretary Stephens and having also served in the army under Oglethorpe. He had not given promise of being especially religions, but

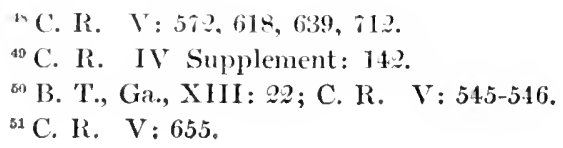


shortly before his appointment he had returned to England and taken orders. ${ }^{52}$ He was chosen for the Savannah mission; but he went instead to Frederica and began to assist as chaplain of the regiment until the Trustees learned of his change in plans and ordered him to follow his original directions. $^{53}$ He was a trouble maker all the while he was in the colony. He was a bitter enemy of the orphanage and, as we have seen, he wrote to the Trustees with a view to getting it suppressed. He continued in Georgia until $17+5$, when he left the province without getting leave from his superiors, the Society for the Propagation of the Gospel in Foreign Parts and the Trustees; nor did he make any provision for services to be continued in his absence. He explained to the Venerable Society that he found it necessary to leave the colony both for his own preservation and for the peace of the colony. He claimed that he and his Indian wife had not been treated well by the white people and that the Indiims were threatening to cause trouble out of sympathy for them. To avoid such evil consequences, an abrupt departure was his only recourse. ${ }^{54}$

The Trustees did not feel that his excuse was sufficient, and they addressed a letter of reproof to him and revoked his commission. Bosomworth later returned to the colony, though not as a minister; and he gave to the authorities of Georgia more real trouble and anxiety perhaps than any other person who ever resided there, for he succeded in stirring up the Creek Indians agalinst the colony. 'The efforts he made were purely selfish, and it was not his fault that they did not succeed.

The next appointee for the Savannah mission of the

${ }^{52}$ C. R. V: 630-631, 686, 704.

${ }^{33}$ C. R. I: 454 .

s. P. G. Correspondence, Mss., Sept. 3, $17 \notin 5$. 
Church of Fingland served longer and on the whole did better work than any of the men who preceded him. He was Rev. Bartholomew Zouberbubler who had been born in Switzerland, but was reared and educated in South Carolina. As early as 1741, the German inhabitants of Savannab had requested that he be allowed to supply them with preaching, as he could give them instruction in their own langrage. 'The request was granted by the 'Trustees, but there was no way of paying for his services at that time. ${ }^{55}$ Other requests had been made also for a minister who could speak both French and German." As Zouberbuhler could meet this requirement, and as he was ordained a priest of the Established church, the 'Trustees felt that he would be the very mim to meet the needs in Savannals; and he received his appointment Novcmber 1, 1745. ${ }^{57}$ He proceeded at once to Savannah and entered upon his duties. He was a zealous worker, preaching regularly in both English and German, holding frequent prayer services, and visiting all persons within a radius of six or eight miles from Savannah, whether or not they were nembers of his congregation. ${ }^{5 \mathrm{~s}}$

In spite of his earnest labors, Zouberbuhler did not supply all the religious work that was desired by the foreign speaking people of the vicinity. Those living in the little villages of Vernonburgh and Acton had petitioned the Trustees to allow a Swiss minister, Rev. John Joachim Zubli, to serve them; and he had actually entered upon the duties of the work before he leirned that the Trustees on account of the expense could not agree to his employment. In 1746 these people wrote the Trustees again, telling that they were trying at their own cost to provide a house of worship and asking once more that Zubli be appointed as min-
${ }^{55}$ C. R. VI: 17 .
${ }^{57}$ C. IR. II : 469.
${ }^{50} \mathrm{C} . \mathrm{R}, \mathrm{V}: 713-715$.
${ }^{59}$ B. T., Ga., XXIII: 23. 
ister. The Trustees desired to encourage the people in their efforts to help themselves, and so they wrote to Zouberbuhler recommending that he accept Zubli as his assistant and stating that if he would allow the assistant $£ 10$ annually from his salary they would give him an additional servant. ${ }^{59}$ To such an arrangement, Zouberbuhler was not at all willing to consent. He did not like Zubli, as he regarded him as an interloper in his parish; and he was not willing to surrender any part of his salary. On the contrary, he wrote the Trustees and also the Society for the Propagation of the Gospel in Foreign Parts that servants were an expense rather than an aid and that he did not have a sufficient income even without dividing with another. ${ }^{60}$

He was so much in earnest about the matter that he went to England to confer in person about it. He requested the Society to remove him to some mission in South Carolina where he might at least procure food and raiment, both of which he was in danger of lacking in Georgia. The Trustees appreciated his services so much that they were not willing to permit him to leave Savannah. As a result of several conferences with him, they agreed that if he would return to Savannah they would give him double the salary he had been getting, would provide him with two servants, would repair or rebuild the parsonage, would lay out the glebe in a better place, and would give to him and to each of his two brothers five hundred acres of land. ${ }^{61}$ More signal proof of their appreciation of him could hardly be given, for at this time the colony was in greater financial difficulties than at any previous time.

Encouraged by the consideration shown him, Zouberbuhler

${ }^{59}$ C. R. I : 492-493.

${ }^{80}$ S. P. G. Correspondence, Mss., Aug. 8, 1748.

${ }^{61}$ B. T., Ga., X: Martyn to Pres. and Assts., July 7, 1749. 
returned to his work and continued to perform faithfully his duties until the end of the proprietary period. The most notable event of his remaining ministry was the completion and dedication of the Savamah church, but this will be noticed later. When, in 1758, the royal province of Georgia was divided into parishes of the Church of England, Bartholomew Zouberbuhler was named Rector of Christ Church in Savannah, the prineipal church in the colony. ${ }^{62}$

The only other mission which the Established Church through its societies attempted in Georgia was at Augusta. Here the enterprise was begun on the initiative of the setthers themselves. 'They requested the Trustees to supply them with a minister, but the expiration of the period of the Trust was near at hand; and the Board felt that they would be unable to pay the salary of a missionary. However, as they had so frequently done before, they presented the petition to the Society for the Propagation of the Gospel in Foreign Parts with the request that it send a worker if possible. The people of Augusta promised to pay foO ammually toward the salary of a minister, to cultivate a glebe and build a parsonage for him, and to provide a handsome church, the building of which was alreaty considerably atranced. ${ }^{63}$ The Venerable Society finally agreed to the proposal on condition that the 'Trustees grant the glebe and that the people perform their promises. Rev. Jonathan Copp was the missionary selected. He was an American, a graduate of Yale, who had gone to England for ordination as deacon and priest because there were no bishops in the colonies. He reached Augusta in August, 1751, and was joyfully received. ${ }^{64}$

In spite of the cordial welcome given to the new minister,

es C. R. XVIII: 261 .

${ }^{33}$ S. I'. G. Correspondence, Mss., Aug. 8, 1751.

at Itid., Aug. 15, 1751. 
the work at Augusta did not prosper. Copp himself was partly to blame, for he had hardly begun his work before he stirred up disputes among his people; but they too were at fault. When they had secured a minister, they were not so enthusiastic in providing for him as they had been when they were trying to get him. The Trustees were too occupied with preparations for surrendering their charter to urge the people to perform their duty. Copp remained until after royal control was established in Georgia; but his letters to the Socicty abound with eomplaints and indicate fully his disappointment with the field of work to which he had been assigned. ${ }^{65}$

In addition to the work of the Church of England outlined in the preceding pages, its services were held irregularly for Oglethorpe's regiment. A Mr. Dyson acted as chaplain from its arrival until his death in 1739; but he was a drunkard and otherwise immoral, and his ministry only served to bring things religious into contempt. ${ }^{66}$ We have already pointed out that Norris served as elaplain for a while; and, though he baptized many soldiers during his ministry, he was soon diseredited. Other men followed him for short periods, but none of them accomplished enough for us to consider them here.

On the whole, one cannot help joining in Copp's feeling of disappointment as he reviews the work of the Established Chureh in Georgia. Only two or three centers were reached at all, and the efforts in them were too spasmodic to hope for much suceess. It was the favored religion of the Trustees, and they regretted that it did not reach effectively more of the colonists. If the Trust had lasted longer, it is probable that more systematic efforts would have been ${ }^{65}$ S. P. G. Correspondence, MIss., 1751-1752; B. T., Ga., XXIV: 93-94.

${ }^{\infty}$ C. R. IV: 198 ; C. R. V: 80. 
adopted to cover the whole province with the influences of the Church. In 1751 Zouberbuhler suggested accomplishing this object by the establishment of a system of itinerant catechists; but there was no time for the 'Trustees to try the experiment, and notling came of it. ${ }^{67}$

The next religious work in Georgia that we shall notice was that done under Presbyterian auspices. In 1735 the Society in Scotland for Promoting C'hristian Knowledge notified the Trustees that it would support a missionary to labor among the Scotch going to Georgia if the authorities controlling the colony would license him. On August 23, of the same year, Accomptant Verelst wrote for the 'Trustees that they heartily approved of having a Presbyterian go to the field suggested, and they asked the Society to nominate a man, promising to appoint him as a minister for the colony and to provide for him a glebe of three hundred acres. ${ }^{68}$ In response to this letter, the Society named Rev. John MeLeod who had just been ordained a minister of the Presbyterian church, and on Oetober 29,1735 , he was regularly commissioned by the Trustees for the performance of ecclesiastical duties in Georgia. ${ }^{69}$

McLeod settled at Darien and labored among the Scotch of that region for about six years. For a while he seemed quite successful and was highly regarded by the people in all parts of the colony, and the state of religion at Darien was repeatedly reported as excellent. ${ }^{\circ 0}$ He felt very keenly the need of a house of worship, and he worked earnestly to secure it. In 1738 he wrote to his supporting Society that the Trustees could not furnish the money for a church be-

${ }^{67}$ S. P. G. Correspondence, Mss., Aug. 15, 1751.

as 13. T., Ga., VIII: Verelst to S. P. C. K., Aug. 93, 1735.

${ }^{69}$ B. 'T., Ga., XII : 268.

${ }^{70}$ B. 'T., Ga., XXI: Stephens to Trustees, May $27,1738$. 
cause they were supporting too many schools, but he reported that Oglethorpe was trying to provide the needed funds. ${ }^{71}$

In the matter of securing a house of worship, the Scotch were disappointer ; and by 1740 McLeod seemed particularly discouraged on account of the loss of many of his parishioners who perished during the invasion of Florida. He resented also the rather strict rules, as he thought, that Oglethorpe had placed on the methods by which the Scotch might make their living. In May, 1741, he left Darien and soon took charge of a church in South Carolina. He wrote very severe letters to the Socicty about conditions in Georgia. The information he sent was so despondent that the Scotch Society determined to support no further work in the colony. ${ }^{72}$ McLeod could not justly be censured for leaving his Georgia work if he desired to go elsewhere; but there was no occasion for trying to injure the colony by misrepresentation. The Darien work suffered for lack of a leader, and it never again amounted to much.

There seem to lave been no other regularly commissioned Presbyterian ministers in the colony. At Bethesda there were quite a number of Presbyterian adherents, and Rev. Jonathan Barber, who acted for Whiteficld in spiritual matters during the latter's absence, was of that faith. He preached for the orphan community and occasionally in Savannah; but he was in the colony rather by the sufferance of the Trustees than by their appointment or that of any of the regularly organized missionary societies. ${ }^{73}$

The stay of the Moravians in the colony was too brief to require any detailed account of their religious history in

${ }^{71}$ B. T., Ga., XXI: Mcleod to S. P. C. K., Jan. 6, 1739.

${ }^{2}$ C. R. V: 589, 600 .

${ }^{73}$ C. R. IV : 52, 116, 157. 
Georgia. Their object in coming to the province was twofold-to secure an asylum from the persecutions at home and to do missionary work among the Indians. 'The first group of them came to Georgia in the spring of 1735, setthing in Savannalı until they could clear and improve their lands on the Ogeechee river. This party was under the spiritual guidance of Rev. Augustus Gottlieb Spangenburg. They were joined by others who came under the leadership of Rev. David Nitschman during the following year. From time to time other small parties joined the colony, especially in 1738 when Rev. Peter Boehler led a small party to the colony and assumed the leadership of the whole Moravian community. ${ }^{\text {it }}$

They were a very industrious people. Their lands were cultivated better than those of any other settlers in the province, and they were soon able to repay the Trustees for their passage money which had been advanced to them, a precedent which few of the other colonists followed. They were the only settlers coming to Georgia during the period of the Trust who became entirely self-supporting.

The Moravians through their leader, Count Zinzendorf, asked to be appointed by the 'Trustees as regular missionaries to the Indians; but this request was declined on the ground that it would seem to be a reflection on England, as if there were not enough good men in it to preach the gospel to the natives. ${ }^{75}$ The Trustees, however, heartily approved of any missionary work that the Brethren on their own initiative and at their own expense might undertake. A most useful work was begun by them at Irene, about five miles from Savamnah, as we have already noticed. The policy of living among the Indians and adopting to a

"Loskiel, Part II: 3.

${ }^{75}$ 13. 'T., Ga., IX: Martyn to Zinzendorf, Sept. 23, 1737. 
large extent their customs and habits seemed to please the natives and made them more amenable to religious influences. There is every reason to believe that the mission would have made a permanent impression on the Indians if the Moravians had continued in Georgia. ${ }^{76}$

It was against the religious principles of the Brethren to bear arms in warfare, and the necessity of their having to do so in Georgia was one of the points discussed before they sailed from England. It was difficult for the 'Trustees to make an exception of them in the general rule that all men were liable for service without breaking down their whole militia system; but as the Moravians went to Georgia as servants of Count Zinzendorf, and not as independent frecholders, it was at last agreed that regular military service would not be required of then. It was specificd, however, that they would be required to furnish two men for guard duty, one for each of the Moravian plantations held in the C'ount's name. This arrangement was not altogether satisfactory to the Brethren, but they agreed to it. ${ }^{77}$

The authorities in the colony did not understand this exemption; and when the Spanish threatened to invade the colony, the Moravians were requested to furnish their quota of soldiers for defense. The latter declined the call and referred the matter to the Trustees, who of course upheld their former agreement; but the people of Georgia felt that the Brethren did not show the proper spirit and that the Trustees favored them too much. The Moravians realized the feeling on the part of the other colonists, and they felt that it would be best for them to move to some other location. Accordingly some of them left for Pennsylvania in

${ }^{\pi 6}$ Loskiel, Part II : 3-4.

${ }^{77}$ B. T., Ga., IX: Martyn to Zinzendorf, Sept. 23, 1737. 
1738, and the remainder departed in 1739 and in $1740 .^{78}$ Some attempt was made by Whitefield to get them interested again in missionary work in the province, but the results were negligible. ${ }^{7 !}$

Another religious work that was carried on in the Savannah region was that of the Jews. 'That there were any of them in Georgia was contrary to the wishes of the Trustees, who feared that their presence would prejudice the people of England against the colony. 'The manner in which the Jews were able to go to Savanmah against the wishes of the Trustees was as follows. When the Georgia enterprise was first launched, many people of England asked permission to help raise funds for its promotion; and of course the Trustees welconed such assistance. Among those who asked permission to solicit funds were three Jews, and they were readily allowed to do so. Instead of turning the money raised over to the Trustees, they used it in sending forty Hebrews to the colony as settlers. The latter arrived at Savammah during the summer of 1733. Oglethorpe found them useful citizens and made them welcome in spite of the efforts of his fellow 'Trustees to have them sent away from the province. ${ }^{80}$ As a matter of fact, they made very good citizens. 'They were too few in number to have a complete religious organization; but they rented a synagogue and conducted services regularly without the assistance of a rabbi. ${ }^{\text {s1 }}$ They were not propagandists, and their work was too quietly carried on to make much impression on the life of the community.

Another missionary enterprise that was begun at Savan${ }^{7}$ I oskiel, Part II: 5.

Io Ibid., 6-7.

si B. 'T., Ga., VIII: Martyn to Oglethorpe, Oct. 18, 1733, and Nov. 22, 1733.

${ }^{81}$ Stevens I: $368-369$. 
nah but never produced enough fruitage to require serious attention was an effort to organize a French mission. The work was carried on from Purysburg, South Carolina, by a minister named Chiffelle. He succeeded in gathering a following of about thirty persons and kept up the work for a year or two, but he could not get enough financial support to continue his efforts. So far as can be ascertained, he was not working under the auspices of any board or society in his efforts. ${ }^{\mathrm{s} 2}$

The last religious work for us to consider was the most permanent and successful done in the colony. It was that done among the Salzburghers. These were Lutheran Protestants who had been expelled by the Catholic clergy from the Bishopric of Salzburgh in Austria. They were sent to Georgir by Rev. Samuel Urlsperger, bishop of Augsburgh, and Mr. Chretien de Munch, a banker of the same place. Both these men were non-resident Trustees of Georgia, given this honor because of their activity in behalf of the persecuted Protestants. ${ }^{83}$ The Society for Promoting Christian Knowledge of England co-operated with the Trustees in removing the Salzburghers to Georgia, paying most of the transportation charges and contributing also to their maintenance. In the perfecting of the plans for the removal, James Vernon was more active than any of the other Trustees; and without his earnest negotiations first with the Protestants in Germany and then with the Society in England, the project could hardly have succeeded. ${ }^{84}$

On the first expedition to Georgia, some seventy-eight persons left Augsburgh; and the number was increased by others at Rotterdam. They were under the guidance of Baron Von

${ }^{82}$ B. T., Ga., XXII: 108.

${ }^{83}$ C. R. I: 499.

${ }^{84}$ Ibid., 69, 77, 78, 92, 93, etc. 
Reck; but they had as pastors Rev. John Martin Bolzius, who had been superintendent of the Iatin Orphan School at Halke, and Rev. Israel Gronau, who had been a tutor in the same school. ${ }^{85}$

'The colonists settled about twenty-five miles from Savannah in what is now Effingham County, Georgia. The site was chosen by their leaders in company with Oglethorpe. 'The town that was erected was called by them Ebenezer. In 1735 and again in 1\%36, other Salzburghers joined them, so that the total number in the latter year was about two humdred. 'The location which pleased them at first did not prove to be altogether suitable for a permanent home; and during the years 1736-1737 they moved to the Savannah river and established another town called New Ebenezer about the same distance from the town of Savanmah as their old settlement had been. ${ }^{\text {sf }}$ When the old town was completely abandoned, the new settlement was called simply Ebenezer as the first had been named. It was the chief center of Salzburghers in the colony, though in 1736, a smaller number of them had gone to settle with Oglethorpe at Frederica, and a smaller group still was located at Savannah.

From a religious viewpoint, Ebenezer was a mission station under the joint control of the English Society for Promoting Christian Knowledge and the German Evangelical Lutheran Church. All the pastors and people had to subscribe to the Augsburgh Confession and a code of rules drawn up in 1633 by Samuel Urlsperger of Augsburgh, Frederick M. Ziegenhagen of London, and G. A. Franké of Halle. According to these rules, at least seven deacons must assist the pastors in the discipline and financial manage-

s5 Strobel 51, 62.

${ }^{86}$ Ga. Hist. Collec. III: 13. 
ment of the church, and the people were to support the churches and schools if possible, though the salaries of pastors would be paid from England. ${ }^{87}$ Regular reports were required to be sent from the mission to Augsburgh and Halle in Germany, to the Society in London, and also to the Trustees. ${ }^{88}$

The Ebenezer congregation was ministered to by Rev. John Martin Bolzius until the period of the proprietors ended. He was an able and versatile man, being the leader of his people in things temporal as well as in those spiritual. He superintended agricultural pursuits, directed a corn mill and saw mill, supervised the culture of silk, and sold the products of these industries. He acted as arbiter in disputes, exercised supervisory care over the schools of the community, and managed the Ebenezer orphanage. In addition he kept up a rather vigorous correspondence with both England and Germany. For about ten years after the Salzburghers came to Georgia, Rev. Israel Gronau assisted Bolzius, especially in the religious affairs of the settlement. His work was largely confined to the outlying plantations. He was in every way a faithful preacher, and he was greatly beloved. He died in $1745 .^{89}$

After the death of Gronau, Bolzius with remarkable humility asked that a chief minister be sent over and that he himself might be the assistant; but neither the Lutheran Church authorities, nor the Trustees of Georgia, nor his own people, would have been willing for that. On November 11, 1745, Rev. Herman Henry Lembke ${ }^{90}$ was conmissioned by the Trustees to take the place of Gronau. He

${ }^{87}$ Strobel 93-99.

${ }^{89}$ Ibid., 106.

${ }^{89}$ Hazelius 61-62.

${ }^{\infty}$ C. R. II: 419. The name is here spelled Leruke, evidently an error. 
was well liked also both by his parishioners and by Bolzius. $^{91}$

Under the ministration of Bolzius and Lembke, the number of Salzburghers and their friends increased until two plantation missions were necessary besides the main station at Ebenezer itself. In 1751 another group of colonists made a fourth station necessary. By 1752 the number of settlers was so large that a third minister, Rev. Christian Rabenhorst, was sent to assist Bolzius and Lembke. The Salzburgher pastors did not at first feel that the new helper was needed, and they were not disposed to give him a cordial welcome; but he was a good man, and he soon won a place in the affections of both them and the people. ${ }^{92}$

The group of Salzburghers at Frederica did not get much religious attention. For a very short while, Rev. Joln Ulrich Driesler did excellent service and gathered a congregation of sixty-two members; but he died in 1744 , and his place was never filled. ${ }^{93}$

The Salzburghers at Savannah had no regular spiritual supply until Zouberbuhler went to that place. Occasionally services were held for them by ministers from Ebenezer or from Frederica; and Rev. John Joachim Zubli, as we have noticed, preached for them without a license from the Trustees for a short while. The latter gathered a congregation of about twenty member's; but when he could not get a salary fixed he removed to South Carolina. ${ }^{94}$

The success of religious efforts among the Salzburghers when they had largely failed among other people is a matter that may demand some explanation; and some reasons

"Hazelius 64-65.

"Strobel 13\%.

${ }^{\mathrm{n}}$ 13. T., Ga., XXII : 160.

3. 'T., Gat., XXIII: 15. 
for it may be given. They were religiously inclined by nature. They had recently been called on to suffer for their convictions, and therefore their principles meant much to them. Their religious life was earefully planned for them from the home bases, and reports were constantly required, so that regular advice and suggestions could be sent both from England and Germany. Their pastors were remarkably spiritual leaders; and the ministry of Bolzius was continuous throughout the period, while both Gronau and Lembke had fairly long terms of labor. The Salzburgher community had a uniform faith and was not troubled by the jealousy and bickerings of contending religious factions.

Having followed in some detail the work at various mission stations, we may next consider some general phases of the religious development of the colony as a whole. It is of interest to note the amounts of money collected and expended by the Trustees for the various religious purposes in Georgia. It is noteworthy that there were no contributions made by the public during the last eleven years of the Trust; interest in the charitable and missionary aspects of the new colony had died out except in the regular socicties organized with these ends in view. The contributions made during the first nine years may be grouped as follows: (1) For building churches about $\mathfrak{f} 702$; (2) For Indian missions about $£ 679$; and (3) for general religious purposes a little more than £522. Every penny of the contributions made was spent for the purposes designated; and for the building of churches, the Trustees had to draw from their own funds nearly $£ 100$ in order to supplement the amount donated by the public. All of the money contributed for the Indian work was expended almost as fast as it was received, and therefore the Trustees were unable to do anything for the natives in a religious way during the last ten years of 
their control. Most of the money for churches and about half of that for general purposes was spent during the later years of the Trust.

The funds just mentioned were those only that were furnished by the general public. 'They do not include the money sent by the various societies or agencies which really constituted the major part of the assets for religious development. During the twenty years of proprietary control, these organizations must have spent between $\mathfrak{f 3 , 5 0 0}$ and $£ 4,000$ for salaries alone. Besides, the Trustees probably expended from their own funds half this sum in furnishing servants and supplies for the workers in various centers. The total expenditures directly for religious purposes would therefore not be far from $\mathfrak{f} 7,500 .^{95}$

The salaries of none of the ministers were large. The usual sum paid by the missionary societies was $\mathfrak{f 5 0}$ annually. They required that this be supplemented in some way. The 'Trustees generally furnished the missionary with a house, a glebe of three hundred acres, and a few servants to cultivate the land. The King and sometimes other authorities or ageneies usually helped slightly each new missionary of the Established Church. ${ }^{96}$ It has already been pointed out that on aceount of his valuable services Zouberbuhler was made an exception in the matter of salaries and that he received nearly double the usual amount.

Few church buildings were put up in Georgia during the period of our study. There was great interest in securing a place of worship in Savannah, and contributions for the purpose were received the first year and for several years

${ }^{95}$ Specific references cannot be cited for these figures. They are collected from C. R. III, all of which is devoted to the receipts and expenditures of the Trustees.

${ }^{83}$ C. R. III: 87. 
following; but there was great delay in beginning the work. The structure first used at Savannah for church services was a tabernacle of rough boards. Its dimensions were only twelve feet in width and thirty-six in length; but when a court house was erected in the town, it was used also for the public worship. During the years 1735-1738, considerable sums were donated for the building of the church, and in 1737 some materials were sent from England with which to actually begin the erection of the structure; but that was the extent of operations at that time. ${ }^{97}$ In 1740 Whitefield offered to take charge of the enterprise, and he was given permission to proceed with it; but he was limited to $£ 300$ for the completion of the work, and he thought that sum too little for a beginning to be made. ${ }^{98}$

It was the 28th of March, 1744, before the work on the Savannah church really began. On that date the foundation was laid amid great rejoicing; ${ }^{99}$ but only the roof, floor, and framework were completed before the funds available for the work were exhausted, and the construction came to a close in the summer of $1745 .{ }^{100}$ Nothing further was done until the spring of 1747 when the Salzburghers were asked to get out at their mill sufficient lumber to complete the church. Bolzius wrote that he would cheerfully furnish the materials, but that he feared the shell of the building was already too rotten for completion. ${ }^{101}$ However, the work proceeded with more or less interruptions until it was ready for dedication on July 7, 1750. That particular day was chosen for the dedicatory exercises because it was the anniversary of two great occasions in the history of the colony,

${ }^{87}$ C. R. III : 170.

${ }^{\text {os }}$ B. T., Ga., IX : Verelst to Whitefield, June 11, 1740.

${ }^{80}$ B. T., Ga., XXII : 164.

${ }^{100}$ Ibid., 196.

${ }^{101} \mathrm{~B}$. T., Ga., XXIII: 36. 
the establishment of the first regular civil government seventeen years before, and the repulse of the Spanish at Frederica eight years previous. 'The setting apart of the new church, so long desired and needed, was a fitting accompaniment in the religious sphere of the other notable events in the civil and in the military life of the colony. ${ }^{102}$

'The church itself was large and beautiful, at least in comparison with other structures in Georgia. Its foundations were of stone; the outside of the building was finished with cement set off in initation of stone; and the insicle was plastered in white. Its windows were of crown glass sent especially from Fingland. The total cost of the building was more than double the original estimate; and even after the dedication $t 100$ more had to be spent to prepare the church for permanent use. ${ }^{103}$

The other houses of worship in the colony were not nearly so pretentious as that in Savamah, and comparatively litthe time was spent either in plaming or in erecting them. At Frederica a little chapel was built in 1739. It was sixty feet in lengtl and twenty feet in width. The lumber for it was cut and sawed by 'Trust servants, and much of the work in building was done by them so that the money cost

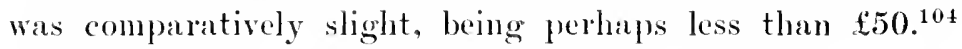
At Augusta "a handsome church" was erected when a call for a missionary was lodged with the Trustees, but it was little more than an inexpensive chapel. ${ }^{105}$

'The Salzburghers erected three churches. For some time after they settled at Ebenezer they worshipped at the orphanage which the 'Trustees had helped them erect; but ${ }^{1112}$ B. 'T., Gil., $\mathrm{XXI}^{r}: 5$.

${ }^{1113}$ C. R. V1: 188-189; C. R. 111: $16 \%$.

${ }^{11 '}$ C. K. $V^{\prime}: 96,348$.

wat '. l'. G. Correspondence, Mss., Aug. 8, 1751; B. T., Ga., XXIV: 93-91. 
finally with the aid of the German Lutheran church they built at Ebenezer a house of worship which they named "Jerusalem." Four miles away for the benefit of those living on plantations another was erected and called "Zion." In 1751 another was found necessary for the increasing plantation settlements, and it was called "Bethany." 106 All these houses were well built wooden structures. The materials used in them were largely those which the Salzburghers produced in their own saw mill. The inside of each church was painted, and the outside was treated with turpentine to prevent decay. ${ }^{107}$

The Moravians, the Scoteh, and the Jews had no structures worthy of the name exclusively for religious purposes. They either used public buildings or rented rooms for their services.

In attempting to sum up the religious efforts in Georgia, we should possibly except the Salzburghers and the Moravians from the general conclusions as to the other work. The Salzburgher religious conditions were almost above reproach; and the Moravian conditions were also excellent, though the pcople stayed in the colony too short a time for them to exercise much influence outside their own membership. With the exceptions noted, the religious work of Georgia resulted in much the same way as all the other undertakings in the province-executive, legislative, judicial, financial, and educational-that we have considered in previous chapters. It was characterized by earnest efforts and fond hopes on the part of the Trustees; by indifference on the part of most of the inhabitants of the colony; by ineffectiveness on the part of nearly all the officers or agents employed; and by general disappointment on the part of all concerned in the results

\footnotetext{
${ }^{100}$ Strobel 120-121.

${ }^{107}$ B. 'T., Ga., XXIII : 60.
} 
attained. The Trustees from the very beginning of their enterprise were largely moved by the charitable and religious aspects of the work to be done, and there was nothing in which they rejoiced or sorrowed more than in the good or evil reports that came to them regarding the progress of religion in Georgia. Most of the colonists felt that they had no time for church affairs. The struggle for existence and the various disputes that arose in the province preoccupied their minds. With some of them at least, the only reaction which they felt toward religion was the desire to criticise it. As a rule, the clergymen and catechists sent to Georgia were very young, just ordained for the ministry; and they were not accustomed to the wilderness ways. It was too much to expect that they could be very effective leaders. Many of them in later life became very strong men, much more so than their careers in Georgia would have indicated. Others of the ministers were men of low moral life, and they ought not to have been in religious work of any kind. With the coming of royal government, firmer religious organization, and a better class of settler's, the ecclesiastical conditions of the province materially inproved. 


\section{BIBLIOGRAPHY}

MANUSCRIPT ARCHIVES

Original Papers consisting of letters, memorials, and other communications from persons in America to the Trustees. 1738-1752. British Public Record Office, Board of Trade, Georgia, Vols. 21-24.

Entry Books of the Trustees consisting of letters and other correspondence sent by them to persons in Ameriea, Germany, and England. 1732-1752. British Public Record Office, Board of Trade, Georgia, Vols. 8-11.

Entry Books of commissions, powers, instructions, and leases issued by the Trustees. 1732-1752. British Public Record Office, Board of Trade, Georgia, Vols. 12-13.

Original Papers consisting largely of memorials and orders regarding the colony gathered from the various executive offices in England. British Public Record Office, America and the West Indies, Vols. 24-26, 535.

Journal of the Board of Trade, Vols. 45-47. British Public Record Office.

Original Papers consisting of reports and orders bearing on the relations between South Carolina and Georgia and on Indian relations. British Public Record Office, Board of Trade, South Carolina, Vols. 9 and 26.

Original Papers consisting of letters and petitions sent by persons in South Carolina, Georgia, and England to the Board of Trade and to the Secretary of State on matters pertaining to Georgia. British Public Record Of- 
fice, Board of 'Trade, South ('arolina, Vols. 5, 6, 8, and 14; and A. IV. I., Vol. 19.

Correspondence of the Society for the Propagation of the Gospel in Foreign Parts. 1732-1752. The transcripts bearing on the subject belong to Prof. H. L. Osgood, C'olumbia University, New York.

\section{PRINTED SOURCE MA'TERIAL,}

The Colonial Records of the State of Georgia. Edited by Allen D. Candler. Compiled and published by order of the legislature of Georgia. Atlanta, 190\$-1913. Vols. 1-22.

The Charter of the Colony. (C. R. I :11-26.

By-Laws and Laws Adopted by the Trustees. C. IR. I :31-62. Journal of the Trustees. C. R. I :63-5\%8.

The Minutes of the Common Council of the Trustees for Establishing the Colony of Georgia in America. C. R. II : $1-525$.

The General Account of All Monies and Effects Received and Expended by the Trustees for Establishing the Colony of Georgia in Ameriea. C. R. III:1-36\%.

Stephens, William. A Journal of the Proceedings in Georgia beginning October 20, 1737. C. R. IV:1-662 and the Supplement to Vol. IV.

Proceedings of the President and Assistants for the Colony of Georgia from Oct. 12th, 17+1, to Oct. 30th, 1754. C. R. VI: $1-461$.

Journal of the Earl of Egmont, first President of the Board of 'Trustees, from June 14, 1738, to May 25, 1744. C. R. $V: 1-724$.

Collections of the Georgia Historical Society. Vols. I-IV. Savannah, 1840, 1842, 1873, 1878. 
A New and Accurate Account of the Province of South Carolina and Georgia, with many curious and Useful Observations on the Trade, Navigation and Plantations of Great Britain, compared with her most powerful Maritime Neighbors in Ancient and Modern 'Times. London, 1733. Ga. Hist. Collec. I 442 et seq.

Reasons for Establishing the Colony of Georgia, with Regard to the Trade of Great Britain, the Increase of our People, and the Employment and Support it will accord to Great Numbers of our own Poor, as well as foreign persecuted Protestants. With some account of the Country, and the design of the Trustees. London, 1733. Ga. Hist. Collec. I.

Moore, Francis, A Voyage to Georgia Begun in the Year 1735. London, 1744. Ga. Hist. Collec. I: 79-152.

A New Yoyage to Georgia by a Young Gentleman, Giving an Account of his Travels to South Carolina and part of North Carolina, To which is added, A Curious Account of the Indians by an Honorable Person and a Poem to James Oglethorpe, Esq., on his Arrival from Georgia. London, 1737. Ga. Hist. Collec. II : 37-66.

An Impartial Inquiry into the State and the Utility of the Province of Georgia. London, 1741. Ga. Hist. Collec. I : 153-202.

Stephens, William, A State of the Province of Georgia Attested upon Oath in the Court of Savannah, November 10, 1740. London, 1742. Ga. Hist. Collec. II: 69-85.

A Brief Account of the Causes that have Retarded the Progress of the Colony of Georgia; Attested upon Oath. Being a Proper Contrast to "A State of the Province of Georgia Attested upon Oath" and Some Other Misrepresentations on the Same Subject. London, 1743. Ga. Hist. Collec. II : 87-168. 
Tailfer, (Pat., M. D.), Anderson, (Hugh, M. A.), Douglas, (Da.) and Others, A. True and Historical Narrative of the Colony of Georgia, in America, from the first Settlement thereof until this present Period: Containing the most Authentic Facts, Matters, and Transactions therein; 'Together with His Majesty's charter, Representations of the People, Letter's, etc, and a Dedication to his Excellency General Oglethorpe. Charleston, 1741. Ga. Hist. Collec. II : 163 et seq.

Martyn, Benjamin, An Account Showing the Progress of the Colony of Georgia, in America, from its First Establishment. London, 174.2. Ga. Hist. Collec. II : 265-310.

A Description of Georgia by a Gentleman who has Resided there upwards of Seven Years, and was one of the First Settlers. London, 1741.

Oglethorpe, James, Letters to the Trustees and Others. October, 1735, to August, 1744. Ga. Hist. Collec. III: 1-151.

The Castle-Builders; or the Mistory of William Stephens, of the Isle of Wight, Esq., Lately Deceased. A Political Novel, never before published in any language. (Supposed to have been written by 'Thomas Stephens.) Second edition. I.ondon, 1759.

South Carolina Historical Society Collections, Vol. IV. Charleston, 1887.

Massachusetts Historical Society Collections, Second Series, Vol. II.

Calendar of State Papers, Privy Council, 1732-1742. Cobbett, Parliamentary History of England. London, 1813. 'The period from 1735 to 1752.

Gentleman's Magazine or Trader's Monthly Intelligencer. London, 1731-1752.

London Magazine and Chronologer, 1740-1743. 
Carroll, B. R., Historical Collections of South Carolina. 2 Vols. New York, 1836.

Political State of Great Britain. July, 1\%32, to December, 1740. Volumes 44-60. London. ('Twelve of these volumes have references to Georgia.

\section{SECONDARY AUTHORITIES}

Adair, James, The History of the American Indians; particularly those nations adjoining the Mississippi, east and west Florida, Georgia, ete. London, 1775.

Brooks, R. P., History of Georgia. Boston, 1913.

Bruce, Henry, Life of General Oglethorpe. New York, 1890. Burke, Edmund, An Account of the European Settlements in America. 2 vols. London, $175 \%$.

Chalmers, George, Opinions of Eminent Lawyers on various points of English Jurisprudence, chiefly concerning the Colonies, Fisheries and Commerce of Great Britain. Burlington, 1858.

Cooper, Harriet C., James Oglethorpe, the Founder of Georgia. New York, 1904.

Dalcho, Frederick, An Historical Account of the Protestant Episcopal Church in South Carolina, from the first settlement of the Province to the War of the Revolution: With notices of the present state of the Church in each parish; and some account of the Early Civil History of Carolina never before Published. Charleston, 1820.

Dictionary of National Biography.

Doyle, J. A., English Colonies in America. 5 vols. New York, $190 \%$.

Evans, Lawton B., A History of Georgia for Use in Schools. New York, 1906. 
Fitchett, W. H., Wesley and His Century. A Study in Spiritual Forces. London, 1906.

Fries, A. L., The Moravians in Georgia. Raleigh, N. C., 1905.

Greene, E. B., The Provincial Governor in the English Colonies of North America. Harvard Historical Studies, Vol. VII. New York, 1898.

Harris, 'T. M., Biographical Memorials of James Oglethorpe. Boston, $18+1$.

Hawkins, Ernest, Historieal Notices of the Missions of the Church of England in the North American Colonies, previous to the Independence of the United States; chiefly from mss. documents of the Society for Propagating the Gospel in Foreign Parts.

Hazelius, Ernest L., History of the Amcrican Lutheran Church. Zanesville, Ohio, $18+6$.

Hewatt, Alexander, An Historical Account of the Rise and Progress of the Colonies of South Carolina and Georgia. 2 vols. London, 1779. (In Carroll's Historical Collections.)

Jones, Charles C., Jr., The History of Georgia. 2 vols. Boston, 1883.

The Dead Towns of Georgia. Savannah, 1878.

Tomo-chi-chi: Mico of the Yamacraws. Albany, New York, 1868.

Knight, L. L., Reminiscences of Famous Georgians. Atlanta, 1907-1908. 2 vols.

Georgia's Landmarks, Memorials, and Legends. Vol. I. Atlanta, 1913.

Lecky, W. E. H., A History of England in the Eighteenth Century. Second Edition. 8 vols. London, 1883.

Loskiel, G. H., History of the Mission of the United Brethren among the Indians in North America. Three Parts. 
Translated from the German by Christian I. La Trobe. London, 1794.

McCall, Hugh, The History of Georgia, Containing Sketches of the Most Remarkable Events up to the Present Day. 2 vols. Savannal, 1811 and 1816 . Also reprinted in one volume. Atlanta, 1909.

MeCrady, Elward, The History of South Carolina under the Royal Govermment. (1719-1776.) New York, 1899. Northern, W. J., Men of Mark in Georgia. 6 vols. Atlanta, 190\%. (Sketches by various writers of prominent Georgians.)

Osgood, Herbert L., The American Colonies in the Seventeenth Century. 3 vols. New York, 1904 and 1907.

Peabody, W. B. O., Life of James Oglethorpe. Boston, 1846.

Pickett, A. J., History of Alabama and Incidentally of Georgia and Mississippi, from the Earliest Period. 2 vols. Charleston, 1851.

Present State of the Nation. London, 1768.

Ramsay, David, The History of South Carolina. 2 vols. Charleston, 1809.

Raper, C. L., North Carolina, a Study in English Colonial Government. New York, 1904.

Sinith, G. G., The Story of Georgia and the Georgia People. Atlanta, 1900.

Smith, W. R., South Carolina as a Royal Province, 17191776. New York, 1903.

Spalding, Thomas, A Sketch of the Life of General James Oglethorpe. In Ga. Hist. Collec. I.

Stevens, William B., History of Georgia. 2 vols. New York, $184 \%$.

Strobel, P. A., The Salzburghers and Their Descendants, Being the History of German (Lutheran) Protestants, 
who Emigrated to Georgia in 1734, and Settled at Ebenezer, Twenty-five Miles above the City of Savannah. Baltimore, 1855.

Tyernan, L., Life and Times of Reverend John Wesley. 3 vols. London, 1871. (Gives the fullest account of John Wesley's career in Georgia.)

Life of Reverend George Whitefield. London, 1876-1877. White, George, Historical Collections of Georgia. New York, 1854.

Whitehead, John, The Life of Rev. John Wesley, M. A., with Some Account of his Ancestors and Relations; and the Life of Rev. Charles Wesley, M. A. New York, 1881. Wright, Robert, A Memoir of General James Oglethorpe, One of the Earliest Reformers of Prison Discipline in England and the Founder of Georgia in America. London, 1867. 


\section{INDEX}

Accounts of Oglethorpe, disputes about, 91-92

Acton, 282

Admiralty Courts, 122, 205

Altamaha River, $73-75$

Anderson, Adam, Trustee, 54

Appeals, 198, 200, 202, 206212, 221

Areher, Henry, 'Trustee, 52-53 Argyle, 68, 284

Assembly, Colonial, appointed, 189 ; powers, 191 ; achievements, 192-194; made permanent, 195-196

Attorney General, 24.

Augusta, 190, 224, 276, 282, 326-327, 340

Bailiffs, 139-140, 144, 200-201, 204, 212-213, 220-221

Barber, Rev. Jonathan, 291, 293, 329

"Bethany" Chureh, 341

Betliesda Orphanage, 288, et seq., 329

Bishop of London, 306-308

Board of Trade, 22-26, 77, 116-121, 123, 138, 139, 182186,253
Bochler, Rev. Peter, 330

Bolzius, Rev. John Martin, 281, 334-337

Bosomworth, Rev. Thomas, 193, 278-279, 291, 322-323

Bray, Associates of Dr., 303, 305

Bull, Col. William, 66-67

Burnside, Joln, teaeher, 284

Calwell, John, magistrate, 222 Carr (also spelled Care), Mark, 122, 205

Carteret, Lord, 53, 134, 226, 250, 252, 253, 254, 256

"Castle Builders," 60

Cateehists, 280

Causton, Thomas, magistrate, $79,115,162,163,164,218-$ 22(), 312-314

Chancellor of Exchequer, 112, 122-124, 133

Charter, motives for granting, 17-21; proeess of securing, 22-21; creates open corporation, 28 ; did Oglethorpe plan?, 60; membership and qualifieations of Trustees, 98 , et seq.; provisions as to 
executive, 137; legislative seetions, 173-174; judieiary provisions, 198-199; land regulations, 226-227

Cherokees, 276

Chiffelle, Rev., 333

Christic, Thomas, recorder, $162,163,166$

Church buildings, 338-341

Church of England, 29, 53, 294, 305-306, 307, 308, 309, $311,326,327$

C'lee vs. Minis, 209

Committees, 38 et seq., 85,

111-116,130, 189, 190

Common Council, 35-37, 38-40, $41,44,49,54,55,62,89$, 100, 101 et seq., 110-111, 113 ct seq., 155, 161, 162, $187,189,198,208,250,254$, 257 et seq., $264-265$

Conservators of peace, 201, 222, 224, 225

Constables, 200, 201

Control, imperial, 26-27

Cooper, Anthony Ashley (Earl of Shaftesbury), 51-52

Copp, Rev. Jonathan, 326327

Coram, Thomas, trustee, 60

Corporation, sce Trustees

Correspondence, Committec of, $113,115,189,190$

Coweta, treaty of, $80,85,276$

Crecks, 85, 275 et seq., 284285,323
Customs, Commissioners of, 121-122

Darien, 223, 235, 236, 280, 282, 328-329

Dearne, John, magistrate, 219 Defense, Gcorgia to be a barrier, 21 ; assumed by Crown, 77-78; invasion of Florida, 86 ; Spanish repulsed, 86

Delamotte, Charles, tcacher, 286-287

Dissenters, 53，55, 294-295, 309

Dobell, Jolın, teacher, 297-299

Driesler, Rev. Jolın Ulrich, 283, 336

Dyson, Rev., 327

Ebenezer, 73, 143, 190, 236, 276, 282, 334-336

Edueation, 208-302, see tablc of contents

Egmont, Earl of (Lord John Pereeval ), 44-46, 56, 82, 118 Executive authority, in England, 98-136, sce table of contents; in Georgia, 137172 , see table of contents

Expenses, Oglethorpe's, 69-70; Causton displaced because of, 79; dispute about, 80-82, 91-92

Ewer, Anthony, 54

Fallowficld, John, magistrate, 220 
Fees, 217

Florida, invasion of, 86

Forfeitures, 2\$t et seq.

Frederica, 73-75, 76, 147, 190, 222, 223, 224, 276, 283, 316$317,323,336,340$

French mission, 332-333

Garden, Rev. Alexander, 307308,320

“Gentleman's Magazine," 7071

Georgia, 19, 20, 21, 25, 27, 28, $31,34,42,43,44,45,47$, $48,49,50,53,55,60,64$, $65,72,73,84,85,89,90$, 103, 115, 117, 124, 126, 131, $144,151,159,167,175,180$, 189, 193, 203, 205, 208, 224, $227,239,250,251,254,269$, $270,275,286,302,303,317$, $326,334,338,341$

Gibson, Bishop Edmund, 306307

Gilbert, Robert, magistrate, 219

Gordon, Peter, magistrate, 218219

Governor, Oglethorpe not, 64; mistake of Trustees, 95-96; none appointed, 139; president takes plaee of, 154-155 Gronan, Rev. Isracl, 334-335

Habersham, James, teacher and magistrate, 169-172,
283, 287-288, 290, 291, 294, 320

Hagen, John, teacher, 286

Hales, Rev. Stephen, trustee, 50-51, 56

Harris, Franeis, president of assembly, 192

Hawkins, Dr. Thomas, magistrate, 221

Heathcote, George, trustee, 53 Heatheote, William, trustee, 53-54

Hebrews, 332

Herbert, Rev. Henry, 309

Heron, Lient.-Col., 223

Hodges, Riehard, magistrate, 218

Holt, Edward, teaeher, 300302

Hooper, Edward, trustee, 54

Hopkins, Miss Sophia (Mrs. William Williamson), 312 et seq.

Horton, Major, 222, 223

Honse of Commons, 30 ; prison investigation, 58-59; support of Georgia, 12.t et seq.; investigation of Georgia, 130 et seq., 252

Hueks, Robert, trustee, 49-50

Indians, consent to the settlement of Savannall, 6r-68; treaty of Coweta, 80, 85, 276 ; presents, 90; land grants, 275 et seq. 
Indian Trade, 76-77, 117-118, 1.5, 177-178, 316

Ingham, Rev. Benjamin, teacher, $285-286$

Instructions, to Secretary, 149 et seq.; to President and Assistants, 155 et seq.

Irene, Indian school, 284-286

"Jerusalem" church, 341

Jews, 332

Jones, Noble, surveyor and magistrate, 163, 166-167, 261,289

Jones, 'Thomas, magistrate, 220 Joubert, Peter, teacher, 299300

Judiciary, 198-225, see table of eontents; town courts, 199; county courts, 202; provincial system, 203; system suspended, 201; eourt of equity sought, 20.; admiralty courts, 205; ilppeals, 206 et seq.

Juries, 215-216

King, 23, 21, 25, 26, 227

Land system, 226-279, see table of eontents; land grants, 269-270

L'Apostre, Henry, trustee, 4647,56

Iatroche, John, trustee, 49-50

Linwers, excluded from Georgia, 213-211
Legislation, 173-197, see table of contents; initiated by Oglethorpe, 71-72; committee on laws, 174-175; Indian trade, 177-179; rum act, 179180 ; slavery law, 180-181; proposed acts, 181 ; colonial assembly, 189 et seq.

Lembke, Rev. Herman Henry, 335-336

Lloyd, Simuel, trustee, 54 London, 18，19

MeLeod, Rev. John, 328-329

Magistrates, see also Bailiffs; not installed by Ogelthorpe at first, 69 ; not governed by him, 84, 86, 87, 88

Metcalf, Rev. William, 322

Monopoly of Indian trade, 194

Moravians, 223, 284-286, 329332

More, Robert, trustee, 175

Mulberry plints, 20, 19\%, 195, $240,243,244,247$

Munch, Chretien, 34, 333

Musgrove, Mary (Mrs. Thomas Bosomworth), interpreter, $67-68,278-279$

Negro slavery, forbidden, 180181 ; allowed, 186-187

Nitsclman, Rev. David, 330

Norris, Rev. William, 319-322 
Oglethorpe, James, trustee, 5797 , see table of contents; 31 , $35,38,40,51,56,98,139$, $141,142,147,148,152,153$, $167,174,176,218,221$, 222, 257, 259, 263

Orphanage, 287 et seq.

Ortman, Christopher, teacher, 281-282

Orton, Rev. Christopher, 297, 322

Parker, Henry, magistrate and president, 163, 164-166

Pelhams, 133, 136

Pereeval, John Lord Viscount

(Earl of Egmont), trustee, 44-46, 56, 82, 118

Peryam, teacher, 290

"Political State of Great Britain," 60

Poor, state of those to be helped, 18-19

Presbyterians, 55, 328-329

President, appointed instead of governor, 153-155; powers, 155-157; powers shared with assistants, 157-158; exeeutive of whole colony, 158159; de facto powers increase, 161-162; Stephens, 167-169; Parker, 164165

Privy Council, 21, 22, 23, 24, $61,116,118,138,182,198$, 208, 209-212
Quincy, Rev. Samuel, 309-311

( uit rents, 112, 24. 245, 249

et seq.

Quorum, 105-106

Rabenhorst, Rev. Christian, 336

Recorder, 200

Register, 259-260

Religious work, 303-342, see table of contents

Roman Catholies, 309

"Rules of 1735," 232-235, 251, 265

Rum, 118, 145, 146, 175-176, 179-180, 184-185

St. Julian, James, 141

Salaries, 144-145, 159-161, 338 Salzburghers, 68, 73, 143, 144, 223, 277, 281, 282, 333-337, 341

Savannah, 66-67, 188, 189, 190, 191, 192, 223, 236, 272-273, 286, 297, 299, 311, 326, 338340

School made free, 298

Seott, Francis, 1ł1, 163

Scottish Society for Promoting Christian Knowledge, 305, 328

Secretary, office created, 148; duties, 149-152; Stephens, 167-169; Habersham, 169171 
Seward, William, assistant of

Whiteficld, 290-291

Shaftesbury, Farl of (Anthony

Ashley Cooper), trustee, 51$5 \mathcal{2}, 56$

Simms, teaeher, 290

Size of land grants, 263 et seq.

Slavery, see also Negro Slavery; 82, 146, 156, 180, 194, $195,236,245,248,296$

Sloper, William, trustee, 60

Sinith, Rev. Samuel, trustee, 47,56

Society for Promoting Christian Knowledge, 281, 303, 333

Society for Propagation of Gospel, 43, 51, 59, 112, 283, $304,305,309,323,325,326$ South Carolina, 18, 21, 22, 63, $66,67,76-77,82,86,90,93$, 117-118, 178-179, 189, 193, 264, 296, 307. 329

Spangenburg, Rev. Augustus

Gottlieb, 330

Spanish, 21, 85, 86, 95

Stephens, Thomas, maleontent, 130-131, 2.12, 252

Stephens, IVilliam, secretary and president, 87, 93, 148, $167-169,171,297,289,316$, 320

Storekeeper, an important office, $142-143,144$

Sirveyors, $261-262$
Tail male, 228-230, 232-233, 240, 242, 2.18

Thunderbolt, 68

Tithingmen, 200

Tomochichi, 68, 275, 284

Tower, Thomas, trustee, 48-49, 174

Town eourt, 199-200

Town system, 272-274

Trade, one object of the colony, 19-21

Trustees, personnel, 29-56, see table of eontents; number, 28, 31-34; bases for choosing, 29-30; attendance of members, 31-34; committee service, $38-39$; leading men, 40-54; disagreements, 55 ; critieism of, 55-56; organization, 101-102; powers as a corporation, 102; meetings, 105 et seq.; active committees, 111 et seq.; disputes with Board of Trade, 116 et seq.; disagreement with Customs officers, 121; Admiralty Board dispute, 122; appeal to Walpole and House of Commons for support, 124 et seq.; appeal to Wilmington, 130 ; defend Georgia in investigation, 130-131; later appeals to Parliament, 132133 ; surrender of charter, 134 ; estimate of work, 135136 ; attempts to legislate, 
182 et seq.; activities in Wesley, Rev. Cliarles, 285, judieial matters, 205-206; 316-317 changes in land laws, 235 et Wesley, Rev. John, 285, 286, seq.

Uehees, 277

Urlsperger, Rev. Samuel, 34, 333, 334

311 et seq.

Whitefield, Rev. George, 216, 283, 287 et seq.; 307-308, 318 et seq.

Williamson, William, 214, 313 et seq.

Vernon, James, leading trus-

Wilmington, Earl of, 130 tee, 32, 40-43, 56, 84-85, 153-154, 158, 175, 333

Vernonburgh, 43, 282

Von Reek, Baron, 333-334

Yamacraws, 275

Yemassees, 21

Von Muneh, Chreticn, 34, 333

'Zinzendorf, Count, 330

Walpole, Robert, 19, 48, 49, 50, 52, 53, 124 et seq.

Waterland, William, nagistrate, 218

"Zion" church, 341

Zouberbuhler, Rev. Bartholomew, 300, 324-326, 336, 338

Watson, Joseph, ease of, 209- Zubli, Rev. John Joachim, 324212 325,336 
H 23383 洞 




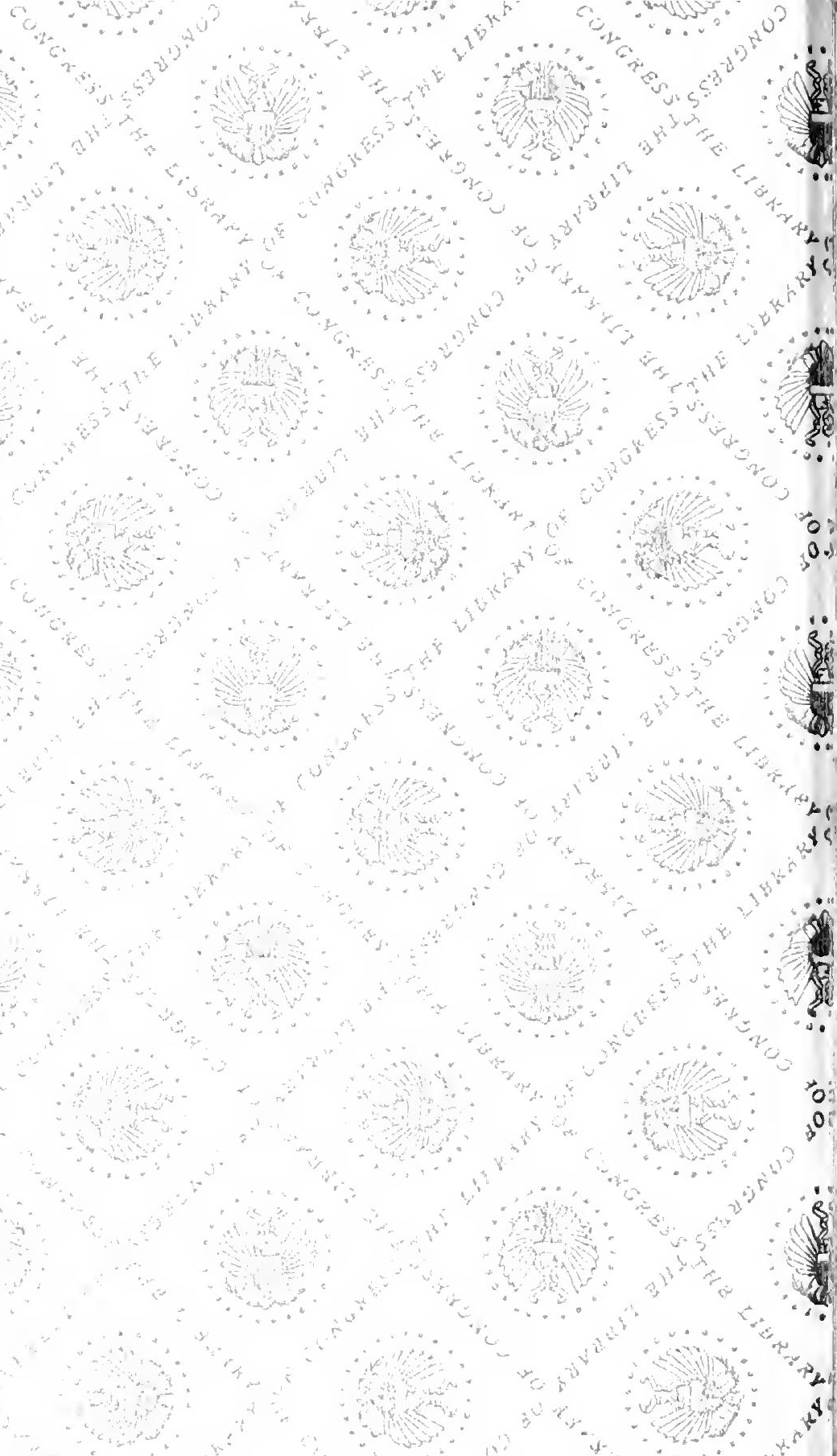




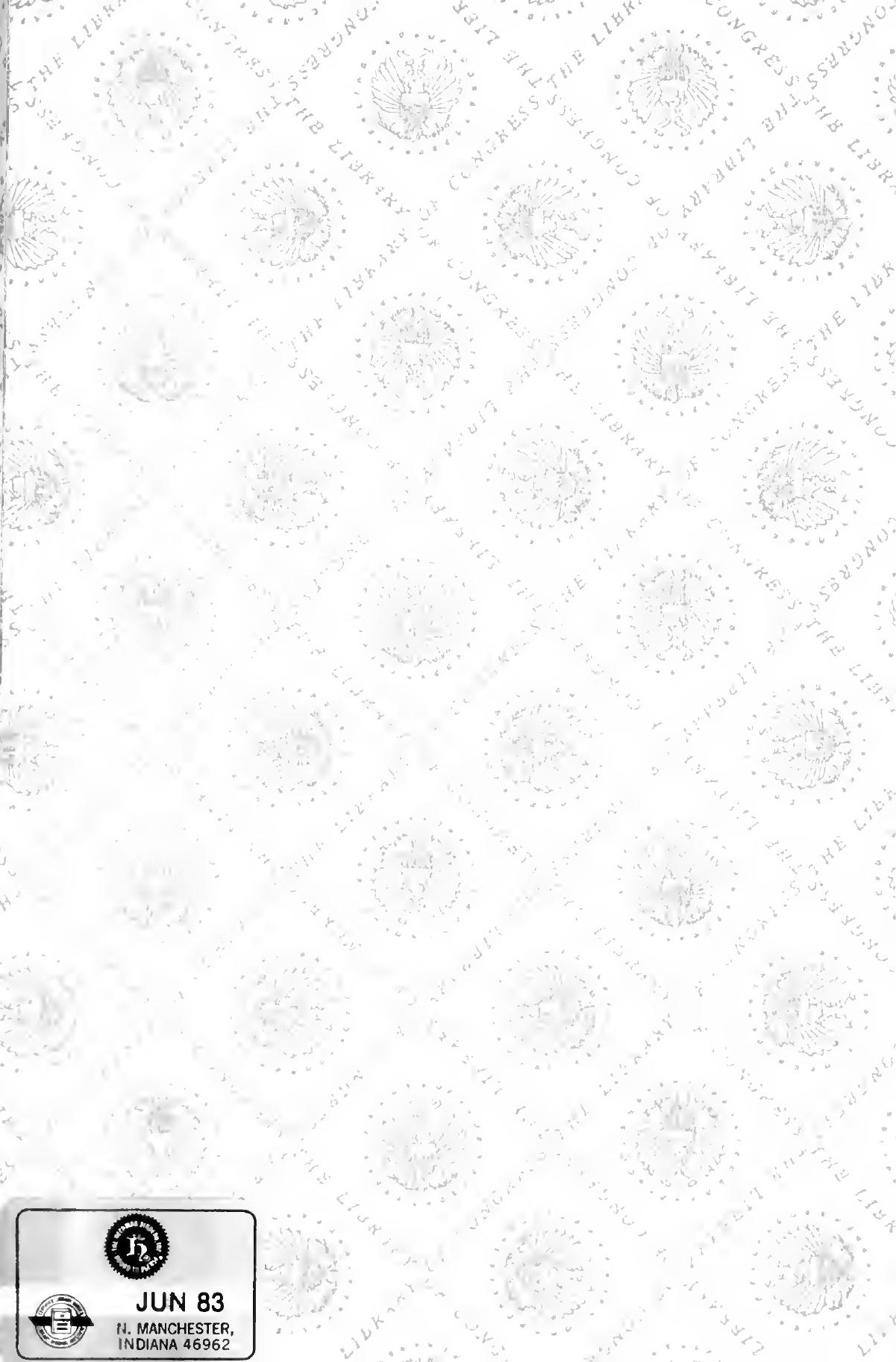


